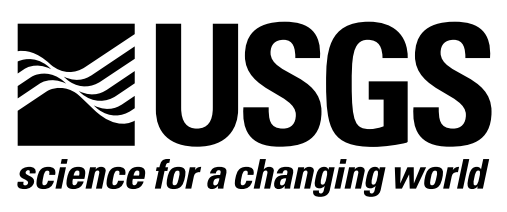

\title{
A Bibliography of Klamath Mountains Geology, California and Oregon, listing Authors from Aalto to Zucca for the Years 1849 to Mid-2003
}

Compiled by William P. Irwin

Open-File Report 03-306 (Supersedes Open-File Report 95-558)

\section{U.S. DEPARTMENT OF THE INTERIOR \\ U.S. GEOLOGICAL SURVEY}

This report is preliminary and has not been reviewed for conformity with U.S. Geological Survey editorial standards (or with the North American Stratigraphic Code). Any use of trade, product, or firm names is for descriptive purposes only and does not imply endorsement by the U.S. Government. 


\section{CONTENTS}

\section{PREFACE}

ALPHABETICAL BIBLIOGRAPHY

PHYSIOGRAPHY

FLOODS

GLACIATION 86

CAVES

MINERAL SPRINGS

WATERSHED AND GROUNDWATER INVESTIGATIONS

WILDERNESS, ROADLESS, AND RARE II AREAS

87

ROAD LOGS, FIELD GUIDES, AND RAFT TRIPS 88

GEOLOGIC MAPS

---Regional

---Quadrangle

---Thesis

AREAL GEOLOGY

STRUCTURE

---Faults

---Other, and general

METAMORPHISM

---Blueschist

---Condrey Mtn

---Other

MAGMATISM

PLUTONS

---Ashland

---Caribou Mtn

---Castle Crags

---Gibson Peak

---Greyback

---Pit River

---Russian Peak

---Wooley Creek

96

---English Peak

---Other plutons

---General features

OPHIOLITES

---Josephine

---North Fork

---Preston Peak

---Tom Martin

---Trinity

---Others, and general 99

STRATIGRAPHY

OVERLAP STRATA

- Cretaceous

---Tertiary

PALEONTOLOGY----Conodonts

---Fusulinids

---Radiolarians

---Shelly

---Vertebrates 
---Other, and general

\begin{tabular}{lc} 
TECTONICS AND REGIONAL CORRELATION & 106 \\
GEOCHEMISTRY AND PETROLOGY OF ARC AND OTHER ROCKS & 110 \\
GEOPHYSICAL RESEARCH & 112 \\
--Paleomagnetism & \\
---Aeromagnetic and related surveys & 113 \\
---Gravity & \\
---Seismic refraction & \\
--Seismicity & 114 \\
ISOTOPIC GEOCHRONOLOGY & 115 \\
MINERAL DEPOSITS-METALLIC & 117 \\
$\quad$---Chromium & \\
---Copper & \\
---Gold & \\
--Iron & 119 \\
---Lead-zinc & 120 \\
--Manganese & \\
---Massive sulfide & \\
---Mercury & \\
---Platinum & 121 \\
---Silver & 122 \\
---Other, and general & \\
--County and district reports & \\
MINERAL DEPOSITS-NONMETALLIC & \\
---Asbestos & \\
---Coal & \\
---Diamonds & \\
---Limestone & \\
---Other & \\
SPECIFIC MINERALS & \\
ENVIRONMENTAL AND ENGINEERING & \\
MISCELLANEOUS & \\
\hline
\end{tabular} 


\section{PREFACE}

This bibliography of Klamath Mountains geology was begun, although not in a systematic or comprehensive way, when, in 1953, I was assigned the task of preparing a report on the geology and mineral resources of the drainage basins of the Trinity, Klamath, and Eel Rivers in northwestern California. During the following 40 or more years, I maintained an active interest in the Klamath Mountains region and continued to collect bibliographic references to the various reports and maps of Klamath geology that came to my attention. When I retired in 1989 and became a Geologist Emeritus with the Geological Survey, I had a large amount of bibliographic material in my files. Believing that a comprehensive bibliography of a region is a valuable research tool, I have expended substantial effort to make this bibliography of the Klamath Mountains as complete as is reasonably feasible. My aim was to include all published reports and maps that pertain primarily to the Klamath Mountains, as well as all pertinent doctoral and master's theses. In addition, I included reports in which the Klamath Mountains are of significance but not the primary focus; these latter kinds are mostly reports that correlate the Klamath terranes with those of other provinces, that compare the genesis of Klamath rocks with those elsewhere, or that include the Klamath Mountains in a continental framework. Reports describing the geology of the overlap sequences such as the Great Valley sequence, Hornbrook Formation, and Tertiary sediments and volcanics are included where those rocks lie within the limits of the Klamath Mountains province, but are only selectively included where the overlap sequences are mainly peripheral to the province.

The alphabetical part of the bibliography consists of approximately 1700 entries. The list of primary references probably is virtually complete through 1994 and includes some 1995 references. The earliest reference is to James Dwight Dana in 1849. In order to restrict the size of the topical part of the bibliography to reasonable limits, each reference is listed under only one subject although many references may be applicable to two or more subjects. Titles in the topical section are abbreviated to conserve space and still retain identity.

The bibliography was compiled from a variety of sources. Some of the references have not been checked against the original publications for accuracy. Caveat emptor! I would appreciate being informed of any errors or ommissions in order that a corrected and updated version of the bibliography may be prepared. I thank Nancy Blair for assistance in verifying some of the references, and thank Mary Donato and Robert Brown for helpful suggestions regarding the topical part of the bibliography.

William P. Irwin Menlo Park, California June 27, 1995

Since the first version of this bibliography was released in 1995, the total number of entries has increased from approximately 1700 to 1937, which indicates a continued high interest in the geology of the Klamath Mountains province. The total number of entries includes 73 Ph.D. theses and 123 Masters theses representing 26 universities.

William P. Irwin Menlo Park, California July 31, 2003 
ALPHABETICAL BIBLIOGRAPHY

Aalto, K.R., 1988, Sedimentology of the Montgomery Creek Formation, Shasta County, California: California Geology, v. 41, no. 11, p. 254-260.

---1989, Preface, in Aalto, K.R., and Harper, G.D., leaders, Geologic evolution of the northernmost Coast Ranges and western Klamath Mountains, California: 28th International Geological Congress, Field Trip Guidebook T308, p. v-vi, American Geophysical Union, Washington, D. C.,

Aalto, K.R., and Harper, G.D. (leaders), 1989, Geologic evolution of the northernmost Coast Ranges and western Klamath Mountains, California: 28th International Geological Congress, Field Trip Guidebook T308, 82 p., American Geophysical Union, Washington, D. C.

Aalto, K. R., Irwin, W.P., and Kelsey, H.M., 1988, Reconnaissance geologic map of the Pilot Creek quadrangle, Humboldt and Trinity Counties, California: U. S. Geological Survey, Open-File Report 88-363, scale 1:62,500.

Aalto, K.R., Moley, K., Knudsen, K.L., Stone, L., Phillips, P.A., and Renne, P.R., 1991, Sediment provenance and Cenozoic tectonic evolution of the central and western Klamath Mountains and northernmost Coast Ranges, California: Geological Society of America, Abstracts with Programs, v, 23, no. 5, p. 137.

Aalto, K.R., Moley, K., and Stone, L., 1995, Neogene paleogeography and tectonics of northwestern California, in Fritsche, A. E., ed, Cenozoic paleogeography of the western United States--II: Society of Economic Paleontologists and Mineralogists, Pacific Section, v. 75, p. 162-180.

Abbot, H.L., Lt., 1857, Report upon explorations for a railroad route from the Sacramento Valley to the Columbia River, in Reports of explorations and surveys to ascertain the most practicable and economical route for a railroad from the Mississippi River to the Pacific Ocean: U.S. War Department, v. 6, part 1, p. 1-134.

Achache, J., Cox, A., and O'Hare, S., 1982, Paleomagnetism of the Devonian Kennett Limestone and the rotation of the eastern Klamath Mountains, California: Earth and Planetary Science Letters, v. 61, p. 365-380.

Adrian, B.M., Smith, D.B., Vaughn, R.B., and McDougal, C.M., 1983, Chemical analyses for samples of rock, stream sediments, and nonmagnetic heavy-mineral concentrates, Condrey Mountain Roadless Area, Siskiyou County, California: U.S. Geological Survey, Open-File Report 83-0812, 12 p., index map scale 1:50,000.

---1983, Results of chemical analyses for samples of stream sediments and nonmagnetic heavy-mineral concentrates, Orleans Mountain Roadless Area, Humboldt and Siskiyou Counties, California: U.S. Geological Survey, Open-File Report 83-0811, 10 p., index map scale 1:50,000.

Albers, J.P., 1953, Geology and ore deposits of the Afterthought mine, Shasta County, California: California Division of Mines, Special Report 29, $18 \mathrm{p}$.

---1958, Geology and ore deposits of the East Shasta copper-zinc district, Shasta County, California: Dissertation Abstracts, v. 18, no. 5, p. 1765.

---1959, Soda metasomatism in the East-Shasta copper-zinc district northern California: Geological Society of India Journal, v. 1, p. 31-43.

---1961, Gold deposits in the French Gulch-Deadwood district, Shasta and Trinity Counties, California, in Geological Survey research, 1961: U.S. Geological Survey Professional Paper 424-C, p. C1-C4.

---1964, Geology of the French Gulch quadrangle, Shasta and Trinity Counties, California: U.S. Geological Survey Bulletin 1141-J, p. J1-J70.

---1964, Jurassic "oroclinal" folding and related strike-slip faulting in the western United States Cordillera: Geological Society of America Special Paper 76, p. 4.

---1965, Economic geology of the French Gulch quadrangle, Shasta and Trinity Counties, California: California Division of Mines and Geology Special Report 85, 43 p.

---1966, Economic deposits of the Klamath Mountains, in Geology of northern California: California Division of Mines and Geology Bulletin 190, p. 51-62.

---1980, Metallic mineral deposits in California's tectonic framework, in Lee-Moreno, J. L., (ed.), Metalogenesis en Latinoamerica: International Union of Geological Sciences, no. 5, p. 55-74.

---1981, A lithologic-tectonic framework for the metallogenic provinces of California: Economic Geology, v. 76, no. 4, p. 765-790.

---1984, Introduction, in Geological and geophysical studies of chromite deposits in the Josephine Peridotite, northwestern California and southwestern Oregon: U.S. Geological Survey Bulletin 
1546 A-D, p. 1-5.

---1984, Geology and chromite in the Low Plateau area, Del Norte County, California: U. S. Geological Survey Bulletin 1546 B, p. 38-52.

---1985, Introduction, in A special issue devoted to massive sulfide deposits, West Shasta district, California: Economic Geology, v. 80, no. 8, p. 2067-2071.

---1985, Geology of the Brick Flat massive sulfide body, Iron Mountain cluster, West Shasta district, California: Economic Geology, v. 80, no. 8, p. 2092-2099.

Albers, J.P., and Bain, J.H.C., 1985, Regional setting and new information on some critical geologic features of the West Shasta district, California: Economic Geology, v. 80, no. 8, p. 2072-2091.

Albers, J.P., Evans, J.G., Griscom, A., Wynn, J.P., and Hasbrouck, W.P., 1984, Geological and geophysical studies of chromite deposits in the Josephine Peridotite, northwestern California and southwestern Oregon: U.S. Geological Survey Bulletin B 1546 A-D, 86 p.

Albers, J.P., Kistler, R.W., and Kwak, L., 1981, The Mule Mountain Stock, an early Middle Devonian pluton in Northern California: Isochron/west, no. 31, p. 17.

Albers, J.P., Kinkel, A.R., Jr., Drake, A.A., and Irwin, W.P., 1964, Geology of the French Gulch quadrangle, California: U.S. Geological Survey Geologic Quadrangle Map GQ-336, scale 1:62,500.

Albers, J.P., and Robertson, J.F., 1952, New evidence establishes Permian age for the Dekkas andesite, Shasta County, California: Geological Society of America Bulletin, v. 63, no. 12, pt. 2, p. 1319.

---1961, Geology and ore deposits of East Shasta copper-zinc district, Shasta County, California: U.S. Geological Survey Professional Paper 338, 107 p.

Alexander, R.J., 1992, Oceanic faulting and hydrothermal alteration within the crustal sequence of the Josephine ophiolite, northwest California and southwest Oregon: Albany, State University of New York, Ph.D. dissertation, 324 p.

Alexander, R.J., and Harper, G.D., 1990, Subseafloor hydrothermal alteration in the basal sheeted dike complex of the Josephine ophiolite during extensional faulting and tilting at the paleospreading axis: Eos (American Geophysical Union Trans.), v. 71, no. 43, p.1647-1648.

---1992, The Josephine ophiolite: an ancient analogue for slow- to intermediate-spreading oceanic ridges, in Parson, L.M., Murton, B.J., and Browning, P. eds., Ophiolites and their modern oceanic analogues: Geological Society Special Publication, London, No, 60, p. 3-38.

Alexander, R.J., Harper, G.D., and Bowman, J.R., 1993, Oceanic faulting and fault-controlled subseafloor hydrothermal alteration in the sheeted dike complex of the Josephine ophiolite: Journal of Geophysical Research, v. 98, no. B6, p.9731-9759.

Allen, C.M., 1981, Intrusive relations and petrography of the Slinkard pluton, central Klamath Mountains, California: Eugene, Oregon University, M.S. thesis, 120 p.

Allen, C.M., Barnes, C.G., Kays, M.A., and Saleeby, J.B., 1982, Comagmatic nature of the Wooley Creek Batholith and the Slinkard Pluton and age constraints on tectonic and metamorphic events in the western Paleozoic and Triassic belt, Klamath Mountains, northern California: Geological Society of America, Abstracts with Programs, v. 14, no. 4, p. 145.

Allen, J.E., 1938, Chromite deposits in Oregon: Oregon Department of Geology and Mineral Industries Bulletin 9, $71 \mathrm{p}$.

---1941, Geologic investigation of the chromite deposits of California: California Journal of Mines and Geology, v. 37, no. 1, p. 101-167.

---1945, A vanadium-bearing black-sand deposit of middle Miocene age, in central Curry County, Oregon: Geological Society of Oregon Country Geological News Letter, v. 11, no. 4, p. 21.

Alpers, C.N., Maenz, Cathy, Nordstrom, D.K., Erd, R.C., and Thompson, J.M., 1991, Storage of metals and acidity by iron-sulfate minerals asssociated with extremely acid mine waters, Iron Mountain, California: Geological Society of America, Abstracts with Programs, v. 23, no. 5, p. 382.

Alpers, C.N., Nordstrom, D. K., Verosub, K. L., and Helm, C. M., 1999, Paleomagnetic reversal in Iron Mountain gossan provides limits on long- term, premining flux rates: Geological Society of America, Abstracrs with Programs, v. 31, no. 6, p. 33.

Alt, D.D., and Hyndman, D.W., 1975, Roadside geology of northern California: Mountain Press Publishing Co., Missoula, Montana, 244 p.

---2000, Roadside geology of northern and central California: Mountain Press Publishing Co., Missoula. Montana, $370 \mathrm{p}$.

Anderson, F.M., 1895, Some Cretaceous beds of Rogue River Valley, Oregon: Journal of Geology, no. 3, p. 455-468.

---1901, Neocene basins of the Klamath Mountains: Geological Society of America Bulletin, v. 12, p. 
500-501; also Journal of Geology, no. 9, p. 75-76 (1901) and American Geologist, no. 27, p. 131 (1901). ---1902, Cretaceous deposits of the Pacific Coast: California Academy of Science Proceedings 3d series, Geology, v. 2, no. 1, p. 43-47.

---1902, Ore deposits of Shasta County (California): Science, ns, v. 15, p. 412.

---1902, The physiographic features of the Klamath Mountains: Journal of Geology, v. 10, p. 144-159.

---1903, Physiography and geology of the Siskiyou Range: Journal of Geology, no. 11, p. 100; also Engineering and Mining Journal, no. 75, p. 154 (1903).

---1931, Upper Cretaceous (Chico) deposits in Siskiyou County, California: Mining in California, v. 27, no. 1, p. 11-14.

---1938, Lower Cretaceous deposits in California and Oregon: Geological Society of America Special Paper 16, $339 \mathrm{p}$.

---1958, Upper Cretaceous of the Pacific Coast: Geological Society of America Memoir 71, 378 p.

Ando, C.J., 1977, Disrupted ophiolitic sequence in the south central Klamath Mountains, California: Geological Society of America, Abstracts with Programs, v. 9, no. 4, p. 380.

---1979, Structural and petrologic analysis of the North Fork terrane, central Klamath Mountains, California: Los Angeles, Southern California University, Ph.D. dissertation, 197 p.

---1979, Anomalous disrupted ophiolite in the central Klamath Mountains, California: Geological Association of Canada, Fourth Annual Meeting, Program Abstract 4, p. 36.

Ando, C., Cashman, P., and Davis, G.A., 1976, Structural and stratigraphic equivalence of the Stuart Fork, North Fork, and Hayfork terranes, central Klamath Mountains, California: Geological Society of America, Cordilleran Section, 72nd Annual Meeting, Program, Pullman, Washington, v. 8, no. 3, p. 349-350.

---1977, Geologic summary and road log of portions of the central Klamath Mountains, California, in Guidebook to the geology of the Klamath Mountains, northern California: Geological Society of America, Cordilleran Section, 73rd Annual Meeting, Sacramento, California, Guidebook, p. 134-156.

Ando, C.J., Irwin, W.P., Jones, D.L., and Saleeby, J.B., 1983, The ophiolitic North Fork terrane in the Salmon River region, central Klamath Mountains, California: Geological Society of America Bulletin, v. 94, no. 2, p. 236-252.

Ando, C.J., and Saleeby, J.B., 1980, Implications of a Permo-Triassic age for North Fork ophiolitic rocks in the central Klamath Mountains, California : Geological Society of America, Abstracts with Programs, v. 12, no. 3, p. 94.

Anonymous, 1871, Diamonds in Trinity County, California: Mining and Science Press, v. 22, March 24, p. 140.

---1982, Gasquet Mountain project reserves confirmed by study: E \& MJ, Engineering and Mining Journal, v. 183 , no. 3, p. 11.

---1982, Promisory outlook at Gasquet Mountain: Mining Journal (London), 299(7671), p. 144.

---1982, Gasquet Mountain, a US metal laterite project: Mining Magazine, v. 147, no. 3, p. 170-171.

Appling, R.N., Jr., 1958, Manganese deposits of southwestern Oregon: U.S. Bureau of Mines Report Investigation 5369, $56 \mathrm{p}$.

Armstrong, R.L., 1975, Cenozoic igneous history of the Cordillera north of $42^{\circ}$ N.: Geological Society of America, Abstracts with Programs, v. 7, no. 7, p. 981.

Aubin, W.L., and Lee, D.R., 1996, Petrology and geochemistry of a portion of the Trinity ulramafic sheet near Kangaroo Lake, Klamath Mountains, northwestern California: Geological Society of Americqa, Abstracts with Programs, v. 28, no. 5, p. 44

Aubouin, J., Blanchet, R., Roure, F., and Tardy, M., 1986, Traits généraux des cordillères de l'Ouest des Etats-Unis: Bulletin de la Société géologique de France, v. 8, t II, no. 5, p. 741-754.

Aubury, L.E., 1902, The copper resources of California: California State Mining Bureau Bulletin 23, 282 p.

---1903, The quicksilver resources of California: California State Mining Bureau Bulletin 27, 273 p.

---1906, Structural and industrial materials of California: California State Mining Bureau Bulletin 38, $412 \mathrm{p}$.

---1908, The copper resources of California: California State Mining Bureau Bulletin 50, 366 p.

Aubury, L.E., and others, 1908, The copper resources of California: California State Mining Bureau Bulletin 50, $366 \mathrm{p}$.

Aubury, L.E., Winston, W.B., and Janin, C., 1910, Gold dredging in California: California State Mining Bureau Bulletin 57, 305 p. 
Aune, Q.A., 1970, A trip to Castle Crags: California Division of Mines and Geology, Mineral Information Service, v. 23, no. 7, p. 139-144.

---1970, Glaciation in Mt. Shasta-Castle Crags: California Division of Mines and Geology, Mineral Information Service, v. 23, no. 7, p. 145-148.

Ave-Lallement, H.G., and Oldow, J.S., 1988, Early Mesozoic southward migration of Cordilleran transpressional terranes: Tectonics, v. 7, p. 1057-1076.

Averill, C.V., 1931, Preliminary report on economic geology of the Shasta quadrangle: California Division of Mines, 27th Report State Mineralogist, no. 1, p. 2-65.

---1931, The Mountain Copper Company, Ltd., cyanide treatment of gossan: California State Mining Bureau, 27th Report State Mineralogist, chap. 2, p. 129-138.

---1933, Trinity County:California Division of Mines Report, p 1-19.

---1933, Gold deposits of the Redding and Weaverville quadrangles: California Journal of Mines and Geology, v. 29, nos. 1-2, p. 2-73.

---1935, Mines and mineral resources of Siskiyou County California: California Journal of Mines and Geology, v. 31, no. 3, p. 255-338.

---1935, The Shasta County copper belt, California, in Copper resources of the world: International Geologic Congress, 16th, Washington, p. 237-240.

---1938, Gold dredging in Shasta, Siskiyou, and Trinity Counties: California Journal of Mines and Geology, v. 34, p. 96-126.

---1938, The Mountain Copper Company, Ltd., cyanide treatment of gossan: California Journal of Mines and Geology, v. 34, p. 312-330.

---1939, Mineral resources of Shasta County: California Journal of Mines and Geology, v. 35, no. 2, p. 108-191.

---1940, Economic geology of California and southern Oregon: Geological Society of America Bulletin, v. 5l, no. 12, pt. 2, p. 2017.

---1941, Dragline dredging in Siskiyou County: California State Mining Bureau, 37th Report State Mineralogist, p. 328-331.

---1941, Mineral resources of Humboldt County: California State Mining Bureau, 37th Report State Mineralogist, p. 499-528.

---1941, Mineral resources of Trinity County: California State Mining Bureau, 37th Report State Mineralogist, p. 8-89.

---1946, Placer mining for gold in California: California Division of Mines Bulletin 35, 377 p.

Bailey, L.E., 1980, Geology of Scott Summit, Klamath Mountains, northern California: Eugene, University of Oregon, M.S. thesis, 106 p.

Bald, J.F., 1991, Castle Crags wilderness, a climbers guide: Alpentech Press, Redding, California, 65 p.

Baldwin, E.M., 1964, Geology of Oregon, 2d edition: Eugene, University of Oregon Cooperative Book Store, $165 \mathrm{p}$.

---1976, Geology of Oregon: Kendall-Hunt Publication, Revised edition, 147 p.

---1964, Thrust faulting in the Roseburg area, Oregon: Ore Bin, v. 26, no. 10, p. 176-184.

---1969, Thrust faulting along the lower Rogue River, Klamath Mountains, Oregon: Geological Society of America Bulletin, v. 80, no. 10, p. 2047-2052.

---1980, Pioneer geologists of southwestern Oregon: Geological Society of America, Abstracts with Programs, v. 12, no. 3, p. 95.

Baldwin, E.M., and Hess, P. D., 1971, Geology of the Powers quadrangle Oregon: Oregon Department of Geology and Mineral Industries, Geologic Map Series, GMS-5.

Baldwin, E.M., Lent, R.L., and Hess, P.D., 1968, Post-Nevadan Mesozoic geology of the northern Klamath Mountains, Oregon: Geological Society of America, Program, Annual Meeting, Tucson, Arizona, p. 32-33.

Baldwin, E. M., and Lent, R.L., 1969, Post-Nevadan Mesozoic geology of the northern Klamath Mountain, Oregon: Geological Society of America Special Paper 121, p. 480-481.

---1972, Eocene emplacement of the Colebrooke thrust plate, Oregon: Geological Society of America, Cordilleran Section, 68th Annual Meeting, Program, Honolulu, v. 4, no. 3, p. 125.

Baldwin, E.M., and Rud, J.O., 1972, Thrusting of the Rogue Formation near Marial on the lower Rogue River, Oregon: Ore Bin, v. 34, no. 4, p. 57-66.

Baldwin, K.S., 1993, Geomorphic surfaces in the northwestern Klamath Mountains, California and Oregon, in Field guide and abstracts: NAGT-FWS Fall 1993 Meeting, Bridge Bay Resort, CA, p. A5. 
Baldwin, K.S., 1993, Management of coarse sediment and its effects on riparian habitat in the central Klamath Mountains, in Field guide and abstracts: NAGT-FWS Fall 1993 Meeting, Bridge Bay Resort, CA, p. A6.

Baldwin, K.S., and De La Fuente, J.A., 1987, Large Quaternary landslide deposits in the central Klamath and south Cascade Mountains, California: Geological Society of America, Abstracts with Programs, v. 19, no. 7, p. 578.

---1989, Multiple remnant planar landforms, Klamath Mountains, CA: Geological society of America, Abstracts with Programs, v. 21, no. 5, p. 53.

Baldwin, K.S., and Ricks, C.L., 1993, Geomorphic surfaces in the northwestern Klamath Mountains, California and Oregon: Geological Society of America, Abstracts with Programs, v. 25. No. 5, p. 5.

Balsley, J.R., Jr., Bromery, R.W., and Remington, E.W., 1960, Aeromagnetic map of the Kerby and part of the Grants Pass quadrangles, Josephine and Curry Counties, Oregon: U.S. Geological Survey Geophysics Investigations Map P-197, scale, 1:96,000.

Barker, F., Millard, H.T., Jr., and Knight, R.J., 1977, Reconnaissance geochemistry of Devonian island-arc and intrusive rocks, West Shasta District, California: Geological Society of America, Cordilleran Section, 73rd Annual Meeting, Program, Sacramento, Calif., v. 9, no. 4, p. 385.

---1979, Reconnaissance geochemistry of Devonian island-arc and intrusive rocks, West Shasta District, California, in Trondhjemites, dacites, and related rocks, Barker, Fred, ed.: Elsevier Scientific Publications Company, Netherlands, p. 531-545.

Barnard, J.B., Page, NJ. J., Blakely, R.J., Ziemianski, W.P., Banister, C. A., and Giusso, J.R., 1981, Map showing distribution of serpentine minerals, density, and magnetic susceptibility of rocks from the Kalmiopsis Wilderness, southwestern Oregon: U.S. Geological Survey Miscellaneous Field Studies Map MF-1240-B, scale 1:62,000.

Barnes, C.G., 1982, Geology and petrology of the Wooley Creek batholith Klamath Mountains, California: Eugene, Oregon University, Ph.D. dissertation, 214 p.

---1983, Petrology and upward zonation of the Wooley Creek batholith, Klamath Mountains, California: Journal of Petrology, v. 24, pt. 4, p. 495-537.

---1987, Mineralogy of the Wooley Creek batholith, Slinkard pluton, and related dikes, Klamath Mountains, northern California: American Mineralogist, v. 72, p. 879-901.

---1991, Tilted plutons in the Klamath Mountains--another look: Geological Society of America, Abstracts with Programs, v. 23, no. 2, p. 4-5.

---1991, Mid Jurassic and Early Cretaceous plutonism, Klamath Mountains: Geological Society of America, Abstracts with Programs, v. 23, no. 2, p. 5.

Barnes, C.G., and Allen, C.M., 1984, Open- and closed-system fractionation in the Wooley Creek batholith and Slinkard pluton magmatic system, Klamath Mountains, northern California: Geological Society of America, Abstracts with Programs, v. 16, no. 6, p. 437.

Barnes, C.G., Allen, C.M., and Brigham, R.H., 1987, Isotopic heterogeneity in a tilted plutonic system, Klamath Mountains, California: Geology, v. 15, no. 6, p. 523-527.

Barnes, C.G., Allen, C.M., Hoover, J.D., and Brigham, R.H., 1990, Magmatic components of a tilted plutonic system, Klamath Mountains, California, in Anderson, J. L., ed., The nature and origin of Cordilleran magmatism: Geological Society of America Memoir 174, 331-346.

Barnes, C.G., Allen, C.M., and Saleeby, J.B., 1986, Open- and closed-system characteristics of a tilted plutonic system, Klamath Mountains, California: Journal of Geophysical Research, v. 91, no. B6, p. 6073-6090.

Barnes, C.G., Barnes, M.A., and Kistler, R.W., 1989, Geochemistry of Caribou pluton, Klamath Mountains, CA: Geological Society of America, Abstracts with Programs, v. 21, no. 5, p. 53-54.

---1992, Petrology of the Caribou Mountain pluton, Klamath Mountains, California: Journal of Petrology, v. 33, Pt. 1, p. 95-124.

Barnes, C.G., Donato, M.,M., Barnes, M.A., Yule, J.D., Hacker, B.R., and Helper, M.A., 1995, Geochemical compositions of metavolcanic and metasedimentary rocks, western Jurassic and western Paleozoic and Triassic belts, Klamath Mountains, Oregon and California: U.S. Geological Survey, Open-File Report 95-227-A, 63 p.

Barnes, C.G., Donato, M.M., and Tomlinson, S.L., 1993, Correlation of the Applegate Group in the Oregon Klamath Mountains with terranes of the western Paleozoic and Triassic belt in California: Geological Society of America, Abstracts with Programs, v. 25, No. 5, p. 6.

Barnes, C.G., Jachens, R.C., and Donato, M.M., 1982, Evidence for basal detachment of the western Paleozoic and Triassic belt, northern Klamath Mountains, California: Geological Society of 
America, Abstracts with Programs, v. 14, no. 4, p. 147.

Barnes, C.G., and Johnson, K.S., 1992, The Grayback pluton: Late Jurassic backarc(?) magmatism in the Klamath Mountains, Oregon: Geological Society of America, Abstracts with Programs, v. 24, no. 5, p. 5.

Barnes, C.G., Johnson, K., Barnes, M.A., Prestvik, T., and Kistler, R.W., 1992, The Grayback Pluton; magmatism in a Jurassic back-arc environment, Klamath Mountains, Oregon, in Brown, P.E., and Chappell, B.W., eds., The second Hutton symposium on the origin of granites and related rocks: Geological Society of America Special Paper 272, p. 485.

Barnes, C.G., Johnson, K., Barnes, M.A., Prestvik, T., Kistler, R.W., and Sundvoll, B., 1995, The Grayback pluton: Magmatism in a back-arc environment, Klamath Mountains, Oregon: Journal of Petrology, v. 36, p. 397-415.

Barnes, C.G., Johnson, K., and Walton, C., 1996, Middle Jurassic to Cretaceous magmatism in the Klamath and Blue Mountains, Oregon and California: Geological Society of America, Abstracts with Programs, v. 28, no. 5, p. 46.

Barnes, C.G., Karlsson, H.R., Johnson, K., and Kistler, R.W., 1992, Isotopic variation of pre- and postNevadan plutons, (Middle Jurassic-Early Cretaceous) Klamath Mountains: Geological Society of America, Abstracts with Programs, v. 24, no. 5, p. 6.

Barnes, C.G., Petersen, S.W., Kistler, R.W., Murray, R., and Kays, M.A., 1996, Source and tectonic implications of tonalite-trondhjemite magmatism in the Klamath Mounains: Contributions to Mineralogy and Petrology, v. 123, p. 40-60.

Barnes, C.G., Petersen, S.W., Kistler, R.W., Prestvik, T., and Sundvoll, B., 1992, Tectonic implications of isotopic variation among Jurassic and Early Cretaceous plutons, Klamath Mountains: Geological Society of America Bulletin, v. 104, p. 117-126.

Barnes, C.G., Petersen, S.W., Murray, R., and Kays, M.A., 1994, Origin of tonalite and trondhjemite by crustal melting, Klamath Mountains, California and Oregon: Geological Society of America, Abstracts with Programs, v. 26, no. 7, p. 292.

Barnes, C.G., Prestvik, T., and Barnes, M.A., 1989, Geochemistry of the Greyback pluton, Klamath Mountains, OR: Geological Society of America, Abstracts with Programs, v. 21, no. 5, p. 53.

Barnes, C.G., and Rice, J.M., 1983, Tilted plutons in the Klamath Mountains: Geological Society of America Abstracts with Programs, v. 15, no. 5, p. 314.

Barnes, C.G., Rice, J.M., and Gribble, R.F., 1986, Tilted plutons in the Klamath Mountains of California and Oregon: Journal of Geophysical Research, v. 91, no. B9, p. 6059-6071.

Barnes, C.G., Snoke, A.W., Frost, C.D., 2002, Jurassic arc magmatism in the Klamath Mountains, California-Oregon: Geological Society of America, Abstracts with Programs, v. 34, no. 5, p. A-22.

Barnes, C.G., Snoke, A.W., Frost, C.D., and Bushey, J.C., 2002, Petrology of the Bear Mountsain intrusice complex, Klamath Mountains, Cslifornia: exploting the roots of an oceanic-arc plutonic suite: Geological Society of America, Abstracts with Programs, v. 34, no. 6, p. 270.

Barnes, C.G., Snoke, A.W., and Mars, V., 1999, Shoshonitic magmatism during contracturaal deformation, Klamath Mountains, northern California: Geological Society of America, Abstracts with Programs, v. 31, no. 6, p. A-36.

Barnes, I., Irwin, W.P., and Gibson, H.A., 1975, Geologic map showing springs rich in carbon dioxide or chloride in California: U.S. Geological Survey, Water Resources Investigation, Open-file Map.

Barnes, M.D., 1983, Geology of Big Foot cave, Marble Mountains Wilderness Area, California, in Thomas, R. G., ed., Proceedings of the annual meeting of the National Speleological Society: National Speleological Society Bulletin, v. 45, no. 1.

Barnett, J.C., 1982, Palynology and paleoecology of the Weaverville Formation (Tertiary), northwestern California: Seattle, University of Washington, M. S. thesis, 118 p.

Barrow, W., and Metcalf, R.V., 2002, Central metamorphic terrane, northern California: Geochemical evidence of a mid-ocean ridge origin: Geological Society of America, Abstracts with Programs, v. 34, no., 5, p. A-43.

Barrows, A.G., 1969, An inverted, gradational sequence of basic metamorphic rocks along the Scott River, Siskiyou County, California: Geological Society of America, Cordilleran Section, 65th Annual Meeting, Program, Eugene, Oregon, pt. 3, p. 3-4.

---1969, The petrogenesis of an Alpine ultramafic complex in the Klamath Mountains, Siskiyou County, California: Geological Society of America, Cordilleran Section, 65th Annual Meeting, Program, Eugene, Oregon, pt. 3, p. 4.

---1969, Geology of the Hamburg-McGuffy Creek area, Siskiyou County, California, and petrology for 
the Tom Martin ultramafic complex: Los Angeles, California University, Ph.D. dissertation, 354 p.; also Dissertation Abstracts, v. 30, no. 11, p. 5096-5097.

Bartley, R.C., 1955, Geology of the East Evans Creek area, Trail quadrangle, Oregon: Corvallis, Oregon State University, M. Sc. thesis, 81 p.

---1972, An unusual gold occurrence from Douglas County: Ore Bin, v. 34, no. 3, p. 52-53, Illus. (includes sketch map).

Bayne, G.W., 1950, An auxiliary method of geologic mapping in the Galice quadrangle, Oregon: Seattle, University of Washington, M. S. thesis, $62 \mathrm{p}$.

Beaulieu, J.D., and Hughes, P.W., 1977, Land use geology of central Jackson County, Oregon: Oregon Department of Geology and Mineral Industries Bulletin 94, 87 p.

Beck, M.E., Jr., 1992, Tectonic significance of paleomagnetic results for the western conterminous United States, in Burchfiel, B.C., Lipman, P.W., and Zoback, M.L., eds., The Geology of North America Volume G-3, The Cordilleran Orogen: Conterminous U.S.: Geological Society of America, Boulder, Colorado, p. 683-697.

Bedrossian, T.L., 1991, Timber harvesting in granitic terrain, Grass Valley Creek, Trinity County, California: California Geology, v. 44, no. 11, p. 250-255.

Belasky, Paul, 1994, Determination of Permian longitude of Stikinia, Wrangellia, and Eastern Klamath terranes based on coral biogeography: Geological Society of America, Abstracts with Programs, v. 26, no. 7, p. 57.

Belasky, Paul, and Runnegar, Bruce, 1994, Permian longitudes of Wrangellia, Stikinia, and Eastern Klamath terranes based on coral biogeography; Geology, v. 22, no. 12, p. 1095-1098.

Belasky, P., Stevens, C.A., and Hanger,R., 1999, Early Permian location of western North American terranes: Geological Society of America, Abstracts with Programs, v. 31, no. 6, p. 37.

Bence, A.E., 1984, REE systematics of West Shasta metavolcanic rocks: Petrogenesis and hydrothermal alteration: Spokane, Washington, Northwest Mining Association, 90th Annual Convention, Abstracts, p. 60.

Bence, A.E., and Taylor, B.E., 1985, Rare earth element systematics of West Shasta metavolcanic rocks: Petrogenesis and hydrothermal alteration: Economic Geology, v. 80, no. 8, p. 2164-2176.

Benson, W.T., 1963, Pine Flat and Diamond Flat nickel-bearing latarite deposits, Del Norte County, California: U.S. Bureau of Mines Report Investigation 6206, 19 p.

Berry, W.B.N., and Boucot, A.J., 1970, Correlation of North American Silurian rocks: Geological Society of America Special Paper 102:, 153 p.

Berry, W.B.N., Lindsley-Griffin, N., Potter, A.W., and Rohr, D.M., 1973, Early Middle Ordovician graptolites from the eastern Klamath Mountains, Siskiyou County, California: Geological Society of America, Cordilleran Section, 69th Annual Meeting, Program, Portland, Oregon, v. 5, no. 1, p. 11.

Bergstrom, S.M., Potter, A.W., Porter, R.W., Boucot, A.J., and Rohr, D.M., 1980, Biostratigraphic and biogeographic significance of Ordovician conodonts in the eastern Klamath Mountains, northern California: Geological Society of America, Abstracts with Programs, v. 12, no. 5, p. 219.

Bero, D.A., 1980, Petrology of the Heather Lake Pluton, Klamath Mountains, California: Fresno, California State University, Master's thesis, $86 \mathrm{p}$.

Bestland, E.A., Blackwell, D.L.S., and Kays, M.A., 1987, Stratigraphy of an amphibolite facies thrustslice in the Marble Mountains terrane, Klamath Mountains, California: Geological Society of America Abstracts with Programs, v. 19, no. 6, p. 359.

Bevis, K.A., 1989, Relative dating techniques and the glacial geology of the upper Clear Creek watershed, Siskiyou Mountains, northern California: Arcata, Humboldt State University, M.Sc. thesis.

Bird, J.M., and Bassett, W.A., 1980, Terrestrial osmium-iridium-ruthenium alloys; evidence for a deep mantle history: Eos (American Geophysical Union Trans.), v. 61, no. 17, p. 375.

Bird, J.M., Meibom, A., Frei, R., Nagler, T.F., 1999, Osmium and lead isotopes of rare OsIrRu minerals: derivation from the core-mantle boundary region?: Earth and Planetary Science Letters, v. 170, p. 83-92.

Black, G.L., 1979, Structural geology of the southeast quarter of the Dutchman Butte quadrangle, Oregon: Portland, Oregon State University, M.S. thesis, 108 p.

Black, J., 1967, Handbook for underwater prospectors: Tarzana, California, Ames Publishing Company, $97 \mathrm{p}$.

Blackwelder, E., 1914, A summary of the orogenic epochs in the geologic history of North America: 
Journal of Geology, v. 22, p. 633-654.

Blair, M.L., 1983, Geology of the lower Grider Creek ridge area, Siskiyou County, California: Reno, University of Nevada, M. Sc. thesis.

Blair, W.N., 1978, Radiolarians from Mesozoic rocks in western Oregon, in Geological Survey Research 1978: U. S. Geological Survey Professional Paper 1100, p. 78.

Blair, W.N., Wong, Albert, Moring, B.C., Barnard, J.B., Page, N.J., and Gray, Floyd, 1981, Reconnaissance geologic map of parts of the Gold Hill, Ruch, Medford, and Talent 15' quadrangles, southwestern Oregon: U.S. Geological Survey Open-File Report 81-1076, scale 1:62,500.

Blake, M.C., Jr., 1965, Structure and petrology of low-grade metamorphic rocks, blueschist facies, Yolla Bolly area, northern California: Stanford, California, Stanford University, Ph.D. dissertation, $123 \mathrm{p}$.

---1984, Tectonstratigraphic terranes in southwestern Oregon, in Nilsen, T.H., ed., Geology of the Upper Cretaceous Hornbrook Formation, Oregon and California: Society of Economic Paleontologists and Mineralogists, Pacific Section, Book no. 42, p. 159-165.

Blake, M.C., Jr., Engebretson, D.C., Jayko, A.S., and Jones, D.L., 1985, Tectonostratigraphic terranes in southwest Oregon, in Howell, G. D., ed., Tectonostratigraphic terranes of the circum-Pacific region: Circum-Pacific Council for Energy and Mineral Resources, Earth Science Series No. 1, p. 147-157

Blake, M.C., Jr., Harwood, D.S., Helly, E.J., Irwin, W.P., Jayko, A.S., and Jones, D.L., 1984, Preliminary geologic map of the Red Bluff 100,000 quadrangle, California: U.S. Geological Survey, Open-File Map 84-105, scale 1:100,000, with text, 22 p.

---1999, Geologic map of the Red Bluff 30' X 60' quadrangle, California: U.S. Geological Survey, Geologic Investigations Map I-2542, scale 1:100,000, with 15 page text.

Blake, M.C., Jr., Howell, D.G., and Jones, D.L., 1982, Preliminary tectonostratigraphic terrane map of California: U. S. Geological Survey, Open-File Report 82-593, 3 sheets, with text, $10 \mathrm{p}$

Blake, M.C., Jr., and Jayko, A.S., 1986, Tectonic evolution of northwest California and southwest Oregon: Bulletin de la Societe geologique de France, v. 8, II, p. 921-930.

Blake, M.C., Jr., Jayko, A.S., McLaughlin, R.J, and Underwood, M.B., 1985, Tectonostratigraphic terranes of northern California in Howell, D.G., ed., Earth Sciences Series, Circumpacific Council for Energy and Mineral Resources, v. 1, p. 159-171..

Blake, M.C., Jr., and Jones, D.L., 1977, Tectonics of the Yolla Bolly junction and its significance to the plate tectonic history of northern California: Geological Society of America, Cordilleran Section, 73rd Annual Meeting, Program, Sacramento, Calif., v. 9, no. 4, p. 391.

---1977, Plate tectonic history of the Yollo Bolly junction, northern California: Geological Society of America, Cordilleran section, 73rd. Annual Meeting, Sacramento, California, guidebook, $21 \mathrm{p}$.

Blake, M.C., Jr., and Peters, T.J., 1983, Mineral resource potential map of the Weaver Bally Roadless Area, Trinity County, California: U.S. Geological Survey Miscellaneous Field Studies Map MF-1657-A, scale 1:48,000, with text 7 p.

---1984, Weaver Bally Roadless Area, California, in Wilderness Mineral Potential, S. P. Marsh and others, eds.: U.S. Geological Survey Professional Paper 1300, v. 1, p. 407-409.

Blake, M.C., Jr., and Wentworth, C. M., 1992, Preliminary metamorphic facies map of western California and southwestern Oregon: Geological Society of America Abstracts with Programs, v. 24, no. 7, p. A292.

Blakely, R.J., 1986, Maps showing aeromagnetic data and interpretation of the Medford $1^{\circ}$ by $2^{\circ}$ quadrangle, Oregon-California: U. S. Geological Survey, Miscellaneous Field Studies Map MF-1383-B, scale 1:250,000.

Blakely, R.J., Jachens, R.C., Simpson, R.W., and Couch, R.W., 1985, Tectonic setting of the southern Cascade Range as interpreted from its magnetic and gravity fields: Geological Society of America Bulletin, v. 96, no. 1, p. 43-48.

Blank, H.R., Jr., 1964, Regional gravity survey in southwestern Oregon: Preliminary results: Geological Society of America, Program, Annual Meeting, Seattle, Washington, p. 21.

---1965, Regional gravity survey in southwestern Oregon--Preliminary results: Geological Society of America Special Paper 82, p. 241.

---1966, General features of the Bouguer gravity field in southwestern Oregon, in Geological Survey research 1966: U.S. Geological Survey Professional Paper 550-C, p. C113-C119.

Block, R.H., 1982, The Whitney survey of California, 1860-1874; a study of environmental science and exploration: Los Angeles, University of California, Ph. D. dissertation, 480 p. 
Blome, C.D., and Irwin, W.P., 1983, Tectonic significance of Late Paleozoic to Jurassic radiolarians in the North Fork terrane, Klamath Mountains, California, in C. H. Stevens, ed., Pre-Jurassic rocks in western North American suspect terranes: Society of Economic Paleontologists and Mineralogists, Pacific Section, p. 77-89.

Blome, C.D., and Reed, K.M., 1995, Radiolarian biostratigraphy of the Quinn River Formation, Black Rock terrane, north-central Nevada: Correlations with eastern Klamath terrane geology: Micropaleontology, v. 41, no. 1, p.49-68.

Boalich, E.S., 1918, Manganese and chromium: California State Mining Bureau, Preliminary Report 3, $32 \mathrm{p}$.

Boardman, J.J., 1985, Petrology of the Salmon Mountain stock, Klamath Mountains, California: Lubbock, Texas Tech University, M. Sc. thesis.

Bogen, N.L., 1984, Paleomagnetism of metavolcanic rocks of the upper Galice Formation, western Klamath Mountains, California and Oregon: Geological Society of America, Abstracts with Programs, v. 16, no. 6, p. 448.

---1986, Paleomagnetism of the Upper Jurassic Galice Formation, southwestern Oregon: Evidence for differential rotation of the eastern and western Klamath Mountains: Geology, v. 14, p. 335-338.

---1986, Reply, in Comments and Reply on "Paleomagnetism of the Upper Jurassic Galice Formation, southwestern Oregon: Evidence for differential rotation of the eastern and western Klamath Mountains": Geology, v. 14, no. 12, p. 1050-1051.

Bogdanov, N.A., and Dobretsov, N.L., 1987, The ophiolites of California and Oregon: Geotectonics, v. 21, no. 5, p. 472-479.

Boggs, S., Jr., and Baldwin, E.M., 1970, Distribution of placer gold in the Sixes River, southwestern Oregon; a preliminary report: U.S. Geological Survey Bulletin, no. 1312-I, 27 p.

Boggs, S., Jr., and Swanson, F.J., 1970, Unusual slump structure from Cretaceous(?) sandstones, northern Klamath Mountains region, Oregon: Ore Bin, v. 32, no. 2, p. 25-29.

Bond, G.C., and DeVay, J.C., 1979, Petrology and provenance of a pre-Upper Devonian quartzose flysch in the northern Sierra Nevada, California: implications to the tectonic history of the Sierra Nevada Block: Geological Society of America, Abstracts with Programs,v. 11, no. 3, p. 70-71.

Borns, D.J., 1980, Blueschist metamorphism of the Yreka-Fort Jones area, Klamath Mountains, northern California: Seattle, Washington University, Ph.D dissertation, 167 p.

---1980, Progressive deformation within a coherent blueschist terrane, Yreka-Fort Jones area, Klamath Mountains, California: Geological Society of America, Abstracts with Programs, v. 12, no. 3, p. 98.

---1981, Blueschist metamorphism of the Yreka-Ft. Jones area, Klamath Mountains, California: Geological Society of America, Abstracats with Programs, v.13, p. 413.

---1984, Ecologites in the Stuart Fork terrane, Klamath Mountains, California: Geologica Society of America, Abstracts with Programs, v. 16, no. 5, p. 271.

Bosted, Peter, 1990, California cave exploration and mapping in the 1980's: California Caver, v. 40, no. 1 , p. 14-20.

---1989, Exstream cave: California Caver, v. 39, no. 1, p. 16-17.

Bosted, Peter, and Richardson, Bob: 1989, Stairstep Dome cave: California Caver, v. 39, no. 3, p. 70-71.

Bostwick, D.A., and Nestell, M.K., 1966, Tethyan fusulinid fauna of central Oregon: Geological Society of America, Program, Annual Meeting, San Francisco, California, p. 22.

Botinelly, T., Siems, D.F., and Sanzolone, R.F., 1985, Trace elements in disseminated sulfides, magnetite, and massive sulfides, West Shasta district, California: Economic Geology, v. 80, no. 8, p. 2196-2205.

Botto, R.I., and Morrison, G.H., 1976, Josephinite; a unique nickel-iron: American Journal of Science, v. 276, no. 3, p. 241-274.

Boucot, A.J., 1970, Pre-Carboniferous history of the eastern Klamath Mountains in California, in Frenkel, R.E., and others, eds., Proceedings of the Oregon Academy of Science 28th annual meeting: Oregon Academy of Science, Proceedings, v. 6, p. 18.

---1971, , Aenigmastrophia, new genus, a difficult Silurian brachiopod: Smithsonian Contiributions to Paleobiology Number 3, v., p. 155-158.

---1973, Pre-late Middle Devonian biostratigraphy of the eastern Klamath belt, northern California: Geological Society of America, Abstracts with Programs, v. 5, p. 15.

Boucot, A.J., Dean, W.T., Martinsson, A., Potter, A., Rexroad, C., Rohr, D., Savage, N.M., and Wright, A.J., 1973, Biogeographic relations of the pre-Late Middle Devonian of the eastern Klamath Belt, northern California: Geological Society of America, Abstracts with Programs, v. 5, no. 1, p. 14. 
Boucot, A.J., Dunkle, D.H., Potter, A., Savage, N.M., and Rohr, D., 1974, Middle Devonian orogeny in western North America?: a fish and other fossils: Journal of Geology, v. 82, p. 691-708.

Boucot, A.J., and Potter, A.W., 1977, Middle Devonian orogeny and biogeo-graphical relations in areas along the North American Pacific rim, in Murphy, M. A., Berry, W. B. N., and Sandberg, C. A., eds., Western North America: Devonian: California University, Riverside Campus Museum Contribution, v. 4, p. 210-219.

Boudier, F., Le Sueur, E., and Nicolas, A., 1989, Structure of an atypical ophiolite: The Trinity complex, eastern Klamath Mountains, California: Geological Society of America Bulletin, v. 101, p. 820833.

Boudier, F., Nicolas, A., and Lesueur, E., 1983, The Trinity plagioclase lherzolite (northern California): A preliminary structural survey, in Ophiolites: Oceanic tectonics and metamorphism: Ofioliti, Second annual meeting held by the working group on Mediterranean ophiolites, Florence, Italy, Supplement to Volume 8, p. 15.

Boyle, A.C., 1914, The geology and ore deposits of the Bully Hill mining district, California: American Institute of Mining Engineers Bulletin 85, p. 57-105.

---1915, The geology and ore deposits of the Bully Hill mining district, California: American Institute of Mining Engineers Transaction 48, p. 67-117.

Boyle, J.M., 1974, A history of some communities along highway 299: Geological Society of Sacramento, Annual Field Trip Guidebook, p. 59-61.

Bradley, W.W., 1918, Quicksilver resources of California, with a section on metallurgy and ore-dressing: California State Mining Bureau Bulletin 78, 389 p.

Bradley, W.W., and others, 1918, Manganese and chromium in California: California State Mining Bureau Bulletin 76, 247 p.

Brewer, W.A., III, 1954, The geology of a portion of the China Mountain quadrangle, California: Berkeley, California University, M.A. thesis, $47 \mathrm{p}$.

Brindley, G.W., 1969, Unit cell of magadiite in air, in vacuo, and under other conditions: American Mineralogist, v. 54, no. 11-12, p. 1583-1591.

Brooks, H.C., 1963, Quicksilver in Oregon: Oregon Department of Geology and Mineral Industries Bulletin 55, $223 \mathrm{p}$.

Brooks, H.C., and Ramp, L., 1968, Gold and silver in Oregon: Oregon Department of Geology and Mineral Industries Bulletin 61, 337 p.

Brouxel, M., 1984, Les Basaltes de Trinity et leur complexe filonien temoins de l'existence d'un bassin marginal au Devonien dans les Klamath orientales (Californie, Etats- Unis): D.E.A., Université de Nancy I, $40 \mathrm{p}$.

---1988, Geochemical consequences of flow differentiation in a multiple injection dike (Trinity Ophiolite, N. Califronia): Geological Society of America Abstracts with Programs, v. 20, no. 7, p. 157.

Brouxel, M., and Lapierre, H., 1984, La serie basaltique de Trinity (Klamaths orientales, Nord Californie) temoin de l'existence d'un bassin marginal au Devonian moyen: Comptes Rendus de l'Academie des Sciences de Paris, v. 299, p. 457-462.

---1985, Un bassin marginal devonien dans les Klamath orientales (Californie du Nord, Etats Unis): le cortege ophiolitique de Trinity: Ofioliti, v. 10, p. 181-202.

---1988, Geochemical study of an early Paleozoic island-arc-back-arc basin system. Part 1: The Trinity Ophiolite (northern California): Geological Society of America Bulletin, v. 100, no. 7, p. 11111119.

Brouxel, M., Lapierre, H., and Allarede, F., 1984, A marginal basin of Devonian age in the Klamath Mountains (northern California): The Trinity ophiolite complex, in Ophiolites through time: Ofioliti, Abstracts, 3rd Annual Meeting, November 13-15, 1984, Nancy, Supplement to v. 9, p. 12.

Brouxel, M., Lapierre, H., Michard, A., and Albarede, F., 1987, The deep layers of a Paleozoic arc: Geochemistry of the Copley-Balaklala volcanics (California): Earth and Planetary Science Letters, v. 85 , p. 386-400.

---1988, Geochemical study of an early Paleozoic island-arc-back-arc basin system. Part 2: Eastern Klamath, early to middle Paleozoic island-arc volcanic rocks (northern California): Geological Society of America Bulletin, v. 100, no. 7, p. 1120-1130.

Brouxel, M., Lapierre, H., and Zimmermann, J.L., 1989, Upper Jurassic mafic magmatic rocks of the eastern Klamath Mountains, northern California: Remnant of a volcanic arc built on young continental crust: Geology, v. 17, no. 3, p. 273-276. 
Brouxel, M., Lecuyer, C., and Lapierre, H, 1989, Diversity of magma types in a lower Paleozoic island arc-marginal basin system (eastern Klamath Mountains, California, U.S.A.): Chemical Geology, v. 77, p. 251-274.

Brown, G.C., 1916, Mines and Mineral Resources, pt. 6, The Counties of Shasta, Siskiyou, and Trinity: California State Mining Bureau, 14th Report State Mineralogist, p. 747-925.

Brown, R.E., 1942, Some manganese in the southern Oregon coastal region: Oregon Department of Geology and Mineral Industries Short Paper 9, 6 p.

Brown, W.W., 1965, Geochemistry of selected soil profiles developed on ultra-mafic rocks, Del Norte County, California: Stanford, California, Stanford University, Ph.D. dissertation, 185 p.; also Dissertation Abstracts, v. 26, no. 11, p. 6642-6643.

Bruckno, B., 1997, Geochemistry of the Trinity ophiolite and the Trinity Complex: Lincoln, University of Nebraska, M.S. thesis, $97 \mathrm{p}$

Bruemmer, J.L., and Kays, M.A., 1965, Gravity models for peridotite injection and local metamorphism along north-northeast-trending zones of tectonism, southwest Oregon: Geological Society of America Special Paper 82, p. 242-243.

Bryant, H.C., 1914, Teeth of a cestraciont shark from the upper Triassic of northern California: California University, Department of Geological Science Bulletin 8, p. 27-30.

---1914, Vertebrate fauna of the Triassic limestones at Cow Creek, Shasta County, California: Geological Society of America Bulletin, v. 25, p. 155.

Buer, Koll, and James, Steve, 1979, South Fork Trinity River watershed erosion investigation: California Department of Water Resources, northern district, $83 \mathrm{p}$.

Buer, K.Y., Scott, R.G., and James, S., 1979, South Fork Trinity River watershed investigation, north coastal California: Geological Society of America, Abstracts with Programs, v. 11, no. 7, p. 395-396.

Burchfiel, B.C., Cowan, D.S., and Davis, G.A., 1992, Tectonic overview of the Cordilleran orogen in the western United States, in Burchfiel, B.C., Lipman, P.W., and Zoback, M.L., eds., The Geology of North America Volume G-3, The Cordilleran Orogen: Conterminous U.S.: Geological Society of America, Boulder, Colorado, p. 407-479.

Burchfiel, B.C., and Davis, G.A., 1972, Structural framework and evolution of the southern part of the cordilleran orogen, western United States: American Journal of Science, v. 272, no. 2, p. 97-118.

---1975, Nature and controls of cordilleran orogenesis, western United States: extensions of an earlier synthesis: American Journal of Science, v. 275-A, p. 363-396.

---1981, Triassic and Jurassic tectonic evolution of the Klamath Mountains-Sierra Nevada geologic terrane, in The geotectonic development of California, Rubey Volume I, Ernst, W. G., ed., Prentice-Hall, Inc., p. 50-70.

Burton, W.C., 1982, Geology of the Scott Bar Mountains, northern California: Eugene, University of Oregon, M.S. thesis, 120 p.

Busby-Spera, C.J., Mattinson, J.M., Riggs, N.R., and Schermer, E.R., 1990, The Triassic-Jurassic magmatic arc in the Mojave-Sonoran Deserts and the Sierran-Klamath region; Similarities and differences in paleogeographic evolution, in Harwood, D.S., and Miller, M.M., eds., Paleozoic and early Mesozoic paleogeographic relations; Sierra Nevada, Klamath Mountains, and related terranes; Geological Society of America Special Paper 255, p. 325-337.

Butler, G.M., and Mitchell, G.J., 1916, Preliminary survey of the geology and mineral resources of Curry County, Oregon: Oregon Bureau of Mines and Geology, Mineral Resources of Oregon, v. 2, no. 2, 134 p.

Calderwood, A.R., 1991, No suspect terranes; the case against paleomagnetic data: Geological Society of America, Abstracts with Programs, v. 23, no. 5, p. 136.

Calderwood, A.R., and Armstrong, R.L., 1990, Geochronologic and tectonic constraints on the onset and mechanism of Neogene uplift of the Klamath Mountains, northern California: Eos (American Geophysical Union Trans.), v. 71, no. 43, p. 1633.

California Department of Natural Resources, Division of Mines, 1954, Nickel in California: California Division of Mines Mineral Information Service, v. 7, no. 11, p. 1-5.

California Department of Water Resources, 1964, Crustal strain and fault movement investigation--Faults and earthquake epicenters in California: California Department of Water Resources Bulletin 116-2, 96 p.

---1964, Ewing Project--Reconnaissance study: Sacramento, California, California Department of Water Resources Northern Branch, 56 p. 
California Division of Mines, 1957, California mineral production, 1956: California Division of Mines Mineral Information Service, v. 10, no. 2.

Campbell, D.F., 1906, The iron ore of Shasta County, California: Mining and Science Press 93, p. 603.

---1907, The copper of Shasta County, California: Mining and Science Press, v. 94, p. 28-30, 55-58.

---1908, La Grange hydraulic mine: Mining and Scientific Press, v. 97, no. 15, p. 491-493.

Campos, Ch., Charvet, J., LaPierre, H. 1992, The Eastern Klamath Mountains (N. California): an example of the development and amalgamation of a Lower to Mid-Paleozoic "suspect terrane" and its relation to the North American margin: Geochronique, no. 42 p. 46-47.

Cannat, M., 1983, Cinématique de charriages ophiolitiques (Klamath, Semail, Groix) et Convergence océanique: Nantes, France, Université de Nantes, Thèse de 3ème Cycle, Doctoral, 170 p.

---1985, Tectonics of the Seiad massif, northern Klamath Mountains, California: Geological Society of America Bulletin, v. 96, no. 1, p. 15-26.

Cannat, M., and Boudier, F., 1985, Structural study of intra-oceanic thrusting in the Klamath Mountains, northern California: implications on accretion geometry: Tectonics, v. 4, no. 5, p. 435-452.

---1985, Correction to "Structural study of intra-oceanic thrusting in the Klamath Mountain, northern California: implications on accretion geometry": Tectonics, v. 4, 6, p. 597-601.

---1986, Reply: Tectonics, v. 5, p. 693-695.

---1986, Chaarriages infra-ophiolitiques et convergence oceanique dans les Klamath Mountains (Californie du Nord): Bulletin de la Societe geologique de France, v. 8, II, p. 1001-1005.

Cannat, M., and Lecuyer, C., 1991, Epithermal magma chambers in the Trinity peridotite, northern California: Tectonophysics, v. 186, no. 3-4, p. 313-328.

Carlson, C.A., Page, N.J., and Carlson, R.R., 1986, Map showing distribution of the platinum-group elements and gold in rocks from the western half of the Medford and part of the adjacent Coos Bay $1^{\circ}$ by 2 quadrangles, southwestern Oregon: U. S. Geological Survey Miscellaneous Field Studies Map MF-1832, 2 sheets, scale 1:250,000.

Carlson, C.A., Page, N.J., Grimes, D.J., and Leinz, R.W., 1982, Map showing geochemical characteristics of rock sample from the Kalmiopsis Wilderness, southwestern Oregon: U. S. Geological Survey Miscellaneous Field Studies Map MF-1240-C, scale 1:62,500.

Carlton, R.W., 1972, Stratigraphy, Petrology, and Mineralogy of the Colestine Formation (Eocene) in southwest Oregon and northern California: Corvallis, Oregon State University, Ph.D. dissertation, $230 \mathrm{p}$.

Carter, B.A., and Quick, J.E., 1987, The ultramafic rocks at Eunice Bluff, Trinity Peridotite, Klamath Mountains, California, in Hill, M.L., ed., Centennial Field Guide Volume 1, Cordilleran Section of the Geological Society of America: Geological Society of America, Boulder, Colorado, p. 283-288.

Casey, W.H., 1979, Geology and geochemistry of mineralization and alteration in the central portion of the West Shasta Cu-Zn district, Shasta County, California: Davis, University of California, M. S. thesis, $149 \mathrm{p}$.

Casey, W. H., and Taylor, B. E., 1978, Stable isotopic investigation of hydrothermal ore fluids in massive sulfide deposits of the West Shasta Cu-Zn district, California, in Silberman, M. L., and others, eds., Proceedings of the Symposium on mineral deposits of the Pacific Northwest: U.S. Geological Survey Open-File Report, no. 81-0355, p. 261-277.

---1982, Oxygen, hydrogen, and sulfur isotope geochemistry of a portion of the West Shasta Cu-Zn district, California: Economic Geology, v. 77, no. 1, p. 38-49.

Cashman, P.H., 1974, Cross-section of a portion of the western Paleozoic and Triassic subprovince, Salmon River, Klamath Mountains, California, in Geologic guide to the southern Klamath Mountain: Geological Society of Sacramento, Annual Field Trip Guidebook, p. 62-68.

---1974, Melange terrane in the western Paleozoic and Triassic subprovince, Klamath Mountains, California: Geological Society of America Cordilleran Sec., 70th Annual Meeting, Program, Las Vegas, Nevada, v. 6, no. 3, p. 153.

---1978, Volcaniclastic sequence in the central Klamath Mountains, Humboldt and Trinity Counties, California: Geological Society of America, Cordilleran Section, 74th Annual Meeting, Program, Tempe, Arizona, v. 10, no. 3, p. 99.

---1979, Geology of the Forks of Salmon area, Klamath Mountains, California: Los Angeles, Southern California University Ph.D dissertation, 240 p.

Cashman, P.H., and others, 1982, Geology of Coyote Peak [15'] quadrangle, Humboldt County, California, DMG OFR 82-15, scale 1:62,500: Open File Report California Department of 
Conservation Division of Mines and Geology.

Cashman, S.M., 1977, Correlation of the Duzel Formation with the central metamorphic belt, northeastern Klamath Mountains, California: Geological Society of America, Cordilleran Sec., 73rd Annual Meeting, Program, Sacramento, California, v. 9, no. 4, p. 398.

---1977, Structure and petrology of part of the Duzel Formation and related rocks in the Klamath Mountains southwest of Yreka, California: Seattle, University of Washington, Ph.D dissertation, $94 \mathrm{p}$.

---1980, Devonian metamorphic event in the northeastern Klamath Mountains, California: Geological Society of America Bulletin, pt. I, v. 91, no. 8, p. 453-459.

---1988, Finite-strain patterns of Nevadan deformation, western Klamath Mountains, California: Geology, v. 16, no. 9, p. 839-843.

Cashman, S.M., and Cashman, K.V., 1996, Evidence for eposidic slip preserved in textures of finegrained fault rocks, La Grange fault, California: Geological Society of America, Abstracts with Programs, v. 28, no. 7, p. 244-245.

Cashman, S.M., Cashman, P.H., and Wagner, D.L., 1983, Low-angle thrusting of the Rattlesnake Creek terrane, western Klamath Mountains, California: Geological Society of America, Abstracts with Programs, v. 15, no. 5, p. 314.

Cashman, S.M., and Elder, D.R., 1993, Tertiary detachment faulting and associated mineralization on the La Grange fault, Klamath Mountains, California, in Field guide and abstracts: NAGT-FWS 1993 Fall Meeting, Bridge Bay Resort, CA, p. A9.

---1993, Tertiary detachment faulting and associated mineralization on the La Grange fault, Klamath Mountains, California (abstract): EOS Transactions, American Geophysical Union, 1993 Fall Meeting, v. 74, no. 43, p. 577-578.

---1996, The La Grange fault revisited: Evidence for regionally-extensive detachment faulting, Klamath Mountains, California: Geological Society of America, Abstracts with Programs, v. 28, no. 5, p. 55.

Cashman, S,M., Elder, D., and Goldstein, H., 1999, Detachment faulting in the Klamath Mountains, northern California in Hirt, W. H., ed., Across the Klamath/Cascade Frontier: National Association of Geoscience Teachers, Far Western Section, Fall Field Conference, Sept. 17-19, Guidebook, $87 \mathrm{p}$.

Castro, Jon, 1993, Petrology of the Eltapom ophiolite remnant, Rattlesnake Creek terrane, northern California, in Field guide and abstracts: NAGT-FWS 1993 Meeting, Bridge Bay Resort, CA, p. A10.

Cater, F.W., Jr., and Wells, F.G., 1953, Geology and mineral resources of the Gasquet quadrangle, California-Oregon: U.S. Geological Survey Bulletin 995-C, p. 79-133.

Chace, F.M., Cumberlidge, J.T., and Cameron, W.L., 1969, Applied geology at the Nickel Mountain mine, Riddle, Oregon: Economic Geology, v. 64, no. 1, p. 1-16.

Chambers, J.M., 1983, The geology and structural petrology of ultramafic and associated rocks in the northeast Marble Mountains Wilderness, Klamath Mountains, California: Eugene, University of Oregon, M. S. thesis, $149 \mathrm{p}$.

Champ, J.G., Jr., 1969, Geology of the northern part of the Dixonville quadrangle, Oregon: Eugene, University of Oregon, M. S. thesis, $86 \mathrm{p}$.

Chapman, R.H., 1966, The gravity field in northern California, in Geology of northern California: California Division of Mines and Geology Bulletin 190, p. 395-405.

Charlton, D., 1977, Preliminary report on the petrology of the Ironside Mountain batholith, Klamath Mountains, northern California: Geological Society of America, Abstracts with Programs, v. 9, no. 4, p. 399.

---1978, An upward-coarsening volcaniclastic submarine fan constructed on the Rattlesnake Creek ophiolite, Ironside Mountain quadrangle, Trinity County, Klamath Mountains, California: Geological Society of America, Abstracts with Programs, v. 10, no. 3, p. 99.

---1979, Geology of part of the Ironside Mountain quadrangle, northern California, Klamath Mountains: Santa Barbara, California University, Ph.D. dissertation, 542 p.

Charvet, J., Lapierre, H., and Campos, C., 1989, The effects of a mid-Paleozoic tectonic event (Antler orogeny) in the eastern Klamath Mountains (N. California, U.S.A.). Geodynamioc implications: C. R. Acad. Sci. Paris, t. 308, Serie II, p. 1629-1635.

Charvet, J., Lapierre, H., Mascle, G., Lecuyer, C., and Brouxel, M., 1987, New evidence on the Paleozoic polyphased tectonogenesis in the eastern Klamath Mountains (N California, USA): Terra Cognita 
Journal of European Union of Geoscience, v. 7, no. 2-3, p. 181.

Charvet, J., Lapierre, H., Rouer, O., Coulon, C., Campos, C., Martin, P., and Lecuyer, C., 1990, Tectonomagmatic evolution of Paleozoic and early Mesozoic rocks in the eastern Klamath Mountains, California, and the Blue Mountains, eastern Oregon-western Idaho, in Harwood, D.S., and Miller, M.M., eds., Paleozoic and early Mesozoic paleogeographic relations; Sierra Nevada, Klamath Mountains, and related terranes; Geological Society of America Special Paper 255, p. 255-276.

Chase, A.W., 1873, On the lower Klamath River mines; remarkable gravel deposits of the lower Klamath: American Journal of Science, series 3, no. 6, p. 56-59.

Chase, G.W., 1988, Aeromagnetic map of the Weed quadrangle, California: California Division of Mines and Geology, scale 1:250,000.

Chen, J.H., and Shaw, H.F., 1982, Pb-Nd-Sr isotopic studies of California ophiolites: Geological Society of America, Abstracts with Programs, v. 14, no. 7, p. 462.

Chernosky, J.V., 1969, Metasomatic zoning at Tamarack Lake, Trinity County, California: Madison, Wisconsin University M.S. thesis, 55 p.

---1975, Metasomatic zoning at Tamarack Lake, Trinity County, California: Eos (American Geophysical Union Trans.), v. 56, no. 12, p. 1081.

Churkin, M., Jr., 1958, Silurian stratigraphy of part of the Yreka and China Mountain quadrangles, Siskiyou County, California: Berkeley, University of California, M.A. thesis, 85 p.

---1960, Silurian strata of the Klamath Mountains, California: American Journal of Science, v. 258, no. 4 , p. 258-273.

---1961, Silurian trilobites from the Klamath Mountains, California: Journal of Paleontology, v. 35, no. 1, p. $168-175$.

---1965, First occurrence of graptolites in the Klamath Mountains, California, in Geological Survey research, 1965: U.S. Geological Survey Professional Paper 525-C, p. C72-C73.

---1974, Paleozoic marginal ocean basin-volcanic arc systems in the cordilleran foldbelt, in Dott, R. J., and Shaver, R. H., eds., Modern and ancient geosynclinal sedimentation: Society of Economic Paleontologists and Mineralogists, Special Publication no. 19, p. 174-192.

Churkin, M., Jr., and Eberlein, G.D., 1977, Ancient borderland terranes of the North America Cordillera; correlation and micro-plate tectonics: Geological Society of America Bulletin, v. 88, no. 6, p. 769-786.

Churkin, M., Jr., and Langenheim, R.L., Jr., 1960, Silurian strata of the Klamath Mountains, California: American Journal of Science, v. 258, no. 4, p. 258-273.

Clarke, F.W., 1888, Some nickel ores from Oregon: American Journal of Science, series 3, no. 35, p. 483-488

Clark, W.B., 1970, Gold districts of California: California Division of Mines and Geology Bulletin 193, $186 \mathrm{p}$.

---1974, Gold in the Klamath Mountains, in Geologic guide to the southern Klamath Mountains: Geological Society of Sacramento, Annual Field Trip Guidebook, p. 54-57.

Coleman, R.G., 1967, Low-temperature reaction zones in alpine ultramafic rocks of California, Oregon, and Washington: U.S. Geological Survey Bulletin 1247, 49 p.

---1972,The Colebrooke Schist of southwestern Oregon and its relation to the tectonic evolution of the region: U.S. Geological Survey Bulletin 1339, 61 p.

---1973, Metamorphism and plate tectonics in southwest Oregon: Geological Society of America, Abstracts with Programs, v. 5, no. 1, p. 25.

---1986, Ophiolites and accretion of the North American cordillera: Bulletin de la Societe geologique de France, v. 8, II, p. 961-968.

Coleman, R.G., Garcia, M., and Anglin, C., 1977, The amphibolite of Briggs Creek: A tectonic slice of metamorphosed oceanic crust in southwestern Oregon: Geological Society of America, Cordilleran Section, 72nd Annual Meeting, Program, Pullman, Washington, v. 8, no. 3, p. 363.

Coleman, R.G., and Helper, M.D., 1983, Significance of the Condrey Mountain dome in the evolution of the Klamath Mountains, California and Oregon: Geological Society of America Bulletin, Abstracts with Programs, v. 15, no. 5, p. 294.

Coleman, R.G., Helper, M.D., and Donato, M.M., 1983, Geologic map of the Condrey Mountain Roadless Area, Siskiyou County, California: U.S. Geological Survey, Miscellaneous Field Studies Map MF-1540-A, scale 1:50,000.

Coleman, R.G., and Irwin, W.P., 1974, Ophiolites and ancient continental margins, in The geology of continental margins: Springer-Verlag, New York, Inc., p. 921-931. 
Coleman , R.G., and Irwin, W.P., eds., 1977, North American Ophiolites: Oregon Department of Geology and Mineral Industries, Bulletin 95, 183 p., 3 plates.

Coleman, R.G., and Kruckeberg, A.R., 1999, Geology and plant life of the Klamath-Siskiyou Mountain region: Natural Areas Journal, v.19, no. 4, p. 320-340.

Coleman, R.G., and Lanphere, M.A., 1971, Distribution and age of high grade blueschists, associated eclogites, and amphibolites from Oregon and California: Geological Society of America Bulletin , v. 82 , no. 9, p. 2397-2412.

Coleman, R.G., and Lanphere, M.A., 1991, The Briggs Creek amphibolite, Klamath Mountains, Oregon; its origin and dispersal: New Zealand Journal of Geology and Geophysics, v. 34, p. 271-284.

Coleman, R.G., Manning, C.E., Mortimer, N., Donato, M.M., and Hill, L.B., 1988, Tectonic and regional metamorphic framework of the Klamath Mountains and adjacent Coast Ranges, California and Oregon, in Ernst, W. G., ed., Metamorphism and crustal evolution of the western United States, Rubey Vol. 7: Prentice-Hall, Englewood Cliffs, New Jersey, p. 1061-1096.

Coleman, R.G., and Mayerle, R., 1984, Condrey Mountain Roadless Area, California, in Wilderness Mineral Potential, S. P. Marsh and others, eds.: U.S. Geological Survey Professional Paper 1300, v. 1, p. 208-210.

Coleman, R.G., Mortimer, N., Donato, M.M., Manning, C.E., and Hill, L.B., 1986, Metamorphic framework of the central Klamath Mtns. and adjacent Coast Ranges, Oregon and California: Geological Society of America, Abstracts with Programs, v. 18, no. 2, p. 96.

Coleman, R.G., and Peterman, Z.E., 1969, Colebrooke schist of southwestern Oregon: Geological Society of America, Cordilleran Section, 65th Annual Meeting, Program, Eugene, Oregon, pt. 3, p. 12-13.

Collins, T., and Hicks, B.G., 197l, Engineering Geology in a massively unstable region: Association of Engineering Geologists Annual Meeting, Program Abstract, no. 14, p. 22.

Condie, K.C., and Snansieng, S., 1971, Petrology and geochemistry of the Duzel (Orodovician) and Gazelle (Silurian) Formations, northern California: Journal of Sedimentary Petrology, v. 4l, no. 3, p. 741-751.

Condon, T., 1902, The two islands: Portland, Oregon, 211 p.

---1910, Oregon geology; a revision of "The two Islands": Edited by Ellen Condon McCornack: Portland, Oregon, $187 \mathrm{p}$.

Contor, R.J., 1963, The underworld of Oregon Caves National Monument: Crater Lake National Park, Oregon, Crater Lake Natural History Association, 37 p.

Coogan, A.H., 1957, Stratigraphy and correlation of the Permian Nosoni and Dekkas Formations, Shasta County, California: Geological Society of America Bulletin, v. 68, no. 12, pt. 2, p. 1821.

---1960, Stratigraphy and paleontology of the Permian Nosoni and Dekkas Formations (Bollibokka Group): Univ. Calif. Pubs. Geol. Sci., v. 36, p. 243-316.

Cornelius, R.R., 1984, Geology and tectonic setting of Rock Creek Butte, Klamath Mountains, California: Austin, University of Texas, M.A. thesis, 108 p., map scale 1:20,000.

---1986, Geology and structure of the Rock Creek Butte area, Del Norte County, Klamath Mountains, California: California Geology, v. 39, p. 195-201.

Cornell, J.H., III, 1971, Geology of the northwest quarter of the Canyonville quadrangle, Oregon: Eugene, University of Oregon, M. S. thesis, 64 p.

Cornwall, H.R., 1981, Chromite deposits in the Seiad Valley and Scott Bar quadrangles, Siskiyou County, California: U.S. Geological Survey Bulletin, 1382-D, 17 p.

Correa, A.C., 1974, A geological and statistical approach to the exploration for alpine-type chromite in California: Stanford University, Ph.D dissertation, $316 \mathrm{p}$.

Cotkin, M.L., and Cotkin, S.J., 1985, Structural style, metamorphism, and tectonic implications of early Paleozoic blueschist, eastern Klamath Mountains, California: Geological Society of America, Abstracts with Programs, v. 17, no. 6, p. 349.

Cotkin, S.J., 1986, Mineralogy and petrology of blueschist from the schist of Skookum gulch, eastern Klamath Mountains, California: Geological Society of America, Abstracts with Programs, v. 18, no. 2, p. 96.

---1987, Petrology and geochemistry of the Russian Peak pluton, Klamath Mountains, northern California: Madison, University of Wisconsin, Ph. D. dissertation, 306 p.

---1987, Conditions of metamorphism in an early Paleozoic blueschist, Skookum Gulch, northern California: Contributions to Mineralogy and Petrology, v. 96, p. 192-200.

---1989, The Callahan event: The expression of Ordovician-Silurian tectonism in northern California: Geological Society of America, Abstracts with Programs, v. 21, no. 5, p. 69. 
---1992, Ordovician-Silurian tectonism in northern California; the Callahan event: Geology, v. 20, no. 9, p. 821-824.

Cotkin, S.J., and Armstrong, R.L., 1987, Rb/Sr age, geochemistry, and tectonic significance of blueschist from Skookum Gulch, eastern Klamath Mountains, California: Introducing the Callahan event: Geological Society of America Abstracts with Programs, v. 19, no. 6, p. 367.

Cotkin, S.J., Cotkin, M.L., and Armstrong, R.L., 1992, Early Paleozoic blueschist from the schist of Skookum Gulch, eastern Klamath Mountains, northern California: Journal of Geology, v. 100, p. 323-338

Cotkin, S.J., and Grove, M., 1992, ${ }^{40} \mathrm{Ar} /{ }^{39} \mathrm{Ar}$ evidence of early Paleozoic subduction-zone metamorphism, schist of Skookum Gulch, eastern Klamath Mtns., northern California: Geological Society of America, Abstracts with Programs, v. 24, no. 5, p. 17.

Cotkin, S.J., and Medaris, L.G., 1991, Geologic evolution of a mid-Jurassic calcalkaline intrusive complex: The Russian Peak pluton, Klamath Mountains, California: Geological Society of America, Abstracts with Programs, v. 23, no. 5, p. 307.

---1993, Evaluation of the crystallization conditions for the calcalkaline Russian Peak intrusive complex, Klamath Mountains, northern California: Journal of Petrology, v. 34, no. 3, p. 543-571.

Cotkin, S.J., Medaris, L.G., and Arculus, R.J., 1987, Petrogenesis of the Russian Peak pluton, eastern Klamath Mountains, California: Geological Society of America Abstracts with Programs, v. 19, no. 6, p. 367.

Cotkin, S.J., Medaris, L.G., Jr., and Kistler, R.W., 1985, Rb-Sr systematics of the Russian Peak pluton, northern California: Eos (American Geophysical Union Trans.), v. 66, no. 46, p. 1118.

Cotkin, S.J., Medaris, L.G., and Valley, J.W., 1991, Physical and chemical effects of differing fluid contents in two units of the Russian Peak pluton, Klamath Mountains, California: Geological Society of America, Abstracts with Programs, v. 23, no. 2, p. 15.

Coulton, A.J., Harper, G.D., and O'Hanley, D.S., 1995, Oceanic versus emplacement age serpentinization in the Josephine ophiolite: Implications for the nature of the Moho at intermediate and slow spreading ridges: JGR, v. 100, n. B11, p. 22245-22260.

Cowan, D.S, 1980, Late Mesozoic tectonic events in the Pacific Northwest: Geological Society of America, Abstracts with Programs, v. 12, no. 3, p. 102.

---1993, Alternative models for Late Jurassic and Early Cretaceous paleogeography of the western Cordillera, California to SE Alaska: Geological Society of America Abstracts with Programs, v. 25, no. 5, p. 24.

Cowan, D.S., and Bruhn, R.L., 1992, Late Jurassic to early Late Cretaceous geology of the U.S. Cordillera, in Burchfiel, B.C., Lipman, P.W., and Zoback, M.L., eds., The Geology of North America Volume G-3, The Cordilleran Orogen: Conterminous U.S.: Geological Society of America, Boulder, Colorado, p. 169-203.

Cox, D.P., 1956, Geology of the Helena quadrangle, Trinity County, California: Stanford, California, Stanford University, Ph.D. dissertation, 123 p.

---1967, Reconnaissance geology of the Helena quadrangle, Trinity County California, in Short contributions to California geology: California Division of Mines and Geology Special Report 92, p. 43-55.

Cox, D.P., and Pratt, W.P., 1973, Submarine chert-argillite slide-breccia of Paleozoic age in the southern Klamath Mountains, California: Geological Society of America Bulletin, v. 84, no. 4, p. 1423-1438.

Cram-Barry, C.A., and Wallin, E.T., 1990, Stratigraphy and sedimentation of the Devonian Gazelle Formation, eastern Klamath Mountains, N. California: Geological Society of America, Abstracts with Programs, v. 22, no. 3, p. 15-16.

Cramer, R.S., 1982, Petrography, fluid inclusion, and light stable isotope study of the Gray Eagle $\mathrm{Cu}-\mathrm{Au}$ massive sulfide deposit, Siskiyou County California: Davis, University of California, M.S. thesis, $101 \mathrm{p}$.

Cramer, R.S., and Taylor, B.E., 1983, Oxygen, hydrogen and sulfur isotope geochemistry of the Gray Eagle $\mathrm{Cu}-\mathrm{Zn}$-Au deposit, Siskiyou County, California: location of the elusive vent area: Geological Society of America Bulletin, Abstracts with Programs, v. 15, no. 5, p. 297.

Crawford, J.J., 1894, Coal--Trinity County: California State Mining Bureau Report 12, p. 62-65.

---1896, Coal--Trinity County: California State Mining Bureau Report 13, p. 56.

Cridland, A.M., and Goles, G.G., 1996, The Geochemical features, origin and tectonic significance of some rodingites of the northern Klamath Mountains, Oregon: Geological Society of America, 
Abstracts with Programs, v. 28, no. 5, p. 58.

Cullers, R.L., Helmke, P., and Medaris, L.G., 1972, The rare-earth element distributions of some high temperature-pressure peridotites in southwestern Oregon: Geological Society of America, Abstracts with Programs, v. 4, no. 4, p. 277.

Cumberlidge, J.T., and Chace, F.M., 1968, Geology of the Nickel Mountain mine, Riddle, Oregon, in Ore deposits of the United States, 1933-1967 (Graton-Sales Volume), v. 2: New York, American Institute of Mining, Metallurgy and Petroleum Engineers, p. 1650-1672.

Cunningham, C.T., 1979, Geology and geochemistry of a massive sulfide deposit and associated volcanic rocks, Blue Creek district, southwestern Oregon: Corvallis, Oregon State University, M.S. thesis, $165 \mathrm{p}$.

Curtis, D.R., 1983, Stratigraphy and origin of the Pit Formation, northern California: Berkeley, University of California, M. S. thesis, $59 \mathrm{p}$.

Curtis, G.D., 1980, The stratigraphy and structure of portions of the Bonanza King and Schell Mountain quadrangles, Trinity County, California: San Jose, California State University, M.S. thesis, 132 p.

Curtis, G.H., Evernden, J.F., and Lipson, J.I., 1958, Age determination of some granitic rocks in California by the potassium-argon method: California Division of Mines Special Report 54, $16 \mathrm{p}$.

D'Allura, J.A., 1990, Geologic field guide along the Klamath River from Interstate 5 near Hornbrook to Seiad Valley, Siskiyou County, California: California Geology, v. 43, no. 3, p. 58-67.

D'Allura, J., Griffin, J.R., Lindsley-Griffin, N., and Moores, E.M., 1974, Cordilleran tectonic history--a view from northern California: Geological Society of America, 87th Annual Meeting, Program, Miami Beach, Florida, v. 6, no. 7, p. 704.

Dana, J.D., 1849, Notes on Upper California; From observations made during the cruise of the United States Exploring Expedition, under Capt. Charles Wilkes, U.S.N.: American Journal of Science, 2nd series, v. 7, p. 247-264.

---1849, Geological observations on Oregon and northern California, Chapter 17, in Geology: United States Exploring Expedition during the years 1838, 1839, 1840, 1841, 1842, under the command of Charlkes Wilkes, U.S.N.: New York, Geo. P. Putnam, 155 Broadway, p. 611-678.

Danielson, J.D., 1988, Lithology and geochemistry of the French Gulch inlier, Klamath Mountains, northern California: California State University, Chico, M.S. thesis, 230 p.

Danielson, J., and Bergk, K., 1993, From black smokers to acid mine drainage, in Field Guide and Abstracts: NAGT-FWS Fall 1993 Meeting, Bridge Bay Resort, CA, p. 20-31.

Danielson, J.D., and Silberman, M.L., 1987, Geologic setting of lode gold deposits in the Redding 1 X 2 degree quadrangle, Klamath Mountains, California: Geological Society of America Abstracts with Programs, v. 19, no. 6, p. 370.

Danielson, J.D., and Silberman, M.L., 1988, Geologic setting and characteristics of lode-gold deposits in the Redding 1 x 2degree quadrangle, Klamath Mountains, California, in Bicentennial Gold 88, Extended Abstracts Poster Programme, v. 1: Geological Society of Australia, Abstract Series no. 23, p. 311-315.

Danielson, J.D., Silberman, M.L., and Shafiqullah, M., 1990, Age of mineralization of gold-quartz veins at the Reid mine, eastern Klamath terrane, Shasta County, northern California: Geological Society of America, Abstracts with Programs, v. 22, no. 3, p. 17.

Davidson, E., 1922, History of discovery of the Marble Halls of Oregon: Oregon Hist. Quart., v. 23, p. 274-276.

Davidson, J.M., 1900, Register of mines and minerals, County of Siskiyou, California: California State Mining Bureau, $27 \mathrm{p}$.

Davis, G.A., 1961, Metamorphic and igneous geology of pre-Cretaceous rocks, Coffee Creek area, northeastern Trinity Alps, Klamath Mountains, California: Berkeley, California University, Ph.D. dissertation, 199 p.

---1962, "Stratigraphy" and structure of metamorphic rocks in the southwestern quarter of Coffee Creek quadrangle, Trinity Alps, Klamath Mountains, California: Geological Society of America Special Paper 68, p. 18-19.

---1962, Structure and mode of emplacement of a foliated, domical pluton, Klamath Mountains, California: Geological Society of America Special Paper 68, p. 159-160.

---1963, Structure and mode of emplacement of Caribou Mountain pluton, Klamath Mountains, California: Geological Society of America Bulletin, v. 74, no. 3, p. 331-348.

---1965, Correlation of Stuart Fork Formation with rocks of western Paleozoic and Triassic belt, Klamath Mountains, California: American Association of Petroleum Geologists Bulletin, v. 49, no. 
10, p. 1758-1759.

---1965, Regional Mesozoic thrusting in the south-central Klamath Mountains of California: Geological Society of America Special Paper 82, p. 248.

---1966, Age of thrusting and ultramafic intrusion in the south-central Klamath Mountains, California: Geological Society of America Special Paper 87, p. 42-43.

---1966, Metamorphic and granitic history of the Klamath Mountains, in Geology of northern California: California Division of Mines and Geology Bulletin 190, p. 39-50.

---1968, Tectonic correlations, Klamath Mountains and western Sierra Nevada, California: American Geophysical Union Transactions, v. 49, no. 4, p. 757.

---1968, Westward thrust faulting in the south-central Klamath Mountains, California: Geological Society of America Bulletin, v. 79, no. 7, p. 911-934.

---1969, Tectonic correlations, Klamath Mountains and western Sierra Nevada, California: Geological Society of America Bulletin, v. 80, no. 6, p. 1095-1108.

Davis, G.A., Ando, C.J., Cashman, P.H., and Goullaud, L., 1979, Cross section of the central Klamath Mountains, California: Geological Society of America, Map and Chart Series MC-28I, scale $1: 62,500$.

---1980, Geologic cross section of the central Klamath Mountains, California: Summary: Geological Society of America Bulletin, v. 91, no. 3, part 1, p. 139-142.

Davis, G.A., Holdaway, M.J., Lipman, P.W., and Romey, W.D., 1965, Structure, metamorphism, and plutonism in the south-central Klamath Mountains, California: Geological Society of America Bulletin, v. 76, no. 8, p. 933-966.

Davis, G.A., and Lipman, P.W., 1962, Revised structural sequence of pre-Cretaceous metamorphic rocks in the southern Klamath Mountains, California: Geological Society of America Bulletin, v. 73, no. 12, p. 1547-1552.

Davis, G.A., Monger, J.W.H., and Burchfiel, B.C., 1978, Mesozoic construction of the Cordilleran "collage," central British Columbia to central California, in Mesozoic paleogeography of the western United States, Howell, D.G., and McDougall, K.A., eds.: Society of Economic Paleontologists and Mineralogists, Pacific Section, Pacific Coast Paleogeography symposium 2, p. 1-32.

De La Fuente, J., Baldwin, K., Snavely, W., Koorda, S., Elder, D, Rose, E., and Haessig, P., 1997, Effects of storms ending January 1, 1977 on slope and channel processes: Central Klamath Mounains (Klamath National Forest): Geological Society of America, Abstracts with Programs, v. 29, no. 5, p. 10.

De La Fuente, J., Biery, E., Creasy, M., Elder, D., Haessig, P., Laurent, T., and Snavely, W., 1993, Geomorphic terranes of the central Klamath Mountains: Applications to ecosystem management: Geological Society of America, Abstracts with Programs, v. 25, no. 5, p. 29: Also in Field guide and abstracts: NAGT-FWS 1993 Meeting, Bridge Bay Resort, CA, p. A13.

De La Fuente, J., Elder, D., and Miller, A., 2002, Does deforestation influence the activity of deepseated landslides?: Observations from the flood of 1997 in the central Klamath Mountains, northern California: Geological Society of America, Abstracts with Programs, v. 34, no. 5, p. 88.

De La Fuente, J., and Haessig, P., 1992, Development of a sediment budget for the Salmon River basin, Klamath Mountains, northern California: Geological Society of America, Abstracts with Programs, v. 24, no. 5, p. 19.

Demirman, F., 1960, Sedimentation and diagenesis in the Permian McCloud Limestone, Shasta County, California: Stanford, Stanford University, M.S. thesis.

Demirman, F., and Harbaugh, J.W., 1965, Petrography and origin of Permian McCloud limestone of northern California: Journal of Sedimentary Petrology, v. 35, p. 136-154.

Derkey, R.E., 1980, The Silver Peak volcanogenic massive sulfide, northern Klamath Mountains, Oregon: Geological Society of America, Abstracts with Programs, v. 12, no. 3., p. 104.

---1981, The Silver Peak volcanogenic massive sulfide, northern Klamath Mountains, Oregon: U.S. Geological Survey Open-File Report 81-355.

---1982, Geology of the Silver Peak mine, Douglas County, Oregon: University of Idaho, Ph.D. dissertation, $188 \mathrm{p}$.

Dick, H.J.B., 1973, K-Ar dating of intrusive rocks in the Josephine peridotite and Rouge Formation west of Cave Junction, southwestern Oregon: Geological Society of America, Abstracts with Programs, v. 5, no. 1, p. 33.

---1974, Terrestrial nickel-iron from the Josephine Peridotite, its geologic occurrence, associations, and 
origin: Earth and Planetary Science Letters, v. 24, no. 2, p. 291-298.

---1975, Partial melting in the Josephine peridotite and its consequence for pyroxene geobarometry and thermometry, in Boettcher, A. L., ed., International conference on geothermometry and geobarometry: Pennsylvania State University, p. 4.

---1975, The Josephine peridotite, a refractory residue of the generation of andesite: Eos, (American Geophysical Union Trans.), v. 56, no. 6, p. 464.

---1976, The origin and emplacement of the Josephine Peridotite of southwestern Oregon: New Haven, Connecticut, Yale University, Ph.D. dissertation, 409 p.

---1977, Evidence of partial melting in the Josephine peridotite, in Magma genesis 1977;proceedings of the American Geophysical Union Chapman conference on partial melting in the Earth's upper mantle, Dick, H. J. B., ed.: Oregon Department of Geology and Minerals Industries Bulletin, v. 96, p. 59-62.

---1977, Partial melting in the Josephine Peridotite; The effect on mineral composition and its consequence for geobarometry and geothermometry: American Journal of Science, v. 277, no. 7, p. 801-832.

Dick, H.J.B., and Gillete, H., 1976, Josephinite-specimens from the core?: a discussion: Earth and Planetary Scienc Letters, v. 31, p. 308-311.

Dick, H.J.B., and Sinton, J.M., 1979, Compositional layering in alpine peridotites; evidence for pressure solution creep in the mantle: Journal of Geology, v. 87, no. 4, p. 403-416.

Dicken, S.N., 1952, The Rogue River Country of Oregon--a study in regional geography: Association of Pacific Coast Geographers Yearbook, v. 14, p. 3-18.

Dickinson, W.R., Ingersoll, R.V., and Graham, S.A., 1979, Paleogene sediment dispersal and paleotectonics in northern California: Geological Society of America Bulletin, v. 90, no. 10, p. 897898 and 1458-1528.

Diggles, M.F., and Kennedy, G.L., 1986, Geologic and geochemical-anomaly map of the Tunnel Ridge Wilderness Study Area, Klamath Mountains, California: U.S. Geological Survey, Miscellaneous Field Studies Map MF-1810-B, scale 1:24,000.

Diggles, M.F., Kennedy, G.L., Detra, D.E., and Sharkey, J.D., 1984, Geochemical data for samples of rock, stream sediment, and nonmagnetic heavy-mineral concentrate from the Tunnel Ridge Wilderness Study Area, Klamath Mountains, California: U.S. Geological Survey, Open-File Report 84-0887, $79 \mathrm{p}$.

Diller, J.S., 1884, Geologic work in northern California and in Oregon: Science, no. 3, p. 366.

---1885, Coal in the Chico group of California: Science, no. 5, p. 43.

---1886, Notes on the geology of northern California: U.S. Geological Survey, Bulletin 33, 23 p.

---1891, Report of Mr. Diller, Cascade Division, in Administrative reports by Heads of Divisions: U.S. Geological Survey, 11th Annual Report, Part 1, p. 90-94.

---1893, Cretaceous and early Tertiary of northern California and Oregon: Geological Society of America Bulletin, no. 4, p. 205-224.

---1894, Revolution in the topography of the Pacific Coast since the auriferous gravel period: Journal of Geology, v. 2, p. 32-54.

---1894, Tertiary revolution in the topography of the Pacific Coast: U.S. Geological Survey Annual Report, no. 14, pt. 2, p. 397-434.

---1896, The Klamath Mountains, Oregon: Mazama 1, p. 104-108.

---1898, Description of the Roseburg quadrangle (Oregon): U.S. Geological Survey Geological Atlas, Folio 49, 4 p.

---1900, The Bohemia mining region of western Oregon: U.S. Geological Survey, Annual Report 20, pt. 3, p. 1-36.

---1902, Copper in northern California: Mining and Science Press, no. 85, p. 62, 72.

---1902, Topographic development of the Klamath Mountains: U.S. Geological Survey, Bulletin 196, 69 p.

---1903, Copper deposits of the Redding region, California: U.S. Geological Survey, Bulletin 213, p. 123-132.

---1903, Description of the Port Orford quadrangle (Oregon): U.S. Geological Survey, Geologic Atlas Port Orford folio, no. 89, 6 p.

---1903, Iron ores of the Redding quadrangle, California: U.S. Geological Survey, Bulletin 213, p. 219-220.

---1903, Klamath Mountain section, California: American Journal of Science, 4th series, v. 15, p. 
342-362.

---1903, Limestone of the Redding district, California: U.S. Geological Survey, Bulletin 213, p. 365.

---1904, Mining and mineral resources in the Redding quadrangle, California in 1903: U.S. Geological Survey, Bulletin 225, p. 169-179.

---1904, The composition and structure of the Klamath Mountains: Science, no. 19, p. 794.

---1905, Mineral resources of the Indian Valley region, California: U.S. Geological Survey, D260, p. 45-49.

---1905, The Bragdon formation: American Journal of Science, v. 4, no. 19, p. 379-387.

---1906, Description of the Redding quadrangle [California]: U.S. Geological Survey, Geologic Atlas Redding folio, no. 138, 14 p.

---1907, Age of the pre-volcanic auriferous gravels in California: Washington Academy of Sciences Proceedings 8, p. 405-406.

---1907, The Mesozoic sediments of southwestern Oregon: American Journal of Science, ser. 4, v. 23, p. 401-421.

---1908, Placer mines of the Riddles quadrangle, Oregon: U.S. Geological Survey, Bulletin 340, p. 147-151.

---1908, Strata containing the Jurassic flora of Oregon: Geological Society of America, Bulletin 19, p. 367-402.

---1911, The auriferous gravels of the Trinity River basin, California: U.S. Geological Survey, Bulletin 470, p. 11-29.

---1912, Mines and prospects of southwestern Oregon: Washington Academy of Sciences, Journal of 2, p. 110.

---1914, Auriferous gravels in the Weaverville, quadrangle, California: U.S. Geological Survey, Bulletin 540, p. 11-21.

---1914, Mineral resources of southwestern Oregon: U.S. Geological Survey, Bulletin 546, 147 p.

---1921, Chromite in the Klamath Mountains, California and Oregon: U.S. Geological Survey Bulletin 725-A, p. 1-35.

Diller, J.S., and Kay, G.F., 1909, Mineral resources of the Grants Pass quadrangle and bordering districts, Oregon: U.S. Geological Survey Bulletin 380, p. 48-79.

---1924, Description of the Riddle quadrangle (Oregon): U.S. Geological Survey Geological Atlas, Folio $218,8 \mathrm{p}$.

Diller, J.S., and others, 1915, Guidebook of the western United States; Part D, The Shasta route and coast line: U.S. Geological Survey, Bulletin 614, $142 \mathrm{p}$.

Diller, J.S., and Schuchert, C., 1894, Discovery of Devonian rocks in California: American Journal of Science, 3d series, v. 47, p. 416-422.

Diller, J. S., and Stanton, T. W., 1894, The Shasta-Chico series, Geological Society of America, Bulletin 5, p. 435-464.

Dittmar, M.E., 1899, Northern California's resources, in California mines and minerals: California Miner's Association, Souvenir edition, Louis Roesch Company, San Francisco, California, p. 370-379.

---1902, Register of mines and minerals, Shasta County, California: California State Mining Bureau, 15 p.

Doe, B.R., Delevaux, M.H., and Albers, J.P., 1985, The plumbotectonics of the West Shasta mining district, eastern Klamath Mountains, California: Economic Geology, v. 80, no. 8, p. 2136-2148.

Dole, H.M., and Baldwin, E.M., 1947, A reconnaissance between the Almeda and Silver Peak mines of southwestern Oregon: Ore Bin, v. 9, no. 12, p. 95-100.

Dole, H., Libbey, F.W., and Mason, R.S., 1948, Nickel-bearing laterite areas of southwestern Oregon: The Ore.-Bin, v. 10, no. 5, p. 33-38.

Doolittle, J.E., 1908, Gold dredging in California: California State Mining Bureau Bulletin 36, 119 p. [Shasta Co., p. 98-101; Trinity Co., p. 102-104; Siskiyou Co., p. 105-108].

Dollinger, G., 1969, A petrofabric study of olivine from the Seiad ultra-mafic complex, Seiad Valley, California: Madison, Wisconsin University, M.S. thesis, 71 p.

Donato, M.M., 1975, The geology and petrology of a portion of the Ashland pluton, Jackson County, Oregon: Eugene, Oregon University, M.S. thesis, 89 p.

---1982, Geologic map of the Marble Mountain Wilderness area, Klamath Mountains, California:

Geological Society of America, Abstracts with Programs, v. 14, no. 4, p. 161.

---1984, Metamorphic and structural evolution of a tectonic melange, Klamath Mountains, northern 
California: Geological Society of America, Abstracts with Programs, v. 16, no. 6, p. 492.

---1985, Metamorphic and structural evolution of an ophiolitic tectonic melange, Marble Mountains, northern California: Stanford, Stanford University, Ph. D. dissertation, 258 p.

---1986, Tectonic implications of polyphase metamorphic history of the Marble Mountain terrane, northern California Klamath Mountains: Geological Society of America, Abstracts with Programs, v. 18, no. 2, p. 102.

---1987, The May Creek Schist, southwestern Oregon: Remnant of an incipient back arc basin?: Geological Society of America Abstracts with Programs, v. 19, no. 6, p. 373.

---1987, Evolution of an ophiolitic tectonic melange, Marble Mountains, northern California Klamath Mountains: Geological Society of America Bulletin, v. 98, p. 448-464.

---1989, Metamorphism of an ophiolitic tectonic melange, northern California, Klamath Mountains, U.S.A.: Journal of Metamorphic Geology, v. 7, p. 515-528.

---1990, A newly-recognized ductile shear zone in the northeastern Klamath Mountains: Geological Society of America, Abstracts with Programs, v. 22, no. 3, p. 19.

---1991, Geologic map showing part of the May Creek Schist and related rocks, Jackson County, Oregon: U.S. Geological Survey Miscellaneous Field Studies Map MF-2171, scale 62,500.

---1991, Geochemical recognition of a captured back-arc basin metabasaltic complex, southwestern Oregon: Journal of Geology, v. 99, no. 5, p. 711-728.

---1992, A newly recognized ductile shear zone in the northern Klamath Mountains, Oregon: Implications for Nevadan accretion: U. S. Geological Survey Bulletin 2028, 10 p.

---1992, Geologic guide for the northern Klamath Mountains: Part 2, Red Mountain to Bald Mountain (May Creek Schist and related rocks): Oregon Geology, v. 54, no. 2, p. 34-39.

---1992, Preliminary geologic map of the Carberry Creek quadrangle, Oregon and California: U. S. Geological Survey, Open-File Report 92-695, scale 1:24,000.

---1993, Preliminary geologic map of the Squaw Lakes quadrangle, Oregon and California: U. S. Geological Survey Open-File Report 93-703, scale 1:24,000.

Donato, M.M., Barnes, C.G., Coleman, R.G., Ernst, W.G., and Kays, M.A., 1982, Geologic map of the Marble Mountain Wilderness, Siskiyou County, California: U.S. Geological Survey, Miscellaneous Field Studies Map MF-1452-A, scale 1:48,000.

Donato, M.M., Barnes, C.G., and Gray, G.G., 1983, Geologic map of the Orleans Mountain Roadless area, Humboldt and Siskiyou Counties, California: U.S. Geological Survey, Miscellaneous Field Studies Map MF-1526-A, scale 1:48,000.

Donato, M.M., Barnes, C.G., and Irwin, W.P., 1981, Northward continuation of the Hayfork Terrane, north-central Klamath Mountains, California: Geological Society of America, Abstracts with Programs, v. 13, no. 2, p. 52.

Donato, M.M., Barnes, C.G., and Tomlinson, S.L., 1996, The enigmatic Applegate Group of southwestern Oregon: Age, correlation, and tectonic affinity: Oregon Geology, v. 58, p. 79-91.

Donato, M.M., and Coleman, R.G., 1979, Deformation and metamorphism of the schist of Condrey Mountain, Klamath Mountains, California and Oregon: Geological Society of America, Abstracts with Programs, v. 11, no. 3, p. 75.

Donato, M.M., Coleman, R.G., and Kays, M.A., 1980, Geology of the Condrey Mountain Schist, northern Klamath Mountains, California and Oregon: Oregon Geology v. 42, no. 7, p. 125-129.

Donato, M.M., and Hale, W.N., 1984, Marble Mountain Wilderness, California, in S. P. Marsh and others, eds., Wilderness Mineral Potential: U.S. Geological Survey Professional Paper 1300, v. 1, p. 286-288.

Donato, M.M., Jachens, R.C., Smith, D.B., and Hale, W.N., 1983, Mineral resource potential map of the Marble Mountain Wilderness, Siskiyou County, California: U. S. Geological Survey, Miscellaneous Field Studies Map MF-1452-B, scale 1:48,000, with text, 11 p.

Donato, M.M., and Lanphere, M.A., 1992, Geochronologic studies of selected amphibolites in the northern Klamath Mountains: Geological Society of America, Abstracts with Programs, v. 24, no. 5, p. 20.

Donato, M.M., and Linne, J.M., 1984, Orleans Mountain Roadless Area (B5079), California, in S. P. Marsh and others, eds., Wilderness Mineral Potential: U.S. Geological Survey Professional Paper 1300, v. 1, p. 319-322.

Donato, M.M., Linne, J.M., Jachens, R.C., and Smith, D.B., 1983, Mineral resource potential of the Orleans Mountain Roadless Area, Humboldt and Siskiyou Counties, California: U.S. Geological Survey, Miscellaneous Field Investigations Map MF-1526-B, scale 1:48,000, with 11 page text. 
Donato, M.M., Weston, P.E., and Barnes, C.G., 1994, Detrital clinopyroxene chemistry as a key to Middle Jurassic volcanism in the north-central Klamath Mountains: Geological Society of America, Abstracts with Programs, v. 26, no. 7, p. 193-194.

Dong, A.E., Beatty, K.W., and Averett, R.C., 1974, Limmological study of Lake Shastina, Siskiyou County, California: U.S. Geological Survey, Water Resources Investigations, no. 11-74, 52 p.

Doolittle, J.E., 1908, Gold dredging in California: California State Mining Bureau Bulletin 36, 119 p.

Dorais, M.J., 1983, The geology and petrology of the Shelly Lake pluton, central Klamath Mountains, California: Eugene, Oregon University, M. Sc. thesis

Dott, R.H., Jr., 1963, Classic Nevadan orogenesis in southwestern Oregon: Geological Society of America, Program, Annual Meeting, Berkeley, California, p. 29-30: also 1964, Geological Society of America Special Paper 76, p. 197-198.

---1965, Mesozoic-Cenozoic tectonic history of the southwestern coast in relation to Cordilleran orogenesis: Journal of Geophysical Research, v. 70, no. 18, p. 4687-4707.

---1966, Cordilleran and Cascadan orogenies in western North America: Geological Society of America Special Paper 87, p. 47-48.

---1966, Late Jurassic unconformity exposed in southwestern Oregon: Ore Bin, v. 28, no. 5, p. 85-97.

---1971, Geology of the southwestern Oregon coast west of the 124th meridian: Oregon Department of Geology and Mineral Industries Bulletin 69, 63 p.

Dott, R.H., Jr., and Bourgeois, J., 1980, Late Mesozoic tectonics and sedimentation along the southwestern Oregon coast: Geological Society of America, Abstracts with Programs, v. 12, no. 3, p. 104.

Douglass, R.C., 1966, Permian Tethyan fusulinids from California: Geological Society of America, Program, Annual Meeting, San Francisco, California, p. 57-58.

$\mathrm{Du}$, Yue, 1994, Application of modern island biogeography theory to two Late Triassic oceanic islands, Wallowa terrane and Eastern Klamath terrane: Geological Society of America, Abstracts with Programs, v. 26, no. 7, p. 57.

Du, Yue, Stanley, G.D., Jr., and McCormick, M., 1992, Reinterpretation of the Hosselkus Limestone of Eastern Klamath terrane: Late Triassic olistostromes in a volcanic arc basin: Geological Society of America, Abstracts with Programs, v. 24, no. 5, p. 21.

Dunn, R.L., 1892, Siskiyou County: California State Mining Bureau, 11th Report State Mineralogist, p. $420-452$.

---1892, Trinity County: California State Mining Bureau, 11th Report State Mineralogist, p. 480-484.

---1894, Auriferous conglomerate in California: California State Mining Bureau, 12th Report State Mineralogist, p. 459-471.

Dunn, S.R., Aalto, K.R., Abitz, R.J., and Gilliam, C.E., 1993, Tectonic blocks at Horse Mountain N. California; a unique occurrence of mafic blueschists in serpentinite along the South Fork Fault adjacent to the Klamath Mountains: Geological Society of America Abstracts with Programs, v. 25 , no. 5 , p. 33.

Dunning, G.E., and Cooper, J.F., Jr., 1987, Inesite from the Hale Creek mine, Trinity County, California: The Mineralogical Record, v. 18, no. 5, p. 341-347.

---1995, Troilite from the Low Divide district, Del Norte County, California: California Geology, September/October, p. 119-128.

Durst, T.L., 1976, The mineralogical and chemical development of the Nickel Mountain (Oregon) nickel laterite deposit: Cleveland, Case Western Reserve University, Ph. D. dissertation, 266 p.

Dutro, J.T., 1955, Occurrence of the brachiopod Isogramma in the Baird Formation of California: Journal of Paleontology, v. 29, no. 5, p. 920-922.

Dutton, C.E., 1891, The crystalline rocks of northern California and southern Oregon: International Geological Congress, IV, London 1888, CR, p. 176-179.

Eakle, A.S., 1922, Massive Troilite from Del Norte County, California: American Mineralogist, v. 7, no. 5, p.77-80.

Eastoe, C.J., 1992, Zoned depletion of base metals in basalt and andesite beneath volcanogenic massive sulfide deposits, East Shasta District, California: Geological Society of America, Abstracts with Programs, v. 24, no. 7, A318.

Eastoe, C.J., and Gustin, M.M., 1986, The Pit Formation, Shasta Lake, California: debris flow sedimentation and exhalite formation: Geological Society of America, Abstracts with Programs, v. 18, no. 2, p. 103.

Eastoe, C.J., Gustin, M.M., and Nelson, S.E., 1987, Problems of recognition of olistostromes: An example 
from the lower Pit Formation, Eastern Klamath Mountains, California: Geology, v. 15, no. 6, p. 541-544.

Eastoe, C.J., and Nelson, S.E., 1988, A Permian Kuroko-type hydrothermal system, Afterthought-Ingot area, Shasta County, California: Lateral and vertical sections, and geochemical evolution: Economic Geology, v. 83, p. 588-605.

Elder, D.R., 1991, Tectonic control of lode gold deposits, Quartz Hill, Klamath Mountains, California: Arcata, California, Humboldt State University, M.Sc. thesis, 106 p.

Elder, D.R, and Cashman, S.M., 1990, Redefinition of early Mesozoic terranes, central Klamath Mountains, California: Geological Society of America, Abstracts with Programs, v. 22, no. 3, p. 21.

---1991, Tectonic control of lode gold deposits, Quartz Hill, Klamath Mountains, California: Geological Society of America, Abstracts with Programs, v. 23, no. 2, p. 21.

---1992, Tectonic control and fluid evolution in the Quartz Hill, California, lode gold deposits: Economic Geology, v. 87, p. 1795-1812.

---1993, Tectonic control and fluid evolution in the Quartz Hill, California, lode gold deposits, in Field guide and abstracts: NAGT-FWS Fall 1993 Meeting, Bridge Bay Resort, CA, p. A15.

Eisbacher, G.H., 1983, Devonian-Mississippian sinistral transcurrent faulting along the cratonic margin of western North America: A hypothesis: Geology, v. 11, p. 7-10.

Elias, R.J., and Potter, A.W., 1984, Late Ordovician solitary rugose corals of the eastern Klamath Mountains, northern California: Journal of Paleontology, v. 58, no. 5, p. 1203-1214.

---1984, Biostratigraphic, biogeographic, and paleoecologic significance of Late Ordovician solitary rugose corals from the eastern Klamath Mountains, northern California: Geological Association of Canada, Program with Abstracts, v. 9, p. 59.

Elliott, M.A., 1971, Stratigraphy and petrology of the Late Cretaceous rocks near Hilt and Hornbrook, Siskiyou County, California, and Jackson County, Oregon: Corvallis, Oregon State University, Ph.D. dissertation, $171 \mathrm{p}$.

---1974, Late Cretaceous sublittoral and fluvial sedimentation, Klamath Mountains, Oregon: Geological Society of America, Abstracts with Programs, v. 6, no. 3, p. 172-173.

---1984, Geologic and geographic setting of the Hornbrook Formation, Oregon and California, in Nilsen, T.H., ed., Geology of the Upper Cretaceous Hornbrook Formation, Oregon and California: Society of Economic Paleontologists and Mineralogists, Pacific Section Publication No. 42, p. 43-50.

Elliott, M.A., and Bostwick, D.A., 1973, Occurrence of Yabeina in the Klamath Mountains, Siskiyou County, California: Geological Society of America, Abstracts with Programs, v. 5, no. 1, p. 38.

Ellis, R.K., 1977, Podiform chromite occurrences in the Josephine Peridotite, Klamath Mountains, northwestern California: Santa Barbara, University of California, M.S. thesis.

Elphic, L., 1969, The geology of the southern one-third of the Glide quadrangle, Oregon: Eugene, University of Oregon, M. S. thesis, 78 p.

Emerson, D.O., 1969, Albitization of the Pit River stock, Shasta County, California: Geological Society of America Special Paper 121, p. 89.

Engelhardt, C.L., 1966, The Paleozoic-Triassic contact in the Klamath Mountains, Jackson County, southwestern Oregon: Eugene, Oregon University, M.S. thesis, 98 p.

Erftenbeck, C.F., 1948, Northern California: National Speleological Society Bulletin, no. 10, p. 129130.

Eric, J.H., 1948, Tabulation of copper deposits of California, in Copper in California: California Division of Mines Bulletin 144, p. 199-357.

Ernst, W.G., ed., 1981, The geotectonic development of California: Englewood Cliffs, New Jersey, Prentice Hall, 706 p.

Ernst, W.G., 1983, Phanerozoic continental accretion and the metamorphic evolution of northern and central California-- The terrane concept revisited, in Howell, D.G., Jones, D. L., Cox, A., and Nur, A. , eds., Proceedings of the circum- Pacific terrane conference: Stanford, California, Stanford University:, p. 86-88.

---1987, Mafic meta-igneous arc rock of apparent komatiitic affinities, Sawyers Bar area, central Klamath Mountains, northern California, in B. O. Mysen, ed., Magmatic processes: Geophysical principles: The Geochemical Society, Special Publication No. 1, p. 191-208.

---1990, Accretionary terrane in the Sawyers Bar area of the Western Triassic and Paleozoic belt, central Klamath Mountains, northern California, in Harwood, D.S., and Miller, M.M., eds., Paleozoic and early Mesozoic paleogeographic relations; Sierra Nevada, Klamath Mountains, 
and related terranes; Geological Society of America Special Paper 255, p. 297-306.

---1991, Petrological setting and inferred plate tectonic history of the Sawyers Bar terrane, central Klamath Mountains, northern California: Canadian Mineralogist, v. 29, p. 1051-1068.

---1992, Metamorphism of the western Cordillera and its relationship to tectonics, in Burchfiel, B.C., Lipman, P.W., and Zoback, M.L., eds., The Geology of North America Volume G-3, The Cordilleran Orogen: Conterminous U.S.: Geological Society of America, Boulder, Colorado, p. 515538.

---1997, Geologic map of the Sawyers Bar area_Evolution of an oceanic island arc, central Klamath Mountains, California: Geological Society of America, Abstracts with Programs, v. 29, no. 5, p. 12.

---1998, Geologic map of the Sawyers Bar area: Geochemical/petrotectonic evolution of an oceanic island arc, central Klamath Mountains, California: California Division of Mines and Geology, Map Sheet 47, scale 1:48,000, with text 59 p.

---1999, Mesozoic petrotectonic development of the Sawyers Bar suprasubduction-zone arc, central Klamath Mountains, northern California: Geological Society of America Bull., 111, n. 8, 1217-1232.

Ernst, W.G., Hacker, B.R., Barton, M.D., and Sen, G., 1990, Petrochemistry and occurrence of early Mesozoic magnesian metavolcanic rocks, Western Triassic and Paleozoic belt, central Klamath Mountains, California: Geological Society of America, Abstracts with Programs, v. 22, no. 3, p. 21.

---1991, Occurrence, geochemistry and igneous petrogenesis of magnesian metavolcanic rocks from the central Klamath Mountains, northern California: Geological Society of America Bulletin, v. 103, no. 1 , p. 56-72.

---1993, Chemically distinct mafic dike/ sill sequences of contrasting age ranges, Sawyers Bar area, central Klamath Mountains, northern California: Journal of Petrology, v. 34, pt. 1, p. 63-75.

Ernst, W.G., and Kolodny, Y., 1997, Submarine and superimposed contact metamorphic oxygen isotopic exchange in an oceanic arc, Sawyers Bar area, central Klamath Mountains, Califonia: Geochem. Cosmochim. Acta, v. 61, p. 821-834.

Erskine, M.C., Wolleben, J.A., and Lawler, D.L., 1984, A potenital-field interpretation of the structural edge of the Cretaceous Hornbrook basin in northern California, in Nilsen, T.H., ed., Geology of the Upper Cretaceous Hornbrook Formation, Oregon and California: Society of Economic Paleontologists and Mineralogists, Pacific Section Publication No. 42, p. 211-219.

Eschelbacher, J.W., and Wallin, E.T., 1998, Assembly of a subduction complex during Early to Middle Devonian, Yreka subterrane, California: Geological Society of America, Abstracts with Programs, v. 30, no. 5, p. 13.

Evans, J.G., 1980, Structure of the Josephine Peridotite, California and Oregon: Geological Society of America, Abstracts with Programs, v. 12, no. 3, p. 105.

---1984, Structure of part of the Josephine Peridotite, northwestern California and southwestern Oregon: U. S. Geological Survey Bulletin 1546-A, p. 6-37.

---1987, Deformation of the Josephine Peridotite, California and Oregon: U.S. Geological Survey Prof. Paper 1378, 45 p.

Evans, J.R., 1966, Geology and petrology of the McCloud Limestone in the South Gray Rocks area, Shasta County, California: Geological Society of America Special Paper 87, p. 202-203.

---1969, Geology of the McCloud Limestone in the South Gray Rocks area, Shasta County, California--with a section on the operation of the Gray Rocks cement plant, in Geologic guide to the Lassen Peak, Burney Falls, and Lake Shasta area, California: Geological Society of Sacramento, Annual field Trip Guidebook, p. 79-92.

---1977, Economic geology of McCloud Limestone, South Gray Rocks area, Shasta County, California: California Geological Society, v. 30, no. 6, p. 123-132.

Evernden, J.F., and Kistler, R.W., 1970, Chronology of emplacement of Mesozoic batholithic complexes in California and western Nevada: U.S. Geological Survey Professional Paoper 623, 42 p.

Evoy, B.L., 1982, Complex mass movements of eastern Little Rattlesnake Mountain, Six Rivers National Forest, Del Norte County, California: Santa Cruz, California University, M. Sc. thesis.

Fagin, S.W., 1983, Paleogeography and tectonics of the Redding section, eastern Klamath belt, northern California: Austin, University of Texas, Ph.D. dissertation, 224 p.

---1980, Structural and depositional patterns in the Redding section of the eastern Klamath Mountains, northern California: Geological Society of America, Abstracts with Programs, v. 12, no. 3, p. 105.

Fagin, S.W., and Gose, W.A., 1983, Paleomagnetic data from the Redding section of the eastern Klamath belt, northern California: Geology, v. 11, no. 9, p. 505-508.

Fahan, M.R., 1982, Geology and geochronology of a part of the Hayfork terrane, Klamath Mountains, 
northern California: Berkeley, California University, M.S. thesis, 127 p.

Fahan, M.R., and Smith, B.K., 1986, Microstructural analysis of deformed metamorphic minerals from Pigeon Point, western Hayfork terrane, Klamath Mountains, California: Geological Society of America, Abstracts with Programs, v. 18, no. 2, p. 105.

Fahan, M.R., and Wright, J.E., 1983, Plutonism, volcanism, folding, regional metamorphism and thrust faulting: contemporaneous aspects of a major Middle Jurassic orogenic event within the Klamath Mountains, northern California: Geological Society of America, Abstracts with Programs, v. 15, no. 5 , p. 272.

---1984, The Eastern Hayfork terrane: a Permo-Triassic subduction complex, southwestern Klamath Mountains, California: Geological Society of America, Abstracts with Programs, v. 16, no. 6, p. 505.

Fairbanks, H.W., 1893, Geology and mineralogy of Shasta County, in 11th Report of the State Mineralogist: California State Mining Bureau, p. 24-53.

---1894, Localities of Mesozoic and Paleozoic in Shasta County, California: American Geologist, v. 14, p. 25-31.

---1895, Auriferous conglomerate in California: Engineering and Mining Journal, series 59, p. 389-390.

Farquhar, F.P., 1974, Up and down California in 1860-1864; Journal of William H. Brewer, Professor of Agriculture in the Sheffield Scientific School from 1864 to 1903: University of California Press, Berkeley, California Library Reprint Series Edition, 583 p.

Fiebelkorn, R.B., Walker, G.W., MacLeod, N.S., McKee, E.H., and Smith, J.G., 1983, Index to K-Ar determinations for the state of Oregon: Isochron/West, no. 37, $60 \mathrm{p}$.

Ferguson, H.G., 1914, Gold lodes of the Weaverville quadrangle, California: U.S. Geological Survey Bulletin 540, p. 22-79.

---1915, Pocket deposits of the Klamath Mountains, California: Economic Geology, v. 10, p. 241-261.

Ferns, M.L., 1979, The petrology and petrography of the Wrangle Gap-Red Mountain ultramafic body, Klamath Mountains, Oregon: Eugene, University of Oregon, M.S. thesis, 125 p.

Ferns, M.L., and Kays, M.A., 1978, Contrasting metamorphic terranes of Siskiyou Mountains, Oregon-California, in Van Atta, R. O., and others, eds., Proceedings of the thirty-sixth annual meeting of the Oregon Academy of Science: Oregon Academy of Science, Proceedings, v. 14, p. $148-149$.

Ferrero, T., 1990, The Liberty gold mining district, Siskiyou County, California: California Geology, v. 43 , no. 6, p. $123-133$.

Ferrero, T., Jones, R.C., Sonnevil, R., and Purdom, W.B., 1992, Slope stability mapping in the Klamath Mountains and Coast Ranges geologic provinces of western Oregon: Geological Society of America, Abstracts with Programs, v. 24, no. 5, p. 23.

---1992, High angle, Tertiary faulting and large scale landslides in the Siskiyou Mountains, Curry Country, Oregon: Geological Society of America, Abstracts with Programs, v. 24, no. 5, p. 24.

Fidler, W.W., 1922, An account of the first attempt at exploration of the Oregon Caves: Oregon Hist. Quart., v. 23, p. 270-273.

Fifarek, R.H., 1992, Metamorphic, tectonic, and hydrothermal modification of the Banfield and Rowley Besshi-type volcanogenic massive sulfide systems, SW Oregon: Geological Society of America Abstracts with Programs: v. 24, no. 7, p. 234.

Flory, R.A., and Watkins, R., 1983, Biostratigraphic relations of lower Paleozoic tabulate corals from northern California: Geological Society of America Bulletin, Abstracts with Programs, v. 15, no. 5, p. 409.

Foose, M.P., 1986, Setting of a magmatic sulfide occurrence in a dismembered ophiolite, southwestern Oregon: U. S. Geological Survey Bulletin 1626-A, 23 p.

---1992, Nickel; mineralogy and chemical composition of some nickel-bearing laterites in southern Oregon and northern California, in DeYoung, J.H., Jr., and Hammarstrom, J. M., eds., Contributions to commodity geologic research: U.S. Geological Survey Bulletin 1877, p. E1-E24.

Forstner, W., 1903, Quicksilver resources of California: California State Mining Bureau Bulletin 27, 273 p. [Trinity County, p. 190-195].

---1907, Copper in Shasta County, California: Mining and Science Press, v. 94, p. 625-626.

---1908, The genesis of the copper ores in Shasta County, west of the Sacramento River: Mining and Science Press, v. 97, p. 261-262.

Foster, F.G., 1980, The Iron Mountain Mine, West Shasta copper-zinc district, Shasta County, California, in Loyd, R. C., and others, eds., Mineral resource potential of California: Society of 
Mining Engineering, Transactions, Sierra Nevada Section, Sacramento, California, p. 72-78.

Fraticelli, L.A., 1984, Geology of portions of the Project City and Bella Vista quadrangles, Shasta County, California: San Jose, California State University, M.S. thesis, 110 p.

Fraticelli, L.A., Albers, J.P., and Zartman, R.E., 1985, The Permian Pit River stock of the McCloud plutonic belt, Eastern Klamath terrane, northern California: Isocron/West, no. 44, p. 6-8.

Fraticelli, L.A., Albers, J. P., Irwin, W. P., and Blake, M. C., Jr., 1987, Geologic map of the Redding 1 X 2 degree quadrangle, Shasta, Tehama, Humboldt, and Trinity Counties, California: U. S. Geological Survey Open-File Report 87-257, map scale 1:250,000, with 15 p. text.

Fredericks, P.E., Jr., 1980, Volcanic lithofacies and massive sulfide mineralization, East Shasta District, California: Austin, University of Texas, M.S. thesis, 111 p.

Friedrich, G.H., and Hawkes, H.E., 1967, Mercury dispersion haloes as prospecting indicators at the base-metal deposits, West Shasta district, California, in Symposium on geochemical prospecting, Ottawa, 1966, Proceedings: Canada Geological Survey Paper 66-54, p. 270.

Frishman, D., 1980, High- and low-temperature mineral assemblages in the Josephine Peridotite, Del Norte County, California; implications for geothermometers and geobarometers applied to alpine-type harzburgites: Los Angeles, University of California, Ph.D. dissertation, 356 p.

Frost, C.D., Barnes, C.G., Snoke, A.W., and Karlsson, H.R., 2002, Nd and Sr isotopic data from an arcroof plutonic suite and host rocks: Bear Mountain intrusive complex, Klamath Mountains, California: Geological Society of America, Abstracts with Programs, v. 34, no. 6. P. 270.

Fuis, G.S., and Zucca, J.J., 1984, A geologic cross section of northeastern California from seismic refraction results, in Nilsen, T. H., ed., Geology of the Upper Cretaceous Hornbrook Formation, Oregon and California: Society of Economic Paleontologists and Mineralogists, Pacific Section, v. 42, p. 203-209.

Fuis, G.S., Zucca, J.J., Mooney, W.D., and Milkereit, B., 1987, A geologic interpretation of seismic-refraction results in northern California: Geological Society of America Bull., v. 98, no. 1, p. 53-65.

Furlong, E.L., 1905, Preptoceras, a new ungulate from the Samwel Cave, California: California University, Publication of Geological Science, v. 4, no. 8, p. 163-169.

---1906, The exploration of Samwel Cave: American Journal of Science, series 4, v. 22, p. 235-247.

Gamer, R.L., 1952, Construction geology of tunnel no. 12, S.P.R.R.--relocation around Shasta Dam reservoir, California: Geological Society of America Bulletin, v. 63, no. 12, pt. 2, p. 1329.

Garcia, M.O., 1976, Petrology of the Rogue River area, Klamath Mountains, Oregon: problems in the identification of ancient volcanic arcs: Los Angeles, California University, Ph.D dissertation, 211 p.

---1976, Rogue River island arc complex, Western Jurassic belt, Klamath Mountains, Oregon: Geological Society of America, Abstracts with Programs, v. 8, no. 3, p. 375.

---1978, Criteria for the identification of ancient volcanic arcs: Earth-Science Reviews, v. 14, p. 147-165.

---1979, Petrology of the Rogue and Galice formations, Klamath Mountains, Oregon; identification of a Jurassic island arc sequence: Journal of Geology v. 87, no. 1, p. 29-41.

---1982, Petrology of the Rogue River island-arc complex, southwest Oregon: American Journal of Science, v. 282, no. 6, p. 783-807.

Garcia, M.O., and Jacobson, S.S., 1979, Crystal clots, amphibole fractionation and the evolution of calc-alkaline magmas: Contributions to Mineralogy and Petrology, v. 69, no. 4,p. 319-327.

Gardner, W.I., 1946, Applied engineering geology at Shasta Dam, Sacramento River, California: Geological Society of America Bulletin, v. 57, no. 12, pt. 2, p. 1195-1196.

Garvin, J.B., 1986, Digital topographic analysis of suspect terranes: Eos (American Geophysical Union Trans.), v. 67, no. 44 , p. 123

Gay, T.E., Jr., 1949, Geology of Upper Coffee Creek, Etna quadrangle, California: Berkeley, California University, M.A. thesis, 89 p.

Gay, T.E., Jr., and Aune, Q.A., 1958, Geologic map of California, Alturas Sheet--Olaf P. Jenkins edition: California Division of Mines and Geology Map Sheet, scale 1:250,000.

Gehrels, G.E., and Miller, M.M., 2000, Detrital zircon geochronologic study of upper Paleozoic strata in the eastern Klamath terrane, northern California, in Soreghan, M,J., and Gehrels, G.E. eds., Paleozoic and Triassic paleogeography and tectonics of western Nevada and northern California: Geological Society of America, Special Paper 347, p. 99-107.

Gin, G.M., and Wallin, E.T., 1994, A new interpretation for the Moffett Creek Formation, eastern 
Klamath Mountains, northern California; Geological Society of America, Abstracts with Programs, v. 26, no. 2, p 54 .

Giaramita, M.J., and Harper, G.D., 2001, Newly discovered western outlier of the Josephine ophiolite(?) on the Elk River, southern coastal Oregon: Geological Society of America, Abstracts with Programs, v. 33, no. 3, p. 51.

---2002, Lithologic, field relations, and petrographic affinities of a probable outlier of the Josephine ophiolite, Elk River area, SW Oregon: Geological Society of America, Abstracts with Programs, v. 34, no. 5, p. A-22.

Godchaux, M.M., 1969, Petrology of the Greyback Igneous Complex and contact aureole, Klamath Mountains, southwestern Oregon: Eugene, Oregon University, Ph.D. dissertation, 249 p.

Godchaux, M.M., and Kays, M.A., 1969, Petrology of the Greyback intrusive complex and contact aureole, southwestern Oregon: Geological Society of America, Cordilleran Section, 65th Annual Meeting, Program, Eugene, Oregon, pt. 3, p. 18-19.

Godfrey, N.J., 1996, Ophiolitic basement of the Great Valley forarc basin, California, from seismic and gravity data: Impliations for crustal growth at the North American continental margin: Geological Society of America, Abstracts with Programs, v. 28, no. 5, p 69.

Goldstein, H.L., 1998, A continuation of the La Grange fault, eastern Klamath Mountains, California: Arcata, California, Humboldt State University, B.Sc. Thesis, 22 p.

Goodge, J.W., 1985, Widespread blueschist assemblages in the Stuart Fork terrane, central Klamath Mountains, northern California: Geological Society of America, Abstracts with Programs, v. 17, no. 6, p. 357.

---1986, Relations of Stuart Fork and North Fork terranes in the central Klamath Mountains, northern California: Geological Society of America, Abstracts with Programs, v. 18, no. 2, p. 109.

---1987, Polyphase metamorphism of Early Mesozoic oceanic rocks in the central Klamath Mountains, California: Geological Society of America, Abstracts with Programs, v. 19, no. 6, p. 382.

---1987, Polyphase metamorphic evolution of the Stuart Fork terrane, a Late Triassic subduction complex in the Klamath Mountains, northern California: Los Angeles, University of California, Ph.D. dissertation, 228 p.

---1989, Polyphase metamorphism of the Stuart Fork terrane, a Late Triassic subduction complex, Klamath Mountains, northern California: American Journal of Science, v. 289, p. 874-943.

---1989, Evolving early Mesozoic convergent margin deformation, central Klamath Mountains, northern California: Tectonics, v. 8, p. 845-864.

---1990, Tectonic evolution of a coherent Late Triassic subduction complex, Stuart Fork terrane, Klamath Mountains, northern California: Geological Society of America Bull., v. 102, no. 1, p. 86-101.

---1992, Cogenetic Permo-Triassic melange and blueschist terranes of the central cordillera, California and Oregon: Geological Society of America, Abstracts with Programs, v. 24, no. 5, p. 27.

---1995, Pre-Middle Jurassic accretionary metamorphism in the southern Klamath Mountains of northern California, USA: Journal of Metamorphic Geology, v. 13, p. 93-110.

Goodge, J.W., and Hacker, B.R., 1989, Margin-parallel variation in lower Mesozoic North American cordilleran subduction complexes: Geological Society of America, Abstracts with Programs, v. 21, no. 5 , p. 85.

Goodge, J.W., and Renne, P.R., 1991, Mid-Paleozoic petrotectonic signature of accretionary belts in the southern Klamath Mountains, California: Geological Society of America, Abstracts with Programs, v. 23, no. 5, p. 480.

---1993, Mid-Paleozoic olistoliths in the eastern Hayfork terrane melange, Klamath Mountains: Implications for late Paleozoic-early Mesozoic Cordilleran forearc development: Tectonics, v. 12, no. 1 , p. 279-290.

Goodwin, J. G., 1957, Lead and zinc in California: California Journal of Mines and Geology, v. 53, p. 353-724.

Gordon, M., Jr., 1966, An Upper Triassic bactritoid cephalopod from California: Journal of Paleontology, v. 40 , no. 5, p. $1220-1222$.

Gorman, C.M., 1985, Geology, geochronology, and geochemistry of the Rattlesnake Creek terrane, west-central Klamath Mountains, California: Salt Lake City, University of Utah, M. S. thesis, $112 \mathrm{p}$.

Goullaud, L., 1973, Petrology and structure of a gabbroic body in the Trinity ultramafic pluton, Klamath Mountains, California: Seattle, University Washington, M.S. thesis, $54 \mathrm{p}$.

---1975, Structure and petrology in the Trinity mafic-ultramafic complex, Klamath Mountains, northern 
California: Geological Society of America, Abstracts with Programs, v. 7, no. 3, p. 321.

---1977, Structural synthesis of the Trinity mafic-ultramafic complex in the Coffee Creek area,

Klamath Mts., CA: Geological Society of America, Abstracts with Programs, v. 9, no. 4, p. 423-424.

---1977, Structure and petrology in the Trinity mafic-ultramafic complex, Klamath Mountains, northern California, in Lindsly-Griffin, Nancy, and Kramer, J. C., eds., Guidebook to the geology of the Klamath Mountains, northern California: Geological Society of America, Cordilleran Section, 73rd Annual Meeting, Sacramento, California, Guidebook, p. 112-133.

---1978, Petrology and structure of the gabbroic body in the Trinity ultramfic pluton, Klamath Mountains, California: Seattle, Washington, University of Washington, Ph.D. thesis, $61 \mathrm{p}$.

Grady, K.A., 1990, Geology and structure of the rocks associated with the basal (Madstone) thrust of the Josephine ophiolite in southwestern Oregon; evidence for a metamorphic sole: Albany, University of New York, M.Sc. thesis, 160 p.

Grady, K.A., Harper, G.D., and Heizer, M., 1989, N-NE obduction of the Josephine Ophiolite along an amphibolite sole, SW Oregon: Geological Society of America Abstracts With Programs, v. 21, no. 5, p. 86.

Graton, L.C., 1910, The occurrence of copper in Shasta County, California: U.S. Geological Survey Bulletin 430-B, p. 71-111.

Grau, G., Lécuyer, C., Bernard-Griffiths, J., and Morin, N., 1991, Origin and petrogenesis of the Trinity ophiolite complex (California), new constraints from REE and Nd isotope data, in Menzies, M.A., Dupuy, C., and Nicolas, A., eds., Orogenic lherzolites and mantle processes: Journal of Petrology, Special Volume, p. 229-242.

Gray, F., 1980, Lherzolitic and wehrlitic rock series at Tincup Peak, Klamath Mountains, southwestern Oregon: Geological Society of America, Abstracts with Programs, v. 12, no. 3, p. 108.

---1980, Geology of the igneous complex at Tincup Peak, Kalmiopsis Wilderness Area, southwestern Oregon: U. S. Geological Survey Open-file Report 80-1243, 77 p., scale 1:12,000.

---1981, Geology of the igneous complex at Tincup Peak, Kalmiopsis Wilderness Area, southwestern Oregon: University of Massachusetts, M. S. thesis, $72 \mathrm{p}$.

Gray, F., and Hamilton, M., 1983, North Fork Smith River Roadless Area, California and Oregon, in Wilderness Mineral Potential, S. P. Marsh and others, eds.: U.S. Geological Survey Professional Paper 1300, v. 1, p. 315-318.

Gray, F., and McKee, E.H., 1981, New K-Ar dates from the Wild Rogue Wilderness, Southwestern Oregon: ISOCHRON/WEST, no. 32, p. 27-29.

Gray, F., and Miller, M.S., 1983, Wild Rogue Wilderness, Oregon, in Marsh, S. P., Kropschott, S. J., and Dickinson, R. G., Wilderness Mineral Potential: Assessment of mineral-resource potential in U. U., Forest Service Lands studied 1964-1984: U. S. Geological Survey Professional Paper 1300, v. 2, p. 914-916.

Gray, F., Miller, M.S., Gaps, R.S., Peterson, J.A., Blakely, R.J., and Senior, L., 1982, Mineral resource potential map of the Wild Rogue Wilderness, Coos and Curry Counties, Oregon: U.S. Geological Survey Miscellaneous Field Studies Map MF-1318-D, scale 1:48,000.

Gray, F., and Page, N.J., 1985, Geologic map of the Lower Coon Mountain pluton, Del Norte County, California: U.S. Geological Survey Open File Report 85-148, scale 1:24,000.

Gray, F., Page, N.J., Carlson, C.A., Wilson, S.A., and Carlson, R.R., 1986, Platinum-group element geochemistry of zoned ultramafic intrusive suites, Klamath Mountains, California and Oregon, in L. J. Cabri, ed., A third issue devoted to platinum deposits: Economic Geology, v. 81, no. 5, p. 1252-1260.

Gray, F., Page, N.J., Hamilton, M.M., Buchler, A.R., and Gabby, P.N., 1983, Mineral resource potential maps of the North Fork Smith River Roadless Areas, Del Norte County, California, and Curry and Josephine Counties, Oregon: U.S. Geological Survey, Miscellaneous Field Studies Map MF-1423-B, with text, $22 \mathrm{p}$.

Gray, F., and Peterson, J.A., 1982, Geochemical analyses of rock and stream sediment samples from the Wild Rogue wilderness area, Coos, Curry, and Douglas Counties, Oregon: U.S. Geological Survey Open-File Report, no. 82-0186, 24 p.

Gray, F., Ramp, L., Moring, B., Douglas, I, and Donahoe, J., 1982, Geologic map of the Wild Rogue Wilderness, Coos, Curry, and Douglas Counties, Oregon: U.S. Geological Survey, Miscellaneous Field Studies Map MF-1381-A, scale 1:48,000.

Gray, G.G., 1983, A kinematic analysis of thrust faulting, west-central Klamath Mountains, California: Geological Society of America, Abstracts with Programs, v. 15, no. 6, p. 585. 
---1985, Structural, geochronologic, and depositional history of the western Klamath Mountains, California and Oregon: Implications for the early to middle Mesozoic tectonic evolution of the western North American Cordillera: Austin, University of Texas, Ph. D. dissertation, 162 p.

---1985, Native terranes: Examples from the Cordillera: Geological Society of America, Abstracts with Programs, v. 17, no. 7, p. 597.

---1986, Native terranes of the central Klamath Mountains, California: Tectonics, v. 5, p. 1043-1054.

Gray, G.G., and Petersen, S.W., 1982, Northward continuation of the Rattlesnake Creek terrane, north-central Klamath Mountains, California: Geological Society of America, Abstracts with Programs, v. 14, no. 4, p. 167.

Gray, G.G., and Wright, J.E., 1984, Nature and tectonic setting of the Rattlesnake Creek terrane, west-central Klamath Mountains, California: Geological Society of America, Abstracts with Programs, v. 16, no. 6, p. 524.

Gribble, R.F., and Barnes, C.G., 1987, The composite Ashland pluton: Evidence for multiple felsic magmas in a tilted pluton, Klamath Mtns, CA and OR: Geological Society of America Abstracts with Programs, v. 19, no. 6, p. 383-384.

Gribble, R.F., Barnes, C.G., Donato, M.M., Hoover, J.D., and Kistler, R.W., 1990, Geochemistry and intrusive history of the Ashland pluton, Klamath Mountains, California and Oregon: Journal of Petrology, v. 31, pt. 4, p. 883-923.

Griesau, N.E., 1992, A kinematic study of the Summit Valley plutonic complex, Klamath Mountains, California: Albany, State University of New York, M.Sc. thesis 133 p.

Griesau, N.E., and Harper, G.D., 1992, Deformation of a Late Jurassic plutonic complex intruding the Orleans thrust, west-central Klamath Mountains, California: Geological Society of America, Abstracts with Programs, v. 24, no. 5, p. 28.

Griscom, A., 1972, An aeromagnetic survey and interpretation, in Hotz, P.E., Thurber, H.K., Marks, L.Y., and Evans, R.K., Mineral resources of the Salmon-Trinity Alps primitive area, California: U.S. Geological Survey Bulletin 1371-B, p. B44-B47.

---1973, Bouguer gravity map of California-Redding Sheet: California Division of Mines and Geology, scale 1:250,000, text 13 p.

---1977, Aeromagnetic and gravity interpretation of the Trinity ophiolite complex, northern California: Geological Society of America, Cordilleran Section, 73rd Annual Meeting, Program, Sacramento, California, v. 9, no. 4, p. 426-427.

---1980, Klamath Mountains Province, in Oliver, H. W., ed., Interpretation of the gravity map of California and its continental margin,: California Division of Mines and Geology Bulletin, v. 205, p. 34-36.

---1984, A magnetic interpretation of the Josephine Peridotite, Del Norte County, California: U. S. Geological Survey Bulletin 1546-C, p. 53-63, scale 1:62,500.

Griscom, A.E., Roberts, C.W., and Halvorson, P.F., 1993, Tectonic significance of magnetic and gravity data across northern California (Lat. $39^{\circ} \mathrm{N}$. to Lat. $41^{\circ} \mathrm{N}$.): Geological Society of America, Abstracts with Programs, v. 25, no. 5, p. 44.

Gronewold, R.L., 1983, Trace and major element geochemistry of the Grey Eagle volcanogenic massive sulfide deposit, Siskiyou County, California: Davis, University of California, M.S. thesis, 154 p.

Gronewold, R.L., and Taylor, B.E., 1983, Major and trace element zonation about the Gray Eagle Cu-Zn deposit: indications for the geothermal conduit: Geological Society of America, Abstracts with Programs, v. 15, no. 5, p. 298.

Gronewold, R.L., Cramer, R.S., and Taylor, B.E., 1983, Au-bearing gossan at the Gray Eagle Cu-Zn massive sulfide deposit, Siskiyou County, California: Geological Society of America, Abstracts with Programs, v. 15, no. 5, p. 298.

Groo, T.S., 1982, Speleogenesis in Marble Cave; Trinity County, California: The Speleograph, v. 18, no. 5 , p. 60-66.

Grover, T.W., 1984, Progressive metamorphism west of Condrey Mountain dome, north-central Klamath Mountains, northern California: Eugene, University of Oregon, M.S. thesis, 129 p.

Grover, T.W., and Rice, J.M., 1985, A progressive metamorphic sequence west of the Condrey Mountain dome, west-central Klamath Mountains, California: Geological Society of America, Abstracts with Programs, v. 17, no. 6, p. 358.

Gude, A.J., III, and Sheppard, R.A., 1969, Hydrous sodium silicate minerals, Trinity County, California: Geological Society of America Abstracts with Programs 1969, pt. 7, p. 86. 
---1972, Silhydrite, $3 \mathrm{Si}_{2} \mathrm{H}_{2} \mathrm{O}$, a new mineral from Trinity County, California: American Mineralogist, v. 57, no. 7-8, p. 1053-1065.

Gullixson, C.F., Bounds, J. D., and Benson, G. T., 1980, Igneous rocks near Marial, Rogue River, southwestern Oregon: Geological Society of America, Abstracts with Programs, v. 12, no. 3, p. 108-109.

Gunther, C.G., 1905, An interesting fault system New York mine, Siskiyou County, California: Engineering and Mining Journal, v. 80, p. 1013.

Gustin, M.M., and Eastoe, C.J., 1986, Geology and mineralization of the Bully Hill area, East Shasta district, California: Geological Society of America, Abstracts with Programs, v. 18. no. 2, p. 112.

Gustin, M.M., and Eastoe, C.J., 2000, Geology and ore petrography of Permian Kuroko-type volcanogenic massive sulfide deposits of the Bully Hill area, East Shasta district, California: Economic Geology, vol. 95, p. 343-360.

Hacker, B.R., 1989, Conditions and sequence of metamorphism of high-MgO volcanic rocks in the Hayfork/North Fork terranes, Sawyers Bar area, central Klamath Mountains: Geological Society of America, Abstracts with Programs, v. 21, no. 5, p. 87.

Hacker, B.R., Donato, M.M., Barnes, C.G., McWilliams, M.O., and Ernst, W.G., 1995, Timescales of orogeny: Jurassic construction of the Klamath Mountains: Tectonics, v. 14, no. 3, p. 677-703.

Hacker, B.R., Donato, M.M., and Ernst, W.G., 1992, Jurassic synmagmatic normal fault in the central Klamath Mountains: Geological Society of America, Abstracts with Programs, v. 24, no. 5, p. 29.

Hacker, B.R., Donato, M.M., and McWilliams, M.O., 1993, New geochronologic constraints on Early, Middle, and Late Jurassic orogenesis in the Klamath Mountains: Geological Society of America, Abstracts with Programs, v. 25, no. 5, p. 46.

Hacker, B.R., and Ernst, W.G., 1990, Metamorphism and metasomatism of high-MgO greenstone in the central Klamath Mountains: Geological Society of America, Abstracts with Programs, v. 22, no. 3, p. 27.

---1991, Permian-Jurassic evolution of Hayfork, Salmon River, North Fork, and Stuart Fork terranes, Klamath Mountains: Geological Society of America, Abstracts with Programs, v. 23, no. 2, p. 32.

---1992, Preliminary metamorphic map of the Klamath Mountains, NW California and SW Oregon: Geological Society of America Abstracts with Programs, v. 24, no. 7, p. 292.

---1993, Jurassic orogeny in the Klamath Mountains: A geochronological analysis, in Dunn, G., and McDougall, K., Mesozoic Paleogeography of the Western United States: Society of Economic Paleontologists and Mineralogists, Pacific Section, Book 71, p. 37-60.

Hacker, B.R., Ernst, W.G., and Barton, M.D., 1992, Metamorphism, geochemistry, and origin of magnesian volcanic rocks, Klamath Mountains, California: Journal of Metamorphic Geology, v. 10, p. 55-69.

Hacker, B.R., Ernst, W.G., and McWilliams, M.O., 1993, Genesis and evolution of a Permian-Jurassic magmatic arc/accretionary wedge, and reevaluation of terranes in the central Klamath Mountains: Tectonics, v. 12, no. 2, p. 387-409.

Hacker, B.R., and Goodge, J.W., 1990, Comparison of early Mesozoic high-pressure rocks in the Klamath Mountains and Sierra Nevada, in Harwood, D.S., and Miller, M.M., eds., Paleozoic and early Mesozoic paleogeographic relations; Sierra Nevada, Klamath Mountains, and related terranes; Geological Society of America Special Paper 255, p.277-295.

Hacker, B.R., and Peacock, S.M., 1990, Comparison of the Central Metamorphic belt and Trinity terrane of the Klamath Mountains with the Feather River terrane of the Sierra Nevada, in Harwood, D.S., and Miller, M.M., eds., Paleozoic and early Mesozoic paleogeographic relations; Sierra Nevada, Klamath Mountains, and related terranes; Geological Society of America Special Paper 255, p.75-92.

Hackman, D.B., 1971, Origin and environment of mineralization at the Siskon Mine, Siskiyou County, California: Tucson, Arizona University, M.S. thesis, 52 p.

Haessig, P.A., 1988, Structure and petrography of the schist of Skookum Gulch, Callahan-Yreka area, eastern Klamath Mountains, northern California: Corvallis, Oregon, Oregon State University, M.Sc. thesis, 169 p.

---1989, Field relations and structure of the schist of Skookum Gulch, an early Paleozoic melange, Callahan-Yreka area, eastern Klamath Mountains: Geological Society of America, Abstracts with Programs, v. 21, no. 5, p. 88.

Haessig, P.A., De La Fuente, J., Rose, E.K., Burkhart, L., and Hilton, S., 2002, Abandoned mine reclamation of sediment tailings at King Solomon Mine, Klamath National Forest, California: 
Geological Society of America, Abstracts with Programs, v. 34, no. 5, p. A-109.

Haessig, P.A., Potter, A.W., Wallin, E.T., and Mattinson, J.M., 1987, Early Cambrian tonaliteplagiogranite from the Yreka-Callahan-Gazelle area, eastern Klamath Mountains, northern California: Geological Society of America, Abstracts with Programs, v. 19, no. 7, p. 689.

Haley, C.S., 1923, Gold placers of California: California State Mining Bureau Bulletin 92, 167 p.

Hall, F.H., 1893, Ancient gravels, Siskiyou County: Mining and Science Press, v. 66, p. 85.

Halliday, W.R., 1962, Caves of California: A special report of the Western Speleological Survey in cooperation with the National Speleological Society, Copyright 1962 by William R. Halliday, Seattle, Washington.

---1963, Considerations of the use of Oregon Cave as a fallout shelter: Western Speleol. Survey Misc. Ser. Bull. 9, W.S.S. Serial No. 27, April.

---1963, Basic speleological considerations of Oregon Cave: Western Speleol. Survey Misc. Ser. Bull. No. 13, W.S.S., Serial No. 32, December.

---1967, Geology of Oregon Cave: National Speleological Society Bulletin, v. 29, no. 3, p. 98.

---1969, Oregon Cave, Klamath Mountains, Oregon: National Speleological Society Bulletin, v. 31, no. 2, p. 23-31.

Halliday, W.R., and Walsh, F K., 1976, Oregon caves; discovery \& exploration; Oregon Caves National Monument, 2nd edition, Te-Cum-Tom Publications, Grants Pass, Oregon, 27 p.

Hamilton, F., 1922, California mineral resources and the State Mining Bureau (cadmium): California State Mining Bureau Report 18, p. 241.

Hamilton, M.M., Beulher, A.R., Alan, R., and Gabby, P.N., 1983, Mineral investigation of the North Fork Smith RARE II Area (nos. 5707 and 6707), Del Norte County, California; Curry and Josephine Counties, Oregon: U.S. Bureau of Mines, Report No. MLA 92-83, 41 p., scale of map 1:63,360.

Hamilton, P., 1979, Mining history made on Coffee Creek, Trinity County, California: California Mining Journal, v. 49, no. 1, p. 4-5.

Hamilton, W., 1969, Mesozoic California and the underflow of Pacific mantle: Geological Society of America Bulletin, v. 80, no. 12, p. 2409-2430.

---1978, Mesozoic tectonics of the western United States, in Mesozoic paleogeography of the western United States, Howell, D.G., and McDougall, K.A., eds.: Society of Economic Paleontologists and Mineralogists, Pacific Section, Pacific Coast Paleogeography symposium 2, p. 33-70.

Hanks, C.L., 1981, The emplacement history of the Tom Martin ultramafic complex and associated metamorphic rocks, north-central Klamath Mountains, California: Seattle, University of Washington, M. S. thesis, $112 \mathrm{p}$.

---1981, Thrusting of the western Triassic and Paleozoic belt in the north central Klamath Mountains, California: The relationship of the Tom Martin ultramafic complex to adjacent metamorphic rocks: Geological Society of America, Abstracts with Programs, v. 13, no. 2, p. 58.

Hanks, H.G., 1870, Diamonds in California: Mining and Science Press, v. 20, no. 11, March 12, p. 162.

---1870, Diamonds in California: Mining and Science Press, v. 21, August 20, p. 122.

---1884, Quicksilver: California State Mining Bureau Report 4, 410 p.

Harbaugh, J.W., 1955, Stratigraphy and paleontology of portions of the Klamath Mountains, California: Madison, Wisconsin University, Ph.D. dissertation, 130 p.

---1974, Geology field guide to northern California: W. C. Brown Co., Dubuque, Iowa, 123 p.

Harden, D.R., 1997, The Klamath Mountains: Accreted terranes and a view of the mantle, Chapter 9, in California Geology: Prentice Hall. Inc., p. 194-204.

Harder, E.C., 1910, Some chromite deposits in western and central California: U.S. Geological Survey Bulletin 430, p. 167-183.

Harding, D.J., 1988, Josephine peridotite tectonites; a record of upper mantle plastic flow: Ithica, New York, Cornell University, Ph.D. dissertation, $352 \mathrm{p}$.

Harding, D.J., and Bird, J.M., 1983, Accreting plate margin structures in the Josephine Ophiolite tectonite and cumulate sequences: Eos (American Geophysical Union Trans.), v. 64, no. 45, p. 846.

Harper, G.D., 1978, Preliminary report on the western Jurassic belt, Klamath Mountains, vicinity of the Smith river, northwestern California: Geological Society of America, Cordilleran Section, 74th Annual Meeting, Program, Tempe, Arizona, v. 10, no. 3, p. 108.

---1979, "Anomalous" ophiolite underlying Late Jurassic metasedimentary rocks of the Galice Formation, western Jurassic belt, northwestern California: Geological Society of America, Abstracts with Programs, v. 11, no. 3, p. 82.

---1980, Structure and petrology of the Josephine Ophiolite and overlying metasedimentary rocks, 
northwestern California: Berkeley, California University Ph.D dissertation, 281 p.

---1980, The Josephine Ophiolite; remains of a Late Jurassic marginal basin in northwestern California: Geology, v. 8, no. 7, p. 333-337.

---1981, Structural history of the Josephine Ophiolite and overlying flysch, western Jurassic belt, NW

California: Geological Society of America, Abstracts with Programs, v. 13, no. 2, p. 59.

---1982, Evidence for large-scale rotations at spreading centers from the Josephine Ophiolite: Tectonophysics, v. 82, no. 1-2, p. 25-44.

---1982, Geochemistry of dikes and lavas of the Josephine ophiolite, Klamath Mountains, California: Eos (American Geophysical Union Trans.), v. 63, no. 45, p. 1133.

---1982, Inferred high primary volatile contents in lavas erupted in an ancient back-arc basin, California: Journal of Geology, v. 90, no. 2, p. 187-194.

---1983, A depositional contact between the Galice Formation and a Late Jurassic ophiolite in northwestern California and southwestern Oregon: Oregon Geology, v. 45, no. 1, p. 3-7.

---1983, The Nevadan orogeny--collapse of a west-facing island arc/back-arc/ remnant arc complex: Geological Society of America, Abstracts with Programs, v. 15, no. 5, p. 294.

---1984, Tectonic setting of the Josephine ophiolite, Oregon and California (USA), in Ophiolites through time: Ofioliti, Abstracts, 3rd Annual Meeting, November 13-15, Nancy, Supplement to v. 9, p. 30.

---1984, The Josephine ophiolite, northwestern California: Geological Society of America Bulletin, v. 95, p. 1009-1026.

---1985, Tectonic setting of the Josephine ophiolite, California and Oregon (USA): Ofioliti, v. 10, no. 23, p. 307-316.

---1985, Tectonics of slow spreading mid-ocean ridges and consequences of a variable depth to the brittle/ductile transition: Tectonics, v. 4, no. 4, p. 395-409.

---1988, Episodic magma chambers and amagmatic extension in the Josephine ophiolite: Geology, v. 16, no. 9, p. 831-834.

---1988, Reaction-enhanced permeability by formation of epidosites in seafloor hydrothermal systems: American Geophysical Union EOS Transactions, v. 69, p. 527.

---1989, Field guide to the Josephine Ophiolite and coeval island arc complex, Oregon-California, in Aalto, K.R., and Harper, G.D., leaders, Geologic evolution of the northernmost Coast Ranges and western Klamath Mountains, California: 28th International Geological Congress, Field Trip Guidebook T308, p. 2-20, American Geophysical Union, Washington, D. C.

---1992, Contrasting thrust directions along the roof and basal thrusts of the Josephine-Galice subterrane, western Klamath Mountains: Geological Society of America, Abstracts with Programs, v. 24, no. 5, p. 31.

---1995, Pumpellyosite and prehnitite associated with epidosite in the Josephine ophiolite--Ca metasomatism during upwelling of hydrothermal fluids at a spreading axis, in Schiffman, Peter, and Day, H. W., eds., Low-grade metamorphism of mafic rocks: Geological Society of America Special Paper 296, p. 101-122.

---1999, Tectonic implications of multiple magma types and Fe-Ti basalts in the Josephine ophiolite, NW Californnia: Geological Society of America, Abstracrs with Programs, v. 31, no. 6, p. 61.

---1999, Synorogenic Late Jurassic calc-alkaline to intrusives in the western Klamath terrane, Klamath Mountains, northwestern California: Geological Society of America, Abstracts with Programs, v. 31, no. 6,p. 61

---2002, A Lau Basin model for the formation of the Josephine ophiolite and related rift facies, Klamath Mountains, Oregon-California: Geological Society of America, Abstracts with Programs, v. 34, no. 5, p. A-22.

---2003, Fe-Ti basalts and propagating-rift tectonics in the Josephine Ophiolite: Geological Society of America Bull., v.115, no. 7, p. 771-787.

Harper, G.D., and Alexander, R.J., 1990, The Josephine ophiolite: Hydrothermal metamorphism at a slow-spreading ridge: Eos (American Geophysical Union Trans.), v. 71, no. 43, p. 1647.

---1991, Growth faulting and tilting in the extrusive sequence of the Josephine ophiolite: Implications for recognition of crustal tilting at oceanic spreading centers: Eos (American Geophysical Union Trans.), v. 72, no. 44 , p. 456.

---1993, Two styles of mineralization in the Josephine Ophiolite related to near- axis thermal discharge, California-Oregon: Geological Society of America Abstracts with Programs, v. 25, no. 6, p. $79-80$. 
Harper, G.D., Bowman, J.R., and Kuhns, R., 1988, A field, chemical, and stable isotope study of subseafloor metamorphism of the Josephine ophiolite, California-Oregon: Journal of Geophysical Research, v. 93, p. 4625-4656.

Harper, G.D., and Coulton, A.J., 1993, Where is the paleo-Moho in Ophiolites?: EOS Transactions, American Geophysical Union, 1993 Fall Meeting, v. 74, no. 43, p. 660-661.

Harper, G.D., Grady, K., and Wakabaishi, J., 1990, A structural study of a metamorphic sole beneath the Josephine ophiolite, western Klamath terrane, California-Oregon, in Harwood, D.S., and Miller, M.M., eds., Paleozoic and erly Mesozoic paleogeographic relations; Sierra Nevada, Klamath Mountains, and related terranes; Geological Society of America Special Paper 255, p. 379-396.

Harper, G.D., and Harding, D., 1986, Comment on "Structural study of intra-oceanic thrusting in the Klamath Mountains, northern California: implications on accretion geometry" by Mathilde Cannat and Francoise Boudier: Tectonics, v. 5, no. 4, p. 687-692.

Harper, G.D., Heizler, M., and Roden-Tice, M., 1996, Preliminary Cretaceous thermochronology of the western Klamath Mountains, Oregon-California: Geological Society of America, Abstracts with Programs, v. 28, no. 5, p. 72

Harper, G.D., Norman, E.A., and Jones, D.L., 1983, The Lems Ridge olistostrome--sediment fill of an ancient fracture zone: Geological Society of America, Abstracts with Programs, v. 15, no. 5, p. 427.

Harper, G. D., and Park, R., 1986, Comment, in Comments and Reply on "Paleomagnetism of the Upper Jurassic Galice Formation, southwestern Oregon: Evidence for differential rotation of the eastern and western Klamath Mountains": Geology, v. 14, no. 12, p. 1049-1050.

Harper, G.D., and Saleeby, J.B., 1980, Zircon ages of the Josephine Ophiolite and the lower Coon Mountain Pluton, western Jurassic belt, NW California: Geological Society of America, Abstracts with Programs, v. 12, no. 3, p. 109-110.

Harper, G.D., Saleeby, J.B., Cashman, S., and Norman, E., 1986, Isotopic age of the Nevadan orogeny in the western Klamath Mountains, California-Oregon: Geological Society of America, Abstracts with Programs, v. 18, no. 2, p. 114.

Harper, G.D., Saleeby, J.B., and Heizler, M., 1994, Formation and emplacement of the Josephine ophiolite and the Nevadan orogeny in the Klamath Mountains, California-Oregon: $\mathrm{U} / \mathrm{Pb}$ 40Ar/39Ar geochronology: Journal of Geophysical Research, v. 99, no. B3, p. 4293-4321.

Harper, G.D., Saleeby, J.B., and Norman, E.A.S., 1985, Geometry and tectonic setting of sea-floor spreading for the Jopsephine ophiolite, and implications for Jurassic accretionary events along the California margin, in D.G. Howell, ed., Tectonostratigraphic terranes of th circum-Pacific region: Circumpacific Council for Energy and Mineral Resources, Earth Science Series No. 1, p. 239-257.

Harper, G.D., Saleeby, J.B., and Sharp, W.D., 1983, Late Jurassic transform motion in the western U. S.: Eos (American Geophysical Union Trans.), v. 64, no. 45, p. 846.

Harper, G.D., Saleeby, J.B., Pessagno, E.A., Jr., and Heizler, M., 1989, The Josephine ophiolite; Generation, translation, and emplacement of Late Jurassic parautochthonous back-arc lithosphere, Klamath Mountains, California-Oregon: Geological Society of America Abstracts with Programs, v. 21, no. 6, p. 28.

Harper, G.D., and Wright, J.E., 1984, Middle to Late Jurassic tectonic evolution of the Klamath Mountains, California-Oregon: Tectonics, v. 3, no. 7, p. 759-772.

Harris, A.D., 1978, Klamath River geology, Curley Jack Camp to Ti Bar, Siskiyou County, California: California Geology, v. 31, no. 5, p. 108-114.

---1979, Geology along the Klamath River between Curley Jack Camp and Ti Bar, Siskiyou County, California: Geological Society of America, Abstracts with Programs, v. 11, no. 3, p. 82.

Harwood, D.S., and Miller, M.M., eds., 1990, Paleozoic and early Mesozoic paleogeographic relations; Sierra Nevada, Klamath Mountains, and related terranes: Geological Society of America, Special Paper 255, $422 \mathrm{p}$.

Hassemer, J.R., 1983, Some preliminary findings of a reconnaissance geochemistry study, West Shasta district, California: U.S. Geological Survey Open-File Report 83-0057, 16 p

Hassemer, J.R., Silberman, M.L., and Hopkins, R.T., 1992, Analytical results and sample locality map of rock samples from the Hayfork $30^{\prime} X 1^{\circ}$ Quadrangle (northwest quarter of the Redding $1^{\circ} \times 2^{\circ}$ Quadrangle), Humboldt and Trinity counties, California: U.S. Geological Survey Open-file Report 92-0210-A, 74 p, map scale 1:100,000: Also available as U.S. Geological Survey Open-file Report 92-0210-B, 5 1/ 4 inch diskette.

---1992, Analytical results and sample locality map of rock samples from the Garberville $30^{\prime} X 1^{\circ}$ 
Quadrangle (southwest quarter of the Redding $1^{\circ} \times 2^{\circ}$ Quadrangle), Humboldt, Trinity, Shasta, Tehama, and Mendocino counties, California: U.S. Geological Survey Open-file Report OF 92-0316-A, 67 p, map scale 1:100,000: Also available as U.S. Geological Survey Open-file Report 92-0316-B, 5 1/ 4 inch diskette.

Hausmann, A., and Kruttschnitt, J., Jr., 1908, Shasta County [p. 38-114], Siskiyou County [p. 120-133], Del Norte County [p. 133-140], and Trinity County [p. 140-150], in The copper resources of California: California State Mining Bureau, Bulletin 50.

Heiken, G., 1976, Depressions surrounding volcanic fields; A reflection of underlying batholiths?: Geology, v. 4, no. 9, p. 568-572.

Heinrich, M.A., 1966, The geology of the Applegate Group (Triassic) in the Kinney Mountain area, southwest Jackson County, Oregon: Eugene, Oregon University, M.S. thesis, 101 p.

Helley, E.J., and LaMarche, V.C., Jr., 1972, December 1964, a 400-year flood in northern California, in Man and His Physical Environment: Readings in Environmental Geology: Burgess Publishing Company, Minneapolis, Minnesota, p. 56-58.

---1973, Historic flood information for northern California streams from geological and botanical evidence: U.S. Geological Survey Professional Paper 485-E, 16 p.

Helming, B.H., 1966, Petrology of the Rogue Formation, southwestern Oregon: Eugene, University of Oregon, M.S. thesis, $82 \mathrm{p}$.

Helper, M.A., 1983, Deformation-metamorphism in a regional blueschist-greenschist facies terrane, Condrey Mt. Schist, north-central Klamath Mountains, Northern California: Geological Society of America Abstracts with Programs, v. 15, no. 5, p. 427.

---1985, Structural, metamorphic and geochronologic constraints on the origin of the Condrey Mountain Schist, north central Klamath Mountains, northern California: Austin, University of Texas, Ph.D. dissertation, 209 p.

---1986, Age and direction of thrusting along the western margin of the Condrey Mountain window, Klamath Mtns., California: Geological Society of America, Abstracts with Programs, v. 18, no. 2, p. 116.

---1986, Deformation and high P/T metamorphism in the central part of the Condrey Mountain window, north-central Klamath Mountains, California and Oregon: Geological Society of America Memoir 164, p. 125-141.

---1986, Early Cretaceous metamorphic ages for high P/T schists in the Condrey Mountain window, Klamath Mountains, California and Oregon: An outlier of Franciscan?: Geological Society of America, Abstracts with Programs, v. 18, no. 6, p. 634.

---1992, Evidence for successive Late Jurassic-Early Cretaceous underplating during high P/T metamorphism of the Condrey Mountain Schist, central Klamath Mts., Calif. and Oregon: Geological Society of America, Abstracts with Programs, v. 24, no. 5, p. 33.

Helper, M.A., Walker, N.W., and McDowell, F.W., 1988, U-Pb and K-Ar age constraints for Late Jurassic-Early Cretaceous deformation in the central Klamath Mtns., NW California and SW Oregon: Geological Society of America Abstracts With Programs, v. 20, No. 7, p. 231-232.

---1989, Early Cretaceous metamorphic ages and Middle Jurassic U-Pb zircon protolith ages for the Condrey Mountain Schist, Klamath Mtns., NW Calif. and SW Oregon: Geological Society of America, Abstracts with Programs, v. 21, no. 5, p. 92.

Henry, D.J., and Medaris, G.L., 1976, Application of pyroxene and olivine-spinel geothermometers to the alpine peridotites in southwestern Oregon: Geological Society of America, Abstracts with Programs, v. 8, no. 6, p. 913-914.

Hershey, O.H., 1897, A "pocket" horizon in Trinity County, California: Mining and Science Press, no. 75 , p. 549.

---1899, Origin and age of certain gold "pocket" deposits in northern California: American Geologist, v. 24, p. 38-43.

---1899, The upper Coffee Creek mining district, Trinity and Siskiyou Counties, California: Mining and Scientific Press, v. 79, p. 689.

---1900, Gold-bearing lodes of the Sierra Costa Mountains in California: American Geologist, v. 25, p. 76-96.

---1900, Ancient alpine glaciers of the Sierra Costa Mountains in California: Journal of Geology, no. 8, p. 42-57.

---1900, Granites of the Sierra Costa Mountains in California: Science, no. 11, p. 130-132.

---1901, Metamorphic formations of northwestern California: American Geologist, v. 27, p. 225-245. 
---1901, On the age of certain granites in the Klamath Mountains [abs.]: Journal of Geology, v. 9, p. 7677.

---1902, Neocene deposits of the Klamath region, California: Journal of Geology, no. 10, p. 377-392.

---1902, The significance of certain Cretaceous outliers in the Klamath region, California: American Journal of Science, v. 4, no. 14, p. 33-37.

---1902, A supposed early Tertiary peneplain in the Klamath region, California: Science, no. 15, p. 951-954.

---1903, Some evidence of two glacial stages in the Klamath Mountains in California: American Geologist, v. 31, p. 139-156.

---1903, Structure of the southern portion of the Klamath Mountains, California: American Geologist, v. 31, p. 231-245.

---1903, The Sierran valleys of the Klamath region, California: Journal of Geology, v. 11, p. 155-165.

---1903, The relation between certain river terraces and the glacial series in northwestern California: Journal of Geology, v. 11, p. 431-458.

---1903, Certain river terraces of the Klamath region, California: American Journal of Science, v. 4, no. 16 , p. 240-250.

---1904, Bragdon formation in northwestern California: American Geologist,v. 33, p. 248-256, 347-360.

---1904, The river terraces of the Orleans Basin, California: California University, Department of Geological Sciences. Bulletin 3, p. 423-474.

---1906, Some western Klamath stratigraphy: American Journal of Science, series 4, v. 21, p. 58-66.

---1909, Black Diamond, Del Norte County, California: Mining and Scientific Press, v. 98, p. 147.

---1910, Origin of gold "pockets" in northern California: Mining and Scientific Press, v. 101, p. 741-742.

---1911, Del Norte County (California) geology: Mining and Scientific Press, v. 102, p. 468.

---1915, The geology of Iron Mountain (Shasta County, California): Mining and Scientific Press, v. 111, p. 633-638.

Hewett, D.F., Chesterman, C.W., and Troxel, B.W., 1961, Tephroite in California manganese deposits: Economic Geology, v. 56, no. 1, p. 39-58.

Heyl, G.R., and Walker, G.W., 1949, Geology of limestone near Gazelle, Siskiyou County, California: California Journal of Mines and Geology, v. 45, no. 4, p. 514-520.

Hicks, B.G., 1974, China slide, in Geologic guide to the southern Klamath Mountains: Geological Society of Sacramento, Annual Field Trip Guidebook, p. 58.

Hicks, B.G., and Collins, T.K., 1970, Role of engineering geology in forest road construction and logging practices to reduce impact on environment, in Engineering geology and man's environment: Association of Engineering Geologists, Annual Meeting, Program, p. 14.

---1971, Acceleration of mass movement by debris flow activity: Association of Engineering Geologists, Program, 14th National Meeting, Portland, Oregon, p. 25-26.

Hicks, D.L., 1964, Geology of the southwest quarter of the Roseburg quadrangle, Oregon: Eugene, University of Oregon, M. S. thesis, 65 p.

Hietanen, A., 1981, Extension of Sierra Nevada-Klamath suture system into eastern Oregon and western Idaho, in Petrologic and structural studies in the northwestern Sierra Nevada, California: U.S. Geological Survey Professional Paper 1226-C, p. C1-C11.

---1981, The Feather River Area as a part of the Sierra Nevada suture system in California, in Petrologic and structural studies in northwestern Sierra Nevada: U.S. Geological Survey Professional Paper 1226-B, 13 p.

Higinbotham, L., 1987, Montgomery Creek Formation, Klamath Mountains, Shasta County, California: California Geology, v. 40, no. 6, p. 130-138.

Hill, L.B., 1982, New tectonic boundaries in the north central Klamath Mountains between Happy Camp and Seiad Valley, California: Geological Society of America, Abstracts with Programs, v. 14 , no. 4, p. 172-173.

---1983, A preliminary model for crystalline overthrusts and associated deformation in the northern Klamath Mountains: Geological Society of America, Abstracts with Programs, v. 15, no. 5, p. 426.

---1984, Metamorphic and deformational constraints on terrane assembly, northern Klamath Mountains, California, in Howell, D.G., and others, eds., Proceedings of the circum-Pacific terrane conference, 1983: Stanford University Publications in the Geological Sciences, v. 18, p. 108-110.

---1984, A tectonic and metamorphic history of the north-central Klamath Mountains, California: Stanford, Calif., Stanford University, Ph.D. dissertation, 248 p. 
---1985, Metamorphic, deformational and temporal constraints on terrane assembly, northern Klamath Mountains, California, in Howell, D. G., ed., Tectonostratigraphic terranes of the circum-Pacific region: Circumpacific Council for Energy and Mineral Resources, Earth Science Series No. 1, p. 173186.

Hill, M., 1972, Hunting diamonds in California: Naturegraph Publications, Healdsburg, Calif., 80 p.

Hilton, R.P., 1975, The geology of the Ingot-Round Mountain area, Shasta County, California: Chico, California State University, M.A. thesis, 83 p.

Himmelberg, G.R., and Loney, R.A., 1973, Petrology of the Vulcan Peak Alpine-type peridotite, southwestern Oregon: Geological Society of America Bulletin, v. 84, no. 5, p. 1585-1600.

Hinds, N.E.A., 1929, Intrusive rocks in the Klamath Mountains, northern California: Geological Society of America Bulletin, v. 40, no. 1, p. 170.

---1930, Igneous geology of the southern Klamath Mountains, California: Geological Society of America Bulletin, v. 41, no. 1, p. 157-158.

---1931, Most ancient formations in Klamath Mountains: Geological Society of America Bulletin, v. 42, no. 1, p. 292-293.

---1932, Diastrophic epochs in the southern Klamath Mountains, California: Geological Society of America Bulletin, v. 43, no. 1, p. 273-274.

---1932, Paleozoic eruptive rocks of the southern Klamath Mountains, California: California University, Department of Geological Science Bulletin, v. 20, no. 11, p. 375-410.

---1933, Geologic formations of the Redding-Weaverville districts, northern California: California Journal of Mines and Geology, v. 29, no. 1, 2, p. 77-122.

---1934, The Jurassic age of the last granitoid intrusives in the Klamath Mountains and Sierra Nevada, California: American Journal of Science, 5th series, v. 27, no. 159, p. 182-192.

---1934, Geology of Weaverville district, northern California: Geological Society of America Proceedings, p. 315-316.

---1935, Late Cenozoic history of southern Klamath Mountains: Geological Society of America Proceedings 1934, p. 319.

---1935, Mesozoic and Cenozoic eruptive rocks of the southern Klamath Mountains, California: California University, Department of Geological Sciences Bulletin, v. 23, no. 11, p. 313-380.

---1940, Paleozoic section in the southern Klamath Mountains, California: Pacific Science Congress, 1939, Proceedings, 6th, v. 1, p. 273-287.

---1952, Evolution of the California landscape: California Division of Mines Bulletin 158, 240 p.

Hintze, L.F., 1956, Structural trends in Oregon: Geological Society of America Bulletin, v. 67, no. 12, pt. 2, p. 1771.

Hirt, W.H., ed., 1999, Across the Klamath/Cascade Frontier: National Association of Geoscience Teachers, Far Western Section, Fall Field Conference, Sept. 17-19, 87 p.

Hixson, H.C., 1965, Geology of the southwest quarter of the Dixonville quadrangle, Oregon: Eugene, University of Oregon, M.S. thesis, $97 \mathrm{p}$.

Hobson, J.B., 1890, Siskiyou County, in 10th Report of the State Mineralogist: California State Mining Bureau, p. 655-658.

Hodson, W.G., 1892, Shasta County in 11th Report of the State Mineralogist: California State Mining Bureau, p. 395-399.

Holdaway, M.J., 1963, Petrology and structure of metamorphic and igneous rocks of parts of northern Coffee Creek and Cecilville quadrangles, Klamath Mountains, California: Berkeley, California University, Ph.D. dissertation, 202 p.

---1963, Mafic metamorphic rocks in a portion of the Klamath Mountains, northern California: Geological Society of America Special Paper 73, p. 172-173.

---1965, Basic regional metamorphic rocks in part of the Klamath Mountains, northern California: American Mineralogist, v. 50, p. 953-977.

Hollister, V.F., 1949, Geology of the Shasta gold-silver district, Shasta County, California: Berkeley, University of California, M.S. thesis, $45 \mathrm{p}$.

Hollister, V.F., and Evans, J.R., 1965, Geology of the Redding quadrangle, Shasta County, California: California Division of Mines and Geology Map Sheet Series 4, scale 1:24,000.

Hood, J.W., 1883, Nickel ore from Piney Mountain, Douglas County, Oregon: Mineralogical Magazine 5, p. 193.

Hopson, C.A., and Mattinson, J.M., 1973, Ordovician and Late Jurassic ophiolitic assemblages in the Pacific northwest: Geological Society of America, Cordilleran Section, 69th Annual Meeting, 
Program, Portland, Oregon, v. 5, no. 1, p. 57.

Horton, R., and Smith, B.D., 1985, Electrical geophysical studies of massive sulfide deposits and their host rocks, West Shasta copper-zinc district, in Krafft, K., ed., U.S.G.S. research on mineral resources, 1985; program and abstracts: U.S. Geological Survey, Circular 0949, p. 26-27.

Horton, R.J., Smith, B.D., and Washburne, J.C., 1985, Electrical geophysical investigations of massive sulfide deposits and their host rocks, West Shasta copper-zinc district: Economic Geology, v. 80, no. 8 , p. 2213-2229.

Hotz, P.E., 1940, Paleozoic volcanic rocks in the Medford quadrangle, Oregon: Berkeley, University of California, M. S. thesis, $40 \mathrm{p}$.

---1964, Nickeliferous laterites in southwestern Oregon and northwestern California: Economic Geology, v. 59, no. 3, p. 355-396.

---1966, Nickel, in Mineral resources of California: U.S. 89th Congress, 2nd Session, Senate Committee of the Interior and Insular Affairs, Committee Printing, p. 279-284; also in California Division of Mines and Geology Bulletin 191.

---1967, Geologic map of the Condrey Mountain quadrangle and parts of the Seiad Valley and Hornbrook quadrangles, California: U.S. Geological Survey Geological Quadrangle Map GQ-618, scale $1: 62,500$.

---1969, Relations between the Dothan and Rogue Formations, southwest Oregon: Geological Society of America, Cordilleran Section, 65th Annual Meeting, Program, Eugene, Oregon, pt. 3, p. 27-28.

---1969, Relationships between the Dothan and Rogue Formations, southwestern Oregon, in Geological Survey research 1969, chapter D: U.S. Geological Survey Professional Paper 650-D, p. D131-D137.

---1971, Plutonic rocks of the Klamath Mountains, California and Oregon: U.S. Geological Survey Professional Paper 684-B, 20 p.

---197l, Geology of the lode gold districts in the Klamath Mountains, California and Oregon: U.S. Geological Survey Bulletin 1290, $91 \mathrm{p}$.

---1973, Blueschist metamorphism in the Yreka-Fort Jones area, Klamath Mountains, California: U.S. Geological Survey Journal of Research, v. 1, no. 1, p. 53-61; also in Geologic guide to the southern Klamath Mountains: Geological Society of Sacramento, Annual Field Trip Guidebook, p. 101-109.

---1973, Blueschist metamorphism in the Yreka-Port Jones area, northeastern Klamath Mountains, California: Geological Society of America, Abstracts with Programs, v. 5, no. 1, p. 59-60.

---1974, Preliminary geologic map of the Yreka quadrangle, California: U.S. Geological Survey Miscellaneous Field Studies Map MF-568.

---1977, Blueschist facies rocks in the Yreka-Fort Jones area, Klamath Mountains, California, in Guidebook to the geology of the Klamath Mountains, northern California: Geological Society of America, Cordilleran Section, 73rd Annual Meeting, Sacramento, California, Guidebook, p. 26-33.

---1977, Paleozoic rocks in the Yreka area, Klamath Mountains, California: Geological Society of America, Abstracts with Programs, v. 9, no. 4, p. 438.

---1977, Geology of the Yreka quadrangle, Siskiyou County, California: U.S. Geological Survey Bulletin 1436, 72 p.

---1978, Geologic map of the Yreka quadrangle and parts of the Fort Jones, Etna, and China Mountain quadrangles, California: U.S. Geological Survey Open-file Report 78-12, scale 1:62,500.

---1979, Regional metamorphism in the Condrey Mountain quadrangle, north-central Klamath Mountains, California: U.S. Geological Survey Professional Paper 1086, 25 p.

Hotz, P.E., Greene, R.C., Close, T.J., and Evans, R.K., 1974, Mineral resources of proposed additions to the Salmon-Trinity Alps Primitive Area, California (A supplement to U. S. Geological Survey Bulletin 1371-B): U.S. Geological Survey Open-file Report, 70 p.

---1982, Mineral resources of proposed additions to the Salmon-Trinity Alps Primitive area, California: U. S. Geological Survey Bulletin 1514, 54 p.

Hotz, P.E., Lanphere, M.A., and Swanson, D.A., 1977, Triassic blueschist from northern California and north-central Oregon: Geology, v. 5, no. 11, p. 659-663.

Hotz, P.E., and Thurber, H.K., 1984, Salmon-Trinity Wilderness, California, in S. P. Marsh and others, eds., Wilderness Mineral Potential: U.S. Geological Survey Professional Paper 1300, v. 1, p. 340-342.

Hotz, P.E., Thurber, H.K., Marks, L.Y., and Evans, R.K., 1972, Mineral resources of the Salmon-Trinity Alps primitive area, California: U.S. Geological Survey Bulletin 1371-B, 267 p.

Howe, S.S., 1985, Mineralogy, textures, and relative age relationships of massive sulfide ore in the West Shasta district, California: Economic Geology, v. 80, no. 8, p. 2114-2127. 
Huber, D.F., and Cather, E.E., 1984, Fisher Gulch Roadless Area, California, in S.P. Marsh and others, eds., Wilderness Mineral Potential: U.S. Geological Survey Professional Paper 1300, v. 1, p. 245-247.

---1984, Lake Eleanor Roadless Area, California, in S. P. Marsh and others, eds., Wilderness Mineral Potential: U.S. Geological Survey Professional Paper 1300, v. 1, p. 278-279.

Huber, D.F., and Nelson, S.C., 1983, Mineral resource potential of the Granite Peak Roadless Area, Trinity County, California: U. S. Geological Survey, Open-File Report 83-0489, 10. p.

Huber, D.F., Nelson, S.C., Cather, E.E., and Ritchey, J.L., 1983, Mineral resource potential of the Fisher Gulch Roadless Area, Trinity County, California: U.S. Geological Survey, Open-File Report 83-0483, $11 \mathrm{p}$.

Huber, D.F., Nelson, S.C., Fraticelli, L.A., and Stebbins, S.A., 1983, Mineral resounce potential map of the Chanchelulla Roadless Area, Trinity County, California: U.S. Geological Survey, Open-File Report 83-0506, $14 \mathrm{p}$.

Huber, D.F., and Stebbins, S.A., 1984, Chanchelulla Peak Roadless Area, California, in S.P. Marsh and others, eds., Wilderness Mineral Potential: U.S. Geological Survey Professional Paper 1300, v. 1, p. 205-207.

Huber, D.F., and Thurber, H.K., 1984, Granite Peak Roadless Area, California, in S.P. Marsh and others, eds., Wilderness Mineral Potential: U.S. Geological Survey Professional Paper 1300, v. 1, p. 258-259.

Hundhausen, R.J., 1947, Blue Ledge copper-zinc mine, Siskiyou County, California: U.S. Bureau Mines Report of Investigations 4124, $16 \mathrm{p}$.

---1952, Investigation of Shamrock copper-nickel mine, Jackson County, Oregon: U. S. Bureau of Mines Report of Investigations 4895, $12 \mathrm{p}$.

Hutchinson, R.W., 1973, Volcanogenic sulfide deposits and their metallogenic significance: Economic Geology, v. 68, no. 8, p. 1223-1246.

Hutchinson, R.W., and Albers, J.P., 1992, Metallogenic evolution of the Cordilleran region of the western United States, in Burchfiel, B.C., Lipman, P.W., and Zoback, M.L., eds., The Geology of North America Volume G-3, The Cordilleran Orogen: Conterminous U.S.:

Hyatt, A., and Smith, J.P., 1905, The Triassic cephalopod genera of America: U.S. Geological Survey Professional Paper 40, 394 p.

Imlay, R.W., Dole, H.M., Wells, F.G., and Peck, D.L., 1959, Relations of certain Jurassic and Lower Cretaceous formations in southwestern Oregon: American Association of Petroleum Geologists Bulletin, v. 43, no. 12, p. $2770-2785$.

Ingersoll, R.V., and Schweickert, R.A., 1983, The Nevadan Orogeny in northern California: Contrasts in Klamath Mountains and Sierra Nevada, and origin of the Coast Range Ophiolite: Eos (American Geophysical Union Trans.), v. 64, no. 45, p. 833.

---1986, A plate tectonic model for Late Jurassic ophiolite genesis, Nevadan orogeny and forearc initiation, northern California: Tectonics, v. 5, no. 6, p. 901-912.

Irelan, W., Jr., 1888, Humboldt County [p. 216-223], Shasta County [p. 562-572], Siskiyou County [p. 581631], and Trinity County [p. 637-643] in 8th Annual Report of the State Mineralogist: California State Mining Bureau.

Irwin, W.P., 1960, Geologic description along U.S. Highway 299, between Weaverville and Arcata, California: Geological Society of Sacramento, Annual Field Trip, June 1960, Guidebook, p. 22-31.

---1960, Geologic reconnaissance of the northern Coast Ranges and Klamath Mountains, California, with a summary of the mineral resources: California Division of Mines Bulletin 179, $80 \mathrm{p}$.

---1960, Relations between Abrams mica schist and Salmon hornblende schist in Weaverville quadrangle, California, in Geological Survey research, 1960: U.S. Geological Survey Professional Paper 400-B, p. B315-B316.

---1963, Preliminary geologic map of the Weaverville quadrangle, California: U.S. Geological Survey Mineral Investigations Field Studies Map MF-275, scale 1:62,500.

---1964, Late Mesozoic orogenies in the ultramafic belts of northwestern California and southwestern Oregon, in Geological Survey research, 1964: U.S. Geological Survey Professional Paper 501-C, p. C1-C9.

---1966, Geology of the Klamath Mountains, in Mineral and water resources of California: U.S. 89th Congress, 2nd Session, Senate Committee of the Interior and Insular Affairs, Committee Printing, p. 40-43; also in California Division of Mines and Geology Bulletin 191. 
---1966, Geology of the Klamath Mountains province, in Geology of northern California: California Division of Mines and Geology Bulletin 190, p. 19-38; also in Geologic guide to the southern Klamath Mountains: Geological Society of Sacramento, Annual Field Trip Guidebook, p. 17-56.

---1972, Terranes of the western Paleozoic and Triassic belt in the southern Klamath Mountains, California, in Geological Survey research, 1972: U.S. Geological Survey Professional Paper 800-C, p. C103-C111; also in Geologic guide to the southern Klamath Mountains: Geological Society of Sacramento, Annual Field Trip Guidebook, p. 37-45.

---1973, Sequential minimum ages of oceanic crust in accreted tectonic plates of northern California and southern Oregon: Geological Society of America, Cordilleran section, 69th Annual Meeting, Program, Portland, Oregon, v. 5, no. 1, p. 62-63.

---1974, Reconnaissance geologic map of the Hayfork quadrangle, Trinity County, California: U.S. Geological Survey, Miscellaneous Field Studies Map MF-576, scale 1:62,500.

---1975, Pacific Northwest Region, in Paleotectonic investigations of the Pennsylvanian System in the United States: U.S. Geological Survey Professional Paper 853, Pt. 1, p. 329-332.

---1977, Ophiolitic terranes of California, Oregon, and Nevada, in Coleman, R. G., and Irwin, W. P., eds., North American ophiolites: Oregon Department of Geology and Mineral Industries, Bulletin 95, p. 75-92.

---1977, Review of Paleozoic rocks of the Klamath Mountains, in Paleozoic paleogeography of the western United States: Society of Economic Paleontologists and Mineralogists, Pacific Coast Paleogeography Symposium 1, p. 441-454.

---1979, Ophiolitic terranes of part of the western United States, in International atlas of ophiolites: Geological Society of America Map and Chart Series MC-33, International Geological Correlation Program, Project 39 "Ophiolites of continents and comparable oceanic rocks," sheet 1, with text.

---1980, The Klamath Mountains, in Aubouin, J., Blanchet, R., and Rangin, C., eds., Reunion extraordinaire de la Societe Geologique de France en California, 4 septembre-13 1979: Bulletin de la Societe geologique de France, v. 22, no. 4, p. 527-532.

---1981, Tectonic accretion of the Klamath Mountains, in Ernst, W.G., ed., The geotectonic development of California; Rubey Volume I: Prentice-Hall, Inc., Englewood Cliffs, New Jersey, p. 29-49.

---1984, Preaccretion and postaccretion plutonic belts in allochthonous terranes of the Klamath Mountains, California and Oregon, in Howell, D.G., and others, eds., Proceedings of the circum-Pacific terrane conference, 1983: Stanford University Publications in the Geological Sciences, v. 18, p. 119-121.

---1984, Plutonic belts in allochthonous terranes of the Klamath Mountains, California and Oregon: Geological Society of America, Abstracts with Programs, v. 16, no. 5, p. 290.

---1985, Age and tectonics of plutonic belts in accreted terranes of the Klamath Mountains, California and Oregon in D.G. Howell, ed., Tectonostratigraphic terranes of the circum-Pacific region: Circum-Pacific Council for Energy and Mineral Resources, Earth Science Series, Number 1, p. 187199.

---1985, Reconnaissance geologic map of the Hyampom quadrangle, Trinity County, California; U.S. Geological Survey Miscellaneous Field Studies Map MF-1809, scale 1:62,500.

---1989, Terranes of the Klamath Mountains, California and Oregon, in Tectonic evolution of northern California: 28th International Geological Congress, Field Trip Guidebook T108, Sausalito to Yosemite National Park, California, June 28-July 7, 1989, p. 19-32

---1989, Cryptic tectonic domains of the Klamath Mountains, California and Oregon, in A.M. Johnson, C.W. Burnham, C.R. Allen, and W. Muehlberger, eds., Richard H. Jahns Memorial Volume: Engineering Geology, v. 27, nos. 1-4, p. 433-448.

---1994, Geologic Map of the Klamath Mountains, California and Oregon: U.S. Geological Survey, Miscellaneous Investigations Map I-2148, 2 sheets, scale 1:500,000.

---1995, A bibliography of Klamath Mountains geology, listing authors from Aalto to Zucca for the years 1849 to mid-1995: U.S. Geological Survey Open-File Report 95-558, 151 p.

---1997, Preliminary map of selected post-Nevadan geologic features of the Klamath Mountains and adjacent areas, California and Oregon: U.S. Geological Survey, Open-File Report 97-465, 29 p. text, map scale 1:500,000.

---1997, Field guide for a GEOMAR and University of Kiel trip across the accreted terranes of the southern Klamath Mountains, California, June 14, 1997: U.S. Geological Survey, Open-File Report 97-288, 23 p., 1 map.

---1999, Relation of plutons to accretionary episodes of the Klamath Mountains, California and Oregon: 
Geological Society of America, Abstracts with Programs, v. 31, no. 6, p. 65.

---2002, Correlation of the Klamath Mountains and Sierra Nevada; Geological Society of America, Abstracts with Programs, v. 34, no. 5, p. A-5.

---2003, Correlation of the Klamath Mountains and Sierra Nevada: Sheet 1--Map showing accreted terranes and plutons of the Klamath Mountains and Sierra Nevada, scale 1:1,000,000: Sheet 2-Successive accretionary episodes of the Klamath Mountains and northern part of the Sierra Nevada: U.S. Geological Survey, Open-File Report 02-490, 2 sheets.

Irwin, W.P., and Bath, G.D., 1962, Magnetic anomalies and ultramafic rock in northern California, in Geological Survey research, 1962: U.S. Geological Survey Professional Paper 450-B, article 25, p. B65-B67.

Irwin, W.P., Blome, C.D., and Jones, D.L., 1982, Age and tectonic implication of radiolarian chert in the North Fork terrane, Klamath Mountains, California: Geological Society of America, Abstracts with Programs, v. 14, no. 4, p. 174.

Irwin, W.P., and Dennis, M.D., 1979, Geologic structure section across southern Klamath Mountains, Coast Ranges, and seaward of Point Delgada, California: Geological Society of America, Map and Chart Series, MC-28D, scale 1:250,000.

Irwin, W.P., and Galanis, S.P., Jr., 1976, Map showing limestone and selected fossil localities in the Klamath Mountains, California and Oregon: U.S. Geological Survey, Miscellaneous Field Studies Map MF-749, scale 1:500,000.

Irwin, W.P., and Hotz, P.E., 1974, Geologic sketch of the Klamath Mountains and Coast Ranges of northern California and southern Oregon, in Geologic guide to the southern Klamath Mountains: Geological Society of Sacramento, Annual Field Trip Guidebook, p. 46-53.

---1979, Geology of the Douglas-fir region; The Klamath Mountains and Coast Ranges of northern California, in Heilman, P. E., Anderson, H. W., and Baumgartner, D. M., eds., Forest soils of the Douglas-fir region: Pullman, Washington State University, Department of Forest Range Management, p. 7-10.

Irwin, W.P., Jones, D.L., and Blome, C.D., 1982, Map showing sampled radiolarian localities in the western Paleozoic and Triassic belt, Klamath Mountains, California: U.S. Geological Survey Miscellaneous Field Studies Map MF-1399, scale 1:250,000.

Irwin, W.P., Jones, D.L., and Kaplan, T.A., 1978, Radiolarians from pre-Nevadan rocks of the Klamath Mountains, California and Oregon, in Howell, D.G., and McDougall, K,A., eds.,Mesozoic paleogeography of the western United States: Society of Economic Paleontologists and Mineralogists, Pacific Section, Pacific Coast Paleogeography Symposium 2, p. 303-310.

Irwin, W.P., Jones, D.L., and Pessagno, E.A., Jr., 1977, Significance of Mesozoic radiolarians from the pre-Nevadan rocks of the southern Klamath Mountains, California: Geological Society of America, Geology, v. 5, p. 557-562.

Irwin, W.P., and Lipman, P.W., 1962, A regional ultramafic sheet in eastern Klamath Mountains, California, in Geological Survey research, 1962: U.S. Geological Survey Professional Paper 450-C, p. C18-C21.

Irwin, W.P., and Mankinen, E.A., 1998, Rotational and accretionary evolution of the Klamath Mountains, California and Oregon, from Devonian to present time: U.S. Geological Survey, OpenFile Report 98-114, 1 map sheet.

Irwin, W.P., Mankinen, E.A., and Gromme, C.S., 1984, Paleomagnetism in the Klamath Mountains, California and Oregon, in Howell, D. G., and others, eds., Proceedings of the circum-Pacific terrane conference, 1983: Stanford University Publications in the Geological Sciences, v. 18, p. 122-125.

Irwin, W.P., and Tatlock, D.B., 1955, Reconnaissance of northwestern California--a progress report: Geological Society of America Bulletin, v. 66, no. 12, pt. 2, p. 1653-1654.

Irwin, W.P., Tatlock, D.B., Weibelt, F., Shea, G.B., and Maurer, R.B., 1955, Geology, mineral resources, and mineral industry, Appendix to Natural resources of northwestern California: U.S. Department of the Interior, Pacific Southwest Field Commission, $40 \mathrm{p}$.

Irwin, W.P., Wardlaw, B.R., and Kaplan, T.A., 1983, Conodonts of the western Paleozoic and Triassic belt, Klamath Mountains, California and Oregon: Journal of Paleontology, v. 57, no. 5, p. 1030-1039.

Irwin, W.P., and Wooden, J.L., 1999, Plutons and accretionary episodes of the Klamath Mountains, California and Oregon: U.S. Geological Survey, Open-File Report 99-374, 1 sheet.

Irwin, W.P., Wolfe, E.W., Blake, M.C., Jr., and Cunningham, C.G., Jr., 1974, Geologic map of the Pickett 
Peak quadrangle, Trinity County, California: U.S. Geological Survey Geological Quadrangle Map GQ-1111, scale 1:62,500.

Irwin, W.P., Yule, J.D., Court, B.L., Snoke, A.W., Stern, L.A., and Copeland, W.B., 1985, Reconnaissance geologic map of the Dubakella Mountain quadrangle, Trinity, Shasta, and Tehama Counties, California: U.S. Geological Survey Miscellaneous Field Studies Map MF-1808, scale 1:62,500.

Ishiwatari, A. Malpas, J., and Ishizuka, H., eds., 1994, Ophiolites of the Circum-Pacific Region, Proceedings 29th International Geological Congress, Part D: VSP International Science Publishers, the Netherlands, p. 47-68.

Isozaki, Yukio, and Maruyama, S., 1992, Subhorizontal sandwich structure of cordilleran blueschist: A new criterion to understand the Klamath-Franciscan geology: Geological Society of America, Abstracts with Programs, v. 24, no. 5, p.35.

Jachens, R.C., and Elder, W.P., 1983, Aeromagnetic map and interpretation of geophysical data from the Condrey Mountain Roadless Area, Siskiyou County, California: U.S. Geological Survey Miscellaneous Field Studies Map MF-1540-B, scale 1:50,000.

Jachens, R.C., and Griscom, A., 1983, Three-dimensional geometry of the Gorda Plate beneath northern California: Journal of Geophysical Research, v. 88, no. B11, p. 9375-9392.

Jachens, R.C., Barnes, C.G., and Donato, M.M., 1986, Subsurface configuration of the Orleans fault: implications for deformation of the western Klamath Mountains, California: Geological Society of America Bulletin, v. 97, no. 4, p. 388-395.

Jacobsen, S.B., Quick, J.E., and Wasserburg, G.J., 1984, A Nd and Sr isotopic study of the Trinity Peridotite; implications for mantle evolution: Earth and Planetary Science Letters, v. 68, no. 3, p. 361-378.

Jameossanaie, A., and Lindsley-Griffin, N., 1993, Palynology and plate tectonics - A case study on Cretaceous terrestrial sediments in the Eastern Klamath Mountains of northern California, U.S.A.: Palynology, v. 17, p. 11-45.

Jameossanaie, A., Lindsley-Griffin, N., and Griffin, J.R., 1986, Significance of palynological studies in revealing earliest post-accretion age of the Hornbrook successor basin, northern California: American Association of Stratigraphic Palynologists, Abstracts, Annual Meeting 1985, Palynology, v. 10. p. 250.

Jayko, A.S., 1990, Stratigraphy and tectonics of Paleozoic arc-related rocks of the northernmost Sierra Nevada, California; The eastern Klamath and northern Sierra terranes, in Harwood, D.S., and Miller, M.M., eds., Paleozoic and early Mesozoic paleogeographic relations; Sierra Nevada, Klamath Mountains, and related terranes; Geological Society of America Special Paper 255, p. 307-323.

Jayko, A.S., and Blake, M.C., Jr., 1984, Geologic map of part of the Orleans Mountain Roadless Area, Siskiyou and Trinity Counties, California: U.S. Geological Survey, Miscellaneous Field Studies Map MF-1600-A, scale 1:48,000.

Jayko, A.S., Blake, M.C., Jr., Marks, L.Y., Thurber, H.K., and Evans, R.J., 1983, Mineral resource potential map of parts of the Orleans Mountain Roadless Area, Siskiyou and Trinity Counties, California: U. S. Geological Survey, Miscellaneous Field Studies Map MF-1600-B, scale 1:48,000, with text, $9 \mathrm{p}$.

Jayko, A.S., and Marks, L.Y., 1984, Orleans Mountain Roadless Area (C5079, B5079), California, in Wilderness Mineral Potential, S. P. Marsh and others, eds.: U.S. Geological Survey Professional Paper 1300, v. 1, p. 323-325.

Jenkins, O.P., 1938, Geologic map of California: California Division of Mines, scale 1 in. $=8 \mathrm{mi}$.

---1943, Geomorphic provinces of California: California Division of Mines Bulletin 118, p. 83-88.

Jenkins, O.P., and others, 1943, Manganese in California: California Division of Mines Bulletin 125, 387 p.

---1948, Copper in California: California Division of Mines Bulletin 144, 429 p.

Jennings, C.W., 1977, Geologic map of California: California Division of Mines and Geology, Geologic Map Data Series, Map no. 2, scale 1:750,000.

Jennings, C.W., and Saucedo, G.J., 1994, Fault activity map of California and adjacent areas, with locations and ages of recent volcanic eruptions: California Division of Mines and Geology, Geologic Map Data Series, Map no. 6, scale 1:750,000.

Johnson, J.H., and Konishi,K., 1959, Some Silurian calcareous algae from northern California and Japan, pt. 3 of Johnson, J.H., Konishi, K., and Rezak, R., Studies of Silurian (Gotlandian) Algae:

Colorado School Mines Quarterly, v. 54, no. 1, p. 131-158. 
Johnson, K., and Barnes, C.G., 1991, Magma mixing and mingling in late-stage felsic dikes of the Grayback pluton, Klamath Mountains, SW Oregon: Geological Society of America, Abstracts with Programs, v. 23, no. 2, p. 39.

Johnson, M.G., 1977, Mesozoic metavolcanic sequences in the northern Klamath Mountains, southwestern Oregon: Geological Society of America, Abstracts with Programs, v. 9, no. 4, p.442.

---1980, Geochemical variations within an ancient island arc, southwestern Oregon: Geological Society of America, Abstracts with Programs, v. 12, no. 3, p. 113.

Johnson, M.G., and Page, N.J., 1979, Preliminary geologic map of the metavolcanic and associated rocks in parts of the Canyonville, Days Creek, and Glendale quadrangles, Oregon: U. S. Geological Survey Open-File Report 79-283, scale 1:62,500.

Johnston, W.D., Jr., 1935, Copper in Trinity County, in Copper resources of the world: International Geological Congress, 16th, Washington, p. 251.

---1936, Nodular, orbicular, and banded chromite in northern California: Economic Geology, v. 31, no. 4, p. $417-427$.

Johnson, W.R., 1965, Structure and stratigraphy of the southeastern quarter of the Roseburg 15' quadrangle, Douglas County, Oregon: Eugene, University of Oregon, M.S. thesis, 85 p.

Jones, D.L., 1959, Stratigraphy of Upper Cretaceous rocks in the Yreka-Hornbrook area, northern California: Geological Society of America Bulletin, v. 70, no. 12, pt. 2, p. 1726-1727.

---1960, Lower Cretaceous (Albian) fossils from southwestern Oregon and their paleogeographic significance: Journal of Paleontology, v. 34, no. 1, p. 152-160.

---1972, Structural significance of Upper Mesozoic biostratigraphic units in northern California and southwestern Oregon: Geological Society of America, Abstracts with Programs, v. 5, no. 7, p. 684-685.

Jones, D.L., and Imlay, R.W., 1973, Structure of Upper Jurassic and Lower Cretaceous rocks in the Riddle area, southwestern Oregon: Geological Society of America, Abstracts with Programs, v. 5, no. 1, p. 64.

Jones, D.L., and Irwin, W.P., 1971, Large-scale displacement of an Early Cretaceous shoreline in northern California: Geological Society of America, Abstracts with Programs, v. 3, no. 2, p. 141-142.

---1971, Structural implications of an offset Early Cretaceous shoreline in northern California: Geological Society of America Bulletin, v. 82, no. 4, p. 815-822.

Jones, F.R., and Harper, G.D., 1988, Late Nevadan thrusting in the western Klamath Mountains: Structural evidence from the northern Galice Formation: Geological Society of America, Abstracts with Programs, v. 20, no, 3, p. 172.

Jones, F.R., 1988, Structural geology of the northern Galice Formation, western Klamath Mountains, Oregon and California: Albany, State University of New York, M.Sc. thesis, 211 p.

Jones, F.R., and Harper, G.D., 1988, Late Nevadan thrusting in the western Klamath Mountains: Evidence from the northern Galice Formation: Geological Society of America, Abstracts with Programs, v. 20, no. 3, p. 172.

Jordan, D.S., 1907, The fossil fishes of California: California University, Department, Geological Science Bulletin, v. 5, p. 95-144.

Jorgenson, D.B., 1970, Petrology and origin of the Illinois River gabbro, a part of the Josephine Peridotite-Gabbro complex, Klamath Mountains, southwestern Oregon: Santa Barbara, California University, Ph.D. dissertation, 226 p.

---1971, Origin of patchy zoning in plagioclase from gabbroic rocks of southwestern Oregon: Geological Society of America Bulletin, v. 82, no. 9, p. 2667-2670.

---1979, Textural banding in igneous rocks; an example from southwestern Oregon: American Mineralologist v. 64, no. 5-6, p. 527-530.

Kay, G.F., 1907, Nickel deposits of Nickel Mountain, Oregon: U.S. Geological Survey Bulletin 315, p. $120-127$.

---1908, Gold-quartz mines of the Riddles quadrangle, Oregon: U.S. Geological Survey Bulletin 340, p. 134-147.

---1908, Notes on copper prospects of the Riddles quadrangle, Oregon: U.S. Geological Survey Bulletin 340, p. 152.

Kays, M.A., 1968, Zones of alpine tectonism and metamorphism, Klamath Mountains, southwestern Oregon: Journal of Geology, v. 76, no. 1, p. 17-36.

---1970, Mesozoic metamorphism, May Creek Schist belt, Klamath Mountains, Oregon: Geological 
Society of America Bulletin, v. 81, no. 9, p. 2743-2758.

---1973, Metamorphism-plutonism in the western Paleozoic and Triassic belt of the northern Klamath Mountains, Oregon and California: Geological Societyof America, Abstracts with Programs,v. 5, no. 1, p. 65.

---1987, Metamorphism of TRPZ oceanic rocks, Blue Mountains and Klamath Mountains, Oregon and

California: Geological Society of America Abstracts with Programs, v. 19, no. 6, p. 393.

---1992, Model for metamorphism, northern Klamath Mountains, Oregon: Geological Society of America, Abstracts with Programs, v. 24, no. 5, p. 37.

---1992, Geologic guide for the northern Klamath Mountains: Part 1, Cow Creek to Red Mountain: Oregon Geology, v. 54, no. 2, p. 27-33.

---1995, Metamorphism in the northern Klamath Mountains, Oregon, in Miller, D. M., and Busby, C., eds, Jurassic Magmatism and Tectonics of the North American Cordillera: Geological Society of America, Special Paper 299, p. 173-190.

Kays, M.A., and Bruemmer, J.L., 1963, Gravity and petrographic investigation along zones of local metamorphism, SW Oregon: Northwest Science, v. 37, no. 4, p. 159-160.

---1964, Gravity field over zones of major tectonism, southwest Oregon: Ore Bin, v. 26, no. 3, p. 43-52.

---1965, Gravity and petrographic investigations along zones of local metamorphism, southwest Oregon: Geological Society of America, Special Paper 82, p. 258-259.

Kays, M.A., and Ferns, M.L., 1980, Geologic field trip guide through the north-central Klamath Mountains: Oregon Geology, v. 42, no. 2, p. 23-35.

Kays, M.A., Ferns, M., and Beskow, L., 1977, Complementary meta-gabbros and peridotites in the northern Klamath Mountains, U.S.A., in Magma genesis 1977; proceedings of the American Geophysical Union Chapman conference on partial melting in the Earth's upper mantle, Dick, H. J. B., ed.: Oregon Department of Geology and Mineral Industries Bulletin 96, p. 91-107.

Kays, M.A., Ferns, M.L., and Brooks, H.C., 1988, Metamorphism of Triassic-Paleozoic belt rocks: a guide to field and petrologic relations in the oceanic melange, Klamath and Blue Mountains, California and Oregon, in Ernst, W.G., ed., Metamorphism and Crustal Evolution of the Western United States, Rubey volume 7: Prentice Hall, Englewood Cliffs, N.J., p. 1098-1142.

Kays, M.A., and Helming, B.H., 1966, Anomalous metamorphism of Jurassic rocks, Klamath Mountains, southwestern Oregon: Geological Society of America Special Paper 87, p. 86-87.

Kays, M.A., Medaris, L.G., Jr., and Godchaux, M.M., 1972, Character and genesis of gneissic amphibolites, Klamath Mountains, Oregon and California: Geological Society of America, Abstracts with Programs, v. 4, no. 3, p. 181.

Kays, M.A., and Rice, J.M., 1991, Prograde Nevadan metamorphism in the northern Klamath Mountains, Oregon: Geological Society of America, Abstracts with Programs, v. 25, no. 45, p. 248.

Kelley, F.R., Wagner, D.L., and Saucedo, G.J., 1987, Radiometric ages of rocks in the Weed Quadrangle, California, in Wagner, D.L., and Saucedo, G.J., compilers, Geologic map of the Weed quadrangle: California Division of Mines and Geology, Regional Geologic Map Series, Map No. 4A, scale 1:250,000, text and table $15 \mathrm{p}$.

Kellogg, A.E., 1919, Cinnabar ore in Jackson County, Oregon: Engineering and Mining Journal, v. 107, p. 787.

---1919, Placer mining in Oregon: Engineering and Mining Journal, v. 108, p. 90-91.

---1921, Cobalt in Jackson County, Oregon: Engineering and Mining Journal, v. 112, no. 17, p. 650.

---1922, Platinum in the quartz veins of southwest Oregon: Engineering and Mining Journal, v. 113, no. 23, p. 1000.

---1927, Origin of manganese in southwestern Oregon: Mining Journal, Phoenix, Arizona, v. 11, no. 13, p. $7,13$.

---1927, Quicksilver in the Gold Hill, Oregon, District: Mining Journal, Phoenix, Arizona, v. 11, no. 8, p. 7, 14-15.

---1928, Auriferous gravels of southwest Oregon: Mining Journal, Phoenix, Arizona, v. 11, no. 20, p. 3-6, 54-55.

---1928, Llano de Oro placers, Waldo district, Oregon: Mining Journal, Phoenix, Arizona, v. 12, no. 4, p. 9-11.

---1928, Origin of copper in southwestern Oregon: Mining Journal, Phoenix, Arizona, v. 12, no. 2, p. 9-10.

---1929, Platinum in southwestern Oregon: Mining Journal, Phoenix, Arizona, v. 12, no. 23, p. 5-6.

Kemp, W.R., and Garcia, M., 1976, The Klamath Mountains and Sierra Nevada Jurassic volcanic arc sequences, western U.S.A.; volcanogenic sulfide provinces: International Geological Congress, 
Resumes 25, v. 1: Section 4, Mineral deposits; 4A, Genesis stratiform ore deposits, p. 168-169.

Kennedy, G.L., Diggles, M.F., amd Gaps, R.S., 1985, Mineral resource potential map of the Tunnel Ridge Wilderness Study Area, Klamath Mountains, California: U.S. Geological Survey, Miscellaneous Field Studies Map MF-1810-A, scale 1:24,000 with 7 page phamphlet.

Ketner, K.B., 1959, West Coast region, in Paleotectonic maps of the Triassic system: U.S. Geological Survey, Miscellaneous Geological Investigations Map I-300, p. 4-5, 11-12, 17-18, 19.

---1967, West Coast region, Chapter K, in Paleotectonics investigations of the Permian System in the United States: U.S. Geological Survey Professional Paper 515, p. 225-238.

Kett, W.F., 1947, Fifty years of operation by the Mountain Copper Company, Ltd., in Shasta County California: California Journal of Mines and Geology, v. 43, p. 105-162.

Kim, C.K., 1974, A gravity investigation of the Weed Sheet, northwestern California: Eugene, University of Oregon, Ph.D. dissertation, 168 p.: also Dissertation Abstracts, v. 35, no. 8, p. 3985B-3989B, 1975.

Kim, C.K., and Blank, H.R., Jr., 1973, Bouguer gravity map of California--Weed Sheet: California Division of Mines and Geology, scale 1:250,000.

Kimball, K.L., 1988, High-temperature hydrothermal alteration of ultramafic cumulates from the base of the sheeted dikes in the Josephine ophiolite, NW California: Journal of Geophysical Research, v. 93 , no. 5 , p. $4675-4687$.

Kimmel, B.L., II, 1977, Nutrient transfers associated with seston sedimentation and sediment formation in Castle Lake, California: Davis, University of California, Ph.D. dissertation.

Kingston, J.D., 1985, Geology of the northern Lamoine quadrangle, Shasta County, California: Berkeley, University of California, M.S. thesis, $146 \mathrm{p}$.

Kinkel, A.R., Jr., 1955, Structural and stratigraphic control of ore deposition in the West Shasta copper-zinc district, California: Mining Engineering, v. 7, no. 2, p. 167-174; A.I.M.E. Transaction 1955 , v. 202, 1956; discussion by R.T. Walker and W.J. Walker, and reply by author, Mining Engineering, v. 8, no. 3, p. 3-2-324, 1956; A.I.M.E. Transaction 1956, v. $205,1957$.

Kinkel, A.R., Jr., and Albers, J.P., 1949, The geology of the massive sulfide deposits at Iron Mountain, Shasta County, California: Economic Geology, v. 44, no. 1, p. 81-82.

---1951, Geology of the massive sulfide deposits at Iron Mountain, Shasta County, California: California Division of Mines Special Report 14, 19 p.

Kinkel, A.R., Jr., and Hall, W.E., 1951, Geology of the Shasta King mine, Shasta County, California: California Division of Mines Special Report 16, 11 p.

---1952, Geology of the Mammoth mine, Shasta County, California: California Division of Mines Special Report 28, $15 \mathrm{p}$.

Kinkel, A.R., Jr., Hall, W.E., and Albers, J.P., 1954, Geologic maps of the Shasta copper-zinc district, Shasta County, California: U.S. Geological Survey, Open-File Report 251.

---1956, Geology and base-metal deposits of West Shasta copper-zinc district, Shasta County, California: U.S. Geological Survey Professional Paper 285, 156 p.

Kistler, R.W., McKee, E.H., Futa, K., Peterman, Z.E., and Zartman, R.E., 1985, A reconnaissance Rb-Sr, $\mathrm{Sm}-\mathrm{Nd}, \mathrm{U}-\mathrm{Pb}$, and K-Ar study of some host rocks and ore minerals in the West Shasta $\mathrm{Cu}-\mathrm{Zn}$ district, California: Economic Geology, v. 80, no. 8, p. 2128-2135.

Klanderman, D.S., 1978, Stratigraphy, structure, and depositional environments of the Anelope Mountain Quartzite, Yreka, California: Corvallis, Oregon State University, M.S. thesis, 115 p.

Klaseen, T.A., and Ellison, D.K., 1974, Soil survey of Shasta County area, California: U.S. Department of Agriculture, Soil Conservation Service and Forest Service, and University of California Experiment Station, U.S. Government Printing Office, Washington, D.C., 160 p.

Klein, C.W., 1976, Structure and petrology of a southeastern portion of the Happy Camp Quadrangle, Siskiyou County, Northwest California: Cambridge, Harvard University, Ph.D. dissertation, 336 p.

Klein, C.W., 1976, Thrust faulting in the Klamath Mountains, northwest California: evidence at Happy Camp for the origin of the schists of Condrey Mountain: Geological Society of America, Abstracts with Programs, v. 8, no. 3, p. 388.

Klein, C.W., 1977, Thrust plates of the north-central Klamath Mountains near Happy Camp, California: California Division of Mines and Geology Special Report 129, p. 23-26.

Knowlton, F.H., 1911, Flora of the auriferous gravels of California: U.S. Geological Survey Professional Paper 73, p. 57-64.

Knutson, S., 1981, Black Mountain, Marble Mountain Wilderness: California Caver, v. 32, no. 2, p. 19-24. 
---1982, The toughest caves in the west: California Caver, v. 33, no. 3, p. 48-49.

---1985, Marble Mountains--1985: California Caver, v. 36, no. 3, p. 33-34.

---1987, Marble Mountains--Recent explorations: California Caver, v. 37, no. 3, p. 40-41.

---1989, Marble Valley project; 1988 field log: California Caver, v. 39, no. 1, p. 6-8.

---1989, Rainy Cave: California Caver, v. 39, no. 1, p. 11-16.

Koch, J.G., 1963, Late Mesozoic orogenesis and sedimentation, Klamath province, southwest Oregon coast: Madison, Wisconsin University, Ph.D. dissertation, 282 p.

---1966, Late Mesozoic stratigraphy and tectonic history, Port Orford-Gold Beach area, southwestern Oregon coast: American Association of Petroleum Geologists Bulletin, v. 50, no. 1, p. 25-71.

---1991, The Lewis diamond, a nearly forgotten diamond find in Siskiyou County, California, and relevance of its discovery site to probable nearby diamond lode: Unpublished manuscript, $13 \mathrm{p}$.

Kopf, R.W., Hurlbut, C.S., and Koivula, J.I., 1990, Recent discoveries of large diamonds in Trinity County, California: Gems and Gemology, v. 26, no. 3, p. 212-219.

Koski, R.A., 1980, Volcanogenic massive sulfide deposits in ocean-crust and island-arc terranes, northwestern Klamath Mountains, Oregon and California: Geological Society of America, Abstracts with Programs, v. 12, no. 3, p. 115.

---1981, Volcanogenic massive sulfide deposits in ocean-crust and island-arc terranes, northwestern Klamath Mountains, Oregon and California: U.S. Geological Survey Open-File Report 81-0355, p. 197-212.

Koski, R.A., and Derkey, R.E., 1981, Massive sulfide deposits in oceanic-crust and island-arc terranes of southwestern Oregon: Oregon Geology, v. 43, no. 9, p. 119-124.

Kramer, J.C., 1977, Geologic road guide along Highway 299, Redding to Willow Creek, in Guidebook to the geology of the Klamath Mountains, northern California: Geological Society of America, Cordilleran Section, 73rd Annual Meeting, Sacramento, California, Guidebook, p. 157-162.

Kramm, H.E., 1912, Geology of Harrison Gulch, in Shasta County, California: American Institute of Mining Engineering, Bulletin 67, p. 709-715; also Transaction 43, p. 233-239 (1913).

Kruttschnitt, J. Jr., 1908, Shasta and Siskiyou Counties, in The copper resources of California: California State Mining Bureau, Bulletin 50.

Kuhns, R.J., and Baitis, H.W., 1987, Preliminary study of the Turner Albright Zn-Cu-Ag-Au-Co massive sulfide deposit, Josephine County, Oregon: Economic Geology, v. 82, no. 5, p. 1362-1376.

LaFehr, T.R., 1966, Gravity in the eastern Klamath Mountains, California: Geological Society of America Bulletin, v. 77, no. 11, p. 1177-1190.

Laizure, C. McK., 1920, Trinity County: California State Mining Bureau Report 17, p. 538-544.

---192l, Redding field division: California State Mining Bureau, 17th Report of the State Mineralogist, p. 491-544. See also Del Norte County, p. 502-503; Humboldt County, p. 504-506; Shasta County, p. 514-528; Siskiyou County, p. 529-536; Trinity County, p. 538-544.

---1925, Del Norte County: California State Mining Bureau, 21st Report State Mineralogist, v. 21, no. 1, p. 281-284.

---1925, Humboldt County: California State Mining Bureau, 21st Report State Mineralogist, v. 21, no. 1, p. 295-324.

Lamey, C.A., 1948, Hirz Mountain iron-ore deposits, Shasta County, California, in Iron resources of California: California Division of Mines Bulletin 129, p. 129-136.

---1948, Shasta and California iron-ore deposits, Shasta County, California, in Iron resources of California: California Division of Mines Bulletin 129, p. 137-164.

Landon, R.E., 1927, Romerite from California: American Mineralogist, v. 12, no. 7, p. 279-283.

Langeheim, R.L., Jr., and McCutcheon, V. A., 1959, Bayhaium merriamorum, a new Permian tabulate coral from California: Journal of Paleontology, v. 33, no. 1, p. 99-102.

Lanphere, M.A., Blake, M.C., Jr., and Irwin, W.P., 1975, Early Cretaceous metamorphic age of the South Fork Mountain Schist in the northern Coast Ranges of California: Geological Society of America, Abstracts with Programs, v. 7, no. 3, p. 340.

---1978, Early Cretaceous metamorphic age of the South Fork Mountain Schist in the northern Coast Ranges of California: American Journal of Science, v. 278, no. 6, p. 798-815.

Lanphere, M.A., and Irwin, W.P., 1965, Carboniferous isotopic age of the metamorphism of the Salmon Hornblende Schist and Abrams Mica Schist, southern Klamath Mountains, California: U.S. Geological Survey Professional Paper 525-D, p. D27-D33.

---1966, Isotopic age of Salmon and Abrams Schist, Klamath Mountains, California: Geological Society 
of America Special Paper 87, p. 213.

---1967, Age of primary metamorphism of the Abrams Mica Schist, Klamath Mountains, California: Geological Society of America, Abstracts for 1966, Special Paper 101, p. 118.

---1987, In search of the Abrams Post Office: California Geology, v. 40, no. 5, p. 99-103.

Lanphere, M.A., Irwin, W.P., and Hotz, P.E., 1968, Isotopic age of the Nevada orogeny and older plutonic and metamorphic events in the Klamath Mountains, California: Geological Society of America Bulletin, v. 79, no. 8, p. 1027-1052.

---1969, Geochronology of crystalline rocks in the Klamath Mountains, California and Oregon: Geological Society of America, Cordilleran Section, 65th Annual Meeting, Program, Eugene, Oregon, pt. 3, p. 34.

Lapierre, H., 1983, Andesites riches en magnesium: temoins d'un arc insulaire devonien dans les Klamaths orientales (N. Californie), Etats-Unis: Comptes Rendus de l'Academie des Sciences de Paris, v. 296, no. 4, p. 287-290.

Lapierre, H., Albers, J.P., and Martin, P. 1983, Birth and evolution of two Paleozoic island arcs in the eastern Klamath Mountains (N. California, U.S.A.): Geological Society of America Abstracts With Programs, v. 15, no. 6, p. 621.

Lapierre, H., Albarede, F., Albers, J., Cabanis, B., and Coulon, C., 1985, Early Devonian volcanism in the eastern Klamath Mountains, California: Evidence for an immature island arc: Canadian Journal of Earth Science, v. 22, p. 214-226.

Lapierre, H., Brouxel, M., Albarede, F., Coulon, C., and Cabanis, B., 1985, The Paleozoic and Mesozoic volcanism in the eastern Klamath Mountains (N. California, USA) - Part I: The Early Devonian intra-oceanic island-arc series: Terra Cognita - the Earth, v. 5, p. 320.

Lapierre, H., Brouxel, M., Albarede, F., Coulon, C., Lecuyer, C., Martin, P., Mascle, G., and Roure, O., 1987, Paleozoic and Lower Mesozoic magmas from the eastern Klamath Mountains (Northern California) and the geodynamic evolution of northwestern America: Tectonophysics, v. 140, p. 155-177.

Lapierre, H., Brouxel, M., Martin, P., Coulon, C., Mascle, G., and Cabanis , B., 1986, The Paleozoic and Mesozoic geodynamic evolution of the eastern Klamath Mountains (Northern California) inferred from its magmatism: Bulletin de la Societe geologique de France, v. 8, II, p. 969-980.

Lapierre, H., and Cabanis, B., 1985, Caracterisation d'une serie tholeitique d'arc d'age Paleozoique (Klamaths orientales, Nord Californie, U.S.A.) a l'aide des clinopyroxenes et des elements en traces: Bulletin de la Societe geologique de France, v. 8, p. 541-552.

Lapierre, H., Cabanis, B., Coulon, C., Brouxel, M., and Albarede, F., 1985, Geodynamic setting of Early Devonian Kuroko-type sulfide deposits in the eastern Klamath Mountains (northern California) inferred by the petrological and geochemical characteristics of the associated island-arc volcanic rocks: Economic Geology, v. 80, no. 8, p. 2100-2113.

Lapierre, H., Charvet, J., Rouer, O., Coulon, C, and Campos, C., 1990, Plate tectonic models proposed for the cordillera geodynamic evolution (N. California and Oregon) during Paleozoic and early Mesozoic time, in Aubouin, Jean, and Bourgois, Jacques, eds., Tectonics of circum-Pacific continental margins: Proceedings of the 28th International Geological Congress, 9-19, July, 1989: VSP, Utrecht, The Netherlands, p. 1-35.

Lapierre, H., Charvet, J., Rouer, O., and Coulon, C., 1990, Model for the geodynamic evolution of the western North American Cordillera during Paleozoic and early Mesozoic, in Wiley, T.J., Howell, D.G., and Wong, F.L., eds., Terrane analysis of China and the Pacific rim: Houston, Texas, CircumPacific Council for Energy and Mineral Resources, Earth Science Series, v. 13, p. 103-131.

Lapierre, H., Charvet, J., Rouer, O., Lecuyer, C., Coulon, C., Howell, D.G., and Campos, C., 1989, Plate tectonic models proposed for the Cordillera geodynamic evolution (N. California, Oregon, and Nevada) during Paleozoic and Mesozoic times: 28th International Geological Congress abstracts, v. 2, p. 2.258-2.259.

Larson, C., and Larson, J., 1976, Caves of Oregon: Oregon Speleological Survey, Bulletin No. 4 (Western Speleological Survey Serial No. 49), p. 40.

Laudermilk, J.D., and Woodford, A.O., 1930, Soda-rich anthophyllite from Trinity County, California: American Mineralogist, v. 15, no. 7, p. 259-262.

Lawson, A.C., 1941, Memorial to Oscar H. Hershey, in Proceedings of the Geological Society of America for 1940: Geological Society of America, p. 195-200.

Lawson, W.A., 1986, Geology and structure of the Covington Mill 7.5 minute quadrangle, Trinity County, CA: San Jose, California State University, M. S. thesis, 101 p. 
Leach, F.A., 1899, Fineness of California gold, in California mines and minerals: California Miner's Association, Souvenir edition, Louis Roesch Company, San Francisco, California, p. 175-187.

Leavell, D.N., 1979, The geology and distribution of Josephinite in the Josephine Peridotite, southwest Oregon: Eos (American Geophysical Union Trans.), V. 60, NO. 46, p. 970.

Lécuyer, C., 1990, Hydrothermalisme fossile dans une paleocroûte océanique associee a un centre d'expansion lent; le complexe ophiolitique de Trinity (N. California, U.S.A.): Thèse de l' Université de Rennes I Mem. Doc. CAESS 33, 279 p.

---1990, Chemical transfer between mantle xenoliths and basic magmas; evidence from oceanic magma chambers: The Trinity ophiolite (northern California); Lithos, v. 25, no. 4, p. 243-259.

Lécuyer, C., and Brouxel, M., 1988, Diversity and petrogenesis of magmas in the Trinity Ophiolite (California): Geological Society of America Abstracts with Programs, v. 20, no. 7, p. 157.

Lécuyer, C, Brouxel, M., and Albarède, F., 1990, Elemental fluxes during hydrothermal alteration of the Trinity ophiolite (California, USA) by seawater: Chemical Geology, v. 89, no. 1-2, p. 87-115.

Lecuyer, C., Brouxel, M., and Lapierre, H., 1991, Petrogenesis of magmas at a fossil slow-spreading center: The Trinity ophiolite (northern California, USA): Bulletin de la Societe geologique de France, v. 162, no. 5, p. 795-809.

Ledoux, A.R., 1901, Notes on the Oregon nickel prospects: Canadian Mining Institute J4, p. 184-189; also Canadian Mining Revue 20, p. 84-85.

Leikam, D.E.R., Karambela, K.K., Giaramita, M.J., and Harper, G.D., 2002, Petrography and geochemistry of new pillow lava and dike localities, Elk River aarea, southwestern Oregon: Geological Society of America, Abstracts with Programs, v. 34, no. 5, p. A-28.

Lee, G.K., 1972, Glaciation of the Red Mountain area, Klamath Mountains, California: Tempe, Arizona State University, M.Sc. thesis, 91 p.

Lehre, A.K., 1980, Effect of large organic debris on morphology of undisturbed steep mountain channels in Douglas fir forest, South Fork Smith River drainage, California: Geological Society of America, Abstracts with Programs, v. 12, no. 3, p. 116.

LeRoy, T.H., 1993, General reconnaissance of the northeast side of Hyampom Valley: Evidence for a Late Cenozoic structural basin, southeastern Klamath Mountains, California: Humboldt State University, B.Sc. thesis, 23 p.

LeSueur, E., and Boudier, F., 1986, Structures du complexe basique et ultrabasique de Trinity, Californie: genese d'une ophiolite atypique: Bulletin de la Societe geologique de France, v. 8, II, p. 1007-1014.

LeSueur, E., Boudier, F., Cannat, M., Ceuleneer, G., and Nicolas, A., 1984, The Trinity mafic-ultramafic complex: First results of the structural study of an untypical ophiolite: Ofioliti, v. 9, no. 3, p. 487-497.

LeSueur, E., Boudier, F., Ceuleneer, G., and Nicolas, A., 1984, Trinity mafic-ultramafic complex: results of a structural study of an untypical ophiolite: Terra Cognita, v. 5, p. 185-186.

Lewison, M.A., 1983, Fission track ages of two plutons in the central Klamath Mountains, California: Eugene, University of Oregon, M.S. thesis, 76 p.

Libbey, F.W., 195l, Comments on the geology and mineral resources of Douglas County, Oregon: Ore Bin, v. 13 , no. 2 , p. 9-13.

---1957, Limestone resources of the Pacific Northwest: Raw Materials Survey Research Report, no. 9, 92 p.

---1963, Lest we forget: Ore Bin, v. 25, no. 6, p. 93-109.

---1967, The Almeda mine, Josephine County, Oregon: Oregon Department of Geology and Mineral Industries Short Paper 24, $53 \mathrm{p}$.

Libbey, F.W., and others, 1942, Manganese in Oregon: Oregon Department of Geology and Mineral Industries Bulletin 17, $78 \mathrm{p}$.

Lieberman, J.L., 1983, Petrology and petrogenesis of marble and peridotite, Seiad Valley Complex, California: Eugene, University of Oregon, M. S. thesis, 119 p.

Lieberman, J.L., and Rice, J.M., 1983, Prograde metamorphism of marble and peridotite in the Seiad ultramafic complex, California: Geological Society of America, Abstracts with Programs, v. 15, no. 5 , p. 436.

---1986, Petrology of marble and peridotite in the Seiad ultramafic complex, northern California, USA: Journal of Metamorphic Geology, v. 4, no. 2, p. 179-199.

Lindberg, P.A., 1985, A volcanogenic interpretation for massive sulfide origin, West Shasta district, California: Economic Geology, v. 80, no. 8, p. 2240-2254.

Lindsley-Griffin, N., 1973, Lower Paleozoic ophiolite of the Scott Mountains, eastern Klamath 
Mountains, California: Geological Society of America, Abstracts with Programs, v. 5, no. 1, p. 71-72.

---1975, Geology of the northwestern edge of the Trinity ophiolite, eastern Klamath Mountains, California: Eos (American Geophysical Union Trans.) v. 56, no. 12, p. 1079.

---1976, Feldspathic lherzolites of the Trinity ophiolite complex, eastern Klamath Mountains, California: Eos (American Geophysical Union Trans.), v. 57, no. 12, p. 1025.

---1977, The Trinity Ophiolite, Klamath Mountains, California, in Coleman, R. G., and Irwin, W.P., eds., North American ophiolites: Oregon Department of Geology and Mineral Industries, Bulletin 95, p. 107-120.

---1977, Early Paleozoic subduction complex in the eastern Klamath Mountains: implications for Cordilleran tectonic models: Geological Society of America, Abstracts with Programs, v. 9, no. 4, p. 454.

---1977, Paleogeographic implications of ophiolites: The Ordovician Trinity complex of the Klamath Mountains, northern California, in Stewart, C.H., Stevens, C.H., and Fritsche, A.E., eds., Paleozoic paleogeography of the western United States: Society of Economic Paleontologists and Mineralogists, Pacific Section, Pacific Coast Paleogeography Symposium 1, p. 409-420.

---1982, Structure, stratigraphy, petrology, and regional relationships of the Trinity ophiolite: Davis, University of California, Ph.D. dissertation, $453 \mathrm{p}$.

---1983, Structure, stratigraphy, petrology and regional relationships of the Trinity ophiolite, eastern Klamath Mountains, California: Dissertation Abstracts International, v. 44, 2, p. 436-B.

---1983, Lower Paleozoic rocks of the eastern Klamath Mountains, northern California: constraints on early Paleozoic paleogeography: Geological Society of America, Abstracts with Programs, v. 15, no. 5 , p. 426.

---1984, Deformational styles of melanges in accretionary complexes: Geological Society of America, Abstracts with Programs, v. 16, no. 6, p. 576.

---1991, The Trinity complex: A polygenetic ophiolitic assemblage in Cooper, J.D. and Stevens, C.H., eds., Paleozoic Paleogeography of the Western United States II: Society of Economic Paleontologists and Mineralogists, Pacific Section, v. 67, p.589-607.

---1992, The ophiolitic lower Paleozoic Trinity Complex of northern California, U.S.A.: 29th International Geological Congress, Kyoto Japan, Abstracts, v. 1, p. 133.

---1994, The Cambrian Trinity ophiolite and related rocks of the lower Paleozoic Trinity Complex, northern California, U.S.A.: in Ishiwatari, A., Malpas, J., and Ishizuka, H., eds., Ophiolites of the circum-Pacific region: VSP International Science Publishers, The Netherlands, Proceedings of the 29th International Geological Congress, Part D, p. 47-68.

Lindsley-Griffin, N., Farmer, J.D., and Griffin, J.R., 2002, Ediacaran Cyclomedusids from an accreted terrane in the eastern Klamath Mountains, CA: Geological Society of America, Abstracts with Programs, v. 34, no. 6, p. 272.

Lindsley-Griffin, N., and Fisher, M., 1989, Significance of the tectonic contact between lower Paleozoic melange and shales of the Gazelle Formation, Yreka terrane, Klamath Mountains, California: Geological Society of America, Abstracfts with Programs, v. 21, no. 5, p. 107.

Lindsley-Griffin, N., and Griffin, J.R., 1983, The Trinity terrane: An early Paleozoic microplate assemblage, in C.H. Stevens, ed., Pre-Jurassic rocks in western North American suspect terranes: Society of Economic Paleontologists and Mineralogists, Pacific section, p. 63-75.

Lindsley-Griffin, N., Griffin, J.R., and De La Fuente, J., 1989, Unidentified fossil-like objects (UFO's) from the Antelope Mountain Quartzite, lower Paleozoic Yreka terrane, Klamath Mountains, California: Geological Society of America, Abstracts with Programs, v. 21, no. 5, p. 107.

Lindsley-Griffin, N, Griffin, J.R., and Farmer, J.D., 2003, Significance of Ediacaran cyclomedusids and other Pacific rim biota in the Yreka terrane, eastern Klamath Mountains, California: Geological Society of America, Abstracts with Programs, v., 35, no. 4, p. 14.

Lindsley-Griffin, N., Griffin, J.R., and Wallin, E.T., 1991, Redefinition of the Gazelle Formation of the Yreka terrane, Klamath Mountains, California: Paleographic implications: in Cooper, J.D. and Stevens, C.H., eds., Paleozoic Paleogeography of the Western United States II: Society of Economic Paleontologists and Mineralogists, Pacific Section, v. 67, p. 609-624.

Lindsley-Griffin, N., Griffin, J.R., Wetzstein, E.E., and Jameossanaie, A., 1993, Post-accretion history and paleogeography of a Cretaceous overlap sequence in northern California, in Dunn, G., and McDougall, K., eds., Mesozoic paleogeography of the western United States-II: Society of Economic Paleontologists and Mineralogists, Pacific Section, Book 71, p. 99-112. 
Lindsley-Griffin, N., and Kramer, J.C., eds., 1977, Geology of the Klamath Mountains, northern California: Geological Society of America, Cordilleran Section, 73rd Annual Meeting, Sacramento, Calif., Guidebook, 162 p.

Lindsley-Griffin, N., and Rohr, D.M., 1977, Lovers Leap: a geologic puzzle, in Geology of the Klamath Mountains, northern California: Geological Society of America, Cordilleran Section, 73rd Annual Meeting, Sacramento, California, Guidebook, p. 47-69.

---1977, Bibliography of the Trinity complex and the eastern Klamath Mountains, northern California, in Lindsley-Griffin, N., and Kramer, J.C. , eds., Geology of the Klamath Mountains, northern California: Geological Society of America Cordilleran Section, Field Trip Guidebook:, p. 104-111.

Lindsley-Griffin, N., Rohr, D.M., Griffin, J.R., and Moores, E.M., 1974, Geology of the Lovers Leap Area, eastern Klamath Mountains, California, in Geological guide to the Klamath Mountains: Geological Society of Sacramento, Annual Field Trip Guidebook, p. 82-100.

Lipin, B.R., Wetzel, N., and Heinrich, S.M., 1983, The Emma Bell deposit, Siskiyou County, California, a possible low-grade source of chromite: U.S. Geological Survey, Open-File Report 830816, $16 \mathrm{p}$

Lipman, P.W., 1962, Geology of the southeastern Trinity Alps, northern California: Stanford, California, Stanford University, Ph.D. dissertation, $210 \mathrm{p}$.

---1962, Isoclinal folding and metamorphism in the eastern Trinity Alps, northern California: Geological Society of America Special Paper 68, p. 38.

---1963, Gibson Peak pluton--A discordant composite intrusion in the southeastern Trinity Alps, northern California: Geological Society of America Bulletin , v. 74, no. 10, p. 1259-1280.

---1964, Mineralogy and paragenesis of amphiboles from Gibson Peak pluton, northern California: American Mineralogist, v. 49, nos. 9-10, p. 1321-1330.

---1964, Structure and origin of an ultramafic pluton in the Klamath Mountains, California: American Journal of Science, v. 262, p. 199-222.

---1964, Structure and petrology of Canyon Creek pluton, Trinity Alps, northern California: Geological Society of America Special Paper 76, p. 280-281.

---1964, Two contrasting groups of ultramafic intrusions in northwestern California: Geological Society of America Special Paper 76, p. 103.

---1992, Magmatism in the Cordilleran United States; Progress and problems, in Burchfiel, B.C., Lipman, P.W., and Zoback, M.L., eds., The Geology of North America Volume G-3, The Cordilleran Orogen: Conterminous U.S.: Geological Society of America, Boulder, Colorado, p. 481514.

Logan, C.A., 1919, Platinum and allied metals in California: California State Mining Bureau Bulletin $85,120 \mathrm{p}$.

---1924, Sacramento field division, Shasta and Siskiyou Counties: California State Mining Bureau, 20th Report State Mineralogist, p. 15-17; 179-183.

---1925, Siskiyou County: California State Mining Bureau, 21st Report State Mineralogist, v. 21, no. 1, p. 413-498.

---1926, Sacramento Field Division, Shasta County: California State Mining Bureau, 22nd Report State Mineralogist, p. 121-216.

---1926, Sacramento Field Division, Trinity County: California State Mining Bureau, 22nd Report State Mineralogist, p. 1-67.

---1947, Limestone in California: California Journal of Mines and Geology, v. 43, p. 175-357.

Loney, R.A., and Himmelberg, G.R., 1976, Structure of the Vulcan Peak alpine-type peridotite, southwestern Oregon: Geological Society of America Bulletin, v. 87, p. 259-274.

---1977, Geology of the gabbroic complex along the northern border of the Josephine Peridotite, Vulcan Peak area, southwestern Oregon: U.S. Geological Survey, Journal of Research, v. 5, no. 6, p. 761-781.

Loomis, T.P., and Gottschalk, R.R., 1981, Hydrothermal origin of mafic layers in alpine-type peridotites---evidence from the Seiad ultramafic complex, California, U. S. A.: Contributions to mineralogy and petrology, v. 76, p. 1-11.

Louderback, G.D., 1928, Geologic features of Kennett dam site: California Department of Public Works, Division of Engineering and Irrigation, Bulletin 13, p. 56-59.

Lowden, W.S., 1900, Register of mines and minerals, County of Trinity, California: California State Mining Bureau, $25 \mathrm{p}$.

Lowell, F.L., 1916, The counties of Del Norte, Humboldt, and Mendocino, in 14th Report of the State 
Mineralogist: California State Mining Bureau, p. 371-425.

Lowell, W.R., 1942, The paragenesis of some gold and copper ores of southwestern Oregon: Economic Geology, v. 37, no. 7, p. 557-595.

Luken, M.D., 1985, Petrography and origin of limestones in the Western Paleozoic and Triassic belt, Klamath Mountains, California: San Jose, California State University, M.Sc. thesis, 130 p., 15 plates.

Luken, M., Stevens, C.H., and Magginetti, R., 1985, Permian faunal relationships across California: Geological Society of America, Abstracts with Programs, v. 17, no. 6, p. 367.

Lund, E.H., and Baldwin, E.M., 1969, Diorite intrusions between Sixes and Pistol Rivers, southwestern Oregon: Ore Bin, v. 31, no. 10, p. 193-206.

Lund, J.W., 1974, Erosion and silting problems in the Ashland Watershed, in Twelfth Annual Engineering Geology and Soils Engineering Symposium, Erickson, L.F., (ed.): Idaho Transportation Department, Division of Highways, Idaho State University, p. 275-285.

Lundquist, S.M., 1982, Deformation history of the ultramafic and associated metamorphic rocks of the Seiad Complex, Seiad Valley, California: Seattle, University of Washington, M.S. thesis, 167 p.

Lydon, P.A., 1963, A trip in Shasta County: California Division of Mines and Geology Mineral Information Service, v. 16, no. 12, p. 6-7.

---1964, Cenozoic volcanic flows in the Klamath Mountains of California: Geological Society of America Special Paper 76, p. 212.

---1964, "Silicate slag" from Trinity County: California Division of Mines and Geology, Mineral Information Service, v. 17, no. 6, p. 99-106.

---1964, Unusual phosphatic rock--New deposit near Hyampom opens economic possibilities: California Division of Mines and Geology, Mineral Information Service, v. 17, no. 5, p. 65-74.

Lydon, P.A., Gay, T.E., Jr., and Jennings, C.W., 1960, Geologic map of California, Westwood Sheet--Olaf P. Jenkins edition: California Division of Mines and Geology Map Sheet, scale $1: 250,000$.

Lydon, P.A., and Klein, I.E., 1969, Geology of the southeast quarter of Trinity Lake quadrangle, Trinity County, California: California Division of Mines and Geology Map Sheet 12, scale 1:24,000.

Lydon, P.A., and O'Brien, J.C., 1974, Mines and mineral resources of Shasta County, California: California Division of Mines and Geology, County Report 6, 154 p.

MacDonald, D.F., 1910, The Weaverville-Trinity Center gold gravels, Trinity County, California: U.S. Geological Survey Bulletin 430, p. 48-58.

---1913, Notes on the gold lodes of the Carrville district, Trinity County, California: U.S. Geological Survey Bulletin 530, p. 9-41.

MacDonald, D.C., 1986, Gold and silver telluride mineralization at the Reid Mine, Shasta County, California: Knoxville, University of Tennessee, M.Sc. thesis, 136 p.

MacGinitie, H.D., 1934, Ecological aspects of the floras of the auriferous gravels: Geological Society of America Proceedings, 1933, p. 356.

---1935, Tertiary floras of Trinity County, California: Geological Society of America Proceedings, 1934, p. 390.

---1937, The flora of the Weaverville beds of Trinity County, California; with descriptions of the plant-bearing beds, in Eocene flora of western America: Carnegie Institute of Washington Contributions to Paleontology, Publication 465, p. 83-151.

---1938, Geologic relations along the southwest border of the Klamath Mountains: Geological Society of America Proceedings 1937, p. 247.

MacGregor, A., 1890, Del Norte County [p. 166-168], and Shasta Count[p. 627-641] in 10th Annual Report of the State Mineralogist: California State Mining Bureau.

Mack, G.S., 1982, Chemistry of ground waters associated with the Grants Pass Batholith, Klamath Mountains, Oregon: Geological Society of America, Abstracts with Programs, v. 14, no. 4, p. 183.

---1982, Geology, ground water chemistry, and hydrogeology of the Murphy area, Josephine County, Oregon: Corvallis, Oregon State University, M.Sc. thesis, 130 p.

Mack, S., 1958, Geology and ground-water features of Scott Valley, Siskiyou County, California: U.S. Geological Survey Water-Supply Paper 1462, 98 p.

---1958, Geology and ground-water resources of Scott and Shasta Valleys, Siskiyou County, California: Dissertation Abstracts v. 18, no. 1, p. 197.

---1960, Geology and ground-water features of Shasta Valley, Siskiyou County, California: U.S. Geological Survey Water Supply Paper 1484: 115 p. 
Madrid, R.J., Poole, F.G., and Miller, M.M., 1992, Devonian and older rocks in accreted terranes, in Burchfiel, B.C., Lipman, P.W., and Zoback, M.L., eds., The Geology of North America Volume G-3, The Cordilleran Orogen: Conterminous U.S.: Geological Society of America, Boulder, Colorado, p. 36-43.

Magginetti, R.T., 1984, Presence of "Klamath type" fusulinids in the cordilleran miogeosyncline of eastern California: Geological Society of America, Abstracts with Programs, v. 16, no. 6, p. 582.

Magill, J., and Cox, A., 1981, Post-Oligocene tectonic rotation of the Oregon western Cascade Range and the Klamath Mountains: Geology, v. 9, no. 3, p. 127-131.

Malone, K., Benson, W.T., and Engel, A.L., 1962, Mount Eddy and Shasta View asbestos deposits, Siskiyou County, California: U.S. Bureau of Mines Report Investigation 5948, 29 p.

Mankinen, E.A., Gromme, C.S., and Irwin, W.P., 1985, Paleomagnetic constraints on the accretionary history of the Klamath Mountains province, California and Oregon: Eos (American Geophysocal Union Trans.), v. 66, no. 46, p. 863.

Mankinen, E.A., and Irwin, W.P., 1982, Paleomagnetic study of some Cretaceous and Tertiary sedimentary rocks of the Klamath Mountains province, California: Geology, v. 10, no. 2, p. 82-87.

---1990, Review of paleomagnetic data from the Klamath Mountains, Blue Mountains, and Sierra Nevada; Implications for paleogeographic reconstructions, in Harwood, D.S., and Miller, M.M., eds., Paleozoic and early Mesozoic paleogeographic relations; Sierra Nevada, Klamath Mountains, and related terranes; Geological Society of America Special Paper 255, p. 397-409.

Mankinen, E.A., Irwin, W.P., and Blome, C.D., 1996, Far-travelled Permian chert of the North Fork terrane, Klamath Mountains, California: Tectonics, v. 15, no. 2, p. 314-328.

Mankinen, E.A., Irwin, W.P., and Gromme, C.S., 1982, Tectonic rotation of the Eastern Klamath Mountains terrane: Eos (American Geophysical Union Trans.), v. 63, no. 45, p. 914.

---1984, Tectonic rotations suggested by paleomagnetic studies of the Eastern Klamath terrane: Society of Economic Paleontologist and Mineralogists, Pacific Section, San Diego meeting, April 1984, Abstracts, p. 94-95.

---1984, Implications of paleomagnetism for the tectonic history of the Eastern Klamath and related terranes in California and Oregon, in Nilsen, T. H., ed., Geology of the Upper Cretaceous Hornbrook Formation, Oregon and California: Society of Economic Paleontologists and Mineralogists, Pacific Section, v. 42, p. 221-229.

---1988, Paleomagnetic results from the Shasta Bally plutonic belt in the Klamath Mountains province, northern California: Geophysical Research Letters, v. 15, no. 1, p. 56-59.

---1989, Paleomagnetic study of the Eastern Klamath terrane, California, and implications for the tectonic history of the Klamath Mountains province: Journal of Geophysical Research, v. 94, no. B8, p. 10444-10472.

Mankinen, E.A., Lindsley-Griffin, N., and Griffin, J.R., 2002, Concordant paleolatitudes for Neoproterozoic ophiolitic rocks of the Trinity Complex, Klamath Mountains, California: Journal of Geophysical Research, v. 107, B10, EPM 11, p. 1-18

Martin, A.H., 1908, Mining and smelting on Shasta copper belt, California: Mining World, v. 29, p. 309-311.

---1910, The east side of the Shasta copper belt, California: Mining World, v. 32, p. 99-100.

Martin, P., 1983, Un jalon dan l'evolution geodynamique de la bordure ouest americaine. La serie volcanique permienne de Nosoni (klamath orientales California): D.E.A. de petrologie, Universite de Nancy I, $32 \mathrm{p}$.

---1989, Le volcanisme permien d'arc insulaire des Klamath orientales (Californie, USA): Petrogenese et implications geodynamiques (These d'Universite; Nancy, France, Universite de Nancy I, 172 p.

Martin, P., Lapierre, H., and Coulon, C., 1985, The Paleozoic and Mesozoic volcanism in the eastern Klamath Mountains (N. California, USA) - Part II: The Permo Triassic island-arc series: Terra Cognita - the Earth, v. 5, p. 320.

Martin, P., Lapierre, H., and Rocci, G., 1984, Présence d'un arc insulaire permien dans les Klamath orientales (N. Californie, U.S.A.): Comptes Rendus de l'Académie des Sciences de Paris, II, v. 298, no. 6, p. 223-228.

Masi, V., O'Neil, J.R., and Kistler, R.W., 1981, Stable isotope systematics in Mesozoic granites of central and northern California and southwestern Oregon: Contributions to Mineralogy and Petrology, V. 76, no. 1, p. 116-126.

Mason, R. S., 1949, Exploration of nickel-bearing laterite on Woodcock Mountain, Josephine County, Oregon: The Ore.-Bin, v. 11, no. 3, p. 15-20. 
Masson, P.H., 1949, Geology of the Gunsight Peak district, Siskiyou County, California: Berkeley, California University, M.A. thesis, 74 p.

---1990, Sheeted dikes in the Trinity ophiolite, northern California: Geological Society of America, Abstracts with Programs, v. 22, no. 3, p. 64.

---1991, Grey Rocks, a remnant of a submarine volcano in the Trinity Complex, northern California: Geological Society of America, Abstracts with Programs, v. 23, no. 2, p. 76.

---1993, New evidence for early Paleozoic orogeny in the eastern Klamath terrane, northern California: Geological Society of America, Abstracts with Programs, v. 25, no. 5, p. 115.

---2002, Revised geology of the Grey Rocks outlier, southeast Klamath Mountains, California: Geological Society of America, Abstracts with Programs, v. 34, no. 5, p. A-43

Mattinson, J.M., and Hopson, C.A., 1972, Paleozoic ages of rocks from ophiolitic complexes in Washington and northern California: Eos (American Geophysical Union Trans.), v. 53, no. 4, p. 543.

---1972, Paleozoic ophiolitic complexes in Washington and northern California: Carnegie Inst., Annual Report of the Director, Geophysical Laboratory, 1971-1972, p. 578-583.

Matzner, D.M., 1986, Metamorphism of early Paleozoic island arc and Mesozoic plutonic rocks intruding the Trinity peridotite, eastern Klamath Moountains, California: Los Angeles, California University, M.Sc. thesis.

Maxson, J.H., 1931, Geology of the western Siskiyou Mountains, northwestern California: Pasadena, California Institute of Technology, Ph.D. dissertation, 226 p.

---1932, Geomorphic features of northwesternmost California: Geological Society of America Bulletin, v. 43 , no. 1, p. 224.

---1933, Contact conditions of some chromite deposits in serpentine in Klamath Mountains: Geological Society of America Bulletin, v. 44, pt. 1, p. 166.

---1933, Economic geology of portions of Del Norte and Siskiyou Counties, northwesternmost California: California Journal of Mines and Geology, v. 29, nos. 1, 2, p. 123-160.

---1933, Structural relationships of coast and continental margin of northern California: Geological Society of America Bulletin, v. 44, pt. 1, p. 152.

Maxwell, J.C., 1974, Anatomy of an orogen: Geological Society of America Bulletin, v. 85, p. 1195-1204.

---1974, Early western margin of the United States, in The geology of continental margins: Springer-Verlag, New York, Inc., p. 831-852.

Maytum, J.R., 1967, Areal geology of southeast portion Chanchelulla Peak quadrangle, California: San Diego, California State College, M.S. thesis, $113 \mathrm{p}$.

McAtee, J.L., Jr., House, R., and Engster, H.P., 1968, Magadiite from Trinity County, California: American Mineralogist, v. 53, nos. 11-12, p. 2061-2069.

McCormick, M., 1986, Facies analysis and environmental paleointerpretation of the Upper Triassic Hosselkus Limestone, Shasta County, California: Berkeley, California University, M.Sc. thesis.

McDonald, D.C., 1986, Gold and silver telluride mineralization at the Reid mine, Shasta County, California: Knoxville, University of Tennessee, M.Sc. thesis.

McDonald, D.F., 1910, The Weaverville-Trinity Center gold gravels, Trinity County, California: U.S. Geological Survey Bulletin 430, p. 48-58.

McGeary, D.F.R., Editor, 1974, Geologic guide to the southern Klamath Mountains: Geological Society of Sacramento Annual Field Trip Guidebook, 131 p.

McGeary, D.F.R., Kramer, C.J., Plummer, C.C., and Lindsley-Griffin, N., 1974, Road log, Scott Valley-Lover's Leap-Yreka-Redding, in D.F.R. McGeary, ed., Geologic guide to the southern Klamath Mountain: Geological Society of Sacramento, Annual Field trip Guidebook, p. 126-129.

McGeary, D.F.R., Kramer, C.J., Plummer, C.C., Cashman, P.H., and Seyfert, C.K., 1974, Road log, Willow Creek-Somes Bar-Forks of Salmon-Sayers Bar-Etna, in D.F.R., McGeary, ed., Geologic guide to the southern Klamath Mountains: Geological Society of Sacramento, Annual Field Trip Guidebook, p. 121-125.

McGregor, A., 1890, Del Norte County: California State Mining Bureau, 10th Report State Mineralogist, p. 166-168.

---1890, Humboldt County: California State Mining Bureau, 10th Report State Mineralogist, p. 205-208.

---1890, Shasta County: California State Mining Bureau, 10th Report State Mineralogist, p. 627-641.

McHuron, E.J., and Rice, R.H., 1988, Landslides versus river terraces, Gasquet Mountain, northwestern California: Geological Society of America, Abstracts with Programs, V. 20, no. 3, p. 213.

McKee, B., 1972, The Klamath Mountains of Oregon, Chapter 10, in Cascadia--the geologic evolution of 
the Pacific Northwest: McGraw-Hill, Inc., p. 139-152.

McKee, E.D., and others, 1956, Paleotectonic maps of the Jurassic system: U.S. Geological Survey, Miscellaneous Geological Investigations Map I-175.

McKnight, B.K., 1964, Stratigraphic study of Cretaceous rocks near Mitchell, Oregon: Geological Society of America, Program, Seattle, Washington, p. 44.

---1971, Petrology and sedimentation of Cretaceous and Eocene rocks in the Medford-Ashland region, southwestern Oregon: Corvallis, Oregon State University, Ph.D. dissertation, 196 p.

McNutt, M.K., 1983, Influence of plate subduction on isostatic compensation in northern California: Tectonics, v. 2, no. 4, p. 399-415.

Medaris, L.G., Jr., 1966, Geology of the Seiad Valley area, Siskiyou County, California, and petrology of the Seiad ultramafic complex: Los Angeles, California State University, Ph.D. dissertation, $333 \mathrm{p}$.

---1966, High-temperature metamorphic rocks associated with an ultramafic complex, Siskiyou County, California: Geological Society of America, Special Paper 87, p. 108.

---1969, Coexisting olivine, pyroxene, and spinel in the Seiad ultramafic complex, Siskiyou County, California: Eos (American Geophysical Union Trans.), v. 50, no. 4, p. 333.

---1972, High-pressure peridotites in southwestern Oregon: Geological Society of America Bulletin, v. 83, no. 1, p. 41-57.

---1976, Application of pyroxene and olivine-spinel geothermometry to recrystallized alpine peridotites in the Klamath Mountains province: Eos (American Geophysical Union Trans.) v. 57, no. 12 , p. 1025.

Medaris, L.G., Jr., and Dott, R.H., Jr., 1970, Mantle-derived peridotites in southwestern Oregon: relation to plate tectonics: Science, v. 169, p. 971-974.

---1973, Interpretation of "ophiolites" and "flysch" in the Klamath--Coast Range Region: Geological Society of America, Abstracts with Programs, v. 5, no. 1, p. 79.

Medaris, L.G., Jr., Welsh, J.L., Ferns, M.L., and Kays, M.A., 1980, Prograde metamorphism of serpentinites in the western Paleozoic and Triassic belt, Klamath Mountains Province: Geological Society of America, Abstracts with Programs, v. 12, no. 3, p. 120.

Meek, F.B., 1864, Description of the carboniferous fossils, in Paleontology of California: Geological Survey of California, v. 1, p. 3-16.

Meibom, A., and Frei, R., 2002, Evidence for an ancient osmium isotopic reservoir in Earth: Science, v. 296, p. 516-518.

---2002, Correction [re evidence for an ancient osmium isotopic reservoir]: Science, v. 297, p. 1120.

Merriam, C.W., 1961, Silurian and Devonian rocks of the Klamath Mountains, California, in Geological Survey Research, 1961: U.S. Geological Survey Professional Paper 424-C, p. C188-C190.

---1972, Silurian rugose corals of the Klamath Mountains region, California: U.S. Geological Survey Professional Paper 738, 50 p.

Merriam, J.C., 1895, Some reptilian remains from the Triassic of northern California: American Journal of Science (3), v. 50, p. 55-57.

---1902, Triassic Icthyopterygia from California and Nevada: California University Publications Geological Science, v. 3, no. 4, p. 63-108: reprinted in 1938, in Published papers and addresses of John Campbell Merriam, Carnegie Institute Washington, Publication no. 500, v. 1, p. 66-108.

---1903, New Icthyosauria from the Upper Triassic of California: California University Publications Geological Science, v. 3, no. 12, p. 249-263: reprinted in 1938 in Published papers and addresses of John Campbell Merriam, Carnegie Institute Washington, Publication no. 500, v. 1, p. 110-124.

---1904, A new marine reptile from the Triassic of California: California University Publications Geological Science, v. 3, no. 21, p. 419-421: reprinted in 1938, in Published papers and addresses of John Campbell Merriam, Carnegie Institute Washington, Publication no. 500, v. 1, p. 130-132.

---1905, The Thalattosauria--a group of marine reptiles from the Triassic of California: California Academy of Science Memoir, v. 5, no. 1, p. 1-52: reprinted 1938, Published papers and addresses of John Campbell Merriam, Carnegie Institute Washington, Publication no. 500, v. 1, p. 149-191.

---1906, Recent cave explorations in California: American Anthropologist, series 2, v. 8, no. 2, p. 221-228: reprinted in 1938, in Published papers and addresses of John Campbell Merriam, Carnegie Institute Washington, Publication no. 500, v. 3, p. 1540-1547.

---1908, Triassic Icthyosauria--with special reference to the American forms: California University Memoir v. 1, no. 1, p. 1-196: reprinted 1938, Published papers and addresses of John Campbell 
Merriam, Carnegie Institute Washington, Publication no. 500, v. 1, p. 207-391.

---1927, The cave of the magic pool: Scribner's Magazine, v. 82, no. 3, p.264-272: reprinted in 1938, in Published papers and addresses of John Campbell Merriam, Carnegie Institute Washington, Publication no. 500, v. 3, p. 1877-1886.

Merriam, J.C., and Stock, C., 1925, Relationships and structure of the short-faced bear, Arctotherium, from the Pleistocene of California: Carnegie Institute of Washington Pub. no 347, paper 1, p. 1-35: reprinted in 1938 in Published papers and addresses of John Campbell Merriam, Carnegie Institute Washington, Publication no. 500, v. 3, p. 1489-1527.

Merriam, R.H., 1945, Magmatic differentiation in gabbro sills near Ashland, Oregon: American Journal of Science, v. 243, no. 8, p. 456-465.

Metcalf, R.V., and Barrow, W., 2002, Paleozoic-Mesozoic subduction related crustal growth in the Klamath Mountains: A view from the eastern Klamath terrane: Geological Society of America, Abstracts with Programs, v. 34, no. 5, p. A-43.

Metcalf, R.V., and Wallin, E.T., 1996, Supra-subduction zone paleotectonic setting of the Trinity terrane and the onset of Paleozoic subduction, Klamath Mountains California: Geological Society of America, Abstracts with Programs, v. 28, no. 5, p. 91.

Metcalf, R.V., Wallin, E.T., Willse, K., 1998, Devonian volcanic rocks of the eastern Klamath Mountains: An island-arc or volcanic cover of the Trinity ophiolite?: Geological Society of America, Abstracts with Programs, v. 30, no. 5, p. 54.

Metcalf, R.V., Willse, K.R., and Wallin, E.T., 1999, Trace element and Nb-Sr-Pb isotopic data from the Silurian Bonanza King complex, Trinity terrane, CA: Evidence of supra-subduction zone magmatism in a proto-arc paleotectonic setting: Geologic Society of America, Abstracts with Programs, v. 31, no. 6, p. 79.

Migues, R., 1968, Petrology of rodingites in ultramafites, Klamath Mountains, California: Canadian Mineralogist, v. 9, pt. 4, p. 576.

Milby, B.J., 1990, A reconnaissance fluid inclusion study of oceanic crustal rocks from the Josephine ophiolite, California-Oregon: Atlanta, Georgia State university, M.Sc. thesis, 97 p.

Miller, A.K., Furnish, W.M., Jr., and Clark, D.L., 1957, Permian ammonoids from western United States: Journal of Paleontology, v. 31, no. 6, p. 1057-1068.

Miller, C.F., 1978, An early Mesozoic alkalic magma belt in western North America, in Mesozoic paleogeography of the western United States, Howell, D.G., and McDougall, K.A., eds.: Society of Economic Paleontologists and Mineralogists, Pacific Section, Pacific Coast Paleogeography Symposium 2, p. 163-173.

Miller, D.E., 1994, Syn-magmatic extension in an Early Jurassic(?) arc volcanoplutonic complex and implications for tectonic evolution of the central Klamath Mountains, CA.: Geololgical Society of America, Abstracts with Programs, v. 26, no. 2, p. 74.

Miller, D.E., and Hacker, B.R., 1993, Detailed structure and stratigraphy of the eastern Marble Mountain terrane, Klamath Mountains, CA: Geological Society of America, Abstracts with Programs, v. 25, no. 5, p. 121

Miller, D.M., Nilsen, T. H., and Bilodeau, W.L., 1992, Late Cretaceous to early Eocene geologic evolution of the U.S. Cordillera, in Burchfiel, B.C., Lipman, P.W., and Zoback, M.L., eds., The Geology of North America Volume G-3, The Cordilleran Orogen: Conterminous U.S.: Geological Society of America, Boulder, Colorado, p. 205-260.

Miller, E.L., Miller, M.M., Stevens, C.H., Wright, J.E., and Madrid, R.J., 1992, Late Paleozoic paleogeographic and tectonic evolution of the western U.S. Cordillera, in Burchfiel, B.C., Lipman, P.W., and Zoback, M.L., eds., The Geology of North America Volume G-3, The Cordilleran Orogen: Conterminous U.S.: Geological Society of America, Boulder, Colorado, p. 57-106.

Miller, M.M., 1983, Upper Paleozoic stratigraphy and structure in the eastern Klamath belt, northern California: Geological Society of America, Abstracts with Programs, v. 15, no. 5, p. 426.

---1985, Comparison of upper Paleozoic stratigraphy in tectonostratigraphic terranes of the McCloud fusulinid belt: Geological Society of America, Abstracts with Programs, v. 17, no. 6, p. 370.

---1986, Tectonic evolution of late Paleozoic island arc sequences in the western U. S. cordillera; with detailed studies from the eastern Klamath Mountains, northern California: Stanford University, Ph.D. dissertation, 201 p.

---1987, Stratigraphic record of an island arc, eastern Klamath Mountains, northern California:

Geological Society of America Abstracts with Programs, v. 19, no. 6, p. 433.

---1987, Dispersed remnants of a northeast Pacific fringing arc; upper Paleozoic terranes of Permian 
McCloud faunal affinity, western United States: Tectonics, v. 6, no. 6, p. 807-830.

---1988, Permo-Triassic deformation within the Eastern Klamath terrane, northern California: Geological Society of America, Abstracts with Programs, v. 20, no. 3, p. 216.

---1989, Intra-arc sedimentation and tectonism: Late Paleozoic evolution of the eastern Klamath terrane, California: Geological Society of America Bull., v. 101, p. 170-187.

---1989, Stratigraphy and structure of an ancient island arc: Late Paleozoic and early Mesozoic evolution of the Eastern Klamath terrane, near McCloud Lake, northern California, in Tectonic evolution of northern California: 28th International Geological Congress, Field Trip Guidebook T108, Sausalito to Yosemite National Park, California, June 28-July 7, 1989, p. 33-45.

---1990, Episodic compressional tectonism in an intra-arc setting, Eastern Klamath terrane, northern California, in Wiley, T. J., Howell, D.G., and Wong, F.L., eds., Terrane analysis of China and the Pacific rim: Houston, Texas, Circum-Pacific Council for Energy and Mineral Resources, Earth Science Series, v. 13, p. 133-146.

Miller, M.M., and Cui, B., 1989, Submarine fan characteristics and dual sediment provences, lower Carboniferous Bragdon Formation, eastern Klamath terrane, California: Canadian Journal of Earth Science, v. 26, no. 5, p. 927-940.

Miller, M.M., and Harwood, D.S., 1989, Paleozoic and early Mesozoic paleogeographic relations between the Klamath Mountains, northern Sierra Nevada, and western North America (Penrose Conference Report): Geology, v. 17, no. 4, p. 369-372.

---1989, Mid-Paleozoic to mid-Mesozoic basinal arc successions: Comparison of the Eastern Klamath and northern Sierra Buttes terranes, California: Geological Society of America, Abstracts with Programs, v. 21, no. 5, p. 117-118.

---1990, Paleogeographic setting of upper Paleozoic rocks in the northern Sierra and eastern Klamath terranes, northern California, in Harwood, D.S., and Miller, M.M., eds., Paleozoic and early Mesozoic paleogeographic relations; Sierra Nevada, Klamath Mountains, and related terranes; Geological Society of America Special Paper 255, p. 175-192.

Miller, M. M., and Saleeby, J. B., 1987, Detrital zircon studies of the Galice Formation: Common provenance of strata overlying the Josephine ophiolite and Rogue island arc--W Klamath Mtns terrane: Geological Society of America, Abstracts with Programs, v. 19, no. 7, p. 772-773.

---1989, Proterzoic detrital zircon from the Carboniferous Bragdon Formation, E. Klamath terrane, California; continent-influenced arc sedimentation: Geological Society of America Abstracts with Programs, v. 21, no. 26, p. 347.

---1989, Accretionary tectonics: Examples from the North American Cordillera, in James, D.E., ed., Encyclopedia of Solid Earth Geophysics: Van Nostrand Reinhold Company Inc., p. 9-20.

---1991, Continental detrital zircon in Carboniferous ensimatic arc rocks, Bragdon Formation, eastern Klamath terrane, northern California: Geological Society of America Bulletin, v. 103, no. 2, p. 268-276.

---1991, Permian and Triassic paleogeography of the eastern Klamath arc and eastern Hayfork subduction complex, Klamath Mountains, California, in Cooper, J.D. and Stevens, C.H., eds., Paleozoic Paleogeography of the Western United States II: Society of Economic Paleontologists and Mineralogists, Pacific Section, v. 67, p. 643-652.

---1991, 2.1 Ga detrital zircon from Tethyan belt melange, E. Hayfork terrane, California: Continentsourced sand in an oceanic subduction complex: Geological Society of America, Abstracts with Programs, v. 23, no. 5, p. 481.

---1994, U-Pb geochemistry of detrital zircon from the Upper Jurassic Galice Formation and related rocks, western Klamath Mountains: Correlation and Klamath Mountains provenance: Eos (American Geophysical Union Trans.), v. 75, no. 44, p. 686.

Miller, M.M., Saleeby, J.B., and Cui, B., 1988, Provenance of the Carboniferous Bragdon Formation, eastern Klamath terrane, California: Proterozoic detrital zircon and quartzose detritus as continental tracers in oceanic margin systems: Fourth International Circum-Pacific Terranes. Conference, Nanjing, Peoples Republic of China, Proceedings.

Miller, M.M., and Wright, J.E., 1985, New biogeographic implications of a Permian Tethyan coral, Klamath Mountains, California: Geological Society of America, Abstracts with Programs, v. 17, no. 7, p. 664-665.

---1987, Paleogeographic implications of Permian Tethyan corals from the Klamath Mountains, California: Geology, v. 15, p. 266-269.

Miller, W.P., 1890, Trinity County in 10th Report of the State Mineralogist: California State Mining 
Bureau, p. 695-727.

Monger, J.W.H., 1973, Correlation of pre-Tertiary geology between Canadian and United States' segments of the Cordillera: Geological Society of America, Abstracts with Programs, v. 5, no. 1, p. 82-83.

---1975, Correlation of engeosynclinal tectono-stratigraphic belts in the North American cordillera: Geoscience Canada, v. 2, no. 1, p. 4-10.

---1977, Upper Paleozoic rocks of western Cordillera and their bearing on Cordilleran evolution: Canadian Journal of Earth Sciences, v. 14, p. 1832-1859.

Montoya, J.W., and Baur, G.S., 1963, Nickeliferous serpentines, chlorites, and related minerals found in two lateritic ores: American Mineralogist, v. 48, nos. 11-12, p. 1227-1238.

Moore, G.W., and Silver, E.A., 1968, Gold distribution on the sea floor off the Klamath Mountains, California: U.S. Geological Survey Professional Paper 600-C, p. C144-C148.

Moore, G.W., and Stephens, J.G., 1954, Reconnaissance for uranium-bearing carbonaceous rocks in California and adjacent parts of Oregon and Nevada: U.S. Geological Survey Circular 313, 8 p.

Mooring, C.E., 1978, Petrogenesis of the Russian Peak ultramafic complex, northern California: Madison, University of Wisconsin, M.S. thesis, 230 p.

Moring, B., 1983, Reconnaissance surficial geologic map of the Medford $1^{\circ}$ by 2 quadrangle, Oregon-California: U.S. Geological Survey Miscellaneous Field Studies Map MF-1528, scale $1: 125,000$.

Mortimer, N., 1983, Stratigraphy and volcanic geochemistry of a Permian to mid-Jurassic marginal basin assemblage near Yreka, Klamath Mountains, California: Geological Society of America, Abstracts with Programs, v. 15, no. 5, p. 314.

---1984, Deformation, metamorphism and terrane amalgamation, NE Klamath Mountains, California, in Howell, D. G., and others, eds., Proceedings of the circum-Pacific terrane conference, 1983: Stanford University Publications in the Geological Sciences, v. 18, p. 155-157.

---1984, Petrology and structure of Permian to Jurassic rocks near Yreka, Klamath Mountains, California: Stanford, Stanford University, Ph.D. dissertation, 84 p.

---1984, Geology of the Klamath Mountains near Yreka, California, in Nilsen, T. H., ed., Geology of the Upper Cretaceous Hornbrook Formation, Oregon and California: Society of Economic Paleontologists and Mineralogists, Pacific Section, v. 42, p. 167-178.

---1985, Constraints on the Permian to Jurassic evolution of the Klamath Mountains: Geological Society of America, Abstracts with Programs, v. 17, no. 6, p. 371-372.

---1985, Structural and metamorphic aspects of Middle Jurassic terrane juxtaposition, northeastern Klamath Mountains, California, in D. G. Howell, ed., Tectonostratigraphic terranes of the circumPacific region: Circumpacific Council for Energy and Mineral Resources, Earth Science Series no. 1, p. 201-214.

---1986, Late Triassic, arc-related, potassic igneous rocks in the North American cordillera: Geology, v. 14 , no. 12, p. 1035-1038.

Mortimer, N., and Coleman, R.G., 1984, A Neogene structural dome in the Klamath Mountains, California and Oregon, in Nilsen, T. H., ed, Geology of the Upper Cretaceous Hornbrook Formation, Oregon and California: Society of Economic Paleontologists and Mineralogists, Pacific Section, v. 42, p. 179-186.

---1985, A Neogene structural dome in the Klamath Mountains, California and Oregon: Geology, v. 13, no. 4, p. 253-256.

Muller, E.R., Metcalf, R.V., and Wallin, E.T., 1999, Ultradepleted supra-subduction zone magmatism of the Devonian Porcupine Lake mafic intrusive complex, Trinity terrane, California: Geological Society of America, Abstracts with Programs, v. 31, no. 6, p. 81.

Murchey, B., 1985, Using radiolarian assemblage variations as a tool for paleogeographic reconstructions: Eos (American Geophysical Union Trans.), v. 66, no. 46, p. 862.

Murchey, B.L. and Blake, M.C., Jr., 1993, Evidence for subduction of a major ocean plate along the California margin during the Middle to Early Jurassic, in Dunne, G., and McDougall, K., eds., Mesozoic Paleogeography of the Western United States - II: Society of Economic Paleontologists and Mineralogists, Pacific Section, Book 71, p. 1-18.

Murchey, B.L., and Jones, D.L., 1994, The environmental and tectonic significance of two coeval Permian radiolarian-sponge associations in eastern Oregon, in T.L. Vallier and H.C. Brooks, eds., Geology of the Blue Mountains region of Oregon, Idaho, and Washington: U.S. Geological Survey Professional Paper 1439, p. 183-198. 
Murchey, B.L., Jones, D.L., and Blome, C.D., 1983, Comparison of Permian and lower Mesozoic radiolarian chert in western accreted terranes: Geological Society of America, Abstracts with Programs, v. 15, no. 5, p. 371.

Murchey, B., Jones, D.L., and Holdsworth, B.K., 1983, Distribution, age, and depositional environments of radiolarian chert in western North America, in Siliceous deposits in the Pacific region, Iijima, A., Hein, J.R., and Siever, R., eds.: Elsevier Scientific Publishing Company, Developments in sedimentology 36, p. 109-125.

Murphy, K., 1994, No Name caves in southwestern Oregon are now under BLM care: Oregon Geology, v. 56, no. 5, p. 108-110.

Murphy, M.A., Rodda, P.U., and Morton, D.M., 1969, Geology of the Ono quadrangle, Shasta and Tehama Counties, California: California Division of Mines and Geology Bulletin 192, 28 p.

Murray, M., and Condie, K.C., 1971, Paleozoic and pre-Cretaceous Mesozoic history of the eastern Klamath province, northern California: Geological Society of America, Program, Annual Meeting, v. 3, no. 7, Washington, D. C., p. 655.

---1973, Post-Ordovician to Early Mesozoic history of the eastern Klamath subprovince, northern California: Journal of Sedimentary Petrology, v. 43, no. 2, p. 505-515.

Nachman, D.A., 1976, Geology of the Duzel Rock area, Yreka quadrangle, California: Corvallis, Oregon State University, M.S. thesis, 153 p.

Nelson, J.S., 1960, Serpentine delineation in North Coastal and other areas by mapping associated magnetic anomalies: California Association of Engineering Geologists, 3rd Annual Meeting, Berkeley, October 14-16, p. 11-12.

Nelson, S.E., 1986, The geoology and mineralization potential of the Bella Vista-Ingot area, Shasta County, California: Tempe, Arizona University, M. Sc. thesis.

Nestell, M.K., 1991, The Upper Fusulinids Reichelina and Parareichelina in northern California: Evidence for long-distance tectonic transport, in Cooper, J.D., and Stevens, C.H. eds. Paleozoic Paleogeography of the western United States II, vol 1 and 2: Society of Economic Paleontologists and Mineralogists, Pacific Section, v. 67, p. 635-642.

Nestell, M.K., Irwin, W.P., and Albers, J.P., 1981, Late Permian (Early Djulfian) Tethyan Foraminifera from the southern Klamath Mountains, California: Geological Society of America, Abstracts with Programs, v. 13, no. 7, p. 519.

Newberry, J.S., 1857, Report on the Geology of the route, in Reports of explorations and surveys, to ascertain the most practical and economical routes for a railroad from the Mississippi River to the Pacific Ocean: U.S. War Department, v. 6, Part 2, p. 5-68.

Newberry, J.S., 1874, On the occurrence of chromic iron and serpentine in California: Lyceum Natural History, New York, Proceedings (2), no. 3, p. 66.

Newkirk, S.R., 1977, Petrology of the Ono metaperidotite, south central Klamath Mountains, California: Dallas, Texas, Southern Methodist University, M.Sc. thesis.

Newkirk, S.R., 1977, Petrology of the Ono metaperidotite, southeastern Klamath Mountains, northern California: Geological Society of America, Abstracts with Programs, v. 9, no. 4, p. 473-474.

Niazi, M., 1964, Seismicity in northern California and western Nevada: Seismological Society of America Bulletin, v. 54, no. 2, p. 845-850.

Nickell, F.A., 1942, Development and use of engineering geology: American Association of Petroleum Geologists Bulletin, v. 26, no. 12, p. 1797-1826; also abstract, no. 5, p. 903, May, 1942.

Nilsen, T.H., 1984, Tectonics and sedimentation of the Upper Cretaceous Hornbrook Formation, Oregon and California, in Crouch, J.k., and Bachman, S.B., eds., Tectonics and sedimentation along the California Margin: Society of Economic Paleontologists and Mineralogists, Pacific Section, Field Trip Guidebook, v. 38, p. 101-117.

---1984, Stratigraphy, sedimentology, and tectonic framework of the Upper Cretaceous Hornbrook Formation, Oregon and California, in Nilsen, T.H., ed., Geology of the Upper Cretaceous Hornbrook Formation, Oregon and California: Society of Economic Paleontologists and Mineralogists, Pacific Section, v. 42, p. 51-88.

---1993, Stratigraphy of the Cretaceous Hornbrook Formation, southern Oregon and northern California: U.S. Geological Survey Professional Paper 1521, 89 p., with map, scale 1:62,500.

Nilsen, T.H., Barats, G.M., Elliot, M.A., and Jones, D.L., 1983, Geologic map of the outcrop area of the Hornbrook Formation, Oregon and California: U. S. Geological Survey Open-file Report 83-373, scale 1:62,500:, p. 
Nishimori, R.K., Hawkins, J.W., and Fujita, H., 1972, Mafic and ultramafic layered rocks of the ocean floor and orogenic belts: Geological Society of America, Abstracts with Progams, v. 4, no. 3, p. 209-210.

Noble, P., and Renne, P., 1990, Paleoenvironmental and biostratigraphic significance of siliceous microfossils of the Permo-Triassic Redding section, eastern Klamath Mountains, California: Marine Micropaleontology, v. 15, p. 379-391.

Noller, J.S., 1984, The role of primary upper mantle magmas in the generation of chromite schlieren and compositional layers in the Trinity peridotite, Klamath Mountains, California: Los Angeles, California State University, M. Sc. thesis.

Noller, J.S., and Carter, B., 1985, The origins of dunite and chromite schlieren in the Trinity peridotite, Klamath Mountains, California: Geological Society of America, Abstracts with Programs, v. 17, no. 6, p. 397.

Nordstrom, D.K., Alpers, C.N., and Ball, J.W., 1991, Measurement of negative $\mathrm{pH}$ values and high metal concentrations in extremely acidic mine waters from Iron Mountain, California: Geological Society of America, Abstracts with Programs, v. 23, no. 5, p. 383.

Norman, E.A.S., 1984, The structure and petrology of the Summit Valley area, Klamath Mountains, California: Salt Lake City, University of Utah, M.S. thesis, 247 p.

Norman, E.A., Gorman, C.M., Harper, G.D., and Wagner, D., 1983, Northern extension of the Rattlesnake Creek terrane: Geological Society of America, Abstracts with Programs, v. 15, no. 5, p. 314-315.

Norrell, G.T., 1989, Structural geology of the Josephine peridotite, northern California: Implications for structural processes at slow spreading centers: Albany, New York State University, Ph. D. dissertation.

Norrell, G.T., Alexander, R.J., and Harper, G.D., 1989, Planar and composite planar fabrics in ultramafic and mafic cataclastic rocks from the Josephine Ophiolite, NW California: Eos (American Geophysical Union Trans.), v. 70, no. 15, p. 462-463.

Norrell, G.T., and Harper, G.D., 1988, Detachment faulting and amagmatic extension at mid-ocean ridges: The Josephine ophiolite as an example: Geology, v. 16, no. 9, p. 827-830.

---1990, Ultramafic fault rocks and oceanic detachment faulting in the Josephine ophiolite, in Malpas, J., and others, eds., Ophiolites Oceanic Crustal Analogues: Nicosia, Cyprus, Geological Survey Department, Proceedings of the Symposium “Troodos 1987", p. 521-534.

Norrell, G.T., Harper, G.D., and Smith, B., 1987, Oceanic faults and serpentinitie mylonites in the Josephine ophiolite [abs.]: EOS (American Geophysical Union Transactions), v. 68, p. 425.

Norrell, G.T., Teixell, A., and Harper, G.D., 1989, Microstructure of serpentinite mylonites from the Josephine ophiolite and serpentinization in retrogressive shear zones, California: Geological Society of America, v. 101, no. 5, p. 673-682.

Norris, 1983, Metamorphism at the base of the Trinity peridotite, Coffee Creek and southern Trinity Alps areas, Klamath Mountains, northern California: Los Angeles, University of California, M.Sc. thesis, $109 \mathrm{p}$.

Norris, R.M., and Webb, R.W., 1990, Klamath Mountains, Chapter 4, in Geology of California: John Wiley \& Sons, Inc., Second Edition, p. 126-151.

Noto, R.C., 1999, Structure and stratigraphy of the Antelope Mountain Quartzite, California: University of Nevada, Las Vegas, thesis

Noto, R.C., and Wallin. E.T., 1998, Cretaceous inter-arc extension in the Yreka terrane, California: Geological Society of America, Abstracts with Programs, v. 30, no. 5, p. 56.

O'Brien, C.J., 1903, Geology of the district west of Redding, California: Mining and Science Press, v. 86, p. 349.

O'Brien, J.C., 1943, Clerbus-Mae tungsten prospect, Trinity County: California Journal of Mines and Geology, v. 39, no. 2, p. 142.

---1943, Current notes on activity in the strategic minerals, Redding field district: California Journal of Mines and Geology, v. 39, p. 77-84, 323-330.

---1947, Mines and mineral resources of Siskiyou County: California Journal of Mines and Geology, v. 43, p. 413-462.

---1949, The counties of California--Trinity County: California Division of Mines Bulletin 142, p. 133-135.

---1952, Mines and mineral resources of Del Norte County, California: California Journal of Mines and Geology, v. 48, p. 261-309. 
---1965, Mines and mineral resources of Trinity County, California: California Division of Mines and Geology, County Report 4, 125 p.

Oesterling, W.A., Pruss, D.E., and Laird, R.T., 1958, Areal geology of part of the southern Klamath Mountains, Shasta and Trinity Counties, California: Geological Society of America, v. 69, no. 12, pt. 2, p. 1699.

O'Farrell, C., 1933, Microscopic explanation of chromite ore from Klamath River district, California: Utah Academy of Science Arts and Letters Proceedings, v. 10, p. 69.

Ohlin, H.N., 1988, The "terrane" to gold; correlation of western Klamath Mountains and Sierra Nevada terranes, in R. W. Schafer and others, eds., Bulk mineable precious metals deposits of the western United States: Geological Society of Nevada, Symposium Proceedings, April 6-8, 1987, p. 751.

Ohr, M., 1987, Geology, geochemistry, and geochronology of the Lems Ridge olistostrome. Klamath Mountains, California: Albany, State University of New York, M.Sc. thesis, 278 p.

Ohr, M., Harper, G.D., and Wright, J.E., 1986, Fracture zone origin of the Lems Ridge olistostrome, NW California, Klamath Mountains: Eos (American Geophysical Union Trans.), v. 67, no. 44, p. 1210.

Okulitch, A.V., Richards, B.C., and Orchard, M.J., 1989, Paleozoic-early Mesozoic paleogeography of southeastern British Columbia: Similarities to the Klamath Mountains region: Geological Society of America, Abstracts with Programs, v. 21, no. 5, p. 125.

Oliver, W.A., Jr., 1964, New occurrences of the rugose coral Rhizophyllum in North America, in Geological Survey Research 1963: U.S. Geological Survey Professional Paper 475-D, p. D149-D158.

---1975, Age of Corals from northern California: Journal of Paleontology, v. 49, no. 2, p. 424.

Olmsted, F.H., 1956, Summary of ground-water conditions in northwestern California, in Water resources, Application of natural resources of northwestern California, preliminary report: U.S. Department Interior Pacific Southwest Field Commission, 93 p.

Olson, G.A., 1977, Possible Ordovician-Silurian regional metamorphic event and Early Devonian intrusive activity in the Klamath Mountains, northern California: Geological Society of America, Abstracts with Programs, v. 9, no. 4, p. 478-479.

---1978, Geology of the Grouse Creek area, China Mountain quadrangle, California: Corvallis, Oregon State University, M.S. thesis, 129 p.

Oregon Department of Geology and Mineral Industries, 1943, Oregon metal mines handbook--Jackson County: Oregon Department Geology and Mineral Industries Bulletin, no. 14-C, v. 2, sec. 2, 208 p.

---195l, State of Oregon map showing principal mineral deposits; Key to Oregon mineral deposits map, by R.S. Mason, Oregon Department Geology and Mineral Industries Miscellaneous Paper, no. 2, 15 p.

---1952, Oregon metal mines handbook--Josephine County, 2nd ed.: Oregon Department Geology and Mineral Industries Bulletin, no. 14-C, v. 2, section 1, 238 p.

---1953, The Nickel Mountain project: Ore Bin, v. 15, no. 10, p. 59-65.

---1954, Oregon's gold placers: Oregon Department Geology and Mineral Industries Miscellaneous Paper, no. 5, 14 p.

---1958, State of Oregon, Map showing principal mineral deposits: Oregon State Department of Geology and Mineral Industries, scale approximately 1 in. to $16 \mathrm{mi}$.

---1970, Nickel-bearing stream sediments from southwestern Oregon: Ore Bin, v. 32, no. 12 , p. 221-230.

O'Shaughnessy, M.M., 1899, The copper resources of California, in California mines and minerals: California Miner's Association, Souvenir edition, Louis Roesch Company, San Francisco, California, p. 205-218.

Packard, G.A., 1909, Copper mines and smelteries of Shasta County, California: Engineering and Mining Journal, v. 88, p. 393-399.

Page, N.J., Blair, W.N., Gray, F., Cannon, J.K., Grimes, D.J., and Leinz, R.W., 1977, Prelininary reconnaissance geologic map of the Wimer quadrangle, Oregon: U. S. Geological Survey Miscellaneous Field Studies Map MF-848, scale 1:62,500.

Page, N.J., Blakely, R.J., and Cannon, J.K., 1983, Map showing geological, geophysical, and geochemical characteristics of granitic plutons, Medford $1^{\circ} \times 2^{\circ}$ quadrangle, Oregon: U.S. Geological Survey Miscellaneous Field Studies Map MF-1383-E, scale 1:250,000

Page, N.J., Carlson, R.R., Miller, M.S., Gray, F., and Carlson, C.A., 1985, Map showing geochemical characteristics of platinum-group elements and gold in rock samples from the Kalmiopsis Wilderness, southwestern Oregon: U. S. Geological Survey Miscellaneous Field Studies Map 
MF-1240-F, scale 1:62,500.

Page, N.J., Gray, F., Cannon, J.K., Foose, M.P., Lipin, B., Moring, B.C., Nicholson, S.W., Sawlan, M.G., Till, A., and Ziemianski, W.P., 1981, Geologic map of the Kalmiopsis Wilderness area, Oregon:

U.S. Geological survey Miscellaneous Field Studies Map MF-1240-A, scale 1:62,500.

Page, N.J., and Johnson, M.G., 1977, Chromite resources of the podiform chromite deposits and exploration for concealed chromite deposits in the Medford-Coos Bay quadrangles, southwestern Oregon: U. S. Geological Survey Open-File Report 77-656, 14 p.

Page, N.J., Johnson, M.G., Haffty, J., and Ramp, L., 1975, Occurrence of platinum group metals in ultramafic rocks of the Medford-Coos Bay $2^{\circ}$ quadrangle, southwestern Oregon: U.S. Geological Survey Field Studies Map MF-694, scale 1:250,000.

Page, N.J., Johnson, M.G., Moring, B., Gray, F., and Cannon, J.K., 1978, Preliminary reconnaissance geologic map of the Glendale quadrangle, Oregon: U.S. Geological Survey Open-File Report OF-78-518, scale 1:62,500.

Page, N.J., Johnson, M.G., and Peterson, J.A., 1983, Map showing characteristics of lode gold in the Medford $1^{\circ}$ by $2^{\circ}$ quadrangle, Oregon-California: U.S. Geological Survey, Miscellaneous Field Studies Map MF-1383-D, 2 sheets, scale 1:250,000.

Page, N.J., and Miller, M.S., 1983, Kalmiopsis Wilderness, Oregon, in Marsh, S.P., Kropschot, S.J., and Dickinson, R.G., eds., Wilderness mineral potential: Assessment of mineral-resource potential in U. S. Forest Service lands studied 1964-1984: U.S. Geological Survey Prof. Paper 1300,p. 882-884.

Page, N.J., Miller, M.S., Grimes, D.J., Leinz, R.W., Blakely, R.J., Lipin, B.R., Foose, M.P., and Gray, F., 1982, Mineral resource potential map of the Kalmiopsis Wilderness, southwestern Oregon, with text by N. J. Page and M. S. Miller: U.S. Geological Survey Miscellaneous Field Studies Map MF-1240-E, scale 1:62,500.

Page, N.J., Moring, B., Gray, F., Cannon, J., and Blair, W.N., 1981, Reconnaissance geologic map of the Selma quadrangle, Josephine County, Oregon: U.S. Geological Survey Miscellaneous Field Studies Map MF-1349, scale 1:62,500.

Page, N.J., Singer, D.A., Moring, B.C., Carlson, C.A., McDade, J.M., Wilson, S.A., 1986, Platinum-group element resources in podiform chromitites from California and Oregon in L.J. Cabri, ed., A third issue devoted to platinum deposits: Economic Geology, v. 81, no. 5, p. 1261-1271.

Pardee, J.T., 1933, Placer deposits of the western United States in Ore deposits of the western states: American Institute of Mining and Metallurgical Engineering, New York, Lindgren Volume, p. 419-450.

Park-Jones, R., 1988, Tectonic setting and deformation of the type Galice Formation, western Klamath Mountains: Geological Society of America, Abstracts with Programs, v. 20, no. 3, p. 219-220.

---1988, Sedimentology, structure, and geochemistry of the Galice Formation; sediment fill of a back-arc basin and island arc in the western Klamath Mountains: Albany, State University of New York, M.Sc. thesis, 166 pp.

Parsons, R.B., 1978, Soil-geomorphology relations in mountains of Oregon, U.S.A.: Geoderma v. 21, no. 1, p. 25-39.

Paulsen, S.G., 1987, Contributions of sediment dentrification to the nitrogen cycle in Castle Lake, California: Davis, California University, Ph.D. dissertation.

Pavlis, T.L., 1997, The Jurassic history of the Klamath Mountains province: A product of ridge subduction?: Geological Society of America, Abstracts with Programs, v. 29, no. 5, p. 56.

Peacock, S.M., 1984, Serpentinization history of the Trinity Peridotite, Klamath Mountains, northern California: Implications for the effect of fluids in subduction zones: Eos (American Geophysical Union Trans.), v. 65, no. 45, p. 1147.

---1985, Thermal and fluid evolution of the Trinity thrust system, Klamath province, northern California: Inplications for the effects of fluids in subduction zones: Los Angeles, University of California, Ph.D. dissertation, 327 p.

---1985, Inverted metamorphic gradient and fluid evolution of the central metamorphic belt, Klamath province, northern California: Geological Society of America, Abstracts with Programs, v. 17, no. 6, p. 400.

---1987, Serpentinization and infiltration metasomatism in the Trinity peridotite, Klamath province, northern California: implication for subduction zones: Contributions to Mineralogy and Petrology, v. 95 , p. 55-70.

---1987, Creation and preservation of subduction related inverted metamorphic gradients: Journal of Geophysical Research, v. 92, no. 12, p. 12763-12781. 
---1988, Inverted metamorphic gradients in the westernmost Cordillera, in Ernst, W.G., Metamorphism and crustal evolution of the western United States: Ruby Volume 7, Pre4ntice-Hall, Englewood Cliffs, NJ, p. 954-975.

Peacock, S.M., and Hacker, B.R., 1989, Correlation of the Central Metamorphic belt, Klamath Mountains with the Feather River terrane, Sierra Nevada: Geological Society of America, Abstracts with Programs, v. 21, no. 5, p. 128-129.

Peacock, S.M., and Norris, P.J., 1988, Metamorphic evolution of the Central Metamorphic belt, Klamath province, CA: An inverted metamorphic gradient beneath the Trinity Peridotite: Journal of Metamorphic Geology, v. 7, p. 191-209.

Peck, D.L., Imlay, R.W., and Popenoe, W.P., 1956, Upper Cretaceous rocks of parts of southwestern Oregon and northern California: American Association of Petroleum Geologists Bulletin, v. 40, no. 8, p. $1968-1984$.

Pecora, W.T., and Hobbs, S.W., 1942, Nickel deposit near Riddle, Douglas County, Oregon: U.S. Geological Survey Bulletin 931-I, p. 205-226; also abstract in Economic Geology, v. 36, no. 8, p. 841, Dec. 1941.

Pecora, W.T., Hobbs, S.W., and Murata, K.J., 1949, Variations in garnierite from the nickel deposits near Riddle, Oregon: Economic Geology, v. 44, no. 1, p. 13-23.

Perttu, R.K., and Benson, G.T., 1980, The Canyonville Fault; north boundary of the Klamath Mountains: Oregon Academy of Science Proceedings, v. 16, p. 18.

Pessagno, E.A., Jr., and Blome, C.D., 1988, Biostratigraphic, chronostratigraphic, and U/Pb geochronometric data from the Rogue and Galice Formations, Western Klamath terrane (Oregon and California): Their bearing on the age of the Oxfordian-Kimmeridgian boundary and the Mirifusus first occurrence event: Proceedings of the 2nd International Synmposium on Jurassic straqtigraphy, I.U.G.S., Lisbon, Portugal, p. 14.

---1990, Implications of new Jurassic stratigraphic, geochronometric, and paleolatitudinal data from the western Klamath terrane (Smith River and Rogue Valley subterranes): Geology, v. 18, no. 7, p. 665-668.

Pessagno, E.A., Jr, Blome, C.D., Hull, D.M., and Six, W.M., 1993, Jurassic Radiolaria from the Josephine ophiolite and overlying strata, Smith River subterrane (Klamath Mountains), northwestern California and southwestern Oregon: Micropaleontology, v. 39, no. 2, p. 93-166.

Pessagno, E.A., Jr., Six, W. M., and Qun Yang, 1989, The Xiphostylidae Haeckel and Parvivaccidae, n. fam., (Radiolaria) from the North American Jurassic: Micropaleontology, v. 35, no. 3, p. 193-255.

Peters, T.J., 1983, Mineral investigation of the Weaver Bally RARE II Area (no. 5804), Trinity County, California: U. S. Bureau of Mines, Report No. MLA 9383, 22 p., map scale 1:63,360.

Petersen, S.W., 1982, Geology and petrology around Titus Ridge, north-central Klamath Mountains, California: Eugene, University of Oregon, M.Sc. thesis, 73 p.

---1982, Structural and tectonic significance around the Orleans fault near Happy Camp, north-central Klamath Mountains, California, in Evett, J.F., ed., Proceedings of the Oregon Academy of Science, fortieth annual meeting: Oregon Acadeny of Science, Proceedings, v. 18.

---1987, The Billy's Peak mafic dike complex in the Trinity sheet, Klamath Mountains, California: Geological Society of America Abstracts with Programs, v. 19, no. 6, p. 439.

---1993, Geology and geochemistry of the Craggy Peak pluton, Deadman Peak pluton, and the Billy's Peak mafic complex, Klamath Mountains, California: Lubbock, Texas Tech University, 157 p.

Petersen, S.W., and Barnes, C.G., 1986, Magma mingling and compositional variation in the Craggy Creek pluton, south-central Klamath Mountains, California: Geological Society of America, Abstracts with Programs, v. 18, no. 2, p. 170-171.

Petersen, S.W., Barnes, C.G., and Hoover, J.D., 1991, The Billy's Peak mafic complex of the Trinity sheet, California: Roots of a Paleozoic island arc, in Cooper, J.D. and Stevens, C.H., eds., Paleozoic Paleogeography of the Western United States II: Society of Economic Paleontologists and Mineralogists, Pacific Section, v. 67, p. 625-633.

Petersen, S.W., Barnes, C.G., Kistler, R.W., and Hoover, J.D., 1988, Geochemical comparison of pre- and post-Nevadan plutons in the Klamath Mountains, CA: Evidence for a common source: Geological Society of America, Abstracts with Programs, v. 20, n0. 3, p. 221.

Peterson, J.A., 1980, Metallogenetic maps of ophiolites in the western United States, in Augustithis, S. S., ed., An international symposium on metallogeny of mafic and ultramafic complexes; the eastern Mediterranean-western Asia area, and its comparison with similar metallogenic environments in the world.: UNESCO National Technical University, Department of Mineralology- 
Petrography-Geology, p. 90-91.

---1984, Metallogenetic maps of the ophiolite belts of the western United States: U.S. Geological Survey, Miscellaneous Investigations Series I-1505, scale 1:2,500,000, with text $16 \mathrm{p}$.

Peterson, J.A., and Caress, M.E., 1983, Geochemical map of the Mount Eddy and Castle Crags Roadless Areas, Shasta, Siskiyou, and Trinity Counties, California: U.S. Geological Survey, Miscellaneous Field Studies Map MF-1529-A, scale 1:62,500.

Peterson, J.A., and Denton, D.K., Jr., 1984, Mount Eddy and Castle Crags Roadless Area, California, in Wilderness Mineral Potential, S. P. Marsh and others, eds.: U.S. Geological Survey Professional Paper 1300, v. 1, p. 303-305.

Peterson, J.A., and Gray, F., 1982, Geochemical map and rock and stream-sediment data from the Wild Rogue Wilderness, Coos and Curry Counties, Oregon: U. S. Geological Survey Miscellaneous Field Studies Map MF-1381-B, scale 1:48,000.

Peterson, J.A., Caress, M.E., and Quick, J.E., 1983, Geochemical analyses of rock and stream-sediment samples from Mount Eddy and Castle Crags Roadless Areas, Shasta, Siskiyou, and Trinity Counties, California: U. S. Geological Survey Open-File Report 83-0013, map scale 1:62500, text 17 p.

Peterson, J.A., Caress, M.E., Denton, D.K., and Spear, J.M., 1983, Mineral resource potential of the Mount Eddy and Castle Crags Roadless Areas, Shasta, Siskiyou, and Trinity Counties, California: .U.S. Geological Survey, Miscellaneous Field Studies Map MF-1529-B, scale 1:62,500, with 4 page text.

Peterson, J.A., Quick, J.E., Throckmorton, M.L., and Caress, M. E., 1983, Geologic map of the Mount Eddy and Castle Crags Roadless Areas, Shasta, Siskiyou, and Trinity Counties, California: U.S. Geological Survey, Miscellaneous Field Investigations Map MF-1529-C, scale 1:62,500.

Peterson, N.V., and Mason, R.S., 1958, Limestone occurrence in western Oregon: Ore Bin, v. 20, no. 4, p. 33-39.

Phillips, P.A., 1989, The geology of the Weaverville Formation in the vicinity of Weaverville, California: Arcata, California, Humboldt State University, M.Sc. thesis, 174 p.

Phillips, P.A., and Aalto, K.R., 1989, The Weaverville Formation: Implications for tectonically controlled basin development in the Klamath Mountains, northern California: Geological Society of America, Abstracts with Programs, v. 21, no. 5, p. 129.

---1989, The Weaverville Formation: Implications for tectonically controlled basin development in the central Klamath Mountains, in Colburn I., Abbott, P., and Minch, J, eds., Conglomerates in basin analysis: Society of Economic Paleontologists and Mineralogists, Pacific Section, vol. 62, p. 81-98.

Pinto-Auso, M., 1984, Geochemistry, petrology, and mineralogy of the pelagic/hemipelagic sequence overlying the Josephine ophiolite, Klamath Mountains, California: Salt Lake City, Utah University, M. Sc. thesis.

Pinto-Auso, M., and Harper, G.D., 1985, Sedimentation, metallogenesis, and tectonic origin of the basal Galice Formation overlying the Josephine ophiolite, northwestern California: Journal of Geology, v. 93, no. 6, p. 713-725.

Poole, F.G., Sandberg, C.A., and Boucot, A.J., 1977, Silurian and Devonian paleogeography of the western United States, in Stewart, J.H., Stevens, C.H., and Fritsche, A.E., eds, Paleozoic paleogeography of the western United States, Pacific Coast Paleogeography Symposium: Society of Economic Paleontologists and Mineralogists, Pacific Section, p. 39-66.

Poole, F.G., Stewart, J.H., Palmer, A.R., Sandberg, C.A., Madrid, R.J., Ross, R.J., Jr., Hintze, L.F., Miller, M.M., and Wrucke, C.T., 1992, Latest Precambrian to latest Devonian time: Development of a continental margin, in Burchfiel, B.C., Lipman, P.W., and Zoback, M.L., eds., The Geology of North America Volume G-3, The Cordilleran Orogen: Conterminous U.S.: Geological Society of America, Boulder, CO, p. 9-56.

Popenoe, W.P., 1937, Upper Cretaceous stratigraphy and fauna of the Redding quadrangle, northern California: Geological Society of America Proceedings 1936, p. 95.

---1938, Cretaceous stratigraphy and faunas of the Redding quadrangle, California: Geological Society of America Proceedings 1937, p. 296.

Porter, R.W., 1973, Geology of Facey Rock area, Etna quadrangle, California: Corvallis, Oregon State University, M.S. thesis, $87 \mathrm{p}$.

Potter, A.W., 1977, Inferred tectonic settings of early Paleozoic rocks south of Yreka, eastern Klamath Mountains, northern California: Geological Society of America, Abstracts with Programs, v. 9, no. 4, p. 483. 
---1977, Stratigraphy of the Moffett Creek and Gazelle Formations northeast of Gregg Ranch, eastern Klamath Mountains, northern California, in D.F.R. McGeary, ed., Guidebook to the geology of the Klamath Mountains, northern California: Geological Society of America, Cordilleran Section, 73rd Annual Meeting, Sacramento, California, Guidebook, p. 80-103.

---1982, Klamath Mountains, Northern California, in Ross, R.J., Jr., and others, eds., The Ordovician system in the United States: International Union of Geological Sciences, Publication No. 12:, p. 30-33.

---1987, Stratigraphy and selected Ordovician brachiopods from the Horseshoe Gulch and Gregg Ranch areas, eastern Klamath Mountains, northern California: Corvallis, Oregon State University, Ph.D. dissertation, 426 p.

---1990, The Ordovician brachiopod genus Bimuria from the eastern Klamath Mountains, northern California: Journal of Paleontology, v. 64, no. 2, p. 200-213.

---1990, Middle and Late Ordovician brachiopods from the eastern Klamath Mountains, northern California, Part I: Palaeontographica abt A, v. 212, p. 31-158.

---1990, Middle and Late Ordovician brachiopods from the eastern Klamath Mountains, northern California, Part II: Palaeontographica abt A, v. 213, p. 1-114.

Potter, A.W., and Boucot, A.J., 1971, Ashgillian, Late Ordovician brachiopods from the eastern Klamath Mountains of northern California: Geological Society of America, Abstracts with Programs, v. 3, no. 2, p. 180-181.

Potter, A.W., Boucot, A.J., Bergstrom, S.M., Blodgett, R.B., Dean, W.T., Flory, R.A., Ormiston, A.R., Pedder, A.E.H., Rigby, J.K., Rohr, D.M., and Savage, N.M., 1990, Early Paleozoic stratigraphic, paleogeographic, and biogeographic relations of the eastern Klamath belt, northern California, in Harwood, D.S., and Miller, M.M., eds., Paleozoic and early Mesozoic paleogeographic relations; Sierra Nevada, Klamath Mountains, and related terranes; Geological Society of America Special Paper 255, p. 57-74.

Potter, A.W., Boucot, A.J., Bergstrom, S.M., Blodgett, R.B., Dean, W.T., Flory, R.A., Ormiston, A.R., Rohr, D.M., and Savage, N.M., 1989, Ordovician to Devonian biogeography of the Eastern Klamath terrane (EKT): Geological Society of America, Abstracts with Programs, v. 21, no. 5, p. 130.

Potter, A.W., Gilbert, W.G., Ormiston, A.R., and Blodgett, R.B., 1980, Middle and Upper Ordovician brachiopods from Alaska and northern California and their paleogeographic implications: Geological Society of America, Abstracts with Programs, v. 12, no. 3, p. 147.

Potter, A.W., and Grunder, A.L., 1989, Inferred tectonic settings of Early Cambrian and Ordovician intrusive rocks, Eastern Klamath terrane (EKT), northern California: Geological Society of America, Abstracts with Programs, v. 21, no. 5, p. 130.

---1992, Geochemical relationships among early Paleozoic igneous rocks, Yreka and Trinity terranes, northern California: Geological Society of America, Abstracts with Programs, v. 24, no. 5, p. 75.

Potter, A.W., and Hotz, P.E., 1977, Inferred tectonic settings of early Paleozoic rocks south of Yreka, eastern Klamath Mountains, northern California: Geological Society of America Abstracts with Programs, v. 9, no. 4, p. 483.

Potter, A.W., Hotz, P.E., and Lanphere, M., 1981, Evidence of Ordovician-Silurian subduction and Silurian or older igneous units of possible magmatic arc origin, eastern Klamath Mountains, Northern California: Geological Society of America, Abstracts with Programs, v. 13, no. 2, p. 101.

Potter, A.W., Hotz, P.E., and Rohr, D.M., 1977, Stratigraphy and inferred tectonic framework of lower Paleozoic rocks in the eastern Klamath Mountains, northern California, in Paleozoic paleogeography of the western United States: Society of Economic Paleontologists and Mineralogists, Pacific Section, Pacific Coast Paleogeography Symposium 1, p. 421-440.

---1977, Stratigraphic relations and possible paleogeographic models of Lower Paleozoic rocks of the Eastern Klamath Mountains, California: Fifty-second annual meeting Pacific Sections American Association of Petroleum Geologists, Society of Exploration Geophysicists, and Society of Economic Paleontologists and Mineralogists, Bakersfield, Ca., Program, p. 31.

Potter, A.W., and Scheidegger, K.F., 1973, Paleozoic keratophyre and spilite from the Gazelle-Callahan area, Klamath Mountains, northern California: Geological Society of America, Abstracts with Programs, v. 5, no. 1, p. 91-92.

Potter, A.W., Scheidegger, K.F., and Corliss, J.B., 1976, Magma types of early Paleozoic altered volcanic rocks of the eastern Klamath Mountains, northern California: Further results: Eos 
(American Geophysical Union Trans.), v. 57, no. 12, p. 1023.

Potter, A.W., Scheidegger, K.F., Corliss, J.B., and Dasch, E.J., 1975, Magma types present in Paleozoic keratophyres and spilites from the Gazelle area, eastern Klamath Mountains, northern

California: Geological Society of America, Abstracts with Programs, v. 7, no. 7, p. 1231-1232.

Potter, A.W., Watkins, R., Boucot, A.J., Elias, R.J., Flory, R.A., and Rigby, J.K., 1990, Biogeography of the Upper Ordovician Montgomery Limestone, Shoo Fly Complex, northern Sierra Nevada, California, and comparisons of the Shoo Fly Complex with the Yreka terrane, in Harwood, D.S., and Miller, M.M., eds., Paleozoic and early Mesozoic paleogeographic relations; Sierra Nevada, Klamath Mountains, and related terranes; Geological Society of Ameica Special Paper 255, p. 3341.

Powers, H.A., 1926, The history and petrography of the Siskiyou batholith, Oregon: Eugene, University of Oregon, M.S. thesis, $50 \mathrm{p}$.

Pratt, W.P., 1964, Geology of the Marble Mountains area, Siskiyou County, California: Stanford, California, Stanford University, Ph.D. dissertation, 88 p; also Dissertation Abstracts v. 25, no. 7, p. 4084.

---1964, Jurassic(?) regional metamorphism in the Marble Mountains, northern California: Geological Society of America Special Paper 82, Annual Meeting, Miami, Fla., 1964, Program, p. 154.

Prescott, B., 1908, Ilvaite from Shasta County, California: American Journal of Science, v. 24 (4), p. 14-16.

---1908, The occurrence and genesis of the magnetite ores of Shasta County, California: Economic Geology, v. 3, p. 465-480.

Price, E.L., Giaramita, M.J., and Harper, G.D., 2001, Preliminary pertography and geochemistry of a newly discovered sheeted dike complex on the Elk River, southwestern Oregon: Seological Society of America, Abstracts with Programs, v. 33, no. 3, p. 47.

Pridmore, C.L., and Frost, E.G., 1992 Detachment faults, California's extended past: California Geology, p. 3-17.

Prokopovich, N.P., 1966, Spring Creek and its delta, Shasta County, California: Geological Society of America Special Paper 87, p. 224.

---1975, Calcareous deposits in Clear Creek tunnel, California: Geological Society of America, Abstracts with Programs, v. 7, no. 3, p. 362-363.

Putnam, B.J., 1974, Geology and geochemistry of mercury occurrences in the Horse Creek area, Siskiyou County, California: Los Angeles, University of California, M. S. thesis.

Quick, J.E., 1980, The structural and petrologic evolution of the Trinity peridotite, Eastern Klamath Mountains, California: Geological Society of America, Abstracts with Programs, v. 12, no. 3, p. 148.

---1981, Petrology and petrogenesis of the Trinity Peridotite, northern California: Pasadena, California Institute of Technology, Ph.D. dissertation, Part 1, 287 p.

---1981, Petrology and petrogenesis of the Trinity Peridotite, an upper mantle diapir in the eastern Klamath Mountains, northern California: Journal of Geophysical Research., v. 86, no. B12, p. 11837-11863.

---1981, The origin and significance of large, tabular dunite bodies in the Trinity peridotite, northern California: Contributions Mineralogy Petrology, v. 78, p. 413-422.

---1981, Igneous history of the Trinity Peridotite, northern California; field and petrochemical evidence for multiple depths of basalt genesis: Geological Society of America, Abstracts with Programs, v. 13, no. 7, p. 534.

Quick, J.E., and Albee, A.L., 1979, Evidence for partial melting in the Trinity Peridotite; a possible "high-temperature" peridotote in the eastern Klamath Mountains, northern California: Geological Society of America, Abstracts with Programs, v. 11, no. 3, p. 123.

---1979, Dike-wall rock interactions in the Trinity Peridotite, N. California; zone refining in the upper mantle: Geological Society of America, Abstracts with Programs, v. 11, no. 7, p 500.

Quick, J.E., Albee, A.L., and Quick, G.L., 1980, The structural and petrologic evolution of the Trinity Peridotite, eastern Klamath Mountains, California: Geological Society of America, Abstracts with Programs, v. 12, no. 3, p. 148.

Quick, J.E., Carter, B., Norris, P.J., and Quick, G.L., 1982, An upper-mantle magma chamber in the Trinity peridotite, Northern California: Geological Society of America, Abstracts with Programs, v. 14, no. 4, p. 226.

Quine, R.L., 1977, Geology of Lower Chrome Ridge, Josephine County, Oregon: Eugene, Oregon University, M. S. thesis, $105 \mathrm{p}$. 
Raines, G.L ., McGee, L.G., and Sutley, S.J., 1985, Near-infrared spectra of West Shasta gossans compared with true and false gossans from Australia and Saudi Arabia: Economic Geology, v. 80, no. 8 , p. $2230-2239$.

Ramer, A.R., 1967, Petrology of a portion of the Josephine Peridotite sheet, Josephine County, Oregon: Eugene, University of Oregon, M.S. thesis, 121 p.

Ramp, L., 1956, Structural data from the Chrome ridge area, Josephine County, Oregon: Ore Bin, v. 18, no. 3, p. 19-25.

---1957, Geology of the lower Illinois River chromite district: Ore Bin, v. 19, no. 4, p. 29-34.

---1957, Nature and origin of southwestern Oregon chromite deposits: Mining Engineering, v. 9, no. 8, p. 894-897.

---1960, Gold placer mining in southwestern Oregon: Ore Bin, v. 22, no. 8, p. 75-79.

---1960, The Quartz Mountain silica deposit, Oregon: Ore Bin, v. 22, no. 11,p. 109-114.

---1961, Chromite in southwestern Oregon: Oregon Department of Geology and Mineral Industries Bulletin 52, 169 p.

---1969, Geology of the Klamath Mountains Province, in Mineral and water resources of Oregon: U.S. 90th Congress, 2nd Session, Senate Committee of Interior and Insular Affairs, Committee Printing, p. 47-52.

---1972, Geology and mineral resources of Douglas County, Oregon: Oregon Department of Geology and Mineral Industries Bulletin, no. 75, 106 p., Illustrations (including colored Geological map, $1: 250,000)$.

---1975, Geology and mineral resources of the Upper Chetco drainage area, Oregon, including the Kalmiopsis Wilderness and Big Craggies Botanical Areas: Oregon Department of Geology and Mineral Industries, Bulletin 88, 47 p.

---1978, Investigations of nickel in Oregon: Oregon Department of Geology and Mineral Industries, Miscellaneous Paper 20, 68 p.

---1980, Sheeted dikes of the Wild Rogue Wilderness, Oregon: Oregon Geology, v. 42, no. 7, p. 119-124.

---1984, Geologic map of the southeast quarter of the Pearsoll Peak quadrangle, Curry and Josephine Counties, Oregon: Oregon Department of Geology and Mineral Industries, Geologic Map Series GMS-30, scale 1:24,000.

Ramp, L., and Brooks, H.C., 1969, Platinum group metals, in Mineral and water rescources of Oregon: U. S. 90th Congress, 2nd sess., Senate Committee Interior and Insular Affairs, Committee Print, kp. 169-171.

Ramp, L., Brooks, H.C., and Hull, D.A., 1975, Oregon's gold potential: Pacific Northwest Metallurgical Mineralogy Conference, Gold Money Session, Gold Technology Session, Paper, no. 5, p. 174-179.

Ramp, L., and Gray, F., 1980, Sheeted dikes of the Wild Rogue Wilderness, Oregon: Oregon Geology, v. 42, no. 7, pp. 119-124.

Ramp, L., and Moring, B., 1986, Reconnaissance geologic map of the Mariel quadrangle, southwestern Oregon: U. S. Geological Survey, Miscellaneous Field Studies Map MF-1735, scale 1:62,500.

Ramp, L., and Peterson, N.V., 1979, Geology and mineral resources of Josephine County, Oregon: Oregon Department of Geology and Mineral Industries, Bulletin 100, $45 \mathrm{p}$.

Ransome, A.L., and Kellogg, J.L., 1939, Quicksilver resources of California: California Journal of Mines and Geology, v. 35, p. 353-486.

Rawson, S.A., 1984, Regional metamorphism of rodingites and related rocks from the north-central Klamath Mountains, California: Eugene, University of Oregon, Ph.D. dissertation, 235 p.

Rawson, S.A., and Petersen, S.W., 1982, Structural and lithologic equivalence of the Rattlesnake Creek terrane and high-grade rocks of the western Paleozioc and Triassic belt, north central Klamath Mountains, California: Geological Society of America, Abstracts with Programs, v. 14, no. 4, p. 226.

Rawson, S.A., and Rice, J.M., 1983, Petrology of metarodingites from an ultramafic-mafic complex at Huckleberry Mountain, north-central Klamath Mountains, California: Geological Society of America, Abstracts with Programs, v. 15, no. 5, p. 436.

Reed, M.H., 1977, Calculations of hydrothermal metasomatism and ore deposition in submarine volcanic rocks with special reference to the West Shasta district, California: Berkeley, University of California, Ph.D. dissertation, $200 \mathrm{p}$.

---1984, Geology, wall-rock alteration, and massive sulfide mineralization in a portion of the West Shasta district, California: Economic Geology, v. 79, no. 6, p. 1299-1318.

Reid, J.A., 1908, The copper belt of California: Engineering and Mining Journal, v. 85, p. 420. 
Renne, P.R., 1986, Permian to Jurassic tectonic evolution of the eastern Klamath Mountains, California: Berkeley, California University, Ph.D. dissertation, 127 p.

---1988, Structural chronology, oroclinal deformation, and tectonic evolution of the southeastern Klamath Mountains, California: Tectonics, v. 7, no. 6, p. 1223-1242.

---1991, Sediment provenance and Cenozoic tectonic evolution of the centrtal and western Klamath Mountains and northernmost Coast Ranges, California: Geological Society of America Abstracts with Programs, v. 23, p. 137.

Renne, P.R., and Carmichael, I.S.E., 1984, Intra-arc ultrabasic volcanism: Permian limburgites of the eastern Klamath Mountains: Geological Society of America, Abstracts with Programs, v. 16, no. 6, p. 632.

Renne, P.R., Curtis, G.H., and Scott, G.R., 1986, Nature and timing of deformation in the Redding section, eastern Klamath Mountains, California: Geological Society of America, Abstracts with Programs, v. 18, no. 2, p. 175.

Renne, P.R., and Scott, G.R., 1986, Comment, in Comments and Reply on "Paleomagnetism of the Upper Jurassic Galice Formation, southwestern Oregon: Evidence for differential rotation of the eastern and western Klamath Mountains": Geology, v. 14, no. 12, p. 1048-1049.

---1988, Structural chronology, oroclinal deformation, and tectonic evolution of the southeastern Klamath Mountains, California: Tectonics, v. 7, no. 6, p. 1223-1242.

Renne, P.R., Scott, G.R., and Bazard, D.R., 1986, Multicomponent paleomagnetic data from the eastern Klamaths: Cratonic Permian directions with secondary Middle Jurassic overprints: Geological Society of America, Abstracts with Programs, v. 18, no. 2, p. 175.

---1988, Multicomponent paleomagnetic data from the Nosoni Formation, eastern Klamaths: Cratonic Permian primary directions with Jurassic overprints: Journal of Geophysical Research, v. 93, p. 3387-3400.

Rhoades, R.F., 1942, Digest of petrographic and related information on Shasta and Friant aggregate and concrete: U.S. Bureau Reclamation Petrographic Laboratory Report 35, 13 p.

Rice, J.M., and Ferns, M.L., 1980, Significance of metarodingite in the Wranle Gap-Red Mountain Ultramafic complex, Klamath Mountains, Oregon: Geological Society of America, Abstracts with Programs, v. 12, no. 3, p. 149.

Rice, S.J., 1956, Nickeliferous laterite in northwestern California: Geological Society of America Bulletin, v. 67 , no. 12 , pt. 2, p. 1779-1780.

Rich, E.I., and Steele, W.C., 1974, Speculations on geologic structures in northern California as detected from ERTS-1 satellite imagery: Geological Society of America, Geology, v. 2, no. 4, p. 165-169.

Rich, M., 1977, Pennsylvanian paleogeographic patterns in the western United States, in Paleozoic paleogeography of the western United States, Stewart, J.H., Stevens, C.H., and Fritache, A.E., eds.: Society of Economic Paleontologists and Mineralogists, Pacific Section, Pacific Coast Paleogeography symposium 1 , p. 87-111.

Richardson, B., and Bosted, B., 1989, Sunbeam Cave: Califoinia Caver, v. 39, no. 1, p. 9-11.

Riddihough, R., Finn, C., and Couch, R., 1986, Klamath-Blue Mountain lineament, Oregon: Geology, v. 14 , no. 6, p. 528-531.

Rigby, J.K., and Potter, A.W., 1980, Ordovician Sphinctozoan sponges from the Klamath Mountains, California, the first known early Paleozoic occurrence: Geological Society of America, Abstracts with Programs, v. 12, no. 7, p. 509.

---1986, Ordovician Sphinctozoan sponges from the eastern Klamath Mountains, northern California: Paleontology Society Memoir 20, Journal of Paleontology:, no. 4, p. 1-47 supplement.

Riley, T.A., 1988, The petrogenetic evolution of a Late Jurassic island arc; the Rogue Formation, Klamath Mountains, Oregon: Stanford University, M.Sc. thesis, 40 p.

Riley, T.A., and Coleman, R.G., 1987, Petrogenetic evolution of the Rogue Formation: Late Jurassic submarine volcanic rocks of the Western Jurassic belt, Klamath Mts., Oregon: Geological Society of America Abstracts with Programs, v. 19, no. 6, p. 443.

Ripperdan, R.L., and Kirschvink, J.L., 1989, Did Siberia play a role in the assembly of the North American western margin?: Geological Society of America Abstracts With Programs, v. 21, no. 5, p. 134.

Roehl, P.O., 1955, The Paleozoic geosyncline of the Klamath Mountains, California: Madison, Wisconsin University, Ph.D. dissertation, 159 p.

Rogers, J.J.W., 1966, Geochemical significance of the source rocks of some graywackes from western Oregon and Washington: Texas Journal of Science, v. 18, no. 1, p. 5-20. 
Rogers, J.J.W., and McKay, S.M., 1972, Chemical evolution of geosynclinal material, in Studies in mineralogy and Precambrian geology: Geological Society of America Memoir 135, p. 3-28.

Rogers, J.J.W., and others, 1974, Paleozoic and Lower Mesozoic volcanism and continental growth in the western United States: Geological Society of America Bulletin, v. 85, no. 12, p. 1913-1924.

Rohr, D.M., 1972, Geology of the Lover's Leap area, China Mountain quadrangle, California: Corvallis, Oregon State University, M.S. thesis, 95 p.

---1978, Stratigraphy, structure, and early Paleozoic Gastropoda of the Callahan area, Klamath Mountains, California: Corvallis, Oregon State University, Ph.D dissertation, 340 p.

---1980, Ordovician-Devonian Gastropods from the Klamath Mountains, California: Paleontographica. Abteilung A: Palaeozoologie-Stratigraphie, v. 171, no. 4-6, p. 141-210.

Rohr, D., and Boucot, A.J., 1971, Northern California (Klamath Mountains) pre-Late Silurian igneous complex: Geological Society of America, Abstracts with Programs, California, v. 3, no. 2, p. 186.

Rohr, D.M., Boucot, A.J., and Potter, A.W., 1974, Age corrections for some Silurian localities in northern California: Journal of Paleontology, v. 48, no. 2, p. 413-414.

---1975, Age of fossils from lower Paleozoic rocks, eastern Klamath Mountains, California: Journal of Paleontology, v. 49, p. 427-429.

Rohr, D.M., and Potter, A.W., 1973, Paleozoic rocks of the Callahan-Gazelle area, Klamath Mountains, northern California: Geological Society of America, Abstracts with Programs, v. 5, no. 1, p. 97.

Romey, W.D., 1962, Geology of a part of the Etna quadrangle, Siskiyou County, California: Berkeley, California University, Ph.D. dissertation, 93 p.

---1962, Russian Peak batholith, Klamath Mountains, northern California: Geological Society of America Special Paper 73, p. 227.

Ross, C.A., 1976, Fusulinacean provinces of North American Cordillera: American Association of Petroleum Geologists, Bulletin 60, no. 4, p. 715-716.

---1991, Pennsylvanian paleogeography of the western United States, in Cooper, J.D., and Stevens, C.H., eds., Paleozoic Paleogeography of the western United States II: Society Economic Paleontologists and Mineralogists, Pacific Section, v. 67, p. 137-148.

Ross, C.A., and Ross, J.R.P., 1983, Late Paleozoic accreted terranes of western North America, in Stevens, C.H., ed., Pre-Jurassic rocks in western North America suspect terranes: Society of Economic Paleontologists and Mineralogists, Pacific Section, p. 7-22.

Ross, R.J., Jr., 1977, Ordovician paleogeography of the western United States, in Stewart, J.H., Stevens, C.H., and Fritsche, A.E. eds, Paleozoic paleogeography of western United States, Pacific Coast Paleogeograpy Symposium: Bakersfield, Ca., Pacific Section SEPM, p. 19-38.

Rouer, O, and Lapierre, H., 1989, Comparison between two Palaeozoic island-arc terranes in northern California (eastern Klamath and northern Sierra Nevada): geodynamic constraints: Tectonophysics, v. 169, no. 4, p. 341-349.

Rouer, O., Lapierre, H., Mascle, G., Coulon, C., and Albers, J., 1989, Geodynamic implications of Devonian silicic arc magmatism in the Sierra Nevada and Klamath Mountains, California: Geology, v. 17, no. 2, p. 177-180.

Roure, F., 1980, Un profil geologique dans les chaines de l'Ouest americain (Californie et Oregon): International Geological Congress Abstract, Resumes 26, p. 384.

---1981, Tectonique des chaines de l'Oregon occidental (U.S.A): une coupe du front des Monts Klamaths au Pacifique: Bulletin de la Societe Geologique de France, v. 23, no. 5, pp. 457-466.

---1982, Mise en évidence d'une tectonique majeure du Jurassique supériere (phase névadienne) dans le Nord-Est de l'Oregon (secteur d'Huntington): C.R. Academie Sciences, Paris II, v. 294, no. 15, p. 921925.

---1983, Mise en évidence de déformations liasiques dans les Blue Mountains et la chaine des Klamath, Californie et Oregon: Terra Cognita v. 3, p. 259.

---1983, Nouvelles données sur les effets de l'orogenèse névadienne (Jurassique supérieur) dans la chaîne des Klamath nord-ouest de la Californie et sud-ouest del'Orégon, États- Unis: C.R. Academie Sciences, Paris, II, v. 296, no. 10, p. 791-796.

---1983, New data on vergence and tectonic history of the Klamath Mountains: Geological Society of America, Abstracts with Programs, v. 15, no. 5, p. 426.

---1984, Une coupe geologique de Golconda au Pacifique (Oregon, nord-ouest du Nevada, nord de la Californie): evolution Mesozoique et Cenozoique de la marge ouest-Americaine: Paris, Pierre and Marie Curie University, Academie de Paris, Ph.D. dissertation, Memories des Sciences de la Terre, 
$250 \mathrm{p}$.

Roure, F., and Blanchet, R., 1983, A geological transect between the Klamath Mountains and the Pacific Ocean (southwestern Oregon): a model for paleo-subductions: Tectonophysics, v. 91, p. 53-72.

Roure, F., and DeWever, P., 1983, Decouverte de radiolarites du Trias dans l'unite occidental des Klamath, sudouest de l'Oregon, U. S. A.: Consequences sur l'age des peridotites de Josephine: Comptes Rendus de l'Academie des Sciences de Paris, v. 297, p. 161-164.

Roure, F., and Sosson, M., 1986, Late Jurassic collision between a composite exotic block and the North American continent; a model for the Cordillera building: Bulletin de la Société Geologique de France, v. 8, II, no. 6, p. 945-959.

Routher, P., 1964, Nickeliferous laterites in southwestern California: Economic Geology, v. 59, no. 7, p. 1396.

Rowe, W.A., Mejia, V.M., Cumberlidge, J.T., and Mattson, L.A., 1976, Geology of the Nickel Mountain Mine, Riddle, Oregon, in World mining and metals technology, Weiss, A., (ed.), Mining and Metallurgical Institute of Japan, Tokyo, and American Institute Mining, Metallurgical and Petroleum Engineering, New York, NY, p. 25-46.

Rowland, R.E., 1966, Geology of the Grouse Creek area, South Fork Mountains, California: Los Angeles, California University, M.A. thesis, 106 p.

Rubin, C.M., Miller, M.M., and Smith,G.M., 1990, Tectonic development of cordilleran mid-Paleozoic volcano-plutonic complexes; evidence for convergent margin tectonism, in Harwood, D.S., and Miller, M.M., eds., Paleozoic and early Mesozoic paleogeographic relations; Sierra Nevada, Klamath Mountains, and related terranes: Geological Society of America, Special Paper 255, p. 116.

Rubin, C.M., Smith, G., and Miller, M.M., 1989, The geologic evolution and tectonic setting of mid-Paleozoic arc basement in the North American Cordillera: Geological Society of America Abstracts With Programs, v. 21, no. 5, p. 137.

Rudmann, J.E., 1970, The zonal distribution and mineralization of nickel in saprolite ore from Nickel Mountain, Riddle, Oregon: Cleveland, Case Western Reserve University, M.S. thesis, 72 p.

Russell, I.C., 1884, A geological reconnaissance in southern Oregon: U.S. Geological Survey, Annual Report 4, p. 431-464.

Russell, R.D., 1929, Fossil pearls from the Chico Formation of Shasta County, California: American Journal of Science, v. 18, no. 11, p. 416-428.

Rynearson, G.A., and Smith, C.T., 1940, Chromite deposits in the Seiad quadrangle, Siskiyou County, California: U.S. Geological Survey Bulletin 922-J, p. 281-306.

Saleeby, J.B., 1981, Ocean floor accretion and volcanoplutonic arc evolution of the Mesozoic Sierra Nevada, in W.G. Ernst, ed., The geotectonic development of California: Prentice-Hall, Inc., Rubey Volume I, p. 133-181.

---1983, Accretionary tectonics of the North American Cordillera: Annual Review of Earth and Planetary Sciences, v. 11, p. 45-73.

---1984, $\mathrm{Pb} / \mathrm{U}$ zircon ages from the Rogue River area, Western Jurassic belt, Klamath Mountains, Oregon: Geological Society of America, Abstracts with Programs, v. 16, p. 331.

---1987, Discordance patterns in $\mathrm{Pb} / \mathrm{U}$ zircon ages of the Sierra Nevada and Klamath Mountains: Eos (American Geophysical Union Trans.), v. 68, p. 1514-1515.

---1990, Geochronologic and tectonostratigraphic framework of Sierran-Klamath ophiolitic assemblages, in Harwood, D.S., and Miller, M.M., eds., Paleozoic and early Mesozoic paleogeographic relations; Sierra Nevada, Klamath Mountains, and related terranes; Geological Society of America Special Paper 255, p. 93-114.

---1992, Petrotectonic and paleogeographic settings of U.S. Cordilleran ophiolites, in Burchfiel, B.C., Lipman, P.W., and Zoback, M.L., eds., The Geology of North America Volume G-3, The Cordilleran Orogen: Conterminous U.S.: Geological Society of America, Boulder, Colorado, p. 653682.

Saleeby, J.B., Blake, M.C., and Coleman, R.G., 1984, Pb/U zircon ages on thrust plates of the west central Klamath Mountains and Coast Ranges, northern California and southern Oregon: Eos (American Geophysical Union Trans.), v. 65, no. 45, p. 1147.

Saleeby, J.B., and Busby-Spera, C., 1992, Early Mesozoic tectonic evolution of the western U.S. Cordillera, in Burchfiel, B.C., Lipman, P.W., and Zoback, M.L., eds., The Geology of North America Volume G-3, The Cordilleran Orogen: Conterminous U.S.: Geological Society of America, Boulder, Colorado, p. 107-168. 
Saleeby, J.B., and Harper, G.D., 1993, Tectonic relations between the Galice Formation and the Condrey Mountain Schist, Klamath Mountains, northern California, in Dunn, G., and McDougall, K., eds., Mesozoic paleogeography of the western United States-II: Society of Economic Paleontologists and Mineralogists, Pacific Section, Book 71, p. 61-80.

Saleeby, J.B., Harper, G.D., Snoke, A.W., and Sharp, W.D., 1980, Ophiolite accretion in west-central Klamath Mountains, California: Eos (American Geophysical Union Trans.), v. 61, no. 46, p. 948.

---1982, Time relations and structural-stratigraphic patterns in ophiolite accretion, west-central Klamath Mountains, California: Journal of Geophysical Research, v. 87, no. B5, p.3831-3848.

Saleeby, J.B., Mattinson, J.M., and Wright, J.E., 1979, Regional ophiolite terranes of California; vestiges of two complex ocean floor assemblages: Geological Society of America, Abstracts with Programs, v. 11, no. 7, p. 509.

Sanborn, A.F., 1953, Geology and paleontology of a part of the Big Bend quadrangle, Shasta County, California: Stanford University, Ph.D. dissertation.

---1960, Geology and paleontology of the southwest quarter of the Big Bend quadrangle, Shasta County, California: California Division of Mines Special Report 63, 26 p.

Sandberg, C.H., 1965, Geophysical survey of the Iron Mountain mine, in Economic geology of the French Gulch quadrangle, Shasta and Trinity Counties, California: California Division of Mines and Geology Special Report 85, p. 37-41.

Sanders, F.S., 1976, An investigation of carbon flux in sediment of Castle Lake, California: Davis, University of California, Ph.D. dissertation.

Sanzolone, R.F., and Domenico, J.A., 1985, Trace element content of gossans at four mines in the West Shasta massive sulfide district: Economic Geology, v. 80, no. 8, p. 2206-2212.

Savage, N.M., 1973, Devonian conodonts from the Klamath Mountains of northern California: Geological Society of America, Abstracts with Programs, v. 5, no. 1, p. 100.

---1974, Devonian conodont biostratigraphy in the southern Klamath Mountains: Oregon Academy of Science, Proceedings, v. 10, 70 p.

---1974, Conodont evidence of a Late Eifelian Age for the Kennett Formation: Geological Society of America, Abstracts with Programs, v. 6, no. 3, p. 248-249.

---1975, Devonian conodont biostratigraphy in the southern Klamath Mountains: Geological Society of America, Abstracts with Programs, v. 7, no. 3, p. 368-369.

---1976, Lower Devonian (Gedinnian) conodonts from the Grouse Creek area, Klamath Mountains, Northern California: Journal of Paleontology, v. 50,p. 1180-1190.

---1976, Middle Devonian species of Polygnathus from the Kennett Formation, northern California: Journal of Paleontology, v. 50, p. 374-379.

---1977, Lower Devonian conodonts from the Gazelle Formation, Klamath Mountains, northern California: Journal of Paleontology, v. 51, no. 1, p. 57-62.

Savage, N.M., and Boucot, A.J. , 1977, Evidence for an early Middle Devonian orogeny in northern California and Southeast Alaska: Proceedings of the Thirty-fifth annual meeting of the Oregon Academy of Science, Oregon Academy of Science, Proceedings, v. 13, p. 63.

---1978, Middle Devonian brachiopods from the Kennett Formation, northern California: Journal of Paleontology., v. 52, no. 4, p. 807-811.

Schmidt, B. L., 1994, The English Peak pluton (Klamath Mountains, California), A complex composite pluton: Geological Society of america, Abstracts with Programs, v. 26, no. 7, p. 292.

---1994, The petrology and geochemistry of the English Peak intrusive suite, Klamath Mountains, California: Lubbock, Texas Tech University, Ph. D. dissertation, 216 p.

Schmidt, B.L., and Barnes, C.G., 1990, Enclaves and enclave swarms in the English Peak pluton, Klamath Mountains, northern California: Geological Society of America, Abstracts with Programs, v. 22, no. 3, p. 81.

---1991, Chemical and petrologic characteristics of the English Peak intrusive sequence: Geological Society of America, Abstracts with Programs, v. 23, no. 2, p. 95.

Schoenike, H.G., 1954, Geology and exploration of the nickel silicate deposit at Riddle, Oregon: Madison, University of Wisconsin, M.S. thesis, $74 \mathrm{p}$.

Schuette, C.N., 1938, Quicksilver in Oregon: Oregon Department of Geology and Mineral Resources Bulletin 4, 172 p.

Schultz, K.L., 1983, Paleomagnetism in the Klamath Mountains, southern Oregon and northern California: Corvallis, Oregon State University, M.S. thesis, 153 p.

Schultz, K.L., and Levi, S., 1981, Paleomagnetism of the Upper Cretaceous Hornbrook Formation; 
implications for tectonic rotation of the Klamath Mountains Province: Eos (American Geophysical Union Trans.) v. 62 , no. 45 , p. 854.

Schultz, K.L., and Levi, S., 1983, Paleomagnetism of Middle Jurassic plutons of the north-central Klamath Mountains: Geological Society of America Bulletin Abstracts with Programs, v. 15, no. 5, p. 427.

Schwab, F.L., 1971, Geosynclinal compositions and the new global tectonics: Journal of Sedimentary Petrology, v. 41, no. 4, p. 928-938.

Schweickert, R.A., and Irwin, W.P., 1986, Tertiary detachment faulting in the Klamath Mountains, California: A new hypothesis: Geological Society of America, Abstracts with Programs, v. 18, no. 6, p. 742.

---1989, Extensional faulting in southern Klamath Mountains, California: Tectonics, v. 8, no. 1, p. 135149

Schweickert, R.A., and Snyder, W.S., 1981, Paleozoic plate tectonics of the Sierra Nevada and adjacent regions, in W.G. Ernst, ed., The geotectonic development of California: Prentice-Hall, New Jersey, Ruby Volume I, p. 182-201.

Schwindinger, K.R., and Anderson, A.T., Jr., 1987, Probable low-pressure intrusion of gabbro into serpentinized peridotite, northern California: Geological Society of America Bulletin, v. 98, no. 3, p. 364-372.

Scott, G.R., Renne, P.R., Bazard, D.R., and Johnston, J.M., 1985, Paleomagnetism of the Permian Nosoni Fm. ignimbrite and implications of accretionary models of Eastern Klamath belt tectonics: Geological Society of America Abstracts with Programs, v. 17, no. 6, p. 407.

Seager, G.F., 1939, Petrology of the Balaklala chonolith, Shasta County, California: Geological Society of America Bulletin, v. 50, no. 12, pt. 2, p. 1958-1959.

---1940, Geology of the Shasta copper belt: Geological Society of America Bulletin, v. 51, no. 12, pt. 2, p. 2031-2032.

Seeley, W.O., 1974, Geology of the southeastern quarter of the Dixonville quadrangle, Oregon: Eugene, University of Oregon, M.S. thesis, $77 \mathrm{p}$.

Serr, E.F., 1972, The sedimentation aspects of water resources: Simposio internacional sobre la planificacion de recursos hidraulicos; Resumenes, Secr. Recursos Hidraul. Subsecr., Planeacion, Mexico City, Mexico, p. 153.

Seyfert, C., Jr., 1965, Compositional variation within the English Peak batholith in northern California: Geological Society of America Special Paper 82, p. 278.

---1965, Geology of the Sawyers Bar area, Klamath Mountains, northern California: Stanford, California, Stanford University, Ph.D. dissertation, 227 p.

---1968, Continental accretion during the Paleozoic and Mesozoic in the Klamath Mountains of northern California: American Geophysical Union Transactions, v. 49, no. 1, p. 326.

---1974, Geology of the Sawyers Bar quadrangle, in Geologic guide to the southern Klamath Mountains: Geological Society of Sacramento, Annual Field Trip guidebook, p. 69-81.

Sharp, R.P., 1960, Pleistocene glaciation in the Trinity Alps of northern California: American Journal of Science, v. 258, p. 305-340.

Sharp, W.D., and Wright, J.E., 1981, Jurassic metavolcanic sequences in the western Sierra-Klamath provinces: character and Tectonic significance: Geological Society of America, Abstracts with Programs, v. 13, no. 2, p. 105.

Sheehan, P.M., and Boucot, A.J., 1991, Silurian paleogeography of the western United States, in Cooper, J.D., and Stevens, C.H. eds., Paleozoic Paleogeography of the western United States II: Society of Economic Paleontologists and Mineralogists, Pacific Section, v. 67, p. 51-82.

Shenon, P.J., 1933, Geology and ore deposits of the Takilma-Waldo district, Oregon, including the Blue district: U.S. Geological Survey Bulletin 846-B, p. 141-194.

---1933, Copper deposits in the Squaw Creek and Silver Peak districts and at the Almeda mine, southwestern Oregon, with notes on the Pennell and Farmer and Banfield prospects: U.S. Geological Survey Circular 2, $35 \mathrm{p}$.

---1933, Geology of the Robertson, Humdinger, and Robert E. gold mines, southwestern Oregon: U.S. Geological Survey Bulletin 830, p. 33-55.

Sheppard, R.A., and Gude, A.J., III, 1969, Rhodesite from Trinity County, California: American Mineralogist, v. 54, nos. 1-2, p. 251-255.

Short, N.M., 1987, Terranes as terrains: A geomorphic study of the Klamath Mountains: Geological Society of America, Abstracts with programs, v. 19, no. 7, p. 843. 
Short, P.F., and Ingersoll, R.V., 1990, Petrofacies and provenance of the Great Valley Group, southern Klamath Mountains and northern Sacramento Valley, in Ingersoll, R.V., and Nilsen, T.H., eds., Sacramento Valley Symposium and Guidebook: Society of Economic Paleontologists and Mineralogists, Pacific Section, Book 65,

Shurkin, J., 1983, Stanford geology in the Klamath Mountains: California Mining Journal, v. 52, no. 5, p. 4-6.

Silberling, N.J., 1973, Geologic events during Permian-Triassic time along the Pacific margin of the United States, in the Permian and Triassic systems and their mutual boundary: Alberta Society of Petroleum Geology, Calgary, Alberta, Canada, p. 345-362.

Silberling, N.J., and Irwin, W.P., 1962, Triassic fossils from the southern Klamath Mountains, California: U.S. Geological Survey Professional Paper 450-B, art. 23, p. B60-B61.

Silberling, N,J., and Jones, D.L., 1982, Tectonic significance of Permian-Triassic strata in northwestern Nevada and northern California: Geological Society of America, Abstracts with Programs, v. 14, no. 4 , p. 234.

Silberman, M.L., Danielson, J., Erickson, M.S., and Grimes, D.J., 1987, Characteristics and geochemistry of gold-bearing quartz veins in the Redding 1 X 2 degree quadrangle, Klamath Mountains, CA: Geological Society of America Abstracts with Programs, v. 19, no. 6, p. 451.

Silberman, M.L., and Danielson, J., 1991, Geologic setting, characteristics, and geochemistry of goldbearing quartz veins in the Klamath Mountains in the Redding 1 X 2 degree quadrangle, northern California: U.S. Geological Survey Open-File Report 91-595, 27 p.

---1993, Gold-bearing veins in the Klamath Mountains in the Redding 1 X 2 degree quadrangle, northern California: California Geology, March/April, p. 35-44.

Silberman, M.L., Hassemer, J.R., and Smith, S.M., 1991, Regional geochemical signatures of lode Au and $\mathrm{Cu}$ deposits in the western half of the Redding $1^{\circ} \times 2^{\circ}$ quadrangle, northern California:

Association of Exploration Geochemists, 15th International Geochemical Exploration Symposium, Program with Abstracts, p. 39.

Silberman, M.L., Hassemer, J.R., Force, J., and Tripp, R.B., 1993, Delineation of terranes favorable for the occurrence of lode glod deposits in the Coast Ranges and western Klamath Mountains, western half of the Redding 1 X 2 degree quadrangle, northern California, in Field guide and abstracts: NAGT-FWS FALL 1993 Meeting, Bridge Bay Resort, CA, P. A23.

---1994, Assessment of mineral resource potential of the western half of the Redding 1:250,000 quadrangle, northwestern California: U.S. Geological Survey, Open-File Report 93-0296, 44 p., 24 figs.

Simpson, R.W., and Cox, A., 1977, Paleomagnetic evidence for tectonic rotation of the Oregon Coast Range: Geology, v. 5, p. 585-589.

Sims, M., 1979, Alpine karst of the Marble Mountains wilderness: National Speleological Society Bulletin, Abstracts of Papers, 1978 National Speleological Society Convention, v. 41, no. 4, p. 113.

---1984, Marble Mountains: Organization of a large cave survey and mapping project: California Caver, v. 35, no. 3, p. 30-31.

Sims, M., and Knutson, S., 1983, Cave exploration in the Klamath Mountains, in Thomas, R.G., ed., Proceedings of the annual meeting of the National Speleological Society: National Speleological Society Bulletin, v. 45, no.1.

Sinclair, W.J., 1904, The exploration of Potter Creek cave: California University Publication of American Archeology and Ethnology, v. 2, p. 1-27.

Sinclair, W.J., and Furlong, E.L., 1904, Euceratherium, A new ungulate from the Quaternary caves of California: California University Publications in Geological Science, v. 3, no. 20, p. 411-418.

Singer, D.A., Page, N.J., Smith, J.G., Blakely, R.J., and Johnson, M.G., 1982, Mineral resource assessment of the Medford 1 by 2 degree quadrangle, Oregon: U.S. Geological Survey, Open-File Report OF 82-1037, 29 p.

---1983, Mineral resource assessment maps of the Medford $1^{\circ}$ by $2^{\circ}$ quadrangle, Oregon and California: U.S. Geological Survey, Miscellaneous Field Studies Map MF-1383-C, 2 sheets, scale 1:250,000.

Siskiyou County Historical Society, 1957, Guidebook to Siskiyou's gold fields: Siskiyou Pioneer, v. 2, no. $10,88 \mathrm{p}$.

Skinner, J.W., and Wilde, G.L., 1965, Permian biostratigraphy and fusulinid faunas of the Shasta Lake area, northern California: Kansas University Paleontology Contributions, Harold N. Fiske Memorial Papers, Protozoa, art. 6, 98 p.

---1970, Pseudofusulina californica, new name for Pseudofusulina tenuis Skinner and Wilde: Journal of 
Paleontology, v. 43, no. 6, p. 1441.

Slawson, W.F., 1983, Isotopic composition of lead from a paleo-island arc; Shasta, California: Canadian Journal of Earth Sciences, v. 20, no. 10, p. 1521-1527.

Sliter, W.V., Jones, D.L., and Throckmorton, C.K., 1984, Age and correlation of the Cretaceous Hornbrook Formation, California and Oregon, in Nilsen, T.H., ed., Geology of the Upper Cretaceous Hornbrook Formation, Oregon and California: Society of Economic Paleontologists and Mineralogists, Pacific Section, v. 42, p. 89-98.

Smith, J.G., Blakely, R.J., Johnson, M.G., Page, N.J., Peterson, J.A., Singer, D.A., and Whittington, C.L., 1986, The Conterminous United States Mineral Appraisal Program: Background information to accompany folio of geologic, geochemical, geophysical, and mineral resource maps of the Medford $1^{\circ}$ by $2^{\circ}$ quadrangle, Oregon and California: U.S. Geological Survey Circular 976,15 p.

Smith, J.G ., and Page, N.J., 1977, Preliminary reconnaissance geologic map of part of Jackson County, Oregon: U.S. Geological Survey Open-File Report 77-318, scale 1:250,000.

Smith, J.G., Page, N.J., Johnson, M.G., Moring, B.C., and Gray, F., 1982, Preliminary geologic map of the Medford $1^{\circ} \times 2^{\circ}$ quadrangle, Oregon and California: U.S. Geological Survey, Open-file Report 82-955, scale 1:250,000.

Smith, J.L., Metcalf, R.V., and Wallin, E.T., 1999, Geochemical comparison of Silurian and Devonian mafic intrusive complexes, Trinity terrane, CA,: Evidence of 33 million years of supra-subduction magmatism in a proto-arc setting: Geological Society of America, Abstracts with Programs, v. 31, no. 6, p. 96.

Smith, J.P., 1894, The metamorphic series of Shasta County, California: California Journal of Geology, v. 2, p. 588-612.

---1894, Trias and Jura of Shasta County, California: American Geologist, v. 14, p. 200.

---1894, The Carboniferous strata of Shasta County, California: American Geologist, v. 14, p. 203.

---1895, Supplementary notes on the metamorphic series of the Shasta region of California: American Geologist, v. 16, p. 249.

---1910, The geologic record of California: Journal of Geology, v. 18,p. 216-227.

---1914, The middle Triassic marine invertebrate faunas of North America: U.S. Geological Survey Professional Paper 83, 254 p.

---1927, Upper Triassic marine invertebrate faunas of North America: U.S. Geological Survey Professional Paper 141, 262 p.

Smith, R.M., and Peterson, J.A., 1985, Mineral deposits and probability of exploration, Medford $1^{\circ}$ by $2^{\circ}$ quadrangle, Oregon and California: U. S. Geological Survey, Miscellaneous Field Studies Map MF-1383-F, 33 p., with 4 maps, scale 1:250,000.

Smith, W.D., 1916, Notes on radiolarian cherts in Oregon: American Journal of Science, no. 4, p. 299-300, 504.

Snetsinger, K.G., 197l, A platinum-metal nugget from Trinity County, California: American Mineralogists, v. 56, no. 5-6, p. 1101-1105.

Snoke, A.W., 1971, A thrust plate of ophiolitic rocks in the Preston Peak area, Klamath Mountains, northwestern California: Geological Society of America, Abstracts with Programs, v. 3, no. 2, p. 198.

---1972, Petrology and structure of the Preston Peak area, Del Norte and Siskiyou Counties, California: Stanford, California, Stanford University, Ph.D. dissertation, $274 \mathrm{p}$.

---1973, Spinifex ultramafic rocks in the Preston Peak ophiolite, Klamath Mountains, California: Geological Society of America, Abstracts with Programs, v. 5, no. 1, p. 109.

---1974, Contrasting ultramafic-mafic rock suites in the Preston Peak area, Klamath Mountains, California: Geological Society of America, Abstracts with Programs, v. 6, no. 3, p. 257-258.

---1974, Geologic road log along U.S. Highway 299, between Shasta and Gray Falls Campground, California, in D.F.R. McGeary, ed., Geologic guide to the southern Klamath Mountains: Geological Society of Sacramento, Annual Field Trip Guidebook, p. 110-115.

---1977, A thrust plate of ophiolitic rocks in the Preston Peak area, Klamath Mountains, California: Geological Society of America Bulletin, v. 88, no. 11, p. 1641-1659.

Snoke, A.W., and Barnes, C.G., 2002, Anatexis and dynamothermal metamorphism during the emplacement of a syntectonic oceanic arc-root pluton, Klamath Mountains, California: Geological Society of America, Abstracts with Programs, v. 34, no. 5, p. A-22.

Snoke, A.W., and Bowman, H.R., 1977, Intrusive clinopyroxene-rich ultramafic and associated rocks in the Klamath Mountains-Sierra Nevada batholithic belt: Geological Society of America, 
Abstracts with Programs, v. 9, no. 4, p. 503.

Snoke, A.W., Bowman, H.R., and Herbert, A.J., 1977, The Preston Peak ophiolite, Klamath Mountains, California, an immature island arc: Petrochemical evidence: California Division of Mines and Geology Special Report 129, p. 67-79.

Snoke, A.W., and Calk, L.C., 1978, Jackstraw-textured talc-olivine rocks, Preston Peak area, Klamath Mountains, California: Geological Society of America, Bulletin, v. 89, no. 2, p. 223-230.

Snoke, A.W., Quick, J.E., and Bowman, H.R., 1981, Bear Mountain igneous complex, Klamath Mountains, California: an ultrabasic to silicic calc-alkaline suite: Journal of Petrology, v. 22, no. 4, p. 501-552.

Snoke, A.W., Sharp, W.D., Wright, J.E., and Saleeby, J.B., 1982, Significance of mid-Mesozioc peridotitic to dioritic intrusive complexes, Klamath Mountains-western Sierra Nevada, California: Geology, v. 10, no. 3, p. 162-166.

Snoke, A.W., and Whitney, S.E., 1979, Relict pyroxenes from the Preston Peak Ophiolite, Klamath Mountains, California: American Mineralogist, v. 64, no. 7-8, p. 865-873.

South, B.C., 1984, Mineralogy and stable isotope geochemistry of the Devonian Iron Mountain massive sulfide deposit, Shasta County, California: Davis, California University, M.Sc. thesis.

South, B.C., and Taylor, B.E., 1985, Stable isotope geochemistry and metal zonation at the Iron Mountain mine, West Shasta district, California: Economic Geology, v. 80, no. 8, p. 2177-2195.

Spencer, C.H., Jr., 197l, Statistical correlation of platinum metals with heavy minerals in stream sediments of the Klamath Mountains, California: San Jose, California State University, M.S. thesis, $62 \mathrm{p}$.

Stanley, G.D., Jr., 1979, Paleoecology, structure, and distribution of Triassic coral buildups in western North America,: Kansas University, Paleontology, Contributions, Article, no. 65, 58 p., Contribution no. 1979-9, University of Kansas, Department of Geology.

Staude, J.G., and Moring, B.C., 1988, Emplacement of the Walker Point mafic-ultramafic pluton, southeastern Klamath Mountains, California: Geological Society of America, Abstracts with Programs, v. 20, no. 3, p. 234-235.

Stauffer, C.R., 1930, The Devonian of California: California University Publication, Geological Science, v. 19 , no. 4, p. 81-118.

Stein, E., 1984, A field trip to Trinity County: Lapidary Journal, v. 38, no. 1, p. 46-48.

Stevens, C.H., 1977, Permian depositional provinces and tectonics, western United States, in Stewart, J.H., Stevens, C.H., and Fritche, A.E.,eds., Paleozoic paleogeography of the western United States: Society of Economic Paleontologists and Mineralogists, Pacific Section, Pacific Coast Paleogeography symposium 1, p. 113-135.

---1985, Reconstruction of Permian paleogeography based upon distribution of Tethyan faunal elements, in Dutro, J.T., and Pfefferkorn, H.W., eds., Neuvieme Congres international de Stratigraphie et de Geologie du carbononifere, May 17-26, 1979: Compte Rendu: Carbondale, Illinois, Southern Illinois University Pre, p. 383-393.

---1985, Permian colonial rugose corals and fusulinids in western North American tectonostratigraphic terranes: Eos (American Geophysical Union Trans.), v. 66, no. 46, p 862.

---1989, Comparison of early Permian coral faunas of the eastern Klamath Mountains, Stikine terrane, and cratonal Nevada and California: Geological Society of America, Abstracts with Programs, v. 21, no. 5 , p. 149.

---1991, Permian paleogeography of the western United States, in Cooper, J. D., and Stevens, C. H., eds., Paleozoic paleogeography of the western United States-II: Society of Economic Paleontologists and Mineralogists, Pacific Section, v. 67, p. 149-166.

Stevens, C.H., Lukin, M.D., and Nestell, M.K., 1991, The Upper Permian fusulinids Reichelina and Pararechelina in northern California: Evidence for long-distance transport, in Cooper, J.D. and Stevens, C.H., eds., Paleozoic Paleogeography of the Western United States II: Society of Economic Paleontologists and Mineralogists, Pacific Section, v. 67, p. 635-642.

Stevens, C.H., Miller, M.M., Nestell, M., 1987, A new Permian Waagenophyllid coral from the Klamath Mountains, California: Journal of Paleontology, v. 61, p. 690-699.

Stevens, C.H., and Rycerski, B.A., 1983, Permian colonial rugose corals in the western Americas--aids in positioning of suspect terranes, in C.H. Stevens, ed., Pre-Jurassic rocks in western North America suspect terranes: Society of Economic Paleontologists and Mineralogists, Pacific Section, p. 23-33.

---1988, The eastern Klamath Mountains Permian coral province, western North America; Geological Society of America, Abstracts with Programs, v. 20, no. 3, p. 235. 
Stevens, C.H., Yancey, T.E., and Hanger, R.A., 1990, Significance of the provincial signature of Early Permian faunas of the eastern Klamath terrane, in Harwood, D.S., and Miller, M.M., eds., Paleozoic and early Mesozoic paleogeographic relations; Sierra Nevada, Klamath Mountains, and related terranes; Geological Society of America Special Paper 255, p. 201-218.

Stevens, R.E., 1944, Composition of some chromites of the Western Hemisphere: American Mineralogist, v. 29, nos. 1, 2, p. 1-34.

Stewart, J.H., 1991, Latest Proterozoic and Cambrian rocks of the western United States - An overview, in Cooper, J.D., and Stevens, C.H. eds. Paleozoic Paleogeography of the western United States II, vol 1 and 2: Society Economic Paleontologists and Mineralogists, Pacific Section, v. 67, p. 13-37.

Stewart, J.H., and LaMarche, V.C., Jr., 1967, Erosion and deposition produced by the flood of December 1964 on Coffee Creek, Trinity County, California: U.S. Geological Survey Professional Paper 422-K, p. K1-K22.

Stines, N.S., 1907, The geology of the Coffee Creek mining district, California: Mining and Scientific Press, v. 95, p. 25-26.

Stone, L., Moley, K., Aalto, K.R., and Renne, P.R., 1993, The Pliocene-Pleistocene sedimentary tectonic history of NW California: Geological Society of America Abstracts with Programs, v. 25, no. 5, p. 151-152.

Stopps, F.G., 1937, The Esterly placer mine: Seattle, University of Washington, B.S. thesis, 27 p.

Storms, W.H., 1913, The Trinity-Balaklala-Vulcan mines, Shasta County, California: Mining and Science Press, v. 107, p. 408-411.

Strand, R.G. (compiler), 1962, Geologic map of California, Redding sheet--Olaf P. Jenkins edition: California Division of Mines and Geology Map Sheet, scale 1:250,000.

---1963, Geologic map of California, Weed sheet--Olaf P. Jenkins edition: California Division of Mines and Geology Map Sheet, scale 1:250,000.

Strauss, R.C., 1983, Variations in plagioclase zoning in response to an evolving physiochemical environment; applications to the interpretation of crystallization processes in the Caribou Mountain pluton, California: Tempe, Arizona University, M. Sc. thesis.

Stumpf, G.D., 1979, Gold mining in Siskiyou County, 1850-1900: Siskiyou County Historical Society, Yreka, Calif., $140 \mathrm{p}$.

Sugget, R., 1983, A biological survey of the Marble Valley caves, in Thomas, R.G., ed., Proceedings of the annual meeting of the National Speleological Society: National speleological Society Bulletin, v. 45 , no. 1.

Swartley, A.M., 1939, Geological features of west coast chromite deposits: Mining and Metallurgy, v. 20, no. 386, p. 100.

Swinney, C.M., 1950, The Altoona quicksilver mine, Trinity County, California: California Journal of Mines and Geology, v. 46, p. 395-404.

Taliaferro, N.L., 1942, Geologic history and correlation of the Jurassic of southwestern Oregon and California: Geological Society of America Bulletin, v. 53, no. 1, p. 71-112.

Taliaferro, N.L., and Hudson, F. S., 1943, Genesis of the manganese deposits of the Coast Ranges of California: California Division of Mines Bulletin 125, p. 217-275.

Talley, K.L., 1976, Descriptive geology of the Redwood Mountain outlier of the South Fork Mountain Schist, northern Coast Ranges, California: Southern Methodist University, M.S. thesis, 86 p.

Taylor, B.E., and Cramer, R.S., 1983, Oxygen, hydrogen, and sulfur isotope geochemistry of the Gray Eagle $\mathrm{Cu}-\mathrm{Zn}$-Au deposit, Siskiyou County, California; fingerprint of a paleo hydrothermal system: Geological Association of Canada, Annual Meeting, Program with Abstracts, v. 8, p. A67.

Taylor, B.E., and South, B.C., 1985, Regional stable isotope systematics of hydrothermal alteration and massive sulfide deposition in the West Shasta district, California: Economic Geology, v. 80, no. 8, p. 2149-2163.

Terres, M.A., 1979, The structure and petrology of the Forest Mountain ultramafic body, Klamath Mountains, California: Seattle, University of Washington, M.S. thesis, $92 \mathrm{p}$.

Thevenet, J.V., 1860, Sur les gisements auriferes et platiniferes de l'Oregon: Academie imperiale des Science, belles-lettres, et arts de Lyon, Classe des sci. Memoir 10, p. 129-134.

Thompson, A.G., 1988, Syn-metamorphic intrusions in the Observation Peak area, Klamath Mountains, southern Oregon: Lubbock, Texas Tech University, M. Sc. thesis, 95 p.

Thompson, A., Barnes, C.G., Helper, M., and Walker, N., 1988, Correlation of melange terranes, Klamath Mts, CA and OR: Geological Society of America Abstracts with Programs, v. 20, no. 7, p. A231. 
Thompson, H.M., 1957, King Solomon mine, Siskiyou County, California: The Siskiyou Pioneer, v. 2, no. 10, p. 14-18.

Thompson, M.L., Wheeler, H.E., and Hazzard, J.C., 1946, Permian fusulinids of California: Geological Society of America Memoir 17, 77 p.

Throckmorton, M., 1978, Petrology of the Castle Lake peridotite-gabbro mass, eastern Klamath Mountains, California: Santa Barbara, California University, M.S. thesis, 109 p.

Throckmorton, M.L., Villalobos, H.A., and Yamamoto, G.S., 1980, Leasable mineral and waterpower land classification map of the Weed $1^{\circ}$ by $2^{\circ}$ quadrangle, California and Oregon,: U.S. Geological Survey, Open-File Report no. 80-642, 1 sheet, scale 1:250,000.

Tischler, M.S., Oesterling, W.A., and Spurck, W.H., 1964, Minerals for industry, summary of geological survey of 1955-1961--V. 2, northern California: Southern Pacific Company, San Francisco, California, $207 \mathrm{p}$.

Tomlinson, A.J., and Wright, J.E., 1986, The Klamath-Sierran arc: a possible source region for Permian volcaniclastic and conglomeratic units within the Golconda allochthon: Geological Society of America, Abstracts with Programs, v. 18, no. 2, p. 193.

Tomlinson, S.L., 1993, Tectonostratigraphy of the Bolan Lake area, Klamath Mountains, Oregon: Lubbock, Texas Tech University, M.Sc. thesis, 84 p.

Tomlinson, S.L., and Barnes, C.G., 1991, Correlation of Rattlesnake Creek and western Hayfork terranes from California to Oregon, Klamath Mountains: Geological Society of America Abstracts with Programs, v. 23, no. 2, p. 104

Townsend, K., 1995, Petrology of unusual dacite dikes, La Grange fault, eastern Klamath Mountains, California: Arcata, California, Humboldt State University, B.Sc. thesis, 29 p.

Tozer, M.K., 1994, Tectonic and structural implications of the Cambrian Trinity plagiogranite, eastern Klamath Mountains, northern California, U.S.A.: Lincoln, University of Nebraska, M.Sc. thesis, $105 \mathrm{p}$.

Tozer, M.K., and Lindsley-Griffin, N., 1993, Trinity Complex plagiogranites, Klamath Mtns, California: Late Precambrian to early Paleozoic tectonism and magmatism: Geological Society of America, Abstracts with Programs, v. 25, no. 5, p. 156

Trabert, D.W., and Wallin, E.T., 1992, Sedimentology of the Gazelle Formation, northern California: Evidence for deposition in a trench-slope setting: Geological Society of America, Abstracts with Programs, v. 24, no. 5, p. 86.

Trask, J.B., 1855, Report on the geology of the Coast Mountains: California Senate Document no. 14, p. 50-53.

Trask, P.D., Wilson, I.F., and Simons, F.S., 1943, Manganese deposits of California, a summary report: California Division of Mines Bulletin 125, p. 51-215.

Trask, P.D., and others, 1950, Geologic descriptions of the manganese deposits of California: California Division of Mines Bulletin 152, 378 p.

Treasher, R.C., 1937, Oregon country geology; Placers of the upper Applegate, Jackson County: Geological Society of Oregon Country Geological News Letter, v. 3, no. 1, p. 3-4.

---1939, Earthquakes in Oregon, 1846-1938: Geological Society of Oregon Country Geological News Letter, v. 5, no. 23, p. 214-221, and no. 24, p. 224-226.

Trengove, R.R., 1960, Reconnaissance of California manganese deposits: U.S. Bureau of Mines Report Investigation $5579,46 \mathrm{p}$.

Trexler, D.T., 1968, Geology of the northwest quarter of the Cecilville quadrangle, Siskiyou County, California: Los Angeles, Southern California University, M.S. thesis, 133 p.

Tucker, W.B., 1922, Redding field division, Shasta, Siskiyou, and Trinity Counties: California State Mining Bureau, 18th Report State Mineralogist, p. 42-43; 96-97; 138-139; 206-207; 256-258; 295-298; 353-355; 405-413; 493-499; 595-601; 729-736.

---1922, Gold lodes of the East Fork mining district, Trinity County: California State Mining Bureau, 18th Report State Mineralogist, v. 18, chap. 6, p. 270-273.

---1922, Silver lodes of the South Fork mining district, Shasta County: California State Mining Bureau, 18th Report State Mineralogist, v. 18, chap. 7, p. 313-321.

---1923, Limestone deposits of McCloud River, Shasta County, and their possible value for cement material: California State Mining Bureau, 19th Report State Mineralogist, chap. 2, p. 69-71.

---1923, Redding field division, Shasta, Siskiyou, and Trinity Counties: California State Mining Bureau, 19th Report State Mineralogist, p. 89-94; 135-140.

---1924, Copper resources of Shasta County: California State Mining Bureau, 20th Report State 
Mineralogist, p. 419-447.

---1926, Silver lodes of the South Fork mining district, Shasta County: California State Mining Bureau Bulletin, v. 22, p. 201-210.

Turner, H.W., 1899, The occurrence and origin of diamonds in California: American Geologist, v. 23, p. 182-191.

---1903, The Cretaceous auriferous conglomerate of the Cottonwood mining district, Siskiyou County, California: Engineering and Mining Journal, v. 76, p. 653-654.

Uhrhammer, R.A., 1991, Northern California seismicity, in Slemmons, D. B., Engdahl, E. R., Zoback, M.D., and Blackwell, D.D., eds., Neotectonics of North America: Geological Society of America, Decade Map Volume 1, Chap. 7, p. 99-106.

U.S. Bureau of Reclamation, 1965, Geology; Design, Trinity Dam and powerplant, chapters 2-3 in Technical record of design and construction, Trinity River division features of the Central Valley project, California, v. 1: Denver, Colorado, U.S. Bureau of Reclamation, p. 13-62.

U.S. Geological Survey, 1943, Chromite deposits of McGuffy Creek area, Siskiyou County, California: California Journal of Mines and Geology, v. 39, no. 1, p. 92-94.

---1943, The Fairview and Ladd chromite deposits, Siskiyou County, California: California Journal of Mines and Geology, v. 39, no. 1, p. 94-96.

---1982, Aeromagnetic map of the Condrey Mountain area, California: U.S. Geological Survey Open-File Report 82-550, scale 1:62,500.

Vail, S.G., 1976, The Josephine Complex; an ophiolite in South-West Oregon, in Forslund, L.G., and others, eds., Proceedings of the Thirty-fourth annual meeting of the Oregon Academy of Science: Oregon Academy of Science, Proceedings, v. 12, p. 73.

---1977, Geology and geochemistry of the Oregon Mountain area, southwestern Oregon and northern California--an investigation of the origin and development of a Jurassic ophiolite in the Klamath Mountains: Corvallis, Oregon State University, Ph.D. dissertation, 159 p.

Vail, S.G., and Dasch, E.J., 1977, Jurassic ophiolitic rocks in the Klamath Mountains, S.W. Oregon and implications for pre-Nevadan paleogeography: Geological Society of America, Abstracts with Programs, v. 9, no. 4, p. 519-520.

Valloni, R., and Maynard, B., 1981, Detrital modes of recent deep-sea sands and their relation to tectonic setting: a first approximation: Sedimentology 28, p. 75-83.

Vehrs, R.A., 1961, Geologic features of the landslide in Excavation Area 2, Trinity Dam: California Association of Engineering Geologists, 4th Annual Meeting, Sacramento and Davis, Oct. 13-15, p. 7.

Vennum, W.R., 1971, Petrology of the Castle Crags pluton, Shasta and Siskiyou Counties, California: Stanford, California, Stanford University, Ph.D. dissertation, 183 p.

---1976, Petrology of the Castle Crags pluton: Geological Society of America, Abstracts with Programs, v. 8 , no. 3, p. 417-418.

---1980, Petrology of the Castle Crags Pluton, Klamath Mountains, California: Geological Society of America, Bulletin 91, no. 5, p. I 255-I 258, II 1332-II 1393.

---1994, Geology of Castle Crags, Shasta and Siskiyou Counties; a look at the geology and rock climbing possibilities in one of northern California's most scenic wilderness areas: California Geology, no. 2, p. 31-38.

Volney, C. D., 1870, California diamonds: Mining and Science Press, v. 20, no. 13, March 26, p. 194.

Wagner, D.L., 1988, Geology of Del Norte and Siskiyou Counties and adjacent portions of Humboldt, Shasta, and Trinity Counties: California Geology, v. 41, no. 12, p. 267-272.

Wagner, D.L., and Saucedo, G.J., 1982, Revised geologic map of the Weed Sheet, Klamath Mountains, Northern California: Geological Society of America, Abstracts with Programs, v. 14, no. 4, p. 242.

---1987, Geologic map of the Weed quadrangle, California: California Division of Mines and Geology, Regional Geologic Map Series, Map 4A, scale 1:250,000.

Wagner, N.S., and Ramp, L., 1958, Occurrences of peridotite-serpentine in Oregon: Ore Bin, v. 20, no. 2, p. 13-20.

Wahrhaftig, C., and Birman, J.H., 1965, The Quaternary of the Pacific mountain system in California, in The quaternary of the United States: Princeton, N.J., Princeton University Press, p. 299-340.

Waines, R.H., 1960, Stromatoporoids of the Kennett limestone, Shasta County, California: Geological Society of America Bulletin, v. 71, no. 12, pt. 2, p. 2081.

Walker, A.E., 1955, Exploration of Riddle Mountain nickel deposits [abs.]: A.I.M.E., Mining Geology Geophysics Division of Annual Meeting, Feb. 1955, Abstract Technical Papers, p. 28.

Walker, F.C., and Bock, R.W., 1972, Treatment of high embankment dam foundations: American 
Society of Civil Engineers, Proceedings, Journal of Soil Mechanics and Found. Division, v. 98, no. SMIO, p. 1099-1113.

Walker, G.W., and MacLeod, N.S., 1991, Geologic map of Oregon: U.S. Geological Survey Special Geologic Maps, 2 sheets, scale 1:500,000.

Wallin, E.T., 1986, Eocambrian-Early Cambrian plutonic rock in the Eastern Klamath province, northern California: Geological Society of America, Abstracts with Programs, v. 18, no. 2, p. 195.

---1988, Provenance of Lower Paleozoic sandstones in the eastern Klamath Mountains and the Roberts Mountains allochthon, California and Nevada: Lawrence, University of Kansas, Ph. D. dissertation, $152 \mathrm{p}$.

---1988, Evolution of lower Paleozoic terrigenous clastic sedimentation in the Yreka-Callahan area, eastern Klamath Mountains, California: Geological Society of America Abstracts with Programs, v. 20, p. 231.

---1989, Reconstruction of the timing and sequence of early Paleozoic sedimentation in the YrekaCallahan terrane, eastern Klamath Mountains, California: Geological Society of America, Abstracts with Programs, v. 21, no. 5, p. 155.

---1989, Petrogenetic and tectonic significance of xenocrystic Precambrian zircon in a Lower Cambrian tonalite, eastern Klamath Mountains, California: Geological Society of America, Abstracts with Programs, v. 21, no. 5, p. 155-156.

---1990, Petrogenetic and tectonic significance of xenocrystic Precambrian zircon in Lower Cambrian tonalite, eastern Klamath Mountains, California: Geology, v. 18, no. 11, p. 1057-1060.

---1990, Provenance of selected lower Paleozoic siliciclastic rocks in the Roberts Mountains allochthon, Nevada, in Harwood, D.S., and Miller, M.M., eds., Paleozoic and early Mesozoic paleogeographic relations; Sierra Nevada, Klamath Mountains, and related terranes; Geological Society of America Special Paper 255, p. 17-32.

---1993, Sonomia revisited: Evidence for a western Canadian provenance of the eastern Klamath and northern Sierra Nevada terranes, California: Geological Society of America, Abstracts with Programs, v. 25, p. 173.

---1999, Geological overview of a mid-Paleozoic intraoceanic convergent margin, eastern Klamath Mountains, California in Hirt, W. H., ed., Across the Klamath / Cascade Frontier: National Association of Geoscience Teachers, Far Western Scetion, Fall Field Conference, Sept. 17-19, Guidebook, p. 1-31.

Wallin, E.T., Coleman, D.S., Lindsley-Griffin, N., and Potter, A.W., 1995, Silurian plutonism in the Trinity terrane (Neoproterozoic and Ordovician), Klamath Mountains, California, United States: Tectonics, v. 14, no. 4, p. 1007-1013.

Wallin, E.T., and Gehrels, G.E., 1995, Sedimentary record of Silurian volcanism reveals denudation of the Trinity terrane and timing of siliclastic sedimentation of the Yreka terrane, northern California: Geological Society of America, Abstracts with Programs, v. 27, no. 5, p. 83.

Wallin, E.T., Lindsley-Griffin, N., and Griffin, J.R., 1991, Amalgamation of Cambrian and Ordovician terranes along a pre-Late Silurian suture, eastern Klamath Mountains, California: Geological Society of America, Abstracts with Programs, v. 23, no. 2, p. 107.

---1991, Overview of early Paleozoic magmatism in the eastern Klamath Mountains, California: An isotopic perspective, in Cooper, J.D. and Stevens, C.H., eds., Paleozoic Paleogeography of the Western United States II: Society of Economic Paleontologists and Mineralogists, Pacific Section, v. 67, p. $581-588$.

---1991, Overview of early Paleozoic magmatism in the eastern Klamath Mountains, California: American Association of Petroleum Geologists Bulletin, v. 75, no. 2, p. 385.

---1992, Early Paleozoic tectonics and sedimentation, Yreka and Trinity terranes, northern California: Geological Society of America,Cordilleran Section Meeting Field Guide, Trip no. 7, 38 p.

Wallin, E.T., Lindsley-Griffin, N., and Potter, A.W., 1990, Trinity ultramafic complex, Klamath Mountains, California: Cambro-Ordovician ophiolite or composite terrane?: Geological Society of America, Abstracts with Programs, v. 22, no. 3, p. 91-92.

Wallin, E.T., Mattinson, J.M., and Potter, A.W., 1988, Early Paleozoic magmatic events in the eastern Klamath Mountains, northern California: Geology, v. 16, no. 2, p. 144-148.

Wallin, E.T., and Metcalf, R.V., 1997, Superposed Silurian and Devonian mafic intrusive complexes, Trinity terrane, California: Geological Society of America, Abstracts with Programs, v. 29, no. 6, p. 348.

---1998, Supra-subduction zone ophiolite formed in an extensional forearc, Trinity terrane, California: 
Journal of Geology, v. 106, p. 591-608.

Wallin, E.T., Noto, R.C., and Gehrels, G.E., 2000, Provenance of the Antelope Mountain Quartzite , Yreka terrane, California; evidence for large-scale late Paleozoic sinistral displacement along the North American Cordilleran margin and implications for the mid-Paleozoic fringing-arc model, in Soreghan, M.J., and Gehrels, G.E., eds., Paleozoic and Triassic paleogeography and tectonics of western Nevada and norhern California: Geological Society of America, Special Paper 347, p. 119131.

Wallin, E.T., and Trabert, D.W., 1992, Structural context \& stratigraphy of a Devonian trench-slope basin, Klamath Mountains, California: Geological Society of America, Abstracts with Programs, v. 24 , no. 5 , p. 88 .

---1994, Eruption-controlled epiclastic sedimentation in a Devonian trench-slope basin: Evidence from sandstone petrofacies, Klamath Mountains, California: Journal of Sedimentary Research, v. 64, no. 2, p. 373-385.

Walsh, M.R., 1994, Gold at Reading's Bar, Clear Creek, Shasta County: Dogtown Territorial Quarterly, no. 17, Spring, p. 8, 9, 38, and 39.

Wardlaw, B.R., and Jones, D.L., 1980, Triassic conodonts from eugeoclinal rocks of western North America and their tectonic significance, in Gaetani, M., ed., Contributions to the Triassic stratigraphy: Riv. Italiana Paleontolgia Stratigrafia v. 85, no. 3-4, p. 895-908, tav. 64.

Waring, G.A., 1915, Springs of California: U.S. Geological Survey Water-Supply Paper 338, 410 p.

Washburne, J.C., 1982, Parameterization of spectral induced polarization data and laboratory and in situ spectral induced polarization measurements; West Shasta copper-zinc district, Shasta, CA: Golden, Colorado School of Mines, M. S. thesis, 443 p.

Watkins, R., 1972, A report on the Carboniferous System between Hirz Mountain and Kabyai Creek, Shasta County, northern California: Berkeley, California University, M.A. thesis, 154 p.

---1973, Carboniferous faunal associations and stratigraphy, Shasta County, northern California: American Association of Petroleum Geologists Bulletin, v. 57, no. 9, p. 1743-1764.

---1974, Carboniferous Brachiopods from northern California: Journal of Paleontology, v. 48, no. 2, p. 304-325.

---1975, Paleoecology of some Carboniferous Pectinacea: Lethaia, v. 8, no. 2, p. 125-131.

---1979, Carboniferous rocks of the eastern Klamath Mountains, California, in The Mississippian and Pennsylvanian (Carboniferous) Systems in the United States: U. S. Geological Survey Professional Paper 1110-CC, p. CC33-CC38.

---1985, Relationship of volcaniclastic and carbonate sedimentation in the late Paleozoic Baird Formation and McCloud Limestone, eastern Klamath Mountains, California: Geological Society of America, Abstracts with Programs, v. 17, no. 6, p. 417.

---1985, Volcaniclastic and carbonate sedimentation in late Paleozoic island-arc deposits, eastern Klamath Mountains: Geology, v. 13, no. 10, p. 709-713.

---1986, Late Devonian to Early Carboniferous turbidite facies and basinal development of the eastern Klamath Mountains, California: Sedimentary Geology, v. 49, p. 51-71.

---1986, Reply on "Volcaniclastic and carbonate sedimentation in late Paleozoic island-arc deposits, eastern Klamath Mountains, California: Geology, v. 14, no. 6, p. 539.

---1990, Carbonate bank sedimentation in Carboniferous island arc deposits, Eastern Klamath terrane, California: Geological Society of America, Abstracts with Programs, v. 22, no. 3, p. 92.

---1990, Carboniferous and Permian island-arc deposits of the eastern Klamath terrane, California, in Harwood, D.S., and Miller, M.M., eds., Paleozoic and early Mesozoic paleogeographic relations; Sierra Nevada, Klamath Mountains, and related terranes; Geological Society of America Special Paper 255, p. 193-200.

---1993, Carbonate bank sedimentation in a volcaniclastic arc setting; lower Carboniferous limestones of the eastern Klamath Terrane, California: Journal of Sedimentary Petrology, v. 63, no. 5, p. 966-973.

---1993, Permian carbonate platform development in an island-arc setting, Eastern Klamath Terrane, California: Journal of Geology, v. 101, p. 659-666.

---1994, Evolution of Carboniferous to Lower Permian biostromal communities in the Eastern Klamath terrane, California: Geological Society of America, Abstracts with Programs, v. 26, no. 7, p. 426.

Watkins, R., and Bergk-Hall, K., 1991, Progradational development of a Lower Permian carbonate platform, eastern Klamath Mountains, California: Geological Society of America, Abstracts with Programs, v. 23, no. 2, p. 108.

Watkins, R., and Flory, R.A., 1986, Island arc sedimentation in the Middle Devonian Kennett 
Formation, eastern Klamath Mountains, California: Journal of Geology, v. 94, no. 5, p. 753-761.

Watkins, R., and Stensrud, H.L., 1983, Age of sulfide ores in the West Shasta and East Shasta districts, Klamath Mountains, California: Economic Geology, v. 78, p. 340-343.

Watkins, R., and Wilson, E.C., 1989, Paleoecologic and biogeographic significance of the biostromal organism Palaeoaplysina in the Lower Permian McCloud Limestone, Eastern KLamath Mountains, California: Palaios, v. 4, p. 181-192.

Watkins, R., Wilson, E.C., and Hanger, R.A., 1989, Carboniferous and Permian biogeography of the Eastern Klamath terrane, California: Geological Society of America, Abstracts with Programs, v. 21, no. 5, p. 156.

Watson, C.B., 1909, Prehistoric Siskiyou Island and Marble Halls of Oregon: 147 p., Copyright January 4, 1909, by C.B. Watson, Private publication.

Watts, W.L., 1892, Del Norte County, in 11th Report of the State Mineralogist: California State Mining Bureau, p. 195-199.

---1893, Mineral springs in Siskiyou County, in 11th Report of the State Mineralogist: California State Mining Bureau, p. 449-452.

Weathers, M.S., 1976, Geology, petrography and origin of josephinite: Cornell University, Ithaca, N. Y., M.S. thesis.

Weber, F.H., Jr., and Matthews, R.A., 1967, Prospecting for barite in northern Shasta County: California Division of Mines and Geology Mineral Information Service, v. 20, no. 9, p. 107-114.

Wells, F.G., 1933, Notes on the Chieftain and Continental Mines, Douglas County, Oregon: U.S. Geological Survey Bulletin 830, p. 57-62.

---1940, Preliminary geologic map of the Grants Pass quadrangle: Oregon Department of Geology and Mineral Industries, scale 1:96,000.

---1955, Preliminary geologic map of southwestern Oregon west of meridian $122^{\circ}$ west, and south of parallel $43^{\circ}$ north: U.S. Geological Survey Mineral Investigations Field Studies Map MF 38, scale $1: 250,000$.

---1956, Geology of the Medford quadrangle, Oregon-California: U.S. Geological Survey Geological Quadrangle Map GQ 89, scale 1:96,000.

Wells, F.G., and others, 1939, Preliminary geologic map of the Medford quadrangle, Oregon: Oregon Department Geology and Mineral Industries Map Series, scale 1:96,000.

Wells, F.G., and Cater, F.W., Jr., 1950, Chromite deposits of Siskiyou County, California, Chapter 2 in Pt. 1 of Geological investigations of chromite in California: California Division of Mines Bulletin 134, p. 77-127.

Wells, F.G., Cater, F.W., Jr., and Rynearson, G. A., 1946, Chromite deposits of Del Norte County, California, Chapter 1 of Klamath Mountains, Pt. 1 of Geological investigations of chromite in California: California Division of Mines Bulletin 134, 76 p.

Wells, F.G., and Hawkes, H.E., 1965, Chromite deposits of Shasta, Tehama, Trinity, and Humboldt Counties, California, in Geological investigations of chromite in California: California Division of Mines and Geology Bulletin 134, pt. 1, no. 3, p. 130-191.

Wells, F.G., and Hotz, P.E., 1941, Mesozoic volcanic series in southwest Oregon: Geological Society of America Bulletin, v. 52, no. 12, pt. 2, p. 1937-1938.

Wells, F.G., Hotz, P.E., and Cater, F.W., 1948, Preliminary geologic map of the Kerby quadrangle, Oregon: Oregon department of Geology and Mineral Industries, scale 1/96,000.

---1949, Preliminary description of the geology of the Kerby quadrangle, Oregon: Oregon Department of Geology and Mineral Industries Bulletin 40, 23 p.

Wells, F.G., Page, L.R., and James, H.L., 1940, Chromite deposits in the Sourdough area, Curry County, and Briggs Creek area, Josephine County, Oregon: U.S. Geological Survey Bulletin 922-P, p. iv, 461-496.

Wells, F.G., and Peck, D.L., 1961, Geologic map of Oregon west of the 121st meridian: U.S. Geological Survey Miscellaneous Map I-325, scale 1:500,000.

Wells, F.G., Smith, C.T., Rynearson, G.A., and Livermore, J.S., 1949, Chromite deposits near Seiad and McGuffy Creeks, Siskiyou County, California: U.S. Geological Survey Bulletin 948-B, p. 19-62.

Wells, F.G., and Walker, G.W., 1953, Geologic map of the Galice quadrangle, Oregon: U.S. Geological Survey Geological Quadrangle Map GQ-25, scale 1:62,500.

Wells, F.G., Walker, G.W., and McIntyre, J.M., 195l, Pre-Cretaceous stratigraphy of the northern Klamath Mountains (Oregon): Geological Society of America Bulletin, v. 62, no. 12, pt. 2, p. 1514.

Wells, F.G., Walker, G.W., and Merriam, C.W., 1959, Upper Ordovician(?) and Upper Silurian 
formations of the northern Klamath Mountains, California: Geological Society of America Bulletin, v. 70, no. 5, p. 645-649.

Wells, F.G., and Waters, A.C., 1933, Basic igneous rocks of the Roseburg quadrangle, Oregon: Geological Society of America Bulletin, v. 44, pt. 1, p. 107-108.

---1934, Quicksilver deposits of southwestern Oregon: U.S. Geological Survey Bulletin 850, 58 p.

Welsh, J.L., 1978, Emplacement of ultramafic rocks and metamorphism in the Marble Mountains area of the Klamath Mountains: Geological Society of America, Abstracts with Programs, v. 10, no. 3, p. 153.

---1979, Antigorite-chlorite relationships in the Marble Mountains, California; implications for the MgO-SiO2-Al2O3-H2O system: Geological Society of America, Abstracts with Programs, v. 11, no. 7, p. 538.

---1982, Structure, petrology, and metamorphism of the Marble Mountains area, Siskiyou County, California: Madison, University of Wisconsin, Ph.D. dissertation, $250 \mathrm{p}$.

Wemple, E.M., 1906, New cestraciont teeth from the west-American Triassic: California University, Publications Geological Science, v. 5, no. 4, p. 71-73.

Western Geophysical Company of America, 1981, Airborne gamma-ray spectrometer and magnetometer survey, Redding quadrangle $\left[1^{\circ}\right.$ by $2^{\circ}$ sheet]: U.S. Department of Energy, National Uranium Resource Evaluation Program, GJBX-411(81) and GJM-498.

---1981, Airborne gamma-ray spectrometer and magnetometer survey, Weed quadrangle $\left[1^{\circ}\right.$ by $2^{\circ}$ sheet]: U.S. Department of Energy, National Uranium Resource Evaluation Program, GJBX-391(81) and GJM-497.

---1981, Airborne gamma-ray spectrometer and magnetometer survey, Medford quadrangle $\left[1^{\circ}\right.$ by $2^{\circ}$ sheet]: U.S. Department of Energy, National Uranium Resource Evaluation Program, GJBX-384(81) and GJM-496.

Westman, B.J., 1947, Silurian of the Klamath Mountains Province, California: Geological Society of America Bulletin, v. 58, no. 12, pt. 2, p. 1263.

Wetencamp, J.A., Christman, N., and Giaramita, M.J., 2003, Field, petrographic, and geochemical variation in the rocks previously mapped as Pearse Peak diorite, Elk River, southern coastal Oregon: Geological Society of America, Abstracts with Programs, v. 35, no. 4, p. 17.

Wetzstein, E.E., 1986, Sedimentology and tectonic significance of a Cretaceous conglomerate in the eastern Klamath Mountains, California: Lincoln, University of Nebraska, M.Sc. thesis, 46 p.

Wetzstein, E.E., Lindsley-Griffin, N., Jameossanaie, A., and Griffin, J. R., 1986, New Cretaceous paleogeographic reconstruction for the eastern Klamath Mountains, California: Geological Society of America, Abstracts with Programs, v. 18, no. 2, p. 198.

Wheeler, H.E., 1933, Fusulinids of the McCloud and Nosoni formations of northern California: Geological Society of America Bulletin, v. 44, pt. 1, p. 218.

---1935, New trilobite species from the Anthracolithic of northern California: San Diego Society of Natural History Transactions, v. 8, no. 8, p. 49-52; also abs. in Geological Society of America Proceedings 1934, p. 836, June 1935.

---1935, The fauna and correlation of the McCloud Limestone of northern California: Stanford University Bulletin, 6th series, no. 18?, Dissertation Abstracts v. 10, no. ?, p. 83-85; also in Geological Society of America Proceedings 1935, p. 409, June, 1936.

---1939, Age of the Dekkas volcanic rocks of the Klamath Mountains: Geological Society of America Bulletin, v. 50, no. 12, pt. 2, p. 1962.

---1940, Permian volcanism in western North America, in Pacific Science Congress, 6th, Berkeley, California, 1940, Proceedings: California University Press, v. 1, p. 369-376.

White, D.J., and Wolfe, H.D., 1950, Report of reconnaissance of the area from Panther Butte to Tellurium Peak, Douglas County, Oregon: Ore Bin, v. 12, no. 12, p. 71-76.

White, J.R., Jr., 1939, Almeda mine: Seattle, University of Washington, B.S. thesis, 154 p.

Whitebread, J.A., 1993, A lithologic comparison of driller's well logs and field mapping in the analysis of groundwater availability in south central Jackson County, Oregon: Geological Society of America Abstracts with Programs, v. 25, no. 5, p. 163.

Whitney, G., 1976, Clay mineralogy of early-stage weathering products of ultramafic bedrock in alpine zones: Geological Society of America, Abstracts with Programs, v. 8, no. 4, p. 518.

Whitney, J.D., 1865, The northern counties--Shasta, Tehama, Siskiyou, Del Norte, and Trinity, in Geology, v. 1, Report of progress and synopsis of the field work from 1860 to 1864: Geological Survey of California, p. 316-363. 
Whittington, C.L., Grimes, D.J., and Leinz, R.W., 1985, Map showing abundance and distribution of copper in oxide residues and sieved fractions of stream-sediment samples, Medford 1 by 2 quadrangle, Oregon-California: U.S. Geological Survey, Miscellaneous Field Studies Map MF-1383-G, scale 1:250,000.

---1985, Map showing abundance and distribution of silver in stream-sediment samples, Medford 1 by 2 quadrangle, Oregon-California: U. S. Geological Survey, Miscellaneous Field Studies Map MF-1383-H, scale 1:250,000.

---1985, Map showing abundance and distribution of chromium in stream-sediment samples, Medford 1 by 2 quadrangle, Oregon-California: U.S. Geological Survey, Miscellaneous Field Studies Map MF-1383-I, scale 1:250,000.

Whittington, C.L., Grimes, D.J., and Peterson, J.A., 1984, Spectrographic and chemical analyses of rock and soil samples from the Medford $1^{\circ}$ by $2^{\circ}$ quadrangle, Oregon-California: U.S. Geological Survey Open-File Report 83-344, 218 p., with map, scale 1:250,000.

Whittington, C.L., Leinz, R.W., and Speckman, W.S., 1984, Analytical results of stream-sediment samples from the Medford $1^{\circ}$ by $2^{\circ}$ quadrangle, Oregon-California: U.S. Geological Survey, Open-File Report 83-0349, 142 p., with map, scale 1:250,000.

Whittington, C.L., Leinz, R.W., and Grimes, D.J., 1985, Map showing abundance and distribution of arsenic in oxide residues of stream-sediment samples, Medford 1 by 2 quadrangle, Oregon-California: U.S. Geological Survey, Miscellaneous Field Studies Map MF-1383-J, scale $1: 250,000$.

---1985, Map showing abundance and distribution of mercury in rocks samples, Medford 1 by $2^{\circ}$ quadrangle, Oregon-California: U.S. Geological Survey, Miscellaneous Field Studies Map MF-1383-K, scale 1:250,000.

Widmier, J.M., 1963, Mesozoic stratigraphy of the west-central Klamath Province--A study of eugeosynclinal sedimentation: Madison, Wisconsin University, Ph.D. dissertation, $141 \mathrm{p}$.

Wiebelt, F. J., and Smith, M.C., 1959, A reconnaissance of asbestos deposits in the serpentine belt of northern California: U.S. Bureau of Mines Information Circular 7860, iv, 52 p.

Wilde, G.L., 1971, Phylogeny of Pseudofusulinella and its bearing on Early Permian stratigraphy: in Paleozoic perspectives; a paleontological tribute to G. Arthur Cooper: Smithsonian Contributons to Paleobiology, no. 3, p. 363-379.

Wiley, T.J., and Hladky, F.R., 1992, Geologic mapping in the Medford area, Jackson County, Oregon: Geological Society of America, Abstracts with Programs, v. 24, no. 5, p. 90.

Williams, H., 1949, Geology of the Macdoel quadrangle: California Division of Mines and Geology Bulletin 151, p. 7-60.

Williams, I.A., 1920, The Oregon caves; remarkable "marble halls" of Josephine County: Natural History, v. 20, no. 4, p. 397-405.

Williams, J.W., Wolfe, M.D, and Borum, J.D., 1982, Timber harvesting, geomorphic zones, and slope instability in the Klamath and Coast Range provinces of Northwestern California: Geological Society of America, Abstracts with Programs, v. 14, no. 4, p. 245.

Willse, K., Metcalf, R.V., and Wallin, E.T., 1998, Emplacement and petrogenesis of the Lower Silurian Bonanza King mafic intrusive complex, Trinity terrane, northern California: Geological Society of America, Abstracts with Programs, v. 30, no. 5, p. 70.

Wilson, E.C., 1967, Corals and other significant fossils from the Permian McCloud limestone of northern California: Berkeley, California University, Ph.D. dissertation, 306 p.

---1967, Primary type-material of the Early Permian archaeogastropod Omphalotrochus whitneyi (Meek, 1864): Journal of Paleontology, v. 41, no. 5, p. 1113-1115.

---1982, Wolfcampian rugose and tabulate corals (Coelenterata: Anthozoa) from the Lower Permian McCloud Limestone in northern California: Natural History Museum of Los Angeles County, California, Contributions in Science, no. 337, 90 p.

---1984, Stratigraphic range extensions and coral province affiliations of stony corals in the Lower Permian McCloud Limestone of California: Paleontographica Americana, v. 54, p. 437.

---1985, Rugose corals (Coelenterata, Anthozoa) from the Lower Permian McCloud Limestone at Tombstone Mountain, northern California: Natural History Museum of Los Angeles County, California, Contributions in Science, no. 366, 11 p.

Wilson, E.C., and Watkins, R., 1988, The biostrome-forming organism Palaeoaplysina from the Lower Permian McCloud Limestone of northern California: Geological Society of America, Abstracts with Programs, v. 20, no. 3, p. 243. 
Wilson, J.S., 1854, On the gold regions of California: Geological Society of London, Quarterly Journal, QJ 10, p. 308-321.

Wilson, K.M., Hay, W.W., and Wold, C.N., 1991, Mesozoic evolution of exotic terranes and marginal seas, western North America: Marine Geology, v. 102, p. 311-361.

Winchell, A.N., 1914, Petrology and mineral resources of Jackson and Josephine Counties, Oregon: Oregon Bureau Mines and Geology, Mineral Resources of Oregon, v. 1, no. 5, 265 p.

Wisehart, R.M., and Wagner, J.R., 1973, Slope stability and engineering consequences of a stream capture, Bluff Creek, northern California: Annual Highway Geological Symposium, Proceedings, no. 24, p. 25-35.

Wise, J.P., 1969, Geology and petrology of a portion of the Jurassic Galice Formation, Babyfoot Lake area, southwestern Oregon: Pocatello, Idaho State University, M.S. thesis, 108 p.

Witte, D.M., 1977, Geology of the massive sulfide deposits of the Silver Peak District, Douglas County, Oregon: Stanford University, Stanford, California, M.S. thesis, 75 p.

Wolff, J., 1981, Battle Creek Caves \#1 \& \#2, Siskiyou Co., Calif.: California Caver, v. 32, no. 4, p. 5560.

Wood, B.L., 1971, Structure and relationships of Late Mesozoic schists of NW California and SW Oregon: New Zealand Journal of Geology and Geophysics, v. 14, no. 1, p. 219-239.

Wood, R.A., 1987, Geology and geochemistry of the Almeda mine, Josephine County, Oregon: Los Angeles, California State University, M.Sc. thesis, 237 pp.

Woods, M.C., 1976, Pleistocene glaciation in Canyon Creek area, Trinity Alps, California: California Division of Mines and Geology, California Geology, v. 29, no. 5, p. 109-113.

--- 1988, Ice age geomorphology in the Klamath Mountains: A photo essay: California Geology, v. 41, no. 12, p. 273-275.

Works Project Administratiion, 1951, Oregon--End of the trail: Binfords and Mort, Portland, American Guide Series, Revised edition with added material by Howard McKinley Corning.

Worrall, D.M., 1979, Evolution of the Franciscan-Klamath-Great Valley junction, northern California Coast Ranges: Geological Society of America, Abstracts with Programs, v. 11, no. 3, p. 136.

---1979, Geology of the South Yolla Bolly area, northern California, and its tectonic implications: Austin, Texas University, Ph.D dissertation, $292 \mathrm{p}$.

Wright, J.E., 1979, Tectonic correlation between the south-central Klamath Mountains and Sierra Nevada foothill belt: Geological Society of America, Abstracts with Programs, v. 11, no. 3, p. 136.

---1980, Paleotectonic setting of the Hayfork terrane, Klamath Mountains, northern California: Geological Society of America, Abstracts with Programs, v. 12, no. 3, p. 160.

---1981, Geology and U-Pb geochronology of the Western Paleozoic and Triassic Subprovince, Klamath Mountains, northern California: California University, Santa Barbara, Ph.D. dissertation, 300 p.

---1982, Permo-Triassic accretionary subduction complex, southwestern Klamath Mountains, northern California: Journal of Geophysical Research, v. 87, no. B5, p. 3805-3818.

Wright, J.E., and Fahan, M.R., 1988, An expanded view of Jurassic orogenesis in the western United States cordillera: Middle Jurassic (pre-Nevadan) regional metamorphism and thrust faulting within an active arc environment, Klamath Mountains, California: Geological Society of America Bulletin, v. 100, p. 859-876.

Wright, J.E., and Miller, E.L., 1986, An expanded view of Jurassic orogenesis for the western U.S. cordillera: Geological Society of America, Abstracts with Programs, v. 18, no. 2, p. 201.

Wright, J.E., and Sharp, W.D., 1981, The implication of regional tectonic correlations between the Klamath Mountains-Sierra Nevada provinces for the Late Paleozoic to Middle mesozoic tectonic evolution of western North America: Geological Society of America Abstracts with Programs, v. 13, no. 7, p. 585.

---1982, Mafic-ultramafic intrusive complexes of the Klamath-Sierran region, California; remnants of a Middle Jurassic arc complex: Geological Society of America, Abstracts with Programs, v. 14, no. 4, p. 245-246.

Wright, J.E., and Wyld, S.J., 1985, Multi-stage serpentinite matrix melange development: Rattlesnake Creek terrane, southwestern Klamath Mountains: Geological Society of America, Abstracts with Programs, v. 17, no. 6, p. 419.

---1986, Significance of xenocrystic Precambrian zircon contained within the southern continuation of the Josephine ophiolite: Devils Elbow ophiolite remnant, Klamath Mountains, northern California: Geology, v. 14, p. 671-674.

---1994, The Rattlesnake Creek terrane, Klamath Mountains, California: An early Mesozoic volcanic 
arc and its basement of tectonically disrupted oceanic crust: Geological Society of America Bull.,v. 106, p. 1033-1056.

Wyld, S.J., 1985, Geology of the Western Jurassic belt, South Fork Trinity River area, Klamath Mountains, California: Berkeley, University of California, M.Sc. thesis, 168 p.

Wyld, S.J., and Wright, J.E., 1985, The Late Jurassic Galice basin and its ophiolitic and serpentinite basement, Klamath Mtns., California: Geological Society of America, Abstracts with Programs, v. 17 , no. 6, p. 419.

---1986, The significance of xenocrystic Precambrian zircon in the southern continuation of the Josephine ophiolite, Klamath Mountains, northern California: Geological Society of America, Abstracts with Programs, v. 18, no. 2, p. 202.

---1988, The Devils Elbow ophiolite remnant and overlying Galice Formation: New constraints on the Middle to Late Jurassic evolution of the Klamath Mountains, California: Geological Society of America Bulletin, v. 100, no. 1, p. 29-44.

---1993, Is the Rattlesnake Creek terrane out of place with respect to other terranes in the Klamath Mountains, CA?: Geological Society of America, Abstracts with Programs, v. 25, no. 5, p. 167.

Wynn, J.C., and Hasbrouck, W.P., 1980, Geophysical studies of chromite deposits in the Josephine ultramafic complex of Northwest California and Southwest Oregon: U.S. Geological Survey, Open-File Report 80-936, 47 p.

---1984, Geophysical studies of chromite deposits in the Josephine Peridotite of northwestern California and southwestern Oregon: U.S. Geological Survey Bulletin 1548, p. 64-86.

Yale, C.G., 1899, The mineral industry of California, in California mines and minerals: California Miner's Association, Souvenir edition, Louis Roesch Company, San Francisco, California, p. 1-56.

Yancey, T.E., and Hanger, R.A., 1985, Biotic replacement along a ramp gradient on a Permian island arc, McCloud Fm., California: Geological Society of America, Abstracts with Programs, v. 17, no. 7, p. 756.

---1986, Endemisim of Early Permian invertebrates, with implications for paleogeographic position of the Eastern Klamath terrane: Geological Society of America Abstracts with Programs, v. 18, no. 6.

---1986, Comment on"Volcaniclastic and carbonate sedimentation in late Paleozoic island-arc deposits, eastern Klamath Mountains, California": Geology, v. 14, no. 6, p. 538-539.

Young, J.C., 1974, Geologic road log along U. S. Highway 299, between Gray Falls Campground and Berry Summit, Trinity and Humboldt Counties, California, in D. F. R. McGeary, ed., Geologic guide to the southern Klamath Mountains: Geological Society of Sacramento, Annual Field Trip Guidebook, p. 116-120.

---1978, Geology of the Willow Creek quadrangle, Humboldt and Trinity Counties, California: California Division of Mines and Geology Map Sheet 31, Scale 1:62,500, with text $16 \mathrm{p}$.

Young, L.G., 1989, Aeromagnetic map of the Redding $1^{\circ}$ by $2^{\circ}$ quadrangle, California: California Division of Mines and Geology Open-File Report 89-02, scale 1:250,000.

Youngberg, E.A., 1974, Mines and prospects of the Mount Reuben mining district, Josephine County, Oregon: Oregon Department of Geology and Mineral Industries Bulletin 34, 35 p.

Yule, J.D., 1996, Geologic and tectonic evolution of Jurassic marginal ocean basin lithosphere, Klamath Mountains, Oregon: Pasadena, California Institute of Technology, Ph.D. thesis, 308 p.

Yule, J.D., and Saleeby, J.B., 1991, Older oceanic crust and a protracted fracture zone assemblage from beneath the Josephine ophiolite, Illinois River area, southwestern Oregon: Geological Society of America, Abstracts with Programs, v. 23, no. 2, p. 112.

---1993, Highly extended oceanic lithosphere: The basement and wallrocks for the Late Jurassic RogueChetco oceanic arc, Oregon Klamath Mountains: Geological Society of America, Abstracts with Programs, v. 25, no. 5, p. 169.

Yule, J.D., Saleeby, J.B., and Barnes, C.G., 1994, Geochemistry of Rattlesnake Creek terrane fragments contained within the Western Jurassic belt, Oregon Klamath Mountains: Geological Society of America, Abstracts with Programs, v. 26, no. 2, p. 106-107.

---1996, The 175-135 Ma plutons of the Klamath Mountains province reinterpreted as a single oceanic arc batholithic system: Geological Society of America, Abstracts with Programs, v. 28, no. 5, p. 128.

Yule, J.D., Saleeby, J.B., Jones, D.L., and Silk, M., 1992, Correlation of basement terranes across the Late Jurassic Josephine inter-arc basin, southwestern Oregon and northern California: Geological Society of America, Abstracts with Programs, v. 24, no. 5, p. 93.

Zdanowicz, T., 1971, The folded Mallethead thrust, eastern Klamath Mountains, California: 
Geological Society of America, abstracts with Programs, v. 3, no. 2, p. 223.

---1972, Stratigraphy and structure of the Horseshoe Gulch area, Etna and China Mountain quadrangles, California: Corvallis, Oregon State University, M.S. thesis, 88 p.

Zierenberg, R.A., Shanks, W.C. III, Seyfried, W.W., Jr., Koski, R.A. and Strickler, M.D., 1988, Mineralization, alteration, and hydrothermal metamorphism of the ophiolite-hosted Turner-Albright sulfide deposits, southwestern Oregon: Journal of Geophysical Research, v. 93, p. 4657-4674.

Zucca, J.J., Fuis, G.S., Milkereit, B., Mooney, W.D., and Catchings, R.D., 1986, Crustal structure of northern California: Journal of Geophysical Research, v. 91, no. B7, p. 7359-7382. 


\section{TOPICAL LISTING OF REFERENCES}

\section{HISTORY OF REGION}

Abbot, 1857, Explorations for railroad route, Sacramento Valley to Columbia River

Baldwin, 1980, Pioneer geologists, southwestern Oregon

Block, 1982, Whitney survey of California, 1860-1874

Boyle, 1974, History of communities along highway 299

Condon, 1902, The two islands

Condon, 1910, Revision of "The two Islands"

Cox, 1858, Annals of Trinity County

Dana, 1849, Upper California, United States Exploring Expedition

Dana, 1849, Oregon and northern California, United States Exploring Expedition

Diller, 1891, Report of Mr. Diller, Cascade Division

Diller, 1884, Geologic work in northern California and Oregon

Farquhar, 1974, Up and down California in 1860-1864

Lanphere and Irwin, 1987, In search of the Abrams Post Office

Lawson, 1941, Memorial to Oscar H. Hershey

Stumpf, 1979, Gold mining in Siskiyou County, 1850-1900

Shurkin, 1983, Stanford geology in Klamath Mountains

Walsh, 1994, Gold at Reading's Bar, Clear Creek, Shasta County

Whitney, 1865, Shasta, Tehama, Siskiyou, Del Norte, and Trinity Counties

Works Project Administratiion, 1951, Oregon--End of the trail

\section{PHYSIOGRAPHY}

Anderson, 1902, Physiographic features, Klamath Mountains

Anderson, 1903, Physiography and geology, Siskiyou Range

Baldwin, 1993, Geomorphic surfaces, Klamath Mountains, California and Oregon

Baldwin and De La Fuente, 1987, Landslide deposits, central Klamath and south Cascade Mountains

Baldwin and De La Fuente, 1989, Remnant planar landforms, Klamath Mountains

Baldwin and Ricks, 1993, Geomorphic surfaces, Klamath Mountains, California and Oregon

De La Fuente and others, 1993, Geomorphic terranes, central Klamath Mountains

Dicken, 1952, Rogue River Country of Oregon

Diller, 1894, Revolution in topography since the auriferous gravel period

Diller, 1894, Tertiary revolution in topography of Pacific Coast

Diller, 1902, Topographic development of Klamath Mountains

Hershey, 1902, Supposed Tertiary peneplain, Klamath region

Hershey, 1903, Sierran valleys, Klamath region

Hershey, 1903, Certain river terraces, Klamath region

Hershey, 1904, River terraces of Orleans Basin

Hicks, 1974, China slide

Hinds, 1935, Late Cenozoic history, southern Klamath Mountains

Hinds, 1952, Evolution of California landscape

Jenkins, 1943, Geomorphic provinces of California

Lehre, 1980, Effect of organic debris on morphology

Maxson, 1932, Geomorphic features, northwesternmost California

McHuron and Rice, 1988, Landslides versus river terraces, Gasquet Mountain

Parsons, 1978, Soil-geomorphology relations in mountains of Oregon

Short, 1987, Terranes as terrains

\section{FLOODS}

Helley and LaMarche, 1972, December 1964, a 400-year flood

Helley and LaMarche, 1973, Historic flood, geological and botanical evidence

Stewart and LaMarche, 1967, Erosion and deposition, flood of December 1964, Coffee Creek, Trinity County

\section{GLACIATION}

Aune, 1970, Glaciation in Mt. Shasta-Castle Crags 
Bevis, 1989, Dating techniques and glacial geology, upper Clear Creek watershed, Siskiyou Mountains Hershey, 1900, Ancient alpine glaciers, Sierra Costa Mountains

Hershey, 1903, Evidence of two glacial stages, Klamath Mountains

Hershey, 1903, Relation between river terraces and glacial series

Lee, 1972, Glaciation of Red Mountain area

Sharp, 1960, Pleistocene glaciation, Trinity Alps

Wahrhaftig and Birman 1965, Quaternary of Pacific mountain system

Woods, 1976, Pleistocene glaciation, Canyon Creek area, Trinity Alps

Woods, 1988, Ice age geomorphology, Klamath Mountains

CAVES

Barnes, 1983, Geology of Big Foot cave, Marble Mountains

Bosted, 1990, Cave exploration and mapping in the 1980's

Bosted, 1989, Exstream cave

Bosted and Richardson, 1989, Stairstep Dome cave

Contor, 1963, Underworld of Oregon Caves National Monument

Davidson, 1900, Register of mines and minerals, Siskiyou County

Erftenbeck, 1948, Northern California

Fidler, 1922, First attempt at exploration of Oregon Caves

Furlong, 1905, Preptoceras, a new ungulate from Samwel Cave

Furlong, 1906, Exploration of Samwel Cave

Groo, 1982, Speleogenesis in Marble Cave, Trinity County

Halliday, 1962, Caves of California

Halliday, 1963, Use of Oregon Cave as fallout shelter

Halliday, 1963, Speleological considerations of Oregon Cave

Halliday, 1967, Geology of Oregon Cave

Halliday, 1969, Oregon Cave

Halliday and Walsh, 1976, Oregon caves; discovery \& exploration

Knutson, 1981, Black Mountain, Marble Mountain Wilderness

Knutson, 1982, Toughest caves in the west

Knutson, 1985, Marble Mountains--1985

Knutson, 1987, Marble Mountains--Recent explorations

Knutson, 1989, Marble Valley project; 1988 field log

Knutson, 1989, Rainy Cave

Larson and Larson, 1976, Caves of Oregon

Merriam, 1906, Recent cave explorations in California

Merriam, 1927, Cave of the magic pool

Murphy, 1994, No Name caves, southwestern Oregon

Richardson and Bosted, 1989, Sunbeam Cave

Sims, 1979, Alpine karst, Marble Mountains

Sims, 1984, Marble Mountains: Organization of cave survey

Sims and Knutson, 1983, Cave exploration, Klamath Mountains

Sinclair, 1904, Exploration of Potter Creek cave

Sugget, 1983, Biological survey, Marble Valley caves

Watson, 1909, Prehistoric Siskiyou Island and Marble Halls

Williams, 1920, Oregon caves; remarkable "marble halls"

Wolff, 1981, Battle Creek Caves, Siskiyou Co.

MINERAL SPRINGS

Barnes and others, 1975, Springs rich in carbon dioxide or chloride

Waring, 1915, Springs of California

Watts, 1893, Mineral springs in Siskiyou County

WATERSHED AND GROUNDWATER INVESTIGATIONS

Buer and James, 1979, South Fork Trinity River watershed erosion

Buer, Scott, and James, 1979, South Fork Trinity River watershed

De La Fuente and Haessig, 1992, Sediment budget, Salmon River basin 
Lund, 1974, Erosion and silting, Ashland Watershed

Mack, 1982, Chemistry of ground waters, Grants Pass Batholith

Mack, 1982, Geology, ground water chemistry, and hydrogeology of Murphy area

Mack, 1958, Geology and ground-water features, Scott Valley

Mack, 1958, Geology and ground-water resources, Scott and Shasta Valleys

Mack, 1960, Geology and ground-water features, Shasta Valley

Olmsted, 1956, Ground-water conditions, northwestern California

Prokopovich, 1966, Spring Creek and its delta

Prokopovich, 1975, Calcareous deposits in Clear Creek tunnel

Serr, 1972, Sedimentation aspects of water resources

Whitebread, 1993, Comparison of driller's well logs and field mapping, Jackson County

WILDERNESS, ROADLESS, AND RARE II AREAS

Adrian and others, 1983, Chemical analyses of samples, Condrey Mountain area

Adrian and others, 1983, Chemical analyses of samples, Orleans Mountain area

Barnard and others, 1981, Serpentine minerals and magnetic susceptibility, Kalmiopsis Wilderness

Blake and Peters, 1983, Mineral resource potential, Weaver Bally area

Blake and Peters, 1984, Weaver Bally area

Carlson and others, 1982, Geochemical characteristics of rocks, Kalmiopsis Wilderness

Coleman and Mayerle, 1984, Condrey Mountain Roadless Area

Coleman and others, 1983, Map of Condrey Mountain Roadless Area

Diggles and others, 1984, Geochemical data for samples from Tunnel Ridge Wilderness Study Area

Diggles and Kennedy, 1986, Geologic and geochemical-anomaly map, Tunnel Ridge Wilderness Study Area

Donato, 1982, Marble Mountain Wilderness area

Donato and Hale, 1984, Marble Mountain Wilderness

Donato and Linne, 1984, Orleans Mountain Roadless Area

Donato and others, 1983, Mineral resource, Orleans Mountain Roadless Area

Donato and others, 1983, Map of Orleans Mountain Roadless area

Donato and others, 1982, Map of Marble Mountain Wilderness

Donato and others, 1983, Mineral resource, Marble Mountain Wilderness

Gray and Hamilton, 1983, North Fork Smith River Roadless Area

Gray and others, 1983, Mineral resource, North Fork Smith River Roadless Areas

Gray and Miller, 1983, Wild Rogue Wilderness, Oregon

Gray and Peterson, 1982, Geochemical analyses, Wild Rogue wilderness area

Gray and others, 1982, Map of Wild Rogue Wilderness

Gray and others, 1982, Mineral resource map, Wild Rogue Wilderness

Hamilton and others, 1983, Mineral investigation, North Fork Smith RARE II Area

Hotz and Thurber, 1984, Salmon-Trinity Wilderness

Hotz and others, 1974, Mineral resources, additions to Salmon-Trinity Alps Primitive Area

Hotz and others, 1972, Mineral resources, Salmon-Trinity Alps primitive area

Huber and Cather, 1984, Fisher Gulch Roadless Area

Huber and Cather, 1984, Lake Eleanor Roadless Area

Huber and Nelson, 1983, Mineral resource, Granite Peak Roadless Area

Huber and Thurber, 1984, Granite Peak Roadless Area

Huber and Stebbins, 1984, Chanchelulla Peak Roadless Area

Huber and others, 1983, Mineral resource, Fisher Gulch Roadless Area

Huber and others, 1983, Mineral resounce, Chanchelulla Roadless Area

Jayko and Blake, 1984, Map of part of Orleans Mountain Roadless Area

Jayko and Marks, 1984, Orleans Mountain Roadless Area

Jayko and others, 1983, Mineral resource, Orleans Mountain Roadless Area

Kennedy and others, 1985, Mineral resource map of Tunnel Ridge Wilderness Study Area

Page and others, 1981, Map of Kalmiopsis Wilderness area

Page and Miller, 1983, Kalmiopsis Wilderness

Peters, 1983, Mineral investigation, Weaver Bally RARE II Area

Peterson and Caress, 1983, Geochemical map, Mount Eddy and Castle Crags Roadless Areas

Peterson and Denton, 1984, Mount Eddy and Castle Crags Roadless Area 
Peterson and others, 1983, Mineral resource, Mount Eddy and Castle Crags Roadless Areas Peterson and others, 1983, Geologic map, Mount Eddy and Castle Crags Roadless Areas Peterson and others, 1983, Geochemical analyses, Mount Eddy and Castle Crags Roadless Areas Peterson and Gray, 1982, Geochemical map, Wild Rogue Wilderness

Ramp and Gray, 1980, Sheeted dikes of Wild Rogue Wilderness

Singer and others, 1983, Mineral resource maps, Medford $1^{\circ}$ by $2^{\circ}$ quadrangle

Smith and Peterson, 1985, Mineral deposits, Medford $1^{\circ}$ by $2^{\circ}$ quadrangle

Smith and others, 1986, Information to accompany geologic, geochemical, geophysical, and mineral resource maps of the Medford $1^{\circ}$ by $2^{\circ}$ quadrangle

Throckmorton and others, 1980, Land classification, Weed $1^{\circ}$ by $2_{\circ}^{\circ}$ quadrangle Whittington and others, 1985, Copper in samples, Medford $1^{\circ}$ by $2_{0}^{\circ}$ quadrangle Whittington and others, 1985, Silver in samples, Medford 1 by 2 quadrangle Whittington and others, 1985, Chromium in samples, Medford 1 by 2 quadrangle

Whittington and others, 1984, Spectrographic and chemical analyses of samples, Medford $1^{\circ}$ by $2^{\circ}$ quadrangle

Whittington and others, 1984, Analytical results of samples, Medford 1 by 2 quadrangle

Whittington and others, 1985, Arsenic in samples, Medford 1 by 2 quadrangle

Whittington and others, 1985, Mercury in samples, Medford 1 by 2 quadrangle

ROAD LOGS, FIELD GUIDES, AND RAFT TRIPS

Aalto, 1989, Preface; evolution of Coast Ranges and Klamath Mountains

Aalto and Harper, 1989, Evolution of Coast Ranges and Klamath Mountains

Alt and Hyndman, 1975, Roadside geology of northern California

Alt and Hyndman, 2000, Roadside geology of northern and central California

Ando and others, 1977, Geologic summary and road log, central Klamath Mountains

Aune, 1970, Trip to Castle Crags

Bald, J.F., 1991, Castle Crags wilderness, a climbers guide

Cashman, 1974, Cross-section, western Paleozoic and Triassic subprovince, Salmon River

D'Allura, 1990, Klamath River, I-5 near Hornbrook to Seiad Valley

Diller and others, 1915, The Shasta route and coast line

Donato, 1992, Geologic guide, Red Mountain to Bald Mountain (May Creek Schist and related rocks)

Evans, 1969, McCloud Limestone in South Gray Rocks area

Goullaud, 1977, Structure and petrology, Trinity mafic-ultramafic complex

Harbaugh, 1974, Geology field guide to northern California

Harper, 1989, Field guide to Josephine ophiolite and island arc complex

Harris, 1978, Klamath River geology, Curley Jack Camp to Ti Bar

Harris, 1979, Geology along Klamath River between Curley Jack Camp and Ti Bar

Hirt, ed., 1999, Across the Klamath/Cascade Frontier

Irwin, 1960, Geology along U.S. Highway 299 between Weaverville and Arcata

Irwin, 1980, The Klamath Mountains

Irwin, 1989, Terranes of the Klamath Mountains

Irwin, 1997, Field guide for a GEOMAR and University of Kiel trip across the accreted terranes

Kays, 1992, Geologic guide, Cow Creek to Red Mountain

Kays and Ferns, 1980, Geologic guide, north-central Klamath Mountains

Kramer, 1977, Geologic guide along Highway 299, Redding to Willow Creek

Lindsley-Griffin and Kramer, 1977, Guidebook to geology of Klamath Mountains

Lindsley-Griffin and Rohr, 1977, Lovers Leap: a geologic puzzle

Lindsley-Griffin and others, 1974, Geology of Lovers Leap Area

Lydon, 1963, A trip in Shasta County

McGeary, 1974, Geologic guide to southern Klamath Mountains

McGeary and others, 1974, Road log, Scott Valley-Lover's Leap-Yreka-Redding

McGeary and others, 1974, Road log, Willow Creek-Somes Bar-Forks of Salmon-Sayers Bar-Etna

Miller, 1989, Late Paleozoic and early Mesozoic evolution of Eastern Klamath terrane, near McCloud Lake

Seyfert, 1974, Sawyers Bar quadrangle

Snoke, 1974, U.S. Highway 299, between Shasta and Gray Falls Campground

Stein, 1984, Field trip to Trinity County 
Young, 1974, U.S. Highway 299, between Gray Falls Campground and Berry Summit

\section{GEOLOGIC MAPS \\ Regional}

Dott, 1971, Geology of southwestern Oregon coast west of 124th meridian

Irwin, 1960, Reconnaissance of the northern Coast Ranges and Klamath Mountains, with summary of mineral resources

Irwin, 1994, Map of Klamath Mountains, California and Oregon

Irwin, 1997, Selected post-Nevadan geologic features of the Klamath Mountains and adjacent areas Jenkins, 1938, Geologic map of California

Jennings, 1977, Geologic map of California

Walker and Macleod, 1991, Map of Oregon

Wells, 1955, Map of southwestern Oregon

Wells and Peck, 1961, Map of Oregon west of 121st meridian

Aalto and others, 1988, Map of Pilot Creek quadrangle

Albers, 1964, French Gulch quadrangle

Albers and others, 1964, French Gulch quadrangle

Baldwin and Hess, 1971, Geology of Powers quadrangle

Blair and others, 1981, Map of parts of Gold Hill, Ruch, Medford, and Talent quadrangles

Blake and others, 1984, Map of Red Bluff 100,000 quadrangle

Blake and others,1999, Geologic map of the Red Bluff 30' X 60' quadrangle

Cashman and others, 1982, Geology of Coyote Peak [15'] quadrangle, Humboldt County

Cater and Wells 1953, Geology and mineral resources, Gasquet quadrangle

Diller, 1898, Description of Roseburg quadrangle

Diller, 1903, Description of Port Orford quadrangle

Diller, 1906, Description of Redding quadrangle

Diller and Kay, 1924, Description of Riddle quadrangle

Donato, 1991, Map of part of May Creek Schist and related rocks

Donato, 1992, Map of Carberry Creek quadrangle

Donato, 1993, Map of Squaw Lakes quadrangle

Fraticelli and others, 1987, Map of Redding 1 X 2 degree quadrangle

Gay and Aune, 1958, Map of California, Alturas Sheet

Hollister and Evans, 1965, Geology of Redding quadrangle

Hotz, 1967, Map of Condrey Mountain quadrangle and parts of Seiad Valley and Hornbrook quadrangles

Hotz, 1974, Map of Yreka quadrangle

Hotz, 1977, Geology of Yreka quadrangle

Hotz, 1978, Map of Yreka quadrangle and parts of Fort Jones, Etna, and China Mountain quadrangles

Irwin, 1963, Map of Weaverville quadrangle

Irwin, 1974, Map of Hayfork quadrangle

Irwin, 1985, Map of Hyampom quadrangle

Irwin and others, 1974, Map of Pickett Peak quadrangle

Irwin and others, 1985, Map of Dubakella Mountain quadrangle

Johnson and Page, 1979, Map of parts of Canyonville, Days Creek, and Glendale quadrangles

Lydon and others, 1960, Map of California, Westwood Sheet

Lydon and Klein, 1969, Southeast quarter of Trinity Lake quadrangle

Moring, 1983, Surficial geologic map, Medford 1 by 2 quadrangle

Murphy and others, 1969, Geology of Ono quadrangle

Page and others, 1977, Map of Wimer quadrangle

Page and others, 1981, Map of Selma quadrangle

Page and others, 1978, Map of Glendale quadrangle

Ramp, 1984, Map of southeast quarter, Pearsoll Peak quadrangle

Ramp and Moring, 1986, Map of Mariel quadrangle

Smith and others, 1982, Map of Medford $1^{\circ} \times 2^{\circ}$ quadrangle

Strand, 1962, Geologic map of California, Redding sheet 
Strand, 1963, Geologic map of California, Weed sheet Wagner and Saucedo, 1988, Map of Weed quadrangle

Wells, 1940, Map of Grants Pass quadrangle

Wells, 1956, Medford quadrangle

Wells and others, 1939, Map of Medford quadrangle

Wells and Walker, 1953, Map of Galice quadrangle

Wells and others, 1948, Map of Kirby quadrangle

Wells and others, 1949, Description of the geology of the Kerby quadrangle

Williams, 1949, Macdoel quadrangle

Young, 1978, Willow Creek quadrangle

Thesis mapping

Ando, 1979, Structural and petrologic analysis, North Fork terrane

Bartley, 1955, East Evans Creek area, Trail quadrangle

Black, 1979, Southeast quarter of Dutchman Butte quadrangle

Blair, 1983, Geology of lower Grider Creek ridge area

Brewer, 1954, Portion of China Mountain quadrangle

Burton, 1982, Geology of Scott Bar Mountains

Cashman, 1979, Geology of Forks of Salmon area

Cashman, 1977, Structure and petrology of part of Duzel Formation

Champ, 1969, Northern part of Dixonville quadrangle

Charlton, 1979, Part of Ironside Mountain quadrangle

Cornelius, 1984, Geology of Rock Creek Butte

Cornell, 1971, Northwest quarter of Canyonville quadrangle

Cox, 1956, Geology of Helena quadrangle

Curtis, 1980, Portions of Bonanza King and Schell Mountain quadrangles

Davis, 1961, Geology of Coffee Creek area

Elphic, 1969, Southern one-third of Glide quadrangle

Fraticelli, 1984, Portions of Project City and Bella Vista

Gay, 1949, Geology of Upper Coffee Creek, Etna quadrangle

Hicks, 1964, Southwest quarter of Roseburg quadrangle

Hilton, 1975, Geology of Ingot-Round Mountain area

Hixson, 1965, Southwest quarter of Dixonville quadrangle

Holdaway, 1963, Parts of northern Coffee Creek and Cecilville quadrangles

Johnson, 1965, Southeastern quarter of Roseburg 15' quadrangle

Kingston, 1985, Geology of northern Lamoine quadrangle

Klein, 1976, Southeastern portion of Happy Camp Quadrangle

Lawson, 1986, Geology of Covington Mill 7.5 minute quadrangle

Lipman, 1962, Geology of southeastern Trinity Alps

Maxson, 1931, Geology of western Siskiyou Mountains

Maytum, 1967, Southeast portion Chanchelulla Peak quadrangle

Mortimer, 1984, Klamath Mountains near Yreka

Nachman, 1976, Duzel Rock area, Yreka quadrangle

Nelson, 1986, Geology and mineralization, Bella Vista-Ingot area

Norman, 1984, Structure and petrology, Summit Valley area

Olson, 1978, Grouse Creek area, China Mountain quadrangle

Petersen, 1982, Geology around Titus Ridge

Porter, 1973, Geology of Facey Rock area, Etna quadrangle

Pratt, 1964, Geology of Marble Mountains area

Quine, 1977, Geology of Lower Chrome Ridge

Rohr, 1972, Lover's Leap area, China Mountain quadrangle

Romey, 1962, Part of Etna quadrangle

Rowland, 1966, Grouse Creek area, South Fork Mountains

Sanborn, 1953, Part of Big Bend quadrangle

Seeley, 1974, Southeastern quarter of Dixonville quadrangle

Seyfert, 1965, Sawyers Bar area

Snoke, 1972, Preston Peak area 
Trexler, 1968, Northwest quarter of Cecilville quadrangle

Welsh, 1982, Marble Mountains area

Worrall, 1979, South Yolla Bolly area

Wyld, 1985, Western Jurassic belt, South Fork Trinity River

Yule, J.D., 1996, Geologic and tectonic evolution, Klamath Mountains, Oregon

Zdanowicz, 1972, Horseshoe Gulch area, Etna and China Mountain quadrangles

AREAL GEOLOGY

Ando and others, 1983, North Fork terrane, Salmon River region

Armstrong, 1975, Cenozoic igneous history of Cordillera north of $42^{\circ} \mathrm{N}$.

Bailey, 1980, Geology of Scott Summit

Baldwin, 1964, Geology of Oregon

Baldwin, 1976, Geology of Oregon

Baldwin and Lent, 1969, Post-Nevadan Mesozoic geology, Klamath Mountains

Baldwin and others, 1968, Post-Nevadan Mesozoic geology, Klamath Mountains

Charlton, 1978, Submarine fan constructed on Rattlesnake Creek ophiolite

Cornelius, 1986, Geology of Rock Creek Butte area

Cox, 1967, Geology of Helena quadrangle

Danielson, 1988, Lithology and geochemistry of French Gulch inlier

Davis and others, 1965, Structure, metamorphism, and plutonism in south-central Klamath Mountains

Diller, 1886, Notes on northern California

Diller, 1896, Klamath Mountains, Oregon

Diller, 1904, Composition and structure of Klamath Mountains

Dole and Baldwin, 1947, Reconnaissance between Almeda and Silver Peak mines

Donato and others, 1981, Northward continuation of Hayfork terrane

Donato and others, 1996, The enigmatic Applegate Group of southwestern Oregon

Dutton, 1891, Crystalline rocks, northern California and southern Oregon

Ernst, 1990, Accretionary terrane in Sawyers Bar area

Ernst, 1997, Geologic map of the Sawyers Bar area_Evolution of an oceanic island arc

Ernst, 1998, Geologic map of the Sawyers Bar area

Fairbanks, 1893, Geology and mineralogy of Shasta County

Goodge, 1986, Relations of Stuart Fork and North Fork terranes

Gorman, 1985, Geology of Rattlesnake Creek terrane

Gray and Petersen, 1982, Northward continuation of Rattlesnake Creek terrane

Haessig, 1989, Field relations and structure of schist of Skookum Gulch

Harden, 1997, The Klamath Mountains: Accreted terranes and a view of the mantle

Harper, 1978, Western Jurassic belt, vicinity of Smith River

Hershey, 1911, Del Norte County geology

Hinds, 1934, Geology of Weaverville district

Irwin, 1966, Geology of Klamath Mountains

Irwin, 1966, Geology of Klamath Mountains province

Irwin, 1975, Pacific Northwest Region

Irwin, 1980, The Klamath Mountains

Irwin and Hotz, 1974, Geologic sketch of Klamath Mountains and Coast Ranges

Irwin and Hotz, 1979, Geology of Douglas-fir region

Irwin and Tatlock, 1955, Northwestern California; a progress report

Koch, 1966, Geology of Port Orford-Gold Beach area

LeRoy, 1993, Reconnaissance of northeast side of Hyampom Valley

Masson, 1949, Geology of Gunsight Peak district

McKee, 1972, Klamath Mountains of Oregon

Norman and others, 1983, Northern extension, Rattlesnake Creek terrane

Norris and Webb, 1990, Klamath Mountains, in Geology of California

O'Brien, 1903, Geology west of Redding

Oesterling and others, 1958, Part of southern Klamath Mountains

Ohr, 1987, Lems Ridge olistostrome

Park-Jones, 1988, Galice Formation

Potter and others, 1977, Lower Paleozoic in eastern Klamath Mountains 
Ramp, 1969, Geology of Klamath Mountains Province

Russell, 1884, Reconnaissance in southern Oregon

Sanborn, 1960, Southwest quarter of Big Bend quadrangle

Smith and Page, 1977, Map of part of Jackson County

Trask, 1855, Geology of the Coast Mountains

Wagner and Saucedo, 1982, Map of Weed Sheet

Wagner, 1988, Del Norte and Siskiyou Counties and portions of Humboldt, Shasta, and Trinity Counties

Wells and others, 1949, Description of Kerby quadrangle

White and Wolfe, 1950, Area from Panther Butte to Tellurium Peak

Wiley and Hladky, 1992, Mapping in Medford area

Wright and Wyld,1994, The Rattlesnake Creek terrane

\section{STRUCTURE}

$\underline{\text { Faults }}$

Baldwin, 1964, Thrust faulting in Roseburg area

Baldwin, 1969, Thrust faulting along lower Rogue River

Baldwin and Lent, 1972, Emplacement of Colebrooke thrust plate

Baldwin and Rud, 1972, Thrusting of Rogue Formation near Marial

Cannat and Boudier, 1986, Chaarriages infra-ophiolitiques et convergence oceanique

Cashman and Cashman, 1996, Evidence for eposidic slip: La Grange fault

Cashman and Elder,1993, Tertiary detachment faulting and mineralization: La Grange fault

Cashman, 1996, La Grange fault revisited: Evidence for regionally-extensive detachment faulting

Cashman and others, 1983, Low-angle thrusting, Rattlesnake Creek terrane

Cashman and others, 1999, Detachment faulting in the Klamath Mountains

Eisbacher, 1983, Devonian-Mississippian sinistral transcurrent faulting along the cratonic margin

Goldstein, 1998, A continuation of the La Grange fault

Gray, 1983, Kinematic analysis of thrust faulting

Gunther, 1905, Fault system, New York mine

Hacker and others, 1992, Synmagmatic fault, central Klamath Mountains

Harper, 1992, Contrasting thrust directions, Josephine-Galice subterrane

Jachens and others, 1986, Subsurface configuration of Orleans fault

Jennings and Saucedo, 1994, Fault activity map of California and adjacent areas, with locations and ages of recent volcanic eruptions

Jones and Harper, 1988, Late Nevadan thrusting, western Klamath Mountains

Klein, 1976, Thrust faulting; origin of schists of Condrey Mountain

Klein, 1977, Thrust plates near Happy Camp

Perttu and Benson, 1980, Canyonville fault; north boundary of Klamath Mountains

Peterson, 1982, Orleans fault near Happy Camp

Pridmore and Frost, 1992 , Detachment faults, California's extended past

Schweickert and Irwin, 1986, Detachment faulting

Schweickert and Irwin, 1989, Extensional faulting, southern Klamath Mountains

Townsend, 1995, Petrology of unusual dacite dikes, La Grange fault

Zdanowicz, 1971, Folded Mallethead thrust

Other, and general

Cashman, 1974, Melange terrane, western Paleozoic and Triassic subprovince

Cashman, 1988, Finite-strain patterns, Nevadan deformation

Davis and others, 1979, Cross section of central Klamath Mountains

Davis and others, 1980, Cross section of central Klamath Mountains: Summary

Donato, 1990, Ductile shear zone, northeastern Klamath Mountains

Fahan and Smith, 1986, Deformed metamorphic minerals from Pigeon Point, western Hayfork terrane

Hershey, 1903, Structure of southern portion of Klamath Mountains

Hintze, 1956, Structural trends in Oregon

Irwin and Dennis, 1979, Structure section across southern Klamath Mountains, Coast ranges, and seaward of Point Delgada

Jones, 1988, Structure of northern Galice Formation

Masson, 2002, Revised geology of the Grey Rocks outlier 
Mortimer and Coleman, 1984, Neogene structural dome

Mortimer and Coleman, 1985, Neogene structural dome

Ohr and others, 1986, Fracture zone origin of Lems Ridge olistostrome

Ramp, 1956, Chrome Ridge area

Rich and Steele, 1974, Structures detected from ERTS-1 satellite imagery

Riddihough and others, 1986, Klamath-Blue Mountain lineament

Roure, 1980, Un profil geologique dans les chaines de l'Ouest americain

Roure and Blanchet, 1983, Transect between Klamath Mountains and Pacific Ocean

Talley, 1976, Redwood Mountain outlier of the South Fork Mountain Schist

\section{METAMORPHISM}

Blueschist

Blake, 1965, Low-grade metamorphic rocks, blueschist facies, Yolla Bolly area

Borns, 1980, Blueschist metamorphism, Yreka-Fort Jones area

Borns, 1980, Progressive deformation, blueschist terrane, Yreka-Fort Jones area

Borns, 1981, Blueschist metamorphism, Yreka-Ft. Jones area

Borns, 1984, Ecologites in Stuart Fork terrane

Coleman and Lanphere, 1971, Blueschists, eclogites, and amphibolites

Cotkin and Cotkin, 1985, Early Paleozoic blueschist, eastern Klamath Mountains

Cotkin, 1986, Blueschist from the schist of Skookum gulch

Cotkin, 1987, Early Paleozoic blueschist, Skookum Gulch

Cotkin and others, 1992, Early Paleozoic blueschist, schist of Skookum Gulch

Dunn and others, 1993, Tectonic blocks at Horse Mountain

Goodge, 1985, Blueschist assemblages in Stuart Fork terrane

Goodge, 1992, Cogenetic Permo-Triassic melange and blueschist terranes

Hotz, 1973, Blueschist in Yreka-Fort Jones area

Hotz, 1973, Blueschist in Yreka-Port Jones area

Hotz, 1977, Blueschist in Yreka-Fort Jones area

Hotz and others, 1977, Triassic blueschist, northern California and north-central Oregon

Isozaki and Maruyama, 1992, Subhorizontal sandwich structure of cordilleran blueschist

\section{Condrey Mountain}

Donato and Coleman, 1979, Deformation and metamorphism, schist of Condrey Mountain

Donato and others, 1980, Geology of Condrey Mountain Schist

Grover, 1984, Progressive metamorphism west of Condrey Mountain dome

Grover and Rice, 1985, Progressive metamorphic sequence west of Condrey Mountain dome

Helper, 1983, Blueschist-greenschist facies terrane, Condrey Mtn Schist

Helper, 1985, Constraints on origin of Condrey Mountain Schist

Helper, 1986, Deformation and high P/T metamorphism, Condrey Mountain window

Helper, 1986, Early Cretaceous high P/T schists: An outlier of Franciscan?

Helper and others, 1989, Early Cretaceous metamorphic ages and Middle Jurassic U-Pb zircon protolith ages

Helper, 1992, Late Jurassic-Early Cretaceous underplating during high P/T metamorphism

Matzner, 1986, Metamorphism of early Paleozoic island arc and Mesozoic plutonic rocks intruding Trinity peridotite

Other

Barrow and Metcalf, 2002, Central metamorphic terrane: evidence of a mid-ocean ridge origin:

Barrows, 1969, Inverted, gradational sequence of basic metamorphic rocks along Scott River

Blake and Wentworth, 1992, Metamorphic facies map of western California and southwestern Oregon

Cashman, 1980, Devonian metamorphic event, northeastern Klamath Mountains

Coleman, 1972, Colebrooke Schist, relation to tectonic evolution

Coleman, 1973, Metamorphism and plate tectonics, southwest Oregon

Coleman and Lanphere, 1991, Briggs Creek amphibolite

Coleman and Peterman, 1969, Colebrooke schist

Coleman and otheres, 1977, Amphibolite of Briggs Creek, a slice of metamorphosed oceanic crust

Coleman and others, 1986, Metamorphic framework of central Klamath Mtns. and adjacent Coast 


\section{Ranges}

Coleman and others, 1988, Tectonic and regional metamorphic framework of Klamath Mountains and adjacent Coast Ranges

Davis, 1962, Metamorphic rocks, southwestern quarter of Coffee Creek quadrangle

Davis, 1966, Metamorphic and granitic history, Klamath Mountains

Davis and Lipman, 1962, Revised structural sequence of pre-Cretaceous metamorphic rocks, southern Klamath Mountains

Donato, 1986, Polyphase metamorphic history, Marble Mountain terrane

Donato, 1987, May Creek Schist, remnant of an incipient back arc basin?

Donato, 1989, Metamorphism of ophiolitic tectonic melange

Ernst, 1992, Metamorphism of the western Cordillera and its relationship to tectonics

Ferns and Kays, 1978, Contrasting metamorphic terranes, Siskiyou Mountains

Goodge, 1987, Polyphase metamorphism, Early Mesozoic oceanic rocks

Goodge, 1987, Polyphase metamorphic evolution, Stuart Fork terrane

Goodge, 1989, Polyphase metamorphism, Stuart Fork terrane

Goodge, 1995, Pre-Middle Jurassic accretionary metamorphism in southern Klamath Mountains

Grover and Rice, 1985, Progressive metamorphic sequence west of Condrey Mountain dome

Hacker, 1989, Metamorphism of high-MgO volcanic rocks, Hayfork/North Fork terranes

Hacker and Ernst, 1990, Metamorphism and metasomatism of high-MgO greenstones

Hacker and Ernst, 1992, Metamorphic map of Klamath Mountains

Hacker and others, 1992, Magnesian volcanic rocks, Klamath Mountains

Hacker and Goodge, 1990, Mesozoic high-pressure rocks, Klamath Mountains and Sierra Nevada

Haessig, 1989, Schist of Skookum Gulch, Callahan-Yreka area

Harper and others, 1990, Metamorphic sole beneath Josephine ophiolite

Hershey, 1901, Metamorphic formations, northwestern California

Holdaway, 1963, Mafic metamorphic rocks in a portion of Klamath Mountains

Holdaway, 1965, Basic regional metamorphic rocks in part of Klamath Mountains

Hotz, 1979, Regional metamorphism, Condrey Mountain quadrangle

Kays, 1987, Metamorphism of TRPZ oceanic rocks, Blue and Klamath Mountains

Kays, 1992, Model for metamorphism, northern Klamath Mountains

Kays and Rice, 1991, Prograde Nevadan metamorphism

Kays and others, 1988, Metamorphism of Triassic-Paleozoic belt rocks

Kays and Helming, 1966, Anomalous metamorphism of Jurassic rocks

Kays and others, 1972, Character and genesis of gneissic amphibolites

Kays, 1970, Mesozoic metamorphism, May Creek Schist belt

Kays, 1973, Metamorphism-plutonism in western Paleozoic and Triassic belt

Kays, 1995, Metamorphism in the northern Klamath Mountains, Oregon

Lieberman, J. L., 1983, Marble and peridotite, Seiad Valley Complex

Lieberman and Rice, 1986, Marble and peridotite, Seiad ultramafic complex

Lipman, 1962, Isoclinal folding and metamorphism in Trinity Alps

Olson, 1977, Ordovician-Silurian metamorphism, Early Devonian intrusives

Peacock, 1985, Inverted metamorphic gradient and fluid evolution, central metamorphic belt

Peacock, 1985, Thermal and fluid evolution of Trinity thrust system, effects of fluids in subduction zones

Peacock, 1987, Subduction related inverted metamorphic gradients

Peacock,1988, Inverted metamorphic gradients in the westernmost Cordillera

Peacock and Norris, 1988, Metamorphic evolution of Central Metamorphic belt, inverted metamorphic gradient beneath Trinity Peridotite

Pratt, 1964, Jurassic(?) regional metamorphism, Marble Mountains

Rawson and Petersen, 1982, Equivalence of Rattlesnake Creek terrane and high-grade rocks of western Paleozioc and Triassic belt

Rawson, 1984, Regional metamorphism of rodingites and related rocks, north-central Klamath Mountains

Snoke and Barnes, 2002, Anatexis and dynamothermal metamorphism during emplacement of a syntectonic oceanic arc-root pluton, Klamath Mountains

Welsh, 1978, Emplacement of ultramafic rocks and metamorphism, Marble Mountains

Welsh, 1979, Antigorite-chlorite relationships, Marble Mountains

Wood, 1971, Late Mesozoic schists, NW California and SW Oregon 


\section{MAGMATISM}

Barnes and others, 1996, Middle Jurassic to Cretaceous magmatism in Klamath and Blue Mountains Barnes and others, 1996, Source and tectonic implications of tonalite-trondhjemite magmatism

Barnes and others, 1999, Shoshonitic magmatism during contracturaal deformation

Barnes and others, 2002, Jurassic arc magmatism in the Klamath Mountains

Lipman, 1992, Magmatism in the Cordilleran United States; Progress and problems

Wallin and others, 1991, Early Paleozoic magmatism, eastern Klamath Mountains

\section{PLUTONS}

Ashland

Donato, 1975, Geology and petrology of a portion of Ashland pluton

Gribble and Barnes, 1987, Composite Ashland pluton: Multiple felsic magmas in a tilted pluton

Gribble and others, 1990, Geochemistry and intrusive history, Ashland pluton

Barnes and others, 1989, Geochemistry of Caribou pluton

Barnes and others, 1992, Petrology of Caribou Mountain pluton

Davis, 1962, Emplacement of a foliated, domical pluton

Davis, 1963, Emplacement of Caribou Mountain pluton

Strauss, 1983, Variations in plagioclase zoning, Caribou Mountain pluton

Vennum, 1971, Petrology of Castle Crags pluton

\section{Castle Crags}

Vennum, 1976, Petrology of Castle Crags pluton

Vennum, 1980, Petrology of Castle Crags Pluton

Vennum, 1994, Geology of Castle Crags

\section{Gibson Peak}

Lipman, 1963, Gibson Peak pluton, a discordant composite intrusion

Lipman, 1964, Mineralogy and paragenesis of amphiboles, Gibson Peak pluton

\section{Greyback}

Barnes and Johnson, 1992, Greyback pluton, Late Jurassic backarc(?) magmatism

Barnes and others, 1989, Geochemistry of Greyback pluton

Barnes and others, 1992, Greyback Pluton, magmatism in a back-arc environment

Barnes and others, 1995, Greyback pluton, magmatism in a back-arc environment

Godchaux, 1969, Petrology of Greyback Igneous Complex and contact aureole

Godchaux and Kays, 1969, Petrology of Greyback intrusive complex and contact aureole

Johnson and Barnes, 1991, Magma in late-stage felsic dikes, Greyback pluton

Emerson, 1969, Albitization of Pit River stock

\section{Pit River}

Fraticelli and others, 1985, Permian Pit River stock, McCloud plutonic belt,

Russian Peak

Cotkin, 1987, Petrology and geochemistry of Russian Peak pluton

Cotkin and Medaris, 1987, Petrogenesis of Russian Peak pluton

Cotkin and Medaris, 1991, Evolution of a mid-Jurassic calcalkaline intrusive complex: The Russian Peak pluton

Cotkin and Medaris, 1993, Crystallization conditions for calcalkaline Russian Peak intrusive complex

Cotkin and others, 1985, Rb-Sr systematics of Russian Peak pluton

Cotkin and others, 1991, Effects of differing fluid contents in two units of Russian Peak pluton

Mooring, 1978, Petrogenesis of Russian Peak ultramafic complex

Romey, 1962, Russian Peak batholith

\section{Wooley Creek}


Allen and others, 1982, Comagmatic nature of Wooley Creek Batholith and Slinkard Pluton

Barnes, 1982, Geology and petrology of Wooley Creek batholith

Barnes, 1983, Petrology and upward zonation of the Wooley Creek batholith

Barnes, 1987, Mineralogy of the Wooley Creek batholith, Slinkard pluton, and related dikes

Barnes and Allen, 1984, Fractionation in Wooley Creek batholith and Slinkard pluton magmatic system

English Peak

Schmidt, 1994, English Peak pluton, A complex composite pluton

Schmidt, 1994, Petrology and geochemistry, English Peak intrusive suite

Schmidt and Barnes, 1990, Enclaves and enclave swarms

Schmidt and Barnes, 1991, Chemical and petrologic characteristics

Seyfert, 1965, Compositional variation

Other plutons

Albers and others, 1981, Mule Mountain Stock--early Middle Devonian

Allen, 1981, Intrusive relations and petrography, Slinkard pluton

Barnes and others, 2002, Petrology of the Bear Mountsain intrusive complex

Boardman, 1985, Petrology of Salmon Mountain stock

Bero, 1980, Petrology of Heather Lake Pluton

Charlton, 1977, Petrology of Ironside Mountain batholith

Dorais, 1983, Geology and petrology of Shelly Lake pluton

Evernden and Kistler 1970, Chronology of emplacement of Mesozoic batholithic complexes

Gray and Page, 1985, Map of Lower Coon Mountain pluton

Griesau, 1992, Kinematic study of Summit Valley plutonic complex

Lipman, 1964, Structure and petrology of Canyon Creek pluton

Petersen, 1993, Geology and geochemistry of Craggy Peak pluton, Deadman Peak pluton, and Billy's Peak mafic complex

Petersen and Barnes, 1986, Magma mingling and compositional variation, Craggy Creek pluton

Powers, 1926, History and petrography, Siskiyou batholith

Seager, 1939, Petrology of Balaklala chonolith

Snoke and others, 1981, Bear Mountain igneous complex

Staude and Moring, 1988, Walker Point mafic-ultramafic pluton

Wallin and others, 1995, Silurian plutonism in Trinity terrane (Neoproterozoic and Ordovician)

Wetencamp and others, 2003, Variation in rocks previously mapped as Pearse Peak diorite

Barnes, 1991, Tilted plutons--another look

\section{General features}

Barnes, 1991, Mid Jurassic and Early Cretaceous plutonism

Barnes and Rice, 1983, Tilted plutons

Barnes and others, 1987, Isotopic heterogeneity in tilted plutonic system

Barnes and others, 1986, Characteristics of tilted plutonic system

Barnes and others, 1986, Tilted plutons in Klamath Mountains

Barnes and others, 1990, Magmatic components of tilted plutonic system

Barnes and others, 1992, Isotopic variation among Jurassic and Early Cretaceous plutons

Barnes and others, 1992, Isotopic variation of pre- and post-Nevadan plutons

Barnes and others, 1994, Origin of tonalite and trondhjemite by crustal melting

Griesau and Harper, 1992, Plutonic complex intruding Orleans thrust

Heiken, 1976, Depressions, reflection of underlying batholiths?

Hershey, 1900, Granites of Sierra Costa Mountains

Hershey, 1901, Age of certain granites

Hinds, 1929, Intrusive rocks

Hinds, 1934, Age of last granitoid intrusives

Hotz, 1971, Plutonic rocks

Irwin, 1984, Plutonic belts in allochthonous terranes

Irwin, 1984, Preaccretion and postaccretion plutonic belts

Irwin, 1985, Plutonic belts in accreted terranes 
Lund and Baldwin, 1969, Diorite intrusions between Sixes and Pistol Rivers

Masi and others, 1981, Stable isotope systematics in Mesozoic granites

Page and others, 1983, Map showing characteristics of granitic plutons

Petersen and others, 1988, Geochemical comparison of pre- and post-Nevadan plutons

Potter and Grunder, 1989, Tectonic settings of Early

Cambrian and Ordovician intrusive rocks

Snoke and Bowman, 1977, Clinopyroxene-rich ultramafic and associated rocks

Snoke and others, 1982, Peridotitic to dioritic intrusive complexes

Thompson, 1988, Syn-metamorphic intrusions, Observation Peak area

Wright and Sharp, 1982, Mafic-ultramafic intrusive complexes., Klamath-Sierran region

Yule and others, 1996, The 175-135 Ma plutons reinterpreted as a single oceanic arc batholithic system

\section{OPHIOLITES}

Josephine

Alexander, 1992, Oceanic faulting and hydrothermal alteration

Alexander and Harper, 1990, Subseafloor hydrothermal alteration, basal sheeted dike complex

Alexander and Harper, 1992, Ancient analogue for slow- to intermediate-spreading oceanic ridges

Alexander and others, 1993, Fault-controlled subseafloor hydrothermal alteration in sheeted dike complex

Brown, 1965, Soil profiles on ultramafic rocks

Coulton and others, 1995, Oceanic versus emplacement age serpentinization in Josephine ophiolite

Dick, 1974, Terrestrial nickel-iron

Dick, 1975, Partial melting

Dick, 1975, Refractory residue of the generation of andesite

Dick, 1976, Origin emplacement

Dick, 1977, Evidence of partial melting

Dick, 1977, Partial melting, effect and consequence

Evans, 1980, Structure

Evans, 1984, Structure

Evans, 1987, Deformation

Frishman, 1980, High- and low-temperature mineral assemblages

Giaramita and Harper, 2001, Western outlier of the Josephine ophiolite(?) on the Elk River

Giaramita and Harper, 2002, Relations of a probable outlier of Josephine ophiolite, Elk River area

Grady, 1990, Rocks associated with the basal (Madstone) thrust

Grady and others, 1989, N-NE obduction along an amphibolite sole

Harding, 1988, Tectonites, record of upper mantle plastic flow

Harding and Bird, 1983, Accreting plate margin structures

Harper, 1979, "Anomalous" ophiolite underlying Galice Formation

Harper, 1980, Structure, petrology, and overlying rocks

Harper, 1980, Remains of a marginal basin

Harper, 1981, Structural history and overlying flysch

Harper, 1982, Large-scale rotations at spreading centers

Harper, 1983, Depositional contact between Galice Formation and ophiolite

Harper, 1984, Tectonic setting

Harper, 1984, The Josephine ophiolite

Harper, 1988, Episodic magma chambers and amagmatic extension

Harper, 1982, Geochemistry of dikes and lavas

Harper, 1982, Primary volatile contents in lavas in back-arc basin

Harper, 1985, Tectonic setting

Harper, 1985, Spreading ridges and depth to brittle/ductile transition

Harper, 1995, Pumpellyosite and prehnitite--Ca metasomatism

Harper, 1999, Tectonic implications of multiple magma types and Fe-Ti basalts

Harper, 2002, A Lau Basin model for the formation of Josephine ophiolite and related rift facies

Harper, 2003, Fe-Ti basalts and propagating-rift tectonics

Harper and Alexander, 1993, Two styles of mineralization

Harper and Alexander, 1991, Growth faulting and tilting

Harper and Coulton, 1993, Where is the paleo-Moho in Ophiolites 
Harper and others, 1994, Formation, emplacement, and the Nevadan orogeny

Harper and others, 1985, Tectonic setting of sea-floor spreading

Harper and others, 1989, Generation, translation, and emplacement

Harper and Alexander, 1990, Hydrothermal metamorphism at slow-spreading ridge

Harper and others, 1988, Study of subseafloor metamorphism

Harper and others, 1985, Setting of sea-floor spreading

Jorgenson, 1970, Illinois River gabbro, part of Josephine Peridotite-Gabbro

Jorgenson, 1971, Zoning in plagioclase from gabbroic rocks

Jorgenson, 1979, Textural banding in igneous rocks

Kimball, 1988, Hydrothermal alteration of ultramafic cumulates

Loney and Himmelberg, 1976, Vulcan Peak alpine-type peridotite

Loney and Himmelberg, 1977, Gabbroic complex along border of Josephine Peridotite, Vulcan Peak area

Milby, 1990, Fluid inclusions, oceanic crustal rocks

Norrell 1989, Implications for structural processes at slow spreading centers

Norrell and others, 1987, Oceanic faults and serpentinitie mylonites in the Josephine ophiolite

Norrell and others, 1989, Microstructure of serpentinite mylonites

Norrell and others, 1989, Planar fabrics

Norrell and Harper, 1988, Faulting and extension at mid-ocean ridges

Norrell and Harper, 1990, Ultramafic fault rocks and oceanic detachment

Pinto-Auso, 1984, Pelagic/hemipelagic sequence overlying ophiolite

Ramer, 1967, Petrology of a portion of Josephine Peridotite

Vail, 1976, Josephine Complex, an ophiolite

Vail, 1977, Geology and geochemistry, Oregon Mountain area

Vail and Dasch, 1977, Jurassic ophiolitic rocks

Wright and Wyld, 1986, Xenocrystic Precambrian zircon, Devils Elbow remnant

Wyld and Wright, 1986, Xenocrystic Precambrian zircon, continuation of Josephine ophiolite

Wyld and Wright, 1988, Devils Elbow ophiolite remnant and overlying Galice

Yule and Saleeby, 1991, Older oceanic crust and protracted fracture zone assemblage beneath Josephine ophiolite

Ando, 1977, Disrupted ophiolitic sequence

North Fork

Ando, 1979, Anomalous disrupted ophiolite

Ando and Saleeby, 1980, Implications of a Permo-Triassic age

Preston Peak

Snoke, 1971, Thrust plate of ophiolitic rocks, Preston Peak area

Snoke, 1973, Spinifex ultramafic rocks, Preston Peak ophiolite

Snoke, 1974, Ultramafic-mafic rock suites, Preston Peak area

Snoke, 1977, Thrust plate of ophiolitic rocks, Preston Peak area

Snoke and others, 1977, Preston Peak ophiolite, an immature island arc

Snoke and Calk, 1978, Jackstraw-textured talc-olivine rocks, Preston Peak area

Snoke and Whitney, 1979, Relict pyroxenes, Preston Peak ophiolite

\section{Tom Martin}

Barrows, 1969, Petrogenesis of an Alpine ultramafic complex

Barrows, 1969, Hamburg-McGuffy Creek area, and Tom Martin ultramafic complex

Hanks, 1981, Emplacement history of Tom Martin ultramafic complex

Hanks, 1981, Relationship to adjacent metamorphic rocks

Trinity ophiolite, complex, terrane

Aubin and Lee, 1996, Petrology and geochemistry of the Trinity ulramafic sheet near Kangaroo Lake Boudier and others, 1989, Structure of an atypical ophiolite

Boudier and others, 1983, The Trinity plagioclase lherzolite

Brouxel, 1988, Flow differentiation in a multiple injection dike

Brouxel and Lapierre, 1988, Geochemistry of island-arc-back-arc basin system

Bruckno, 1997, Geochemistry of the Trinity ophiolite and complex 
Cannat and Lecuyer, 1991, Epithermal magma chambers

Carter and Quick, 1987, Ultramafic rocks at Eunice Bluff

Goullaud, 1973, Gabbroic body in Trinity ultramafic pluton

Goullaud, 1975, Trinity mafic-ultramafic complex

Goullaud, 1977, Structural synthesis, Coffee Creek area

Goullaud, 1978, Petrology and structure of gabbroic body in the Trinity ultramfic pluton

Grau and others, 1991, New constraints from REE and Nd isotope data

Irwin and Lipman, 1962, Regional ultramafic sheet

Jacobsen and others, 1984, Nd and Sr isotopic study

Lécuyer, 1990, Hydrothermalisme fossile dans une paleocroûte océanique

Lécuyer, 1990, Chemical transfer between mantle xenoliths and basic magmas

Lécuyer and Brouxel, 1988, Diversity and petrogenesis of magmas

Lécuyer and others, 1990, Elemental fluxes during hydrothermal alteration

Lecuyer and others, 1991, Magmas at a fossil slow-spreading center

LeSueur and Boudier, 1986, Genese d'une ophiolite atypique

LeSueur and others, 1984, Study of an untypical ophiolite

Lindsley-Griffin, 1973, Lower Paleozoic ophiolite of Scott Mountains

Lindsley-Griffin, 1975, Northwestern edge of Trinity ophiolite

Lindsley-Griffin, 1976, Feldspathic lherzolites

Lindsley-Griffin, 1977, The Trinity Ophiolite

Lindsley-Griffin, 1977, Paleogeographic implications of ophiolites

Lindsley-Griffin, 1982, Structure, stratigraphy, petrology, and regional relationships

Lindsley-Griffin, 1991, Polygenetic ophiolitic assemblage

Lindsley-Griffin, 1992, Ophiolitic lower Paleozoic Trinity Complex

Lindsley-Griffin and Rohr, 1977, Bibliography of Trinity complex and eastern Klamath Mountains

Lipman, 1964, Origin of an ultramafic pluton

Masson, 1990, Sheeted dikes in Trinity ophiolite

Masson, 1991, Grey Rocks, remnant of submarine volcano

Metcalf and Wallin, 1996, Supra-subduction zone setting of Trinity terrane

Metcalf and others, 1998, Devonian volcanics: An island-arc or volcanic cover of the Trinity ophiolite?

Noller, 1984, Generation of chromite schlieren and compositional layers

Noller and Carter, 1985, Origins of dunite and chromite schlieren

Norris, 1983, Metamorphism at base of Trinity peridotite

Peacock, 1984, Serpentinization history

Peacock, 1987, Serpentinization and infiltration metasomatism

Peterson, 1987, The Billy's Peak mafic dike complex

Petersen and others, 1991, Billy's Peak mafic complex, roots of island arc

Quick, 1980, The structural and petrologic evolution of the Trinity peridotite

Quick, 1981, Petrology and petrogenesis

Quick, 1981, An upper mantle diapir

Quick, 1981, Large tabular dunite bodies

Quick, 1981, Igneous history, multiple depths of basalt genesis

Quick and Albee, 1979, Evidence for partial melting

Quick and Albee, 1979, Dike-wall rock interactions

Quick and others, 1980, Structural and petrologic evolution

Quick and others, 1982, Upper-mantle magma chamber

Smith and others, 1999, Geochemical comparison of Silurian and Devonian mafic intrusive complexes

Tozer and Lindsley-Griffin, 1993, Trinity Complex plagiogranites

Wallin and others, 1990, Cambro-Ordovician ophiolite or composite terrane?

Wallin and Metcalf, 1997, Superposed Silurian and Devonian mafic intrusive complexes

Wallin and Metcalf, 1998, Supra-subduction zone ophiolite formed in an extensional forearc

Willse and others, 1998, Emplacement of Lower Silurian Bonanza King mafic intrusive complex

Other ophiolites and general features

Bogdanov and Dobretsov, 1987, Ophiolites of California and Oregon

Cannat, 1983, Cinématique de charriages ophiolitiques

Castro, 1993, Eltapom ophiolite remnant, Rattlesnake Creek terrane 
Chambers, 1983, Ultramafic and associated rocks, Northeast Marble Mountains Wilderness

Chen and Shaw, 1982, Pb-Nd-Sr isotopic studies of California ophiolites

Coleman, 1967, Low-temperature reaction zones in alpine ultramafic rocks

Coleman, 1986, Ophiolites and accretion of North American cordillera

Coleman and Irwin, 1974, Ophiolites and ancient continental margins

Coleman and Irwin, eds., 1977, North American Ophiolites

Cullers and others, 1972, Rare-earth elements of some high temperature-pressure peridotites

Dick and Sinton, 1979, Compositional layering in alpine peridotites

Dollinger, 1969, Olivine from Seiad ultramafic complex

Donato, 1987, Evolution of an ophiolitic tectonic melange, Marble Mountains

Ferns, 1979, Wrangle Gap-Red Mountain ultramafic body

Foose, 1986, Magmatic sulfide occurrence in dismembered ophiolite

Gray, 1980, Lherzolitic and wehrlitic rock series at Tincup Peak

Gray, 1980, Igneous complex, Tincup Peak, Kalmiopsis Wilderness

Gray, 1981, Igneous complex at Tincup Peak, Kalmiopsis Wilderness

Godfrey, 1996, Ophiolitic basement of the Great Valley forarc basin,, from seismic and gravity data

Henry and Medaris, 1976, Pyroxene and olivine-spinel geothermometers

Himmelberg and Loney, 1973, Vulcan Peak Alpine-type peridotite

Irwin, 1977, Ophiolitic terranes of California, Oregon, and Nevada

Irwin, 1979, Ophiolitic terranes of part of western United States

Kays and others, 1977, Complementary meta-gabbros and peridotites

Lieberman and Rice, 1983, Prograde metamorphism of marble and peridotite, Seiad ultramafic complex

Lipman, 1964, Two contrasting groups of ultramafic intrusions

Loomis and Gottschalk, 1981, Hydrothermal origin of mafic layers, Seiad ultramafic complex

Lundquist, 1982, Deformation history, Seiad Complex

Medaris, 1966, Geology of Seiad Valley area, petrology of Seiad ultramafic complex

Medaris, 1966, High-temperature metamorphic rocks associated with an ultramafic complex

Medaris, 1969, Coexisting olivine, pyroxene, and spinel in Seiad ultramafic complex

Medaris, 1972, High-pressure peridotites, southwestern Oregon

Medaris, 1976, Application of pyroxene and olivine-spinel geothermometry

Medaris and Dott, 1970, Mantle-derived peridotites, southwestern Oregon

Medaris and Dott, 1973, "Ophiolites" and "flysch" in the Klamath--Coast Range Region

Medaris and others, 1980, Prograde metamorphism of serpentinites, western Paleozoic and Triassic belt

Migues, 1968, Rodingites in ultramafites

Newkirk, 1977, Petrology of Ono metaperidotite

Nishimori and others, 1972, Mafic and ultramafic layered rocks, ocean floor and orogenic belts

Rawson and Rice, 1983, Metarodingites from an ultramafic-mafic complex, Huckleberry Mountain

Rice and Ferns, 1980, Metarodingite in Wrangle Gap-Red Mountain Ultramafic complex

Saleeby, 1992, Settings of U.S. Cordilleran ophiolites

Saleeby and others, 1980, Ophiolite accretion

Saleeby and others, 1982, Time relations and structural-stratigraphic patterns in ophiolite accretion

Saleeby and others, 1979, Ophiolite terranes of California

Terres, 1979, Structure and petrology, Forest Mountain ultramafic body

Throckmorton, 1978, Petrology of Castle Lake peridotite-gabbro mass

Wagner and Ramp, 1958, Occurrences of peridotite-serpentine in Oregon

STRATIGRAPHY

Albers and Robertson, 1952, Permian age for Dekkas andesite

Albers and Robertson, 1961, East Shasta copper-zinc district

Bestland and others, 1987, Amphibolite facies thrust-slice, Marble Mountains terrane

Boucot, 1970, Pre-Carboniferous history, eastern Klamath Mountains

Cashman, 1978, Volcaniclastic sequence, central Klamath Mountains

Churkin, 1958, Silurian stratigraphy, Yreka and China Mountain quadrangles

Churkin, 1960, Silurian strata

Churkin and Langenheim, 1960, Silurian strata

Coogan, 1957, Stratigraphy and correlation, Permian Nosoni and Dekkas

Coogan, 1960, Stratigraphy and paleontology, Nosoni and Dekkas 
Cox and Pratt, 1973, Submarine chert-argillite slide-breccia

Cram-Barry and Wallin, 1990, Stratigraphy and sedimentology, Gazelle Formation

Curtis, 1983, Stratigraphy and origin of Pit Formation

Curtis, 1980, Stratigraphy and structure, Bonanza King and Schell Mountain quadrangles

Demirman, 1960, Sedimentation and diagenesis, McCloud Limestone

Demirman and Harbaugh, 1965, Petrography and origin, McCloud limestone

Diller, 1903, Klamath Mountain section

Diller, 1905, Bragdon formation

Diller, 1907, Mesozoic sediments, southwestern Oregon

Diller and Schuchert, 1894, Discovery of Devonian rocks

Du and others, 1992, Reinterpretation of Hosselkus Limestone

Eastoe and Gustin, 1986, Pit Formation, debris flow and exhalite

Eastoe and others, 1987, Recognition of olistostromes, Pit Formation

Elliott, 1974, Late Cretaceous sublittoral and fluvial sedimentation

Engelhardt, 1966, Paleozoic-Triassic contact, Jackson County

Evans, 1966, McCloud Limestone, South Gray Rocks area

Fagin, 1980, Structural and depositional patterns, Redding section

Fairbanks, 1894, Mesozoic and Paleozoic, Shasta County

Garcia, 1976, Rogue River area, identification of ancient volcanic arcs

Garcia, 1976, Rogue River island arc complex

Garcia, 1979, Petrology, Rogue and Galice formations, identification of island arc sequence

Gin and Wallin, 1994, New interpretation, Moffett Creek Formation

Harbaugh, 1955, Stratigraphy and paleontology, portions of Klamath Mountains

Heinrich, 1966, Applegate Group, Kinney Mountain area

Hershey, 1904, Bragdon formation

Hershey, 1906, Western Klamath stratigraphy

Heyl and Walker, 1949, Limestone near Gazelle

Hinds, 1931, Most ancient formations, Klamath Mountains

Hinds, 1932, Paleozoic eruptive rocks

Hinds, 1933, Formations of Redding-Weaverville districts

Hinds, 1935, Mesozoic and Cenozoic eruptive rocks

Hinds, 1940, Paleozoic section, southern Klamath Mountains

Hotz, 1940, Paleozoic volcanic rocks, Medford quadrangle

Hotz, 1969, Relations between Dothan and Rogue Formations

Hotz, 1977, Paleozoic rocks, Yreka area

Irwin, 1960, Abrams and Salmon schists, Weaverville quadrangle

Irwin, 1977, Review of Paleozoic rocks

Johnson, 1977, Mesozoic metavolcanic sequences, northern Klamath Mountains

Klanderman, 1978, Antelope Mountain Quartzite, Yreka

Lindsley-Griffin, 1983, Lower Paleozoic, eastern Klamath Mountains

Lindsley-Griffin and Fisher, 1989, Contact between melange and shales of Gazelle Formation

Lindsley-Griffin and Griffin, 1983, Trinity terrane, a Paleozoic microplate assemblage

Lindsley-Griffin and others, 1989, Unidentified fossil-like objects, Antelope Mountain Quartzite

Lindsley-Griffin and others, 1991, Redefinition of Gazelle Formation

Lukens, 1985, Limestones, Western Paleozoic and Triassic belt

Madrid and others, 1992, Devonian and older rocks in accreted terranes

McCormick, 1986, Facies and environmenta, Hosselkus Limestone

Merriam, 1961, Silurian and Devonian rocks, Klamath Mountains

Miller and Hacker, 1993, Structure and stratigraphy, Marble Mountain terrane

Miller, 1983, Upper Paleozoic, eastern Klamath belt

Miller, 1987, Stratigraphic record of island arc, eastern Klamath Mountains

Miller, 1988, Permo-Triassic deformation, Eastern Klamath terrane

Miller, 1989, Late Paleozoic evolution of eastern Klamath terrane

Miller and Cui, 1989, Submarine fan and sediment provences, Bragdon Formation

Mortimer, 1983, Stratigraphy and volcanic geochemistry of marginal basin assemblage near Yreka

Murray and Condie, 1971, Paleozoic and pre-Cretaceous Mesozoic history, eastern Klamath province

Murray and Condie, 1973, Post-Ordovician to Early Mesozoic history, eastern Klamath subprovince 
Noto, 1999, Structure and stratigraphy of the Antelope Mountain Quartzite

Poole and others, 1977, Silurian and Devonian paleogeography of the western United States

Poole and others, 1992, Latest Precambrian to latest Devonian time: Development of a continental margin

Potter, 1977, Moffett Creek and Gazelle Formations northeast of Gregg Ranch

Potter, 1982, Klamath Mountains, Ordovician system

Potter and Boucot, 1971, Ashgillian, Late Ordovician brachiopods from eastern Klamath Mountains

Potter and others, 1977, Relations and paleogeographic models, Lower Paleozoic

Potter and others, 1990, Early Paleozoic relations, eastern Klamath belt

Roehl, 1955, Paleozoic geosyncline

Rohr, 1978, Stratigraphy, structure, and early Paleozoic Gastropoda, Callahan area

Rohr and Boucot, 1971, Pre-Late Silurian igneous complex

Rohr and Potter, 1973, Paleozoic of Callahan-Gazelle area

Rohr and others, 1974, Age corrections for some Silurian localities

Ross, 1991, Pennsylvanian paleogeography, western United States

Sheehan and Boucot, 1991, Silurian paleogeography, western United States

Smith, 1894, Metamorphic series of Shasta County

Smith, 1910, Geologic record of California

Smith, 1894, Trias and Jura of Shasta County

Smith, 1894, Carboniferous strata of Shasta County

Smith, 1895, Notes on metamorphic series, Shasta region

Stauffer, 1930, Devonian of California

Taliaferro, 1942, Jurassic, southwestern Oregon and California

Tomlinson, 1993, Tectonostratigraphy, Bolan Lake area

Trabert and Wallin, 1992, Gazelle Formation, deposition in trench-slope setting

Wallin, 1988, Lower Paleozoic terrigenous clastic sedimentation, Yreka-Callahan area

Wallin and Trabert, 1992, Devonian trench-slope basin

Wallin and Trabert, 1994, Eruption-controlled epiclastic sedimentation, Devonian trench-slope basin

Watkins, 1972, Carboniferous System between Hirz Mountain and Kabyai Creek

Watkins, 1979, Carboniferous rocks, eastern Klamath Mountains

Watkins, 1985, Volcaniclastic and carbonate sedimentation, Baird Formation and McCloud Limestone

Watkins, 1985, Volcaniclastic and carbonate sedimentation, late Paleozoic island-arc deposits

Watkins, 1986, Turbidite facies and basinal development, eastern Klamath Mountains

Watkins, 1986, Reply on Volcaniclastic and carbonate sedimentation

Watkins, 1990, Carbonate bank sedimentation, Carboniferous island arc deposits

Watkins, 1993, Carbonate bank sedimentation in a volcaniclastic arc setting

Watkins and Bergk-Hall, 1991, Progradational development, Lower Permian carbonate platform

Watkins and Flory, 1986, Island arc sedimentation, Kennett Formation

Wells and Hotz, 1941, Mesozoic volcanic series, southwest Oregon

Wells and others, 1951, Pre-Cretaceous stratigraphy, northern Klamath Mountains

Wells and others, 1959, Upper Ordovician(?) and Upper Silurian, the northern Klamath Mountains

Westman, 1947, Silurian of Klamath Mountains Province

Wheeler, 1939, Age of Dekkas volcanic rocks

Wheeler, 1940, Permian volcanism, western North America

Widmier, 1963, Mesozoic stratigraphy, eugeosynclinal sedimentation

Wise, 1969, Galice Formation, Babyfoot Lake area

Yancey and Hanger, 1986, Comment on "Volcaniclastic and carbonate sedimentation..."

\section{OVERLAP STRATA}

Cretaceous

Anderson, 1895, Cretaceous beds, Rogue River Valley

Anderson, 1901, Neocene basins

Anderson, 1902 Cretaceous deposits, Pacific Coast

Anderson, 1931, Upper Cretaceous (Chico), Siskiyou County

Anderson, 1938, Lower Cretaceous, California and Oregon

Anderson, 1958, Upper Cretaceous, Pacific Coast

Boggs and Swanson, 1970, Unusual slump structure, Cretaceous(?) sandstones 
Diller, 1893, Cretaceous and early Tertiary, northern California and Oregon

Diller, 1907, Pre-volcanic auriferous gravels

Diller and Stanton, 1894, Shasta-Chico series

Dott, 1966, Late Jurassic unconformity, southwestern Oregon

Elliott, 1971, Late Cretaceous rocks near Hilt and Hornbrook

Elliott, 1974, Late Cretaceous sublittoral and fluvial sedimentation

Erskine and others, 1984, Structural edge of the Cretaceous Hornbrook basin

Hershey, 1902, Neocene deposits

Hershey, 1902, Cretaceous outliers

Imlay and others, 1959, Certain Jurassic and Lower Cretaceous formations, southwestern Oregon

Jameossanaie and Lindsley-Griffin, 1993, Palynology and plate tectonics, Cretaceous terrestrial sediments

Jones, 1959, Upper Cretaceous, Yreka-Hornbrook area

Jones, 1960, Lower Cretaceous (Albian) fossils, southwestern Oregon

Jones, 1972, Structural significance, Upper Mesozoic biostratigraphic units

Jones and Imlay, 1973, Upper Jurassic and Lower Cretaceous rocks, Riddle area

Jones and Irwin, 1971, Displacement of Early Cretaceous shoreline

Lindsley-Griffin and others, 1993, Post-accretion, Cretaceous overlap sequence

McKnight, 1964, Cretaceous near Mitchell

McKnight, 1971, Cretaceous and Eocene rocks, Medford-Ashland region

Miller and others, 1992, Late Cretaceous to early Eocene geologic evolution, U.S. Cordillera

Nilsen, 1984, Upper Cretaceous Hornbrook Formation, Oregon and California

Nilsen, 1993, Stratigraphy of Cretaceous Hornbrook Formation

Nilsen and others, 1983, Geologic map of the outcrop area of the Hornbrook Formation

Peck and others, 1956, Upper Cretaceous rocks, Oregon and California

Popenoe, 1937, Upper Cretaceous stratigraphy and fauna, Redding quadrangle

Popenoe, 1938, Cretaceous stratigraphy and faunas, Redding quadrangle

Short and Ingersoll, 1990, Petrofacies and provenance of the Great Valley

Sliter and others, 1984, Cretaceous Hornbrook Formation

Wetzstein, 1986, Cretaceous conglomerate, eastern Klamath Mountains

Wetzstein and others, 1986, Cretaceous paleogeography, eastern Klamath Mountains

Aalto, 1988, Montgomery Creek Formation

\section{Tertiary}

Aalto and others, 1991, Sediment provenance and Cenozoic tectonic evolution

Aalto and others, 1995, Neogene paleogeography and tectonics

Carlton, 1972, Colestine Formation (Eocene)

Dickinson and otheers, 1979, Paleogene sediment dispersal and paleotectonics

Higinbotham, 1987, Montgomery Creek Formation

Knowlton, 1911, Flora of auriferous gravels

Lydon, 1964, Cenozoic volcanic flows

Lydon, 1964, "Silicate slag", Trinity County

Lydon, 1964, Unusual phosphatic rock near Hyampom

Phillips, 1989, Weaverville Formation, vicinity of Weaverville

Phillips and Aalto, 1989, Weaverville Formation, tectonically controlled basin development

\section{PALEONTOLOGY}

\section{Conodonts}

Bergstrom and others, 1980, Significance of Ordovician conodonts

Irwin and others, 1983, Conodonts, western Paleozoic and Triassic belt

Savage, 1973, Devonian conodonts

Savage, 1974, Devonian conodont biostratigraphy

Savage, 1974, Conodont evidence of Late Eifelian age for Kennett Formation

Savage, 1975, Devonian conodont biostratigraphy

Savage, 1976, Lower Devonian (Gedinnian) conodonts, Grouse Creek area

Savage, 1976, Middle Devonian species of Polygnathus, Kennett Formation

Savage, 1977, Lower Devonian conodonts, Gazelle Formation 
Wardlaw and Jones, 1980, Triassic conodonts from eugeoclinal rocks, western North America

Corals

Belasky, 1994, Permian longitude of Stikinia, Wrangellia, and Eastern Klamath terranes based on coral biogeography

Belasky and Runnegar, 1994, Permian longitudes of Wrangellia, Stikinia, and Eastern Klamath terranes based on coral biogeography

Elias and Potter, 1984, Late Ordovician solitary rugose corals

Elias and Potter, 1984, Significance of Late Ordovician solitary rugose corals

Flory and Watkins, 1983, Lower Paleozoic tabulate corals

Langeheim and McCutcheon, 1959, Bayhaium merriamorum, a new Permian tabulate coral

Merriam, 1972, Silurian rugose corals

Miller and Wright, 1985, Implications of a Permian Tethyan coral

Miller and Wright, 1987, Paleogeographic implications of Permian Tethyan corals

Oliver, 1964, New occurrences of rugose coral Rhizophyllum

Oliver, 1975, Age of Corals from northern California

Stanley, 1979, Triassic coral buildups, western North America

Stevens, 1985, Permian colonial rugose corals and fusulinids, western North American tectonostratigraphic terranes

Stevens, 1989, Early Permian coral faunas in eastern Klamath Mountains, Stikine terrane, and cratonal Nevada and California

Stevens and Rycerski, 1983, Permian colonial rugose corals, aids in positioning of suspect terranes

Stevens, 1988, Eastern Klamath Mountains Permian coral province

Stevens and others, 1987, New Permian Waagenophyllid coral from Klamath Mountains

Wilson, 1967, Corals and other fossils from McCloud limestone

Wilson, 1982, Wolfcampian rugose and tabulate corals, Lower Permian McCloud Limestone

Wilson, 1984, Stony corals in Lower Permian McCloud Limestone

Wilson, 1985, Rugose corals from McCloud Limestone, Tombstone Mountain

\section{Fusulinids}

Bostwick and Nestell, 1966, Tethyan fusulinid fauna, central Oregon

Douglass, 1966, Permian Tethyan fusulinids from California

Elliott and Bostwick, 1973, Occurrence of Yabeina

Magginetti, 1984, "Klamath type" fusulinids in eastern California

Miller, 1985, Upper Paleozoic stratigraphy in terranes of McCloud fusulinid belt

Nestell and others, 1981, (Early Djulfian) Tethyan Foraminifera, southern Klamath Mountains

Nestell, 1991, The Upper Fusulinids Reichelina and Parareichelina: Evidence for long-distance transport

Ross, 1976, Fusulinacean provinces of North American Cordillera

Skinner and Wilde, 1965, Permian biostratigraphy and fusulinid faunas, Shasta Lake area

Skinner and Wilde, 1970, Pseudofusulina californica

Stevens and others, 1991, Upper Permian fusulinids Reichelina and Pararechelina, evidence for longdistance transport

Thompson and others, 1946, Permian fusulinids of California

Wheeler, 1933, Fusulinids of McCloud and Nosoni formations

Wilde, 1971, Phylogeny of Pseudofusulinella, and Early Permian stratigraphy

\section{Radiolarians}

Blair, 1978, Radiolarians from Mesozoic rocks in western Oregon

Blome and Irwin, 1983, Late Paleozoic to Jurassic radiolarians, North Fork terrane

Blome and Reed, 1995, Radiolarians of Quinn River Fm.: Correlations with Klamath terrane

Irwin and others, 1982, Radiolarian chert, North Fork terrane

Irwin and others, 1978, Radiolarians from pre-Nevadan rocks, Klamath Mountains

Irwin and others, 1977, Mesozoic radiolarians from pre-Nevadan rocks

Irwin and others, 1982, Map showing sampled radiolarian localities, western Paleozoic and Triassic belt

Murchey, 1985, Radiolarian assemblage variations, a tool for paleogeographic reconstructions 
Murchey and Jones, 1994, Two coeval Permian radiolarian-sponge associations, eastern Oregon

Murchey and others, 1983, Permian and lower Mesozoic radiolarian chert in western accreted terranes

Murchey and others, 1983, Radiolarian chert in western North America 109-125.

Noble and Renne, 1990, Significance of siliceous microfossils, Permo-Triassic Redding section

Pessagno and Blome, 1988, Data from Rogue and Galice Formations bearing on the age of the OxfordianKimmeridgian boundary and the Mirifusus first occurrence event

Pessagno and Blome, 1990, New stratigraphic, geochronometric, and paleolatitudinal data, western Klamath terrane

Pessagno and others, 1993, Jurassic Radiolaria from Josephine ophiolite and overlying strata

Pessagno and others, 1989, Xiphostylidae Haeckel and Parvivaccidae, from North American Jurassic

Roure and DeWever, 1983, Decouverte de radiolarites du Trias dans l'unite occidental des Klamath:

Consequences sur l'age des peridotites de Josephine

Smith, 1916, Notes on radiolarian cherts in Oregon

\section{Shelly fossils}

Boucot, 1971, Aenigmastrophia, new genus, a difficult Silurian brachiopod

Dutro, 1955, Brachiopod Isogramma in Baird Formation

Gordon, 1966, Upper Triassic bactritoid cephalopod

Hyatt and Smith, 1905, Triassic cephalopod genera of America

Miller and others, 1957, Permian ammonoids, western United States

Potter, 1987, Ordovician brachiopods, Horseshoe Gulch and Gregg Ranch

Potter, 1990, Ordovician brachiopod genus Bimuria, eastern Klamath Mountains

Potter, 1990, Middle and Late Ordovician brachiopods, eastern Klamath Mountains

Potter and others, 1980, Middle and Upper Ordovician brachiopods, Alaska and northern California

Rohr, 1980, Ordovician-Devonian Gastropods

Russell, 1929, Fossil pearls from Chico Formation

Savage and Boucot, 1978, Middle Devonian brachiopods, Kennett Formation

Silberling and Irwin, 1962, Triassic fossils, southern Klamath Mountains

Smith, 1914, Middle Triassic marine invertebrate faunas of North America

Smith, 1927, Upper Triassic marine invertebrate faunas of North America

Watkins, 1973, Carboniferous faunal associations, Shasta County

Watkins, 1974, Carboniferous Brachiopods, northern California

Watkins, 1975, Paleoecology of some Carboniferous Pectinacea

Wilson, 1967, Early Permian archaeogastropod Omphalotrochus whitneyi (Meek, 1864)

\section{Vertebrates}

Boucot and others, 1974, Middle Devonian orogeny, western North America?

Bryant, 1914, Teeth of a cestraciont shark from Upper Triassic

Bryant, 1914, Vertebrate fauna of the Triassic limestones at Cow Creek

Jordan, 1907, Fossil fishes of California

Merriam, 1902, Triassic Icthyopterygia, California and Nevada

Merriam, 1903, New Icthyosauria from Upper Triassic

Merriam, 1904, Marine reptile from Triassic

Merriam, 1905, Thalattosauria, marine reptiles from Triassic

Merriam, 1908, Triassic Icthyosauria

Merriam and Stock, 1925, Short-faced bear, Arctotherium, from Pleistocene

Sinclair and Furlong, 1904, Euceratherium, new ungulate from Quaternary caves

Wemple, 1906, Cestraciont teeth, west-American Triassic

Other and general

Barnett, 1982, Palynology and paleoecology, Weaverville Formation

Berry and others, 1973, Ordovician graptolites, eastern Klamath Mountains

Boucot and Potter, 1977, Middle Devonian orogeny and biogeographical relations

Boucot and others, 1973, Biogeographic relations of pre-Late Middle Devonian

Boucot and others, 1973, Pre-Late Middle Devonian biostratigraphy, eastern Klamath belt

Churkin, 1961, Silurian trilobites

Churkin, 1965, First occurrence of graptolites 
Diller, 1908, Strata containing Jurassic flora of Oregon

Du, 1994, Biogeography of two Late Triassic oceanic islands, Wallowa and Eastern Klamath terranes Irwin and Galanis, 1976, Map showing limestone and selected fossil localities

Jameossanaie and others, 1986, Palynology, age of Hornbrook basin

Lindsley-Griffin and others, 2002, Ediacaran Cyclomedusids from an accreted terrane

Lindsley-Griffin and others, 2003, Significance of Ediacaran cyclomedusids and other Pacific rim biota in Yreka terrane

MacGinitie, 1937, Flora of Weaverville beds

Meek, 1864, Description of carboniferous fossils

Miller, 1987, Terranes of Permian McCloud faunal affinity

Potter and others, 1989, Ordovician to Devonian biogeography, eastern Klamath terrane

Rigby and Potter, 1980, Ordovician Sphinctozoan sponges

Rigby and Potter, 1986, Ordovician Sphinctozoan sponges from the eastern Klamath Mountains

Rohr and others, 1975, Fossils from lower Paleozoic rocks

Stevens, 1977, Permian depositional provinces and tectonics

Stevens, 1985, Permian paleogeography based on distribution of Tethyan faunal elements

Stevens, 1991, Permian paleogeography

Stevens and others, 1990, Early Permian faunas, eastern Klamath terrane

Waines, 1960, Stromatoporoids of Kennett limestone

Watkins, 1990, Carboniferous and Permian island-arc deposits, eastern Klamath terrane

Watkins, 1994, Carboniferous to Lower Permian biostromal communities, eastern Klamath terrane

Watkins and Wilson, 1989, Biostromal organism Palaeoaplysina, McCloud Limestone

Watkins and others, 1989, Carboniferous and Permian biogeography, eastern Klamath terrane

Wheeler, 1935, New trilobite species

Wheeler, 1935, Fauna and correlation of McCloud Limestone

Wilson and Watkins, 1988, Biostrome-forming organism Palaeoaplysina, McCloud Limestone

Yancey and Hanger, 1985, Biotic replacement on a Permian island arc, McCloud Fm.

Yancey and Hanger, 1986, Endemisim of Early Permian invertebrates, eastern Klamath terrane

\section{TECTONICS AND REGIONAL CORRELATION}

Albers, 1964, Jurassic "oroclinal" folding and strike-slip faulting

Ando, Cashman, and Davis, 1976, Equivalence of Stuart Fork, North Fork, and Hayfork terranes

Aubouin and others, 1986, Traits généraux des cordillères de l'Ouest des Etats-Unis

Ave-Lallement and Oldow, 1988, Early Mesozoic southward migration of Cordilleran transpressional terranes

Barnes and others, 1993, Correlation of Applegate Group with terranes of the western Paleozoic and Triassic belt

Barnes and others, 1982, Basal detachment of western Paleozoic and Triassic belt

Belasky and others Hanger, 1999, Early Permian location of western North American terranes

Berry and Boucot, 1970, Correlation of North American Silurian rocks

Blackwelder, 1914, Orogenic epochs

Blake, 1984, Tectonstratigraphic terranes, southwestern Oregon

Blake and Jayko, 1986, Tectonic evolution, northwest California and southwest Oregon

Blake and others, 1982, Tectonostratigraphic terrane map, California

Blake and others, 1985, Tectonostratigraphic terranes of northern California

Blake and others, 1985, Tectonostratigraphic terranes, southwest Oregon

Blake and Jones, 1977, Tectonics of Yolla Bolly junction

Blake and Jones, 1977, Plate tectonic history, Yollo Bolly junction

Bond and DeVay, 1979, Petrology and provenance of pre-Upper Devonian quartzose flysch, northern Sierra Nevada

Brouxel and others, 1984, Marginal basin of Devonian age, Trinity ophiolite complex

Burchfiel and others, 1992, Tectonic overview of Cordilleran orogen

Burchfiel and Davis, 1972, Structural framework and evolution, cordilleran orogen

Burchfiel and Davis, 1975, Nature and controls of cordilleran orogenesis

Burchfiel and Davis, 1981, Triassic and Jurassic tectonic evolution, Klamath Mountains-Sierra Nevada

Busby-Spera and others, 1990, Triassic-Jurassic magmatic arc, Mojave-Sonoran Deserts and SierranKlamath region 
Calderwood, 1990, Constraints on onset and mechanism of Neogene uplift

Campos and others, 1992, Development and amalgamation of a "suspect terrane", eastern Klamath Mountains

Cannat, 1985, Tectonics of Seiad massif

Cannat and Boudier, 1985, Structural study of intra-oceanic thrusting, accretion geometry

Cannat and Boudier, 1985, Correction to "Structural study ....."

---1986, Reply

Cashman, 1977, Correlation of Duzel Formation with central metamorphic belt

Charvet and others, 1989, Effects of Antler orogeny in eastern Klamath Mountains

Charvet and others, 1987, Paleozoic polyphased tectonogenesis, eastern Klamath Mountains

Charvet and others, 1990, Tectono-magmatic evolution of Paleozoic and early Mesozoic

Churkin, 1974, Paleozoic marginal ocean basin-volcanic arc systems

Churkin and Eberlein, 1977, Ancient borderland terranes, North America Cordillera

Coleman and Helper, 1983, Significance of Condrey Mountain dome

Cotkin, 1989, Callahan event, Ordovician-Silurian tectonism

Cotkin, 1992, Ordovician-Silurian tectonism, the Callahan event

Cowan, 1980, Late Mesozoic tectonic events, Pacific Northwest

Cowan, 1993, Models for Late Jurassic and Early Cretaceous paleogeography of western Cordillera

Cowan and Bruhn, 1992, Late Jurassic to early Late Cretaceous geology of U.S. Cordillera

D'Allura and others, 1974, Cordilleran tectonic history

Davis, 1965, Correlation of Stuart Fork Fm. with western Paleozoic and Triassic belt

Davis, 1965, Mesozoic thrusting, south-central Klamaths

Davis, 1966, Age of thrusting and ultramafic intrusion

Davis, 1968, Tectonic correlations, Klamaths and Sierra Nevada

Davis, 1968, Westward thrust faulting

Davis, 1969, Tectonic correlations, Klamaths and Sierra Nevada

Davis and others,1978, Mesozoic construction of Cordilleran "collage"

Donato, 1984, Evolution of a tectonic melange

Donato, 1985, Evolution of ophiolitic tectonic melange, Marble Mountains

Donato, 1992, Ductile shear zone, implications for Nevadan accretion

Donato and Lanphere, 1992, Geochronologic studies of amphibolites

Dott, 1963, Classic Nevadan orogenesis, southwestern Oregon

Dott, 1965, Mesozoic-Cenozoic tectonic history

Dott, 1966, Cordilleran and Cascadan orogenies

Dott and Bourgeois, 1980, Late Mesozoic tectonics and sedimentation, Oregon coast

Elder and Cashman, 1990, Redefinition of early Mesozoic terranes

Ernst, 1991, Petrology and tectonic history, Sawyers Bar terrane

Ernst, ed., 1981, The geotectonic development of California

Ernst, 1983, Continental accretion and the metamorphic evolution of northern and central California

Eschelbacher and Wallin, 1998, Assembly of a subduction complex, Yreka subterrane

Fagin, 1983, Paleogeography and tectonics, Redding section

Fahan and Wright, 1984, Eastern Hayfork terrane, a subduction complex

Garvin, 1986, Digital topographic analysis of suspect terranes

Goodge, 1989, Early Mesozoic convergent margin deformation

Goodge, 1990, Coherent Late Triassic subduction complex, Stuart Fork terrane

Goodge and Hacker, 1989, Margin-parallel variation in subduction complexes

Goodge and Renne, 1993, Mid-Paleozoic olistoliths in eastern Hayfork terrane melange

Gray, 1985, Native terranes

Gray, 1986, Native terranes of central Klamath Mountains

Gray, 1985, Structural, geochronologic, and depositional history, western Klamath Mountains

Gray and Wright, 1984, Nature and tectonic setting, Rattlesnake Creek terrane

Hacker and Ernst, 1991, Evolution of Hayfork, Salmon River, North Fork, and Stuart Fork terranes

Hacker and Ernst, 1993, Jurassic orogeny, a geochronological analysis

Hacker and Peacock, 1990, Comparison of Central Metamorphic belt and Trinity terrane with Feather River terrane

Hacker and others, 1993, Genesis and evolution of a Permian-Jurassic magmatic arc/accretionary wedge, and reevaluation of terranes 
Hacker and others, 1995, Jurassic construction of Klamath Mountains Hamilton, 1969, Mesozoic California, underflow of Pacific mantle Hamilton, 1978, Mesozoic tectonics of western United States Harper, 1983, Nevadan orogeny, collapse of west-facing island arc/back-arc/remnant arc complex Harper and Wright, 1984, Jurassic tectonic evolution of Klamath Mountains

Harper and others, 1983, Lems Ridge olistostrome, sediment fill of ancient fracture zone Harper and others, 1983, Late Jurassic transform motion, western U. S.

Harper and Harding, 1986, Comment on "Structural study of intra-oceanic thrusting..."

Harper and Harding, 1986, Thrusting along margin of Condrey Mountain window

Harwood and Miller, eds., 1990, Paleozoic and early Mesozoic paleogeographic relations; Sierra

Nevada, Klamath Mountains, and related

Hietanen, 1981, Extension of Sierra Nevada-Klamath suture system

Hietanen, 1981, Feather River Area, part of the Sierra Nevada suture system

Hill, 1982, Tectonic boundaries between Happy Camp and Seiad Valley

Hill, 1983, Model for crystalline overthrusts and associated deformation

Hill, 1984, Metamorphic and deformational constraints on terrane assembly

Hill, 1984, Tectonic and metamorphic history, north-central Klamaths

Hill, 1985, Constraints on terrane assembly

Hinds, 1932, Diastrophic epochs, southern Klamath Mountains

Ingersoll and Schweickert, 1983, The Nevadan Orogeny, contrasts in Klamath Mountains and Sierra

Nevada

Ingersoll and Schweickert, 1986, Ophiolite genesis, Nevadan orogeny, and forearc initiation

Irwin, 1989, Cryptic tectonic domains of Klamath Mountains

Irwin, 1964, Late Mesozoic orogenies in ultramafic belts

Irwin, 1972, Terranes of western Paleozoic and Triassic belt

Irwin, 1973, Sequential minimum ages of oceanic crust in accreted tectonic plates

Irwin, 1981, Tectonic accretion of Klamath Mountains

Irwin, 1999, Relation of plutons to accretionary episodes of the Klamath Mountains

Irwin, 2002, Correlation of the Klamath Mountains and Sierra Nevada

Irwin, 2003, Correlation of the Klamath Mountains and Sierra Nevada

Irwin and Mankinen, 1998, Rotational and accretionary evolution of the Klamath Mountains

Irwin and Wooden, 1999, Plutons and accretionary episodes of the Klamath Mountains

Jachens and Griscom, 1983, Geometry of Gorda Plate beneath northern California

Jayko, 1990, Paleozoic arc-related rocks, eastern Klamath and northern Sierra terranes

Jones and Irwin, 197l, Structural implications of offset Early Cretaceous shoreline

Jones and others, 1972, Southeast Alaska, a displaced continental fragment?

Kays, 1968, Zones of alpine tectonism and metamorphism, southwestern Oregon

Kemp and Garcia, 1976, Klamath Mountains and Sierra Nevada Jurassic volcanic arc sequences

Ketner, 1959, Triassic paleotectonics of West Coast region

Ketner, 1967, Permian paleotectonics of West Coast region

Koch, 1963, Late Mesozoic orogenesis and sedimentation, southwest Oregon coast

Lapierre and others, 1990, Evolution of western North America Cordillera during Paleozoic and early Mesozoic

Lapierre and others, 1989, Plate tectonic models proposed for Cordilleran evolution during Paleozoic and Mesozoic

Lapierre and others, 1990, Plate tectonic models proposed for the Cordilleran evolution during Paleozoic and Early Mesozoic

Lindsley-Griffin, 1977, Early Paleozoic subduction complex in Klamath Mountains

Lindsley-Griffin, 1984, Deformational styles of melanges in accretionary complexes

MacGinitie, 1938, Relations along southwest border of Klamath Mountains

Martin, 1983, Un jalon dan l'evolution geodynamique de la bordure ouest americaine

Masson, 1993, Evidence for early Paleozoic orogeny, eastern Klamath terrane

Maxson, 1933, Structural relationships of coast and continental margin

Maxwell, 1974, Anatomy of an orogen

Maxwell, 1974, Early western margin of United States

McKee and others, 1956, Paleotectonic maps of Jurassic system

McNutt, 1983, Influence of plate subduction on isostatic compensation 
Metcalf and Barrow, 2002, Paleozoic-Mesozoic subduction related crustal growth

Miller, 1978, Early Mesozoic alkalic magma belt, western North America

Miller, 1994, Syn-magmatic extension in Early Jurassic(?) arc volcanoplutonic complex, central Klamath Mountains

Miller, 1986, Evolution of late Paleozoic island arc sequences

Miller, 1990, Episodic compressional tectonism in intra-arc setting, Eastern Klamath terrane

Miller and Harwood, 1989, Comparison of the Eastern Klamath and northern Sierra Buttes terranes

Miller and Harwood, 1990, Paleogeography of upper Paleozoic rocks, northern Sierra and eastern Klamath terranes

Miller and Harwood, 1989, Paleogeographic relations between the Klamath Mountains, northern Sierra Nevada, and western North America

Miller and Saleeby, 1989, Accretionary tectonics

Miller and Saleeby, 1991, Permian and Triassic paleogeography, eastern Klamath arc and eastern Hayfork subduction complex

Miller and others, 1992, Late Paleozoic paleogeographic and tectonic evolution, western U.S. Cordillera

Monger, 1973, Correlation of pre-Tertiary geology between Canadian and United States' Cordillera

Monger, 1975, Correlation of engeosynclinal tectono-stratigraphic belts, North American cordillera

Monger,1977, Upper Paleozoic rocks of western Cordillera and their bearing on Cordilleran evolution

Mortimer, 1984, Deformation, metamorphism and terrane amalgamation, NE Klamath Mountains

Mortimer, 1984, Permian to Jurassic rocks near Yreka

Mortimer, 1985, Constraints on the Permian to Jurassic evolution

Mortimer, 1985, Aspects of Middle Jurassic terrane juxtaposition

Murchey and Blake, 1993, Evidence for subduction of a major ocean plate along the California margin during the Middle to Early Jurassic

Noto and Wallin, 1998, Cretaceous inter-arc extension in Yreka terrane

Okulitch and others, 1989, Paleogeography of southeastern British Columbia; similarities to Klamath Mountains

Park-Jones, 1988, Tectonic setting and deformation of type Galice Formation

Pavlis, 1997, Jurassic history of Klamath Mountains province: A product of ridge subduction?

Peacock and Hacker, 1989, Correlation of Central Metamorphic belt with Feather River terrane

Potter and Hotz, 1977, Tectonic settings of early Paleozoic rocks south of Yreka

Potter and others, 1981, Ordovician-Silurian subduction and Silurian or older igneous units of possible magmatic arc origin

Potter and others, 1990, Biogeography of the Upper Ordovician Montgomery Limestone, and comparisons of Shoo Fly Complex with the Yreka terrane

Renne, 1991, Sediment provenance and Cenozoic tectonic evolution

Renne and others, 1986, Nature and timing of deformation, Redding section

Renne and Scott, 1988, Structural chronology, oroclinal deformation, and tectonic evolution, southeastern Klamath Mountains

Rich, 1977, Pennsylvanian paleogeography, western United States

Ripperdan and Kirschvink, 1989, Did Siberia play a role in the assembly of the North American western margin?

Rogers and others, 1974, Paleozoic and Lower Mesozoic volcanism and continental growth, western United States

Ross, 1977, Ordovician paleogeography of the western United States

Ross and Ross, 1983, Late Paleozoic accreted terranes, western North America

Rouer and Lapierre, 1989, Comparison between two Palaeozoic island-arc terranes, eastern Klamath and northern Seirra

Roure, 1981, Tectonique des chaines de l'Oregon occidental

Roure, 1982, Tectonique majeure du Jurassique supériere, Nord-Est de l'Oregon

Roure, 1983, Déformations liasiques, Blue Mountains et la chaine des Klamath

Roure, 1983, Les effets de l'orogenèse névadienne dans la chaîne des Klamath

Roure, 1983, Vergence and tectonic history of Klamath Mountains

Roure, 1984, Une coupe geologique de Golconda au Pacifique

Roure and Sosson, 1986, Late Jurassic collision between a composite exotic block and North America

Rubin and others, 1990, Cordilleran mid-Paleozoic volcano-plutonic complexes, evidence for convergent 
margin tectonism

Rubin and others, 1989, Evolution and tectonic setting of mid-Paleozoic arc basement, North American Cordillera

Saleeby, 1981, Accretion and arc evolution, Mesozoic Sierra Nevada

Saleeby, 1983, Accretionary tectonics, North American Cordillera

Saleeby and Busby-Spera, 1992, Early Mesozoic tectonic evolution, western U.S. Cordillera

Saleeby and Harper, 1993, Tectonic relations between Galice Formation and Condrey Mountain Schist

Savage and Boucot, 1977, Early Middle Devonian orogeny, northern California and southeast Alaska

Schwab, 1971, Geosynclinal compositions and new global tectonics

Schweickert and Snyder, 1981, Paleozoic plate tectonics, Sierra Nevada and adjacent regions

Seyfert, 1968, Continental accretion, Paleozoic and Mesozoic

Sharp and Wright, 1981, Jurassic metavolcanic sequences, western Sierra-Klamath provinces

Silberling, 1973, Geologic events during Permian-Triassic time, Pacific margin

Silberling and Jones, 1982, Tectonic significance of Permian-Triassic strata, northwestern Nevada and northern California

Stewart, 1991, Latest Proterozoic and Cambrian rocks of western United States - An overview

Stone and others, 1993, Pliocene-Pleistocene sedimentary tectonic history of NW California

Thompson and others, 1988, Correlation of melange terranes, Klamath Mts

Tomlinson and Barnes, 1991, Correlation of Rattlesnake Creek and Western Hayfork terranes, California to Oregon

Tozer, 1994, Tectonic and structural implications of the Cambrian Trinity plagiogranite

Wallin, 1993, Sonomia revisited: Western Canadian provenance of eastern Klamath and northern Sierra Nevada terranes

Wallin,1999, Overview of a mid-Paleozoic intraoceanic convergent margin, eastern Klamath Mountains

Wallin and Gehrels, 1995, Denudation of the Trinity terrane and timing of siliclastic sedimentation of the Yreka terrane

Wallin and others, 1992, Early Paleozoic tectonics and sedimentation, Yreka and Trinity terranes

Wallin and others, 2000, Provenance of the Antelope Mountain Quartzite, Yreka terrane; evidence for large-scale displacement along the North American Cordilleran margin

Wilson and others, 1991, Mesozoic evolution of exotic terranes and marginal seas

Worrall, 1979, Evolution of Franciscan-Klamath-Great Valley junction

Wright, 1979, Tectonic correlation, south-central Klamath Mountains and Sierra Nevada foothill belt

Wright, 1980, Paleotectonic setting, Hayfork terrane

Wright, 1982, Permo-Triassic accretionary subduction complex, southwestern Klamath Mountains

Wright and Fahan, 1988, Jurassic orogenesis; metamorphism and thrust faulting in active arc environment

Wright and Miller, 1986, Expanded view of Jurassic orogenesis

Wright and Sharp, 1981, Regional tectonic correlations, Klamath Mountains-Sierra Nevada provinces

Wright and Wyld, 1985, Multi-stage serpentinite matrix melange; Rattlesnake Creek terrane

Wyld and Wright, 1985, Galice basin and its ophiolitic and serpentinite basement

---1993, Is Rattlesnake Creek terrane out of place with respect to other terranes

Yule and Saleeby, 1993, Extended oceanic lithosphere; basement and wallrocks for Rogue-Chetco oceanic arc

Yule and others, 1992, Correlation of basement terranes across Josephine inter-arc basin

Yule and others, 1994, Geochemistry of Rattlesnake Creek terrane fragment within Western Jurassic belt

GEOCHEMISTRY AND PETROLOGY OF ARC AND OTHER ROCKS

Barker and others, 1977, Geochemistry of Devonian island-arc and intrusive rocks, West Shasta District

Barker and others, 1979, Geochemistry of Devonian island-arc and intrusive rocks, West Shasta District

Barnes and others, 1995, Geochemical compositions of metavolcanic and metasedimentary rocks

Bird and Bassett, 1980, Terrestrial osmium-iridium-ruthenium alloys, evidence for a deep mantle history

Brouxel, 1984, Basaltes de Trinity et leur complexe filonien; bassin marginal au Devonien dans les 
Klamath orientales

Brouxel and others, 1989, Magma types, Paleozoic island arc-marginal basin system

Brouxel and others, 1989, Upper Jurassic mafic magmatic rocks, eastern Klamath Mountains: arc built on young continental crust

Brouxel and others, 1987, Deep layers of Paleozoic arc, Copley-Balaklala volcanics

Brouxel and others, 1988, Early Paleozoic island-arc-back-arc basin system, Eastern Klamath Mountains

Brouxel and Lapierre, 1984, La serie basaltique de Trinity temoin de l'existence d'un bassin marginal au Devonian moyen

Brouxel and Lapierre 1985, Un bassin marginal devonien dans les Klamath orientales: le cortege ophiolitique de Trinity

Condie and Snansieng, 1971, Petrology and geochemistry, Duzel and Gazelle Formations

Cridland and Goles, 1996, Geochemical features, origin and tectonic significance of some rodingites

Donato, 1991, Back-arc basin metabasaltic complex, southwestern Oregon

Donato and others, 1994, Detrital clinopyroxene chemistry, key to Middle Jurassic volcanism

Ernst, 1987, Rock of apparent komatiitic affinities, Sawyers Bar area

Ernst, 1993, Dike/ sill sequences of contrasting age ranges, Sawyers Bar area

Ernst, 1999, Mesozoic petrotectonic development of the Sawyers Bar suprasubduction-zone arc

Ernst and others, 1990, Magnesian metavolcanic rocks, Western Triassic and Paleozoic belt

Ernst and Kolodny, 1997, Submarine and superimposed contact metamorphic oxygen isotopic exchange in an oceanic arc

Garcia, 1978, Identification of ancient volcanic arcs

Garcia, 1982, Rogue River island-arc complex, southwest Oregon

Garcia and Jacobson, 1979, Crystal clots, amphibole fractionation and evolution of calc-alkaline magmas

Harper, 1999, Synorogenic Late Jurassic calc-alkaline to intrusives in western Klamath terrane

Helming, 1966, Petrology of Rogue Formation

Johnson, 1980, Geochemical variations in ancient island arc, SW Oregon

Lapierre, 1983, Andesites riches en magnesium: temoins d'un arc insulaire devonien dans les Klamaths orientales

Lapierre and Cabanis, 1985, Caracterisation d'une serie tholeitique d'arc d'age Paleozoique, Klamaths orientales

Lapierre and others, 1983, Two Paleozoic island arcs, eastern Klamaths

Lapierre and others, 1985, Early Devonian volcanism, eastern Klamaths

Lapierre and others, 1985, Paleozoic and Mesozoic volcanism, eastern Klamaths

Lapierre and others, 1986, Paleozoic and Mesozoic evolution, eastern Klamaths

Lapierre and others, 1987, Paleozoic and Lower Mesozoic magmas, eastern Klamaths

Leikam, and others, 2002, New pillow lava and dike localities, Elk River area

Price and others, 2001, Newly discovered sheeted dike complex on Elk River, SW Oregon

Martin, 1989, Le volcanisme permien d'arc insulaire des Klamath

Martin and others, 1985, Paleozoic and Mesozoic volcanism, Klamath Mountains

Martin and others, 1984, Présence d'un arc insulaire permien dans les Klamath orientales

Mortimer, 1986, Late Triassic, arc-related, potassic igneous rocks

Potter and Grunder, 1992, Geochemical relationships, early Paleozoic igneous rocks, Yreka and Trinity terranes

Potter and Scheidegger, 1973, Paleozoic keratophyre and spilite, Gazelle-Callahan area

Potter and others, 1976, Magma types, early Paleozoic altered volcanic rocks

Potter and others, 1975, Magma types in Paleozoic keratophyres and spilites, Gazelle area

Renne and Carmichael, 1984, Intra-arc ultrabasic volcanism, Permian limburgites of eastern Klamath Mountains

Riley and Coleman, 1987, Petrogenetic evolution of Rogue Formation, submarine volcanic rocks of Western Jurassic belt

Rogers, 1966, Geochemical significance of source of graywackes, Oregon and Washington

Riley, 1988, Evolution of Late Jurassic island arc, Rogue Formation

Rouer and others, 1989, Devonian silicic arc magmatism in Sierra Nevada and Klamath Mountains 


\section{GEOPHYSICAL RESEARCH}

Paleomagnetism

Achache and others, 1982, Paleomagnetism of Devonian Kennett Limestone

Alpers and others, 1999, Paleomagnetic reversal in Iron Mountain gossan

Beck, 1992, Significance of paleomagnetic results for the western conterminous United States

Bogen, 1984, Paleomagnetism of metavolcanic rocks, Galice Formation

Bogen, 1986, Paleomagnetism of Galice Formation, differential rotation of the eastern and western Klamath Mountains

Bogen, 1986, Reply on "Paleomagnetism of Upper Jurassic Galice Formation..." of the eastern and western Klamath Mountains"

Calderwood, 1991, No suspect terranes, case against paleomagnetic data

Fagin and Gose, 1983, Paleomagnetic data, Redding section

Harper and Park, 1986, Comment on "Paleomagnetism of Upper Jurassic Galice..."

Irwin and others, 1984, Paleomagnetism in Klamath Mountains

Magill and Cox, 1981, Post-Oligocene rotation, western Cascade Range and Klamath Mountains

Mankinen and others, 1985, Paleomagnetic constraints on accretionary history of Klamath Mountains

Mankinen and Irwin, 1982, Paleomagnetics of Cretaceous and Tertiary sedimentary rocks

Mankinen and Irwin, 1990, Review of paleomagnetic data from Klamath Mountains, Blue Mountains, and Sierra Nevada

Mankinen and others, 1982, Tectonic rotation of eastern Klamath terrane

Mankinen and others, 1984, Tectonic rotations suggested by paleomagnetic studies, eastern Klamath terrane

Mankinen and others, 1984, Implications for tectonic history of eastern Klamath and related terranes

Mankinen and others, 1988, Paleomagnetic results, Shasta Bally plutonic belt

Mankinen and others, 1988, Paleomagnetic study of eastern Klamath terrane

Mankinen and others, 1996, Far-travelled Permian chert of the North Fork terrane

Mankinen and others, 2002, Concordant paleolatitudes for Neoproterozoic ophiolitic rocks of Trinity Complex

Renne, 1986, Permian to Jurassic tectonic evolution, eastern Klamath Mountains

Renne, 1988, Structural chronology, oroclinal deformation, and tectonic evolution

Renne and Scott, 1986, Comment on "Paleomagnetism of Upper Jurassic Galice..."

Renne and others, 1988, Multicomponent paleomagnetic data, Nosoni Formation; cratonic Permian primary directions with Jurassic overprints

Renne and others, 1986, Multicomponent paleomagnetic data, eastern Klamaths; cratonic Permian directions with secondary Middle Jurassic overprints

Schultz, 1983, Paleomagnetism in Klamath Mountains

Schultz and Levi, 1981, Paleomagnetism of Hornbrook Formation; implications for tectonic rotation

Schultz and Levi, 1983, Paleomagnetism of Middle Jurassic plutons

Scott and others, 1985, Paleomagnetism of Nosoni Fm. ignimbrite and implications of accretionary models of Eastern Klamath belt

Simpson and Cox, 1977, Paleomagnetic evidence for tectonic rotation of the Oregon Coast Range

\section{Aeromagnetic and related surveys}

Balsley and others, 1960, Aeromagnetic map of Kerby and part of Grants Pass quadrangles

Blakely, 1986, Maps showing aeromagnetic data and interpretation of Medford $1^{\circ}$ by $2^{\circ}$ quadrangle

Blakely and others, 1985, Tectonic setting of southern Cascade Range, interpreted from magnetic and gravity fields

Chase, 1988, Aeromagnetic map of Weed quadrangle

Griscom, 1972, Aeromagnetic survey and interpretation, Salmon-Trinity Alps primitive area

Griscom, 1977, Aeromagnetic and gravity interpretation, Trinity ophiolite complex

Griscom, 1984, Magnetic interpretation, Josephine Peridotite

Griscom and others, 1993, Significance of magnetic and gravity data across northern California

Irwin and Bath, 1962, Magnetic anomalies and ultramafic rock, northern California

Jachens and Elder, 1983, Aeromagnetic map and interpretation of geophysical data, Condrey Mountain Roadless Area

Nelson, 1960, Serpentine delineation by mapping associated magnetic anomalies 
U.S. Geological Survey, 1982, Aeromagnetic map of Condrey Mountain area

Western Geophysical Company of America, 1981, Airborne gamma-ray spectrometer and magnetometer survey, Redding quadrangle

---1981, Airborne gamma-ray spectrometer and magnetometer survey, Weed quadrangle

---1981, Airborne gamma-ray spectrometer and magnetometer survey, Medford quadrangle

Young, 1989, Aeromagnetic map, Redding $1^{\circ}$ by $2^{\circ}$ quadrangle

\section{Gravity}

Blank, 1964, Regional gravity survey in southwestern Oregon

Blank, 1965, Regional gravity survey in SW Oregon--Preliminary results

Blank, 1966, Features of Bouguer gravity field, southwestern Oregon

Bruemmer and Kays, 1965, Gravity models for peridotite injection and local metamorphism along north-northeast-trending zones, southwest Oregon

Chapman, 1966, Gravity field in northern California

Griscom, 1973, Bouguer gravity map, Redding Sheet

Griscom, 1980, Klamath Mountains Province

Kays and Bruemmer, 1963, Gravity and petrographic investigation along zones of local metamorphism, SW Oregon

Kays and Bruemmer, 1964, Gravity field over zones of major tectonism, southwest Oregon

Kays and Bruemmer, 1965, Gravity and petrographic investigations along zones of local metamorphism, southwest Oregon

Kim, 1974, Gravity investigation, Weed Sheet

Kim and Blank, 1973, Bouguer gravity map, Weed Sheet

LaFehr, 1966, Gravity in eastern Klamath Mountains

\section{Seismic refraction}

Fuis and Zucca, 1984, Geologic cross section, northeastern California, seismic refraction

Fuis and others, 1987, Geologic interpretation, seismic-refraction results, northern California

Zucca and others, 1986, Crustal structure of northern California

Seismicity

California Department of Water Resources, 1964, Crustal strain and fault movement investigation, faults and earthquake epicenters

Jennings and Saucedo, G. J., 1994, Fault activity map of California and adjacent areas

Niazi, 1964, Seismicity, northern California and western Nevada

Treasher, 1939, Earthquakes in Oregon, 1846-1938

Uhrhammer, 1991, Northern California seismicity

\section{ISOTOPIC GEOCHRONOLOGY}

Bird and others, 1999, Osmium and lead isotopes of rare OsIrRu minerals: from core-mantle boundary region?

Cotkin and Armstrong, 1987, Rb/Sr age, geochemistry, and tectonic significance of blueschist, Skookum Gulch

Cotkin and Grove, 1992, ${ }^{40} \mathrm{Ar} /{ }^{39} \mathrm{Ar}$ evidence of early Paleozoic subduction-zone metamorphism

Curtis and others, 1958, Age determination of granitic rocks, potassium-argon method

Dick, 1973, K-Ar dating of intrusive rocks, Josephine peridotite and Rouge Formation west of Cave Junction

Donato and Lanphere, 1992, Geochronology of selected amphibolites

Fahan, 1982, Geology and geochronology, part of Hayfork terrane

Fahan and Wright, 1983, Plutonism, volcanism, folding, regional metamorphism and thrust faulting; aspects of a major Middle Jurassic orogenic event

Fiebelkorn and others, 1983, Index to K-Ar determinations, Oregon

Frost and others, 2002, Nd and Sr isotopic data from Bear Mountain intrusive complex

Gray and McKee, 1981, New K-Ar dates from Wild Rogue Wilderness

Gehrels and Miller, 2000, Detrital zircon study of upper Paleozoic strata, eastern Klamath terrane 
Hacker and others, 1993, New geochronologic constraints on Early, Middle, and Late Jurassic orogenesis Haessig and others, 1987, Early Cambrian tonalite-plagiogranite, Yreka-Callahan-Gazelle area Harper and Saleeby, 1980, Zircon ages of Josephine Ophiolite and lower Coon Mountain Pluton Harper and others, 1986, Isotopic age of the Nevadan orogeny in western Klamath Mountains Helper and others, 1988, U-Pb and K-Ar age constraints for Late Jurassic-Early Cretaceous deformation Hopson and Mattinson, 1973, Ordovician and Late Jurassic ophiolitic assemblages, Pacific northwest 57. Kelley and others, 1987, Radiometric ages, Weed Quadrangle

Lanphere and Irwin, 1965, Carboniferous isotopic age, Salmon and Abrams schists

Lanphere and Irwin, 1966, Isotopic age of Salmon and Abrams Schist

Lanphere and Irwin, 1967, Age of metamorphism, Abrams Mica Schist.

Lanphere and others, 1975, Early Cretaceous metamorphic age, South Fork Mountain Schist

Lanphere and others, 1978, Early Cretaceous metamorphic age, South Fork Mountain Schist

Lanphere and others, 1968, Isotopic age of Nevada orogeny and older plutonic and metamorphic events

Lanphere and others, 1969, Geochronology of crystalline rocks, Klamath Mountains

Lewison, 1983, Fission track ages of two plutons, central Klamath Mountains

Mattinson and Hopson, 1972, Paleozoic ages, ophiolitic complexes in Washington and northern California

Mattinson and Hopson, 1972, Paleozoic ophiolitic complexes, Washington and northern California

Meibom and Frei, 2002, Evidence for an ancient osmium isotopic reservoir in Earth

Meibom and Frei, 2002, Correction [re evidence for an ancient osmium isotopic reservoir]

Metcalf and others, 1999, Trace element and $\mathrm{Nb}-\mathrm{Sr}-\mathrm{Pb}$ isotopic data from Silurian Bonanza King cmplx

Miller and Saleeby, 1987, Detrital zircon studies of Galice Formation; common provenance of strata overlying Josephine ophiolite and Rogue arc

Miller and Saleeby, 1989, Proterzoic detrital zircon from Bragdon Formation

Miller and Saleeby, 1991, 2.1 Ga detrital zircon from Tethyan belt melange, E. Hayfork terrane; continent-sourced sand in an oceanic subduction complex

Miller and Saleeby, 1994, U-Pb geochemistry, detrital zircon from Galice Fm.

Miller and others, 1988, Provenance of the Carboniferous Bragdon Formation

Saleeby, 1984, Pb/U zircon ages, Rogue River area, Western Jurassic belt

Saleeby, 1987, Discordance in Pb/U zircon ages, Sierra Nevada and Klamath Mountains

Saleeby, 1990, Geochronologic and tectonostratigraphic framework, Sierran-Klamath ophiolitic assemblages

Saleeby and others, 1984, $\mathrm{Pb} / \mathrm{U}$ zircon ages, thrust plates of Klamath Mountains and Coast Ranges

Slawson, 1983, Isotopic composition of lead from a paleo-island arc

Wallin, 1986, Eocambrian-Early Cambrian plutonic rock, Eastern Klamath province

---1988, Provenance of Lower Paleozoic sandstones, eastern Klamath Mountains

---1989, Timing and sequence of early Paleozoic sedimentation, Yreka-Callahan terrane

---1989, Xenocrystic Precambrian zircon in Lower Cambrian tonalite, eastern Klamath Mountains

---1990, Xenocrystic Precambrian zircon in Lower Cambrian tonalite, eastern Klamath Mountains

Wallin and others, 1991, Amalgamation of Cambrian and Ordovician terranes along pre-Late Silurian suture, eastern Klamath Mountains

---1991, Early Paleozoic magmatism, eastern Klamath Mountains

Wallin and others, 1988, Early Paleozoic magmatic events, eastern Klamath Mountains

Wright, 1981, Geology and U-Pb geochronology, Western Paleozoic and Triassic Subprovince

\section{MINERAL DEPOSITS--METALLIC \\ Chromium}

Albers, 1984, Introduction, chromite deposits in Josephine Peridotite

Albers, 1984, Chromite in Low Plateau area, Del Norte County

Allen, 1938, Chromite deposits in Oregon

Allen, 1941, Chromite deposits of California

Boalich, 1918, Manganese and chromium

Bradley and others, 1918, Manganese and chromium in California

Cornwall, 1981, Chromite deposits, Seiad Valley and Scott Bar quadrangles

Correa, 1974, Exploration for alpine-type chromite in California

Diller, 1921, Chromite in Klamath Mountains 1-35.

Ellis, 1977, Podiform chromite in Josephine Peridotite 
Harder, 1910, Chromite deposits, western and central California

Johnston, 1936, Nodular, orbicular, and banded chromite, northern California

Lipin and others, 1983, Emma Bell deposit, Siskiyou County, a low-grade source

Maxson, 1933, Contact conditions of chromite deposits in serpentine

Newberry, 1874, Occurrence of chromic iron and serpentine in California

O'Farrell, 1933, Explanation of chromite ore, Klamath River district

Page and Johnson, 1977, Chromite resources of podiform deposits and exploration for concealed deposits, Medford-Coos Bay quadrangles

Ramp, 1957, Lower Illinois River chromite district

Ramp, 1957, Southwestern Oregon chromite deposits

Ramp, 1961, Chromite in southwestern Oregon

Rynearson and Smith, 1940, Chromite deposits in Seiad quadrangle

Stevens, 1944, Composition of chromites of Western Hemisphere

Swartley, 1939, Features of west coast chromite deposits

U.S. Geological Survey, 1943, Chromite deposits of McGuffy Creek area, Siskiyou County

U.S. Geological Survey, 1943, Fairview and Ladd chromite deposits, Siskiyou County

Wells and Cater, 1950, Chromite deposits of Siskiyou County

Wells and Hawkes, 1965, Chromite deposits of Shasta, Tehama, Trinity, and Humboldt Counties

Wells and others, 1946, Chromite deposits of Del Norte County

Wells and others, 1940, Chromite deposits in Sourdough area, Curry County, and Briggs Creek area, Josephine County

Wells and others, 1949, Chromite deposits near Seiad and McGuffy Creeks, Siskiyou County

Wynn and Hasbrouck, 1980, Geophysical studies of chromite deposits, Josephine ultramafic complex

Wynn and Hasbrouck, 1984, Geophysical studies of chromite deposits, Josephine Peridotite

\section{Copper}

Albers, 1958, East Shasta copper-zinc district, Shasta County

Albers, 1959, Soda metasomatism, East-Shasta copper-zinc district

Aubury, 1902, Copper resources of California

Aubury, 1908, Copper resources of California

Aubury, and others, 1908, Copper resources of California

Averill, 1935, Shasta County copper belt

Campbell, 1907, Copper of Shasta County

Diller, 1902, Copper in northern California

Diller, 1903, Copper deposits of Redding region

Eric, 1948, Tabulation of copper deposits of California

Forstner, 1907, Copper in Shasta County

Forstner, 1908, Genesis of copper ores in Shasta County

Graton, 1910, Copper in Shasta County

Hausmann and Kruttschnitt, 1908, Copper resources of Shasta, Siskiyou, Del Norte, and Trinity Counties

Hundhausen, 1952, Shamrock copper-nickel mine, Jackson County

Jenkins and others, 1948, Copper in California

Johnston, 1935, Copper in Trinity County

Kay, 1908, Copper prospects, Riddles quadrangle

Kellogg, 1928, Origin of copper in southwestern Oregon

Martin, 1908, Mining and smelting, Shasta copper belt

Martin, 1910, East side of Shasta copper belt

O'Shaughnessy, 1899, Copper resources of California

Packard, 1909, Copper mines and smelteries, Shasta County

Reid, 1908, Copper belt of California

Seager, 1940, Shasta copper belt

Shenon, 1933, Copper deposits, Squaw Creek and Silver Peak districts, and at Almeda mine, with notes on Pennell and Farmer and Banfield prospects

Tucker, 1924, Copper resources of Shasta County 
Albers, 1961, Gold deposits in French Gulch-Deadwood district

Aubury and others, 1910, Gold dredging in California

Averill, 1933, Gold deposits of Redding and Weaverville quadrangles

Averill, 1938, Gold dredging in Shasta, Siskiyou, and Trinity Counties

Averill, 1941, Dragline dredging in Siskiyou County

Averill, 1946, Placer mining for gold in California

Bartley, 1972, Unusual gold occurrence from Douglas County

Black, 1967, Handbook for underwater prospectors

Boggs and Baldwin, 1970, Placer gold in Sixes River, southwestern Oregon

Brooks and Ramp, 1968, Gold and silver in Oregon

Campbell, 1908, La Grange hydraulic mine

Chase, 1873, Lower Klamath River mines, remarkable gravel deposits

Clark, 1970, Gold districts of California

Clark, 1974, Gold in Klamath Mountains

Danielson and Silberman, 1987, Geologic setting of lode gold deposits, Redding 1 X 2 degree quadrangle

---1988, Geologic setting and characteristics of lode-gold deposits, Redding 1 x 2 degree quadrangle

Danielson and others, 1990, Age of mineralization of gold-quartz veins at Reid mine, Eastern Klamath terrane

Diller, 1908, Placer mines of Riddles quadrangle

Diller, 1911, Auriferous gravels of Trinity River basin

Diller, 1914, Auriferous gravels in Weaverville quadrangle

Doolittle, 1908, Gold dredging in California

Dunn, 1894, Auriferous conglomerate in California

Elder, 1991, Tectonic control of lode gold deposits, Quartz Hill

Elder and Cashman, 1991, Tectonic control of lode gold deposits, Quartz Hill

Elder and Cashman, 1992, Tectonic control and fluid evolution, Quartz Hill lode gold deposits

Elder and Cashman, 1993, Tectonic control and fluid evolution, Quartz Hill lode gold deposits

Fairbanks, 1895, Auriferous conglomerate in California

Ferguson, 1914, Gold lodes of Weaverville quadrangle

Ferguson, 1915, Pocket deposits of Klamath Mountains

Ferrero, 1990, Liberty gold mining district, Siskiyou County

Hackman, 1971, Mineralization at the Siskon Mine, Siskiyou County

Haley, 1923, Gold placers of California

Hall, 1893, Ancient gravels, Siskiyou County

Hamilton, 1979, Mining history made on Coffee Creek, Trinity County

Hershey, 1899, Origin and age, gold "pocket" deposits

Hershey, 1897, A "pocket" horizon, Trinity County

Hershey, 1899, Upper Coffee Creek mining district

Hershey, 1900, Gold-bearing lodes, Sierra Costa Mountains

Hershey, 1910, Origin of gold "pockets"

Hotz, 1971, Geology of lode gold districts

Kay, 1908, Gold-quartz mines, Riddles quadrangle

Kellogg, 1919, Placer mining in Oregon

Kellogg, 1928, Auriferous gravels of southwest Oregon

Kellogg, 1928, Llano de Oro placers, Waldo district

Kramm, 1912, Geology of Harrison Gulch, Shasta County

Leach, 1899, Fineness of California gold

Libbey, F. W., 1967, Almeda mine, Josephine County

Lowell, 1942, Paragenesis of gold and copper ores, southwestern Oregon

MacDonald, 1986, Gold and silver telluride mineralization, Reid Mine, Shasta County

MacDonald, 1910, Weaverville-Trinity Center gold gravels, Trinity County

MacDonald, 1913, Gold lodes of Carrville district, Trinity County

Moore and Silver, 1968, Gold distribution on sea floor off Klamath Mountains

Ohlin, 1988, The "terrane" to gold; correlation of Klamath Mountains and Sierra Nevada terranes

Oregon Department of Geology and Mineral Industries, 1954, Oregon's gold placers

Page and others, 1983, Map showing characteristics of lode gold, Medford $1^{\circ}$ by $2^{\circ}$ quadrangle

Pardee, 1933, Placer deposits, western United States 
Ramp, 1960, Gold placer mining, southwestern Oregon

Ramp and others, 1975, Oregon's gold potential

Shenon, 1933, Geology of Robertson, Humdinger, and Robert E. gold mines, southwestern Oregon

Silberman and Danielson, 1991, Setting, characteristics, and geochemistry of gold-bearing quartz veins, Redding 1 X 2 degree quadrangle

Silberman and Danielson, 1993, Gold-bearing veins, Redding 1 X 2 degree quadrangle

Silberman and others, 1987, Characteristics and geochemistry, gold-bearing quartz veins in Redding $1 \mathrm{X}$ 2 degree quadrangle

Silberman and others, 1991, Regional geochemical signatures of lode Au and Cu deposits, western half of the Redding $1^{\circ} \times 2^{\circ}$ quadrangle

Silberman and others, 1993, Delineation of terranes favorable for lode gold deposits, western half of Redding 1 X 2 degree quadrangle

Siskiyou County Historical Society, 1957, Guidebook to Siskiyou's gold fields

Stopps, 1937, Esterly placer mine

Thevenet, 1860, Sur les gisements auriferes et platiniferes de l'Oregon

Thompson, 1957, King Solomon mine, Siskiyou County

Treasher, 1937, Placers of the upper Applegate, Jackson County

Tucker, 1922, Gold lodes of East Fork mining district, Trinity County

Turner, 1903, Cretaceous auriferous conglomerate, Cottonwood mining district, Siskiyou County

White, 1939, Almeda mine

Wilson, 1854, Gold regions of California

Campbell, 1906, Iron ore of Shasta County

Iron

Diller, 1903, Iron ores of Redding quadrangle

Lamey, 1948, Hirz Mountain iron-ore deposits, Shasta County

Lamey, 1948, Shasta and California iron-ore deposits

Prescott, 1908, Magnetite ores of Shasta County

Goodwin, 1957, Lead and zinc in California

$\underline{\text { Lead and zinc }}$

Manganese

Appling, 1958, Manganese deposits, southwestern Oregon

Brown, 1942, Manganese, southern Oregon coastal region

Jenkins and others, 1943, Manganese in California

Kellogg, 1927, Manganese in southwestern Oregon

Libbey and others, 1942, Manganese in Oregon

Taliaferro and Hudson, 1943, Genesis of manganese deposits, Coast Ranges of California

Trask and others, 1943, Manganese deposits of California

Trask and others, 1950, Manganese deposits of California

Trengove, 1960, California manganese deposits

Massive sulfide

Albers, 1953, Geology and ore deposits, Afterthought mine, Shasta County

Albers, 1985, Introduction, special issue, massive sulfide deposits, West Shasta district

---1985, Brick Flat massive sulfide body, Iron Mountain cluster, West Shasta district

Albers and Bain, 1985, Regional setting and critical features, West Shasta district

Alpers and others, 1991, Storage of metals and acidity by iron-sulfate minerals asssociated with acid mine waters, Iron Mountain

Averill, 1931, Mountain Copper Company, Ltd., cyanide treatment of gossan

Averill, 1938, Mountain Copper Company, Ltd., cyanide treatment of gossan

Bence, 1984, REE systematics of West Shasta metavolcanic rocks; petrogenesis and hydrothermal alteration

Bence and Taylor, 1985, Rare earth element systematics of West Shasta metavolcanic rocks; petrogenesis and hydrothermal alteration

Botinelly and others, 1985, Trace elements in disseminated sulfides, magnetite, and massive sulfides, 
West Shasta district

Boyle, 1914, Geology and ore deposits, Bully Hill mining district

Boyle, 1915, Geology and ore deposits, Bully Hill mining district

Casey, 1979, Geology and geochemistry of mineralization and alteration, West Shasta Cu-Zn district

Casey and Taylor, 1978, Stable isotopic investigation of hydrothermal ore fluids, massive sulfide deposits of West Shasta Cu-Zn district

Casey and Taylor, 1982, Oxygen, hydrogen, and sulfur isotope geochemistry, West Shasta Cu-Zn district

Cramer, 1982, Petrography, fluid inclusion, and light stable isotope study, Gray Eagle Cu-Au massive sulfide deposit, Siskiyou County

Cramer and Taylor, 1983, Oxygen, hydrogen and sulfur isotope geochemistry, Gray Eagle Cu-Zn-Au deposit, Siskiyou County

Cunningham, 1979, Geology and geochemistry of massive sulfide deposit and associated volcanic rocks, Blue Creek district, southwestern Oregon

Danielson and Bergk, 1993, From black smokers to acid mine drainage

Derkey, 1980, Silver Peak volcanogenic massive sulfide

Derkey, 1981, Silver Peak volcanogenic massive sulfide

Doe and others, 1985, Plumbotectonics of West Shasta mining district

Eastoe, 1992, Zoned depletion of base metals beneath volcanogenic massive sulfide deposits

Eastoe and Nelson, 1988, Permian Kuroko-type hydrothermal system, Afterthought-Ingot area

Fifarek, 1992, Modification of Banfield and Rowley Besshi-type volcanogenic massive sulfide systems, SW Oregon

Foster, 1980, Iron Mountain Mine, West Shasta copper-zinc district

Fredericks, 1980, Volcanic lithofacies and massive sulfide mineralization, East Shasta District

Friedrich and Hawkes, 1967, Mercury haloes as prospecting indicators at base-metal deposits, West Shasta district

Gronewold, 1983, Geochemistry of Grey Eagle volcanogenic massive sulfide deposit, Siskiyou County

Gronewold and Taylor, 1983, Major and trace element zonation, Gray Eagle Cu-Zn deposit

Gronewold and others, 1983, Au-bearing gossan, Gray Eagle Cu-Zn massive sulfide deposit

Gustin and Eastoe, 2000, Permian Kuroko-type volcanogenic massive sulfide deposits, Bully Hill area

Hassemer, 1983, Geochemistry, West Shasta district

Hershey, 1915, Iron Mountain, Shasta County

Horton and Smith, 1985, Electrical geophysics of massive sulfide deposits and host rocks, West Shasta copper-zinc district

Horton and others, 1985, Electrical geophysics of massive sulfide deposits and host rocks, West Shasta copper-zinc district

Howe, 1985, Massive sulfide ore, West Shasta district

Hundhausen, 1947, Blue Ledge copper-zinc mine, Siskiyou County

Hutchinson, 1973, Volcanogenic sulfide deposits, metallogenic significance

Kett, 1947, Fifty years of operation by Mountain Copper Company, Ltd., Shasta County

Kinkel, 1955, Control of ore deposition, West Shasta copper-zinc district

Kinkel and Albers, 1949, Massive sulfide deposits at Iron Mountain, Shasta County

Kinkel and Albers, 1951, Massive sulfide deposits at Iron Mountain, Shasta County

Kinkel and Hall, 1951, Shasta King mine, Shasta County

Kinkel and Hall, 1952, Mammoth mine, Shasta County

Kinkel and others, 1956, Geology and base-metal deposits, West Shasta copper-zinc district, Shasta County

Kistler and others, 1985, Rb-Sr, Sm-Nd, U-Pb, and K-Ar study of host rocks and ore minerals, West Shasta $\mathrm{Cu}-\mathrm{Zn}$ district

Koski, 1980, Volcanogenic massive sulfide deposits in ocean-crust and island-arc terranes

Koski, 1981, Volcanogenic massive sulfide deposits in ocean-crust and island-arc terranes

Koski and Derkey, 1981, Massive sulfide deposits in oceanic-crust and island-arc terranes, southwestern Oregon

Kuhns and Baitis, 1987, Turner Albright Zn-Cu-Ag-Au-Co massive sulfide deposit, Josephine County

Lapierre and others, 1985, Setting of Early Devonian Kuroko-type sulfide deposits, eastern Klamath Mountains, inferred by characteristics of associated island-arc volcanic rocks

Lindberg, 1985, Volcanogenic interpretation for massive sulfide origin, West Shasta district 
Nordstrom and others, 1991, Measurement of negative $\mathrm{pH}$ values and high metal concentrations in acidic mine waters from Iron Mountain

Raines and others, 1985, Near-infrared spectra of West Shasta gossans

Reed, 1984, Geology, wall-rock alteration, and massive sulfide mineralization, West Shasta district

Reed, 1977, Hydrothermal metasomatism and ore deposition in submarine volcanic rocks, West Shasta district

Sandberg, 1965, Geophysical survey, Iron Mountain mine, French Gulch quadrangle

Sanzolone and Domenico, 1985, Trace element content of gossans, West Shasta district

South, 1984, Mineralogy and geochemistry, Iron Mountain massive sulfide deposit

South and Taylor, 1985, Geochemistry and metal zonation, Iron Mountain mine, West Shasta district

Taylor and Cramer, 1983, Geochemistry of Gray Eagle Cu-Zn-Au deposit, Siskiyou County

Taylor and South, 1985, Systematics of hydrothermal alteration and massive sulfide deposition, West Shasta district

Washburne, 1982, Spectral induced polarization data and measurements, West Shasta copper-zinc district

Watkins and Stensrud, 1983, Age of sulfide ores, West Shasta and East Shasta districts

Witte, 1977, Massive sulfide deposits, Silver Peak District, Douglas County

Wood, 1987, Geology and geochemistry, Almeda mine, Josephine County

Zierenberg and others, 1988, Mineralization, alteration, and hydrothermal metamorphism, ophiolite-hosted Turner-Albright sulfide deposits

Aubury, 1903, Quicksilver resources of California

Mercury

Bradley, 1918, Quicksilver resources of California

Brooks, 1963, Quicksilver in Oregon

Forstner, 1903, Quicksilver resources of California

Hanks, 1884, Quicksilver

Kellogg, 1919, Cinnabar ore in Jackson County

Kellogg, 1927, Quicksilver in Gold Hill, Oregon

Putnam, 1974, Geology and geochemistry of mercury occurrences, Horse Creek area, Siskiyou County

Ransome and Kellogg, 1939, Quicksilver resources of California

Schuette, 1938, Quicksilver in Oregon

Swinney, 1950, Altoona quicksilver mine, Trinity County

Wells and Waters, 1934, Quicksilver deposits, southwestern Oregon

Nickel

Anonymous, 1982, Gasquet Mountain project reserves confirmed

Anonymous, 1982, Promisory outlook at Gasquet Mountain

Anonymous, 1982, Gasquet Mountain, a US metal laterite project

Benson, 1963, Pine Flat and Diamond Flat nickel-bearing laterite deposits, Del Norte County

California Department of Natural Resources, Division of Mines, 1954, Nickel in California

Chace and others, 1969, Applied geology at Nickel Mountain mine, Riddle

Clarke, 1888, Nickle ores from Oregon

Cumberlidge and Chace, 1968, Geology of Nickel Mountain mine, Riddle

Dole and others, 1948, Nickel-bearing laterite, southwestern Oregon

Durst, 1976, Mineralogical and chemical development, Nickel Mountain laterite deposit

Foose, 1992, Nickel; Composition of nickel-bearing laterites, southern Oregon and northern California

Hood, 1883, Nickel ore from Piney Mountain, Douglas County

Hotz, 1964, Nickeliferous laterites, southwestern Oregon and northwestern California

Hotz, 1966, Nickel resources of California

Kay, 1907, Nickel deposits of Nickel Mountain, Oregon

Ledoux, 1901, Oregon nickel prospects

Mason, 1949, Exploration of nickel-bearing laterite, Woodcock Mountain, Josephine County

Montoya and Baur, 1963, Nickeliferous serpentines, chlorites, and related minerals found in two lateritic ores

Oregon Department of Geology and Mineral Industries, 1953, Nickel Mountain Project

Oregon Department of Geology and Mineral Industries, 1970, Nickel-bearing stream sediments, 
southwestern Oregon

Pecora and Hobbs, 1942, Nickel deposit near Riddle, Douglas County

Pecora and others, 1949, Garnierite from the nickel deposits near Riddle

Ramp, 1978, Investigations of nickel in Oregon

Rice, 1956, Nickeliferous laterite, northwestern California

Routher, 1964, Nickeliferous laterites, southwestern California

Rowe and others, 1976, Nickel Mountain Mine, Riddle

Rudmann, 1970, Distribution and mineralization of nickel in saprolite ore, Nickel Mountain, Riddle

Schoenike, 1954, Nickel silicate deposit at Riddle, Oregon

Walker, 1955, Exploration of Riddle Mountain nickel deposits

\section{Platinum}

Carlson and others, 1986, Map showing distribution of platinum-group elements and gold, western half of Medford and part of adjacent Coos Bay 1 by 2 quadrangles

Gray and others, 1986, Platinum-group geochemistry of zoned ultramafic intrusives

Kellogg, 1922, Platinum in quartz veins, southwest Oregon

Kellogg, 1929, Platinum in southwestern Oregon

Logan, 1919, Platinum and allied metals in California

Page and others, 1975, Platinum group metals in ultramafic rocks, Medford-Coos Bay $2^{\circ}$ quadrangle

Page and others, 1985, Map showing geochemical characteristics of platinum-group elements and gold, Kalmiopsis Wilderness

Page and others, 1986, Platinum-group elements in podiform chromitites, California and Oregon

Ramp and Brooks, 1969, Platinum group metals in Oregon

Snetsinger, 197l, Platinum-metal nugget from Trinity County

Spencer, 197l, Platinum metals with heavy minerals in stream sediments of Klamath Mountains

\section{Silver}

Tucker, 1922, Silver lodes of South Fork mining district, Shasta County

Tucker, 1926, Silver lodes of South Fork mining district, Shasta County

\section{General and other}

Albers, 1965, Economic geology, French Gulch quadrangle

Albers, 1966, Economic deposits, Klamath Mountains

Albers, 1980, Metallic mineral deposits, California's tectonic framework

Albers, 1981, Lithologic-tectonic framework for metallogenic provinces, California

Allen, 1945, Vanadium-bearing black-sand deposit of middle Miocene age, Curry County

Averill, 1931, Economic geology, Shasta quadrangle

Averill, C. V., 1940, Economic geology of California and southern Oregon

California Division of Mines, 1957, California mineral production, 1956

Derkey, 1982, Geology of Silver Peak mine, Douglas County

Diller, 1904, Mining and mineral resources, Redding quadrangle

Diller and Kay, 1908, Mines of Riddle quadrangle

Diller and Kay, 1909, Mineral resources, Grants Pass quadrangle and bordering districts

Gustin and Eastoe, 1986, Geology and mineralization of Bully Hill area

Hollister, 1949, Shasta gold-silver district

Hutchinson and Albers, 1992, Metallogenic evolution of the Cordilleran region of western U.S.

Irwin and others, 1955, Geology, mineral resources, and mineral industry

Kellogg, 1921, Cobalt in Jackson County

Maxson, 1933, Economic geology of portions of Del Norte and Siskiyou Counties

Moore and Stephens, 1954, Uranium-bearing carbonaceous rocks, California and adjacent parts of Oregon and Nevada

O'Brien, 1943, Clerbus-Mae tungsten prospect, Trinity County

Oregon Department of Geology and Mineral Industries, 1951, Map showing principal mineral deposits of Oregon

Oregon Department of Geology and Mineral Industries, 1958, Map showing principal mineral deposits of Oregon

Page and others, 1982, Mineral resource potential map of Kalmiopsis Wilderness, southwestern Oregon 
Peterson, 1980, Metallogenetic maps of ophiolites, western United States

Peterson, 1984, Metallogenetic maps of ophiolite belts, western United States

Shenon, 1933, Geology and ore deposits of Takilma-Waldo district, including Blue Creek district

Silberman and others, 1994, Assessment of mineral resource potential, western half of Redding 1:250,000 quadrangle

Singer and others 1982, Mineral resource assessment of the Medford 1 by 2 degree quadrangle

Anderson, 1902, Ore deposits, Shasta County

County and district reports

Averill, 1933, Trinity County

Averill, 1935, Mines and mineral resources, Siskiyou County

Averill, 1939, Mineral resources, Shasta County:

Averill, 1941, Mineral resources, Humboldt County:

Averill, 1941, Mineral resources, Trinity County:

Brown, 1916, Mines and mineral resources--Shasta, Siskiyou, and Trinity Counties

Butler, and Mitchell, 1916, Geology and mineral resources, Curry County

Davidson, 1900, Register of mines and minerals, Siskiyou County

Diller, 1900, Bohemia mining region, western Oregon

Diller, 1905, Mineral resources, Indian Valley region

Diller, 1912, Mines and prospects, southwestern Oregon

Diller, 1914, Mineral resources, southwestern Oregon

Dittmar, 1899, Northern California's mines and minerals

Dittmar, 1902, Register of mines and minerals, Shasta County

Dunn, 1892, Siskiyou County

Dunn, 1892, Trinity County

Hamilton, 1922, California mineral resources and State Mining Bureau

Hobson, 1890, Siskiyou County

Hodson, 1892, Shasta County

Irelan, 1888, Humboldt, Shasta, Siskiyou, and Trinity Counties

Kinkel and others, 1954, Geologic maps of the Shasta copper-zinc district, Shasta County

Laizure, 1920, Trinity County

Laizure, 192l, Redding field division, and Del Norte, Humboldt, Shasta, Siskiyou, and Trinity Counties

Laizure, 1925, Del Norte County

Laizure, 1925, Humboldt County

Libbey, 195l, Geology and mineral resources, Douglas County

Logan, 1924, Shasta and Siskiyou Counties

Logan, 1925, Siskiyou County

Logan, 1926, Shasta County

Logan, 1926, Trinity County

Lowden, 1900, Register of mines and minerals, Trinity County

Lowell, 1916, Del Norte, Humboldt, and Mendocino Counties

Lydon, and O'Brien, 1974, Mines and mineral resources, Shasta County,

MacGregor, 1890, Del Norte, Humboldt, and Shasta Counties

Miller, 1890, Trinity County

O'Brien, 1943, Strategic minerals, Redding district

O'Brien, 1947, Mines and minerals, Siskiyou County

O'Brien, 1949, Trinity County

O'Brien, 1952, Mines and minerals, Del Norte County

O'Brien, 1965, Mines and minerals, Trinity County

O.D.G.M.I., 1943, Metal mines handbook, Jackson County

O.D.G.M.I., 1952, Metal mines handbook, Josephine County

Ramp, 1972, Geology and mineral resources, Douglas County

Ramp, 1975, Geology and mineral resources, Upper Chetco drainage

Ramp and Peterson, 1979, Geology and mineral resources, Josephine County

Shenon, 1933, Geology and ore deposits, Takilma-Waldo district

Stines, 1907, Coffee Creek mining district 
Storms, 1913, Trinity-Balaklala-Vulcan mines, Shasta County

Tischler and others, 1964, Geological survey of 1955-1961

Tucker, 1922, Shasta, Siskiyou, and Trinity Counties

Tucker, 1923, Shasta, Siskiyou, and Trinity Counties

Watts, 1892, Del Norte County

Wells, 1933, Chieftain and Continental Mines, Douglas County

Winchell, 1914, Petrology and mineral resources, Jackson and Josephine Counties

Yale, 1899, Mineral industry of California

Youngberg, 1974, Mount Reuben mining district, Josephine County

\section{MINERAL DEPOSITS--NONMETALLIC}

Asbestos

Laudermilk and Woodford, 1930, Soda-rich anthophyllite, Trinity County

Malone and others, 1962, Mount Eddy and Shasta View asbestos deposits, Siskiyou County

Wiebelt and Smith, 1959, Asbestos deposits in serpentine belt

Crawford, 1894, Coal--Trinity County

$\underline{\text { Coal }}$

Crawford, 1896, Coal--Trinity County

Diller, 1885, Coal in the Chico group

Anonymous, 1871, Diamonds in Trinity County

\section{Diamonds}

Hanks, 1870, Diamonds in California

Hill, 1972, Hunting diamonds in California

Kopf and others, 1990, Large diamonds in Trinity County

Turner, 1899, Occurrence and origin of diamonds in California

Volney, 1870, California diamonds

Diller, 1903, Limestone of the Redding district

Limestone

Evans, 1977, McCloud Limestone, South Gray Rocks area, Shasta County

Libbey, 1957, Limestone resources, Pacific Northwest

Logan, 1947, Limestone in California

Peterson and Mason, 1958, Limestone occurrence, western Oregon

Tucker, 1923, Limestone deposits of McCloud River, Shasta County

Other

Aubury, 1906, Structural and industrial materials of California

Hassemer and others, 1992, Analytical results and map, samples from Hayfork 30'X $1^{\circ}$ Quadrangle

Hassemer and others, 1992, Analytical results and map, samples from Garberville $30^{\prime} \mathrm{X} 1^{\circ}$ Quadrangle

Ramp, 1960, Quartz Mountain silica deposit, Oregon

Weber and Matthews, 1967, Barite in northern Shasta County

\section{SPECIFIC MINERALS}

Botto and Morrison, 1976, Josephinite, a unique nickel-iron

Brindley, 1969, Unit cell of magadiite

Dick and Gillete, 1976, Josephinite-specimens from the core?

Dunning and Cooper, 1987, Inesite from Hale Creek mine, Trinity County

Dunning and Cooper, 1995, Troilite from the Low Divide district, Del Norte County

Eakle, 1922, Massive Troilite from Del Norte County

Gude and Sheppard, 1969, Hydrous sodium silicate minerals, Trinity County

Gude and Sheppard, 1972, Silhydrite, $3 \mathrm{SiO}_{2} \mathrm{H}_{2} \mathrm{O}$, new mineral from Trinity County

Hewett and others, 1961, Tephroite in California manganese deposits

Landon, 1927, Romerite from California

Leavell, 1979, Josephinite in Josephine Peridotite, southwest Oregon

McAtee and others, 1968, Magadiite from Trinity County 
Prescott, 1908, Ilvaite from Shasta County

Sheppard and Gude, 1969, Rhodesite from Trinity County

Weathers, 1976, Geology, petrography and origin of josephinite

\section{ENVIRONMENTAL AND ENGINEERING}

Baldwin, 1993, Management of sediment, its effects on riparian habitat

De La Fuente and others, 1997, Effects of storms on slope and channel processes

De La Fuente and others, 2002, Does deforestation influence activity of deep-seated landslides

Beaulieu and Hughes, 1977, Land use geology, Jackson County

Bedrossian, 1991, Timber harvesting in granitic terrain, Grass Valley Creek

California Department of Water Resources, 1964, Ewing Project--Reconnaissance study

Coleman and Kruckeberg, 1999, Geology and plant life of the Klamath-Siskiyou Mountain region

Collins and Hicks, 1971, Engineering Geology in unstable region

Ferrero and others, 1992, Slope stability mapping

Ferrero and others, 1992, Faulting and large scale landslides, Siskiyou Mountains, Curry Country

Gamer, 1952, Construction geology of tunnel no. 12, S.P.R.R.--relocation around Shasta Dam reservoir

Gardner, 1946, Applied engineering geology, Shasta Dam

Haessig and others, 2002, Abandoned mine reclamation of sediment tailings at King Solomon Mine

Hicks and Collins, 1970, Engineering geology in forest road construction and logging practices

Hicks and Collins, 1971, Acceleration of mass movement by debris flow activity

Louderback, 1928, Geologic features, Kennett dam site

Nickell, 1942, Development and use of engineering geology

Rhoades, 1942, Petrographic and related information, Shasta and Friant aggregate and concrete

U.S. Bureau of Reclamation, 1965, Geology, Trinity Dam and powerplant

Vehrs, 1961, Landslide, Excavation Area 2, Trinity Dam

Walker and Bock, 1972, Treatment of high embankment dam foundations

Williams and others, 1982, Timber harvesting, geomorphic zones, and slope instability

Wisehart and Wagner, 1973, Slope stability and stream capture, Bluff Creek

\section{MISCELLANEOUS}

Bayne, 1950, Method of geologic mapping in Galice quadrangle

Chernosky, 1969, Metasomatic zoning at Tamarack Lake, Trinity County

Chernosky, 1975, Metasomatic zoning at Tamarack Lake, Trinity County

Dong and others, 1974, Limnology of Lake Shastina, Siskiyou County

Evoy, 1982, Complex mass movements, Little Rattlesnake Mountain

Gullixson and others, 1980, Igneous rocks near Marial, Rogue River

Harper and others, 1996, Cretaceous thermochronology of the western Klamath Mountains

Hershey, 1909, Black Diamond, Del Norte County

Hinds, 1930, Igneous geology, southern Klamath Mountains

Kimmel, 1977, Nutrient transfers associated with sedimention, Castle Lake

Klaseen and Ellison, 1974, Soil survey of Shasta County area

Libbey, 1963, Lest we forget

Merriam, 1945, Magmatic differentiation in gabbro sills near Ashland

Paulsen, 1987, Contributions of sediment dentrification to nitrogen cycle, Castle Lake

Pinto-Auso and Harper, 1985, Sedimentation, metallogenesis, and tectonic origin of basal Galice Formation overlying Josephine ophiolite

Rogers and McKay, 1972, Chemical evolution of geosynclinal material

Sanders, 1976, Carbon flux in sediment of Castle Lake

Schwindinger and Anderson, 1987, Low-pressure intrusion of gabbro into serpentinized peridotite

Tomlinson and Wright, 1986, Klamath-Sierran arc, a possible source for Permian volcaniclastic and conglomeratic units within Golconda allochthon

Wallin and Gehrels, 1995, Denudation of Trinity terrane and timing of siliciclastic sedimentation in Yreka terrane

Watkins, 1993, Permian carbonate platform in an island-arc setting, Eastern Klamath terrane

Wells and Waters, 1933, Basic igneous rocks of Roseburg quadrangle

Whitney, 1976, Clay mineralogy of early-stage weathering products of ultramafic bedrock in alpine zones 